\title{
High Efficiency Fossil Power Plant (HEFPP) \\ Conceptualization Program
}

Final Report

Start Date: May 28, 1998

End Date: October 31, 1999

Principal Author: J.L. Justice

March 25, 1999

Contract No. DE-AC26-98FT40356

Submitted by:

M-C Power Corporation

8040 S. Madison Street

Burr Ridge, Illinois 60521-5808 


\section{Disclaimer}

"This report was prepared as an account of work sponsored by an agency of the United States Government. Neither the United States Government nor any agency thereof, nor any of their employees, makes any warranty, express or implied, or assumes any legal liability or responsibility, for the accuracy, completeness, or usefulness of any information, apparatus, product, or process disclosed, or represents that its use would not infringe privately owned rights. Reference herein to any specific commercial product, process, or service by trade name, trademark, manufacturer, or otherwise does not necessarily constitute or imply its endorsement, recommendation, or favoring by the United States Government or any agency thereof. The views and opinions of authors expressed herein do not necessarily state or reflect those of the United States Government or any agency thereof' 


\begin{abstract}
This study confirms the feasibility of a natural gas fueled, $20 \mathrm{MW}$ M-C Power integrated pressurized molten carbonate fuel cell combined in a topping cycle with a gas turbine generator plant. The high efficiency fossil power plant (HEFPP) concept has a 70 percent efficiency on a LHV basis. The study confirms the HEFPP has a cost advantage on a cost of electricity basis over the gas turbine based combined cycle plants in the $20 \mathrm{MW}$ size range. The study also identifies the areas of further development required for the fuel cell, gas turbine generator, cathode blower, inverter, and power module vessel. The HEFPP concept offers an environmentally friendly power plant with minuscule emission levels when compared with the combined cycle power plant.
\end{abstract}


Table of Contents

Disclaimer

Abstract

Table of Contents

List of Graphic Materials

1. Executive Summary

2. Introduction

3. Results and Discussion

A. Concept Verification

1. Design and Development Issues
a. Fuel Cell Stacks
b. Gas Turbine Generator
c. Balance of Plant

2. Confirmation of Design Parameters
a. Fuel Cell
b. Gas Turbine Generator
c. Balance of Plant

3. Optimum Operating Pressure Study

4. Optimum Number of Spare Trains for Each Major Process Area

B. System Definition

1. Process Description

2. Plant Performance Summary

a. Fuel Cell Stacks

b. Turbine Generator

c. Overall Plant

3. Process Flow Diagram

4. Control Concept

a. Fuel Cell

b. Turbine Generator

c. Overall Plant

5. List of Major Equipment

C. Economic Projections

1. Description of Estimate

2. Sources of Cost Data

3. Estimate of Capital and Operating Costs

4. Economic Analysis Results

5. Comparison of Fuel Cell Power Plant with Competing Technology
Page

ii

iii

iv

V

1-1

2-1

3-A-1

3-A-1

3-A-1

3-A-1

3-A-5

3-A-9

3-A-13

3-A-13

3-A-15

3-A-20

3-A-27

3-A-33

3-B-1

3-B-1

3-B-7

3-B-7

3-B-8

3-B-9

3-B-14

3-B-117

3-B-117

3-B-119

3-B-122

3-B-123

3-C-1

3-C-1

3-C-2

3-C-3

3-C-11

3-C-12

4-1

4. Conclusion 


\section{List of Graphics}

Figures

Page

1. Gas Turbine Cycle Efficiency - relative to maximum cycle efficiency

\section{Drawings}

1. B-001

3-B-15

2. B-002

3-B-21

\section{Tables}

1. Major Subsystem Design Parameters and Operating Conditions

Site Elevation - Sea Level

2. Performance Summary Site Elevation - Sea Level SOR

3. Performance Summary Site Elevation - 5,000'

$3-\mathrm{A}-25$

4. Performance Summary Site Elevation - Sea Level EOR

5. Performance Summary

$3-\mathrm{A}-32$

6. Design Specification

$3-\mathrm{B}-5$

7. Major Subsystem Design Parameters and Operating Conditions Site Elevation - Sea Level

8. Performance Summary Site Elevation - Sea Level SOR

9. Performance Summary Site Elevation - 5,000'

10. Performance Summary Site Elevation - Sea Level EOR

11. Material Balance - Full Load, SOR - Sea Level $15^{\circ} \mathrm{C} / 29^{\circ} \mathrm{C}$ Ambient Air

3-B-16

12. Material Balance - Full Load, SOR - 5,000' Elev. $/ 15^{\circ} \mathrm{C} /-29^{\circ} \mathrm{C}$ Ambient Air

13. Material Balance - Full Load EOR - Sea Level $15^{\circ} \mathrm{C} / 49^{\circ} \mathrm{C}(0 \%$ Rel. Humidity) Ambinet Air

14. Material Balance - Full Load SOR - Sea Level $15^{\circ} \mathrm{C} /-29^{\circ} \mathrm{C}$ Ambient Air

15. Material Balance - Full Load SOR - $-5,000$ Elev. $/ 15^{\circ} \mathrm{C} /-29^{\circ} \mathrm{C}$ Ambient Air

16. Material Balance - Full Load EOR - Sea Level $15^{\circ} \mathrm{C} / 49^{\circ} \mathrm{C}(0 \%$ Rel. Humidity) Ambient Air

17. Stream Summary Information Full-Load, SOR - Sea Level $/ 15^{\circ} \mathrm{C}$ Ambient Air

18. Stream Summary Information Full-Load, SOR - Sea Level $/ 20^{\circ} \mathrm{C}$ Ambient Air

19. Stream Summary Information Full-Load, SOR - Sea Level $/ 49^{\circ} \mathrm{C}(0 \%$ Rel. Humidity) Ambient Air

20. Stream Summary Information Full-Load, SOR - Sea Level $/ 49^{\circ} \mathrm{C}(100 \%$ Rel. Humidity) Ambient Air

21. Stream Summary Information Full-Load, SOR -5,000' Elev. $/ 15^{\circ} \mathrm{C}$ Ambient Air $3-\mathrm{B}-63$

22. Stream Summary Information Full-Load, SOR $-5,000^{\circ}$ Elev. $/-20^{\circ} \mathrm{C}$ Ambient Air 3-B-72 


\section{Tables cont.}

23. Stream Summary Information Full-Load, SOR $-5,000^{\prime}$ Elev. $/ 49^{\circ} \mathrm{C}$ ( $0 \%$ Rel. Humidity) Ambient Air

24. Stream Summary Information Full Load, SOR $-5,000^{\prime}$ Elev. $/ 49^{\circ} \mathrm{C}(100 \%$ Rel. Humidity) Ambient Air

25. Stream Summary Information Full-Load, EOR - Sea Level $/ 15^{\circ} \mathrm{C}$ Ambient Air

26. Steam Summary Information Full-Load EOR - Sea Level $/ 49^{\circ} \mathrm{C}$ ( $0 \%$ Rel. Humidity) Ambient Air

28. HEFPP Major Equipment Cost List

29. Electric Power Generation Cost

30. Annual Operating Costs

31. COE-\$/kW-h, NPV Calculation 20 MW MCFC Based HEFPP Facility

32. Combined Cycle Gas Turbine Electric Power Generation Cost

$3-\mathrm{C}-16$

33. Combined Cycle Gas Turbine Annual Operating Costs

$3-\mathrm{C}-17$

34. COE- $\$ / \mathrm{kW}$ h, NPV Calculation $22 \mathrm{MW} \mathrm{CC-GT} \mathrm{Plan}$

$3-\mathrm{C}-18$ 


\section{EXECUTIVE SUMMARY}




\section{EXECUTIVE SUMMARY}

This study shows that Pressurized Molten Carbonate Fuel Cell technology can be combined with gas turbine technology to produce a high efficiency power plant with 70 percent low heating value efficiency when utilizing natural gas as the fuel in the $20 \mathrm{MW}$ plant size. The study has also proven that the high efficiency fossil power plant (HEFPP) concept produces a lower cost of electricity upon comparison with a similar size combined cycle plant. In the specific study case, the HEFPP concept cost to produce electricity was 6.3 cents per $\mathrm{kWh}$ as compared to the 7.1 cents per $\mathrm{kWh}$ for the gas turbine combined cycle case. The HEFPP concept also produces a much more environmentally friendly power plant with very low emissions of $\mathrm{NOx}, \mathrm{CO}_{2}$, and $\mathrm{SOx}$, when compared to the gas turbine combined cycle case.

This study acknowledges that investments of capital and time in the HEFPP components must be made to drive the component costs down and to eliminate or improve specific problem areas. Specific components requiring further investment and development time include fuel cell stacks, gas turbine generator, recycle blower, power module vessel, and inverter. It should be noted that significant work to validate the process concept at smaller scale has already been completed or is in progress based on DOE funding for MC Power's Process Design and Improvement Project under contract DE-FC21$95 \mathrm{MC} 30133$ and the ongoing MCFC power plant testing at Miramar. 


\section{INTRODUCTION}




\section{INTRODUCTION}

M-C Power Corporation was the prime contractor for the High Efficiency Fossil Power Plant concept study with Bechtel National, Inc., Rolls-Royce Allison, and Institute of Gas Technology (IGT) as the subcontractors.

The High Efficiency Fossil Power Plant (HEFPP) proposed concept consists of several integrated molten carbonate fuel cells (MCFC) serving as a topping cycle to a variable speed gas turbine driving an air compressor and electric alternator. The power plant will produce approximately $20 \mathrm{MW}$ of power when natural gas is used as the fuel source. The gas turbine compressor section provides compressed air at a pressure ratio of 6 to the $\mathrm{MCFC}$. The MCFC provides hot exhaust gas for expansion in the gas turbine, which drives both the compressor section and the alternator. DC power from the fuel cells is run through inverters where the voltage is converted. The AC power is elevated to $4160 \mathrm{VAC}$. The power from the gas turbine alternator is directed through a power conditioner whereby the frequency is corrected to $60 \mathrm{~Hz}$ and the voltage is changed to 4160VAC. It should be noted that the design concept for the HEFPP is based on M-C Power's $450 \mathrm{~kW}$ MCFC power plant.

The main goal of the HEFPP study is to have a minimum overall plant efficiency of 70 percent excluding the potential for excess steam generation for cogeneration purposes from the high temperature gas turbine exhaust. Other goals are to achieve low environmental emissions and have high reliability with no major technical barriers for commercialization by the year 2010. An economic goal is to have the HEFPP plant to achieve a reduction by 10 to $20 \%$ for the cost of electricity price below a conventional gas turbine combined cycle plant.

This study identifies the design and development issues associated with the proposed HEFPP, confirms the design parameters of the various plant components, provides the process description and plant performance summary, makes economic projections for the plant capital and operating costs, and establishes the plant life cycle costs and cost of electricity. The HEFPP concept has been compared to a similar size gas fired gas turbine based combined cycle power plant with similar environmental emissions to assess the economic viability of the project. 
3. RESULTS AND DISCUSSION 
3.A. CONCEPT VERIFICATION 


\section{RESULTS AND DISCUSSTION}

\section{A Concept Verification}

This report section addresses the design and development issues and design parameters for the HEFPP concept by looking at the fuel cell, gas turbine generator and the balance of plant. Optimization of the cycle operating pressure and the number of spare trains are also addressed in this section.

\section{A.1. Design and Development Issues}

\section{A.1.a Fuel Cell Stack}

The molten carbonate fuel cell (MCFC) stacks in the High Efficiency Fossil Power Plant (HEFPP) study are the next generation of the full-area commercial-size MCFC stacks. Verification of the new generation has begun at M-C Power's pressurized test facility with a 75 kW demonstration stack at Miramar Marine Corps Air Station near San Diego. The development plan for cell package engineering to meet the required commercialization cost, power density and life goals for the year 2000 to 2006 time frame is in place as part of the present DOE funded Process Design Improvement (PDI) program (DOE Contract No. DE-FC21-95MC30133). The following design and development issues are being considered for successful implementation of the MCFC for the high-efficiency power plants:

\section{Endurance (stack life) under HEFPP operating conditions.}

The projected stack life under HEFPP operating conditions is 40,000 hours. There are no physical laws or technical data that states that this goal is beyond reach and cannot be achieved by $2008-2010$.

The issues limiting stack life include:

(a) $\mathrm{NiO}$ cathode dissolution in the electrolyte and electrical shorting by $\mathrm{Ni}$ deposition in the matrix,

(b) electrolyte loss by corrosion of the separator plate and metal current collectors, and electrolyte loss by evaporation,

(c) matrix ability to retain electrolyte due to change of matrix pore structure and phase composition,

(d) matrix crack-resistance,

(e) separator plate corrosion,

(f) wet-seal corrosion protection and efficiency of sealing.

$\mathrm{NiO}$ cathode dissolution in electrolyte and electrical shorting by $\mathrm{Ni}$ deposition in the matrix

The issue of cathode dissolution and Ni-shorting through the matrix is being addressed by using additives, such as $\mathrm{CaO}$ or $\mathrm{CaCO}_{3}$, to the $\mathrm{Li}-\mathrm{Na}$ carbonate electrolyte. A stabilized cathode also reduces the potential for shorting. The use of $\mathrm{LiNa}$ significantly reduces $\mathrm{NiO}$ cathode 
dissolution. The Dutch experimental data suggests that MCFC stacks can operate between 30,000-50,000 hours before the shorting occurs. An Institute of Gas Technology (IGT) benchscale fuel cell had operated for $>17,000$ hours with no shorting. Additional development work and testing are planned to confirm the stack life can be increased to the 40,000 -hour goal.

\section{Electrolyte losses}

To abate electrolyte loss by corrosion of the separator plate and current collectors, material selection for the cell cathode side is being analyzed and design modifications are being considered. The $310 \mathrm{~S}$ has better corrosion resistance than $316 \mathrm{~L}$; however, the analysis has shown that $310 \mathrm{~S}$ stainless steel consumes more electrolyte for corrosion than $316 \mathrm{~L}$. The purpose of the design modifications is to reduce the metal surface area exposed to electrolyte and, by doing that, to reduce electrolyte losses by corrosion. Considerable reduction of the electrolyte loss by evaporation has already been achieved by changing from $\mathrm{Li}-\mathrm{K}$ to $\mathrm{Li}-\mathrm{Na}$ electrolytes per $\mathrm{M}-\mathrm{C}$ Power and IGT bench scale testing. The $310 \mathrm{~S}$ material will be tested at Miramar in a $75 \mathrm{~kW}$ stack as part of the Process Design Improvement Project.

\section{Matrix pore structure and phase composition change}

The ability of the matrix to retain electrolyte depends on $\mathrm{LiAlO}_{2}$ phase stability and particle growth. It was found that $\alpha-\mathrm{LiAlO}_{2}$ is more stable than $\gamma-\mathrm{LiAlO}_{2}$ at the normal operating temperature of $\sim 650^{\circ} \mathrm{C}$. However, recent $\mathrm{CHI}$ experience has proven that $\gamma-\mathrm{LiAlO}_{2}$ can be stable if very high purity constituents and very small uniform particles are used, which increases stack life to 40,000 hours. For its previous stacks, $\mathrm{M}-\mathrm{C}$ Power has used $\gamma-\mathrm{LiAlO}_{2}$ matrices; but both approaches are being evaluated for future matrix material.

\section{Matrix crack-resistance}

The matrices developed by M-C Power confirmed their ability to withstand multiple thermal cycles. A number of bench-scale cell tests, which have been performed at IGT, showed that cell performance, sealing, as well as matrix integrity were not compromised after 6-8 thermal cycles. Full area fuel cell thermal cycling tests are planned at Miramar as part of the PDI project.

\section{Separator plate corrosion}

Stainless steels $316 \mathrm{~L}$ and $310 \mathrm{~S}$ are the current choices for MCFC separator plate material. The nickel-clad layer is being used for the anode side because $\mathrm{Ni}$ is thermodynamically stable in the anode gas environment. With the $\mathrm{Ni}$-coating protection, the anode side did not show any signs of corrosion attack after several thousand hours of operation. Based on published data [CFC Technology, 1993, V.93-3, p.158], the 0.002" thick Ni-layer may be sufficient for 40,000 -hour operation. Economical considerations require elimination of the Ni-clad layer. M-C Power has been conducting studies of homogeneous materials that could be technically and economically suitable for the separator plate. This effort is ongoing. 


\section{Wet-seal corrosion protection}

The wet-seal area simultaneously experiences reducing and oxidizing environments and requires a special corrosion protection. Aluminization of the stainless steel surface has been generally used for this purpose. M-C Power's plates have been aluminized by Al-spray with following heat-treatment to provide an inter-metallic corrosion-resistant coating. Based on projections of the experimental data [CFC Technology, 1993, Vol.93-3, p.160], the aluminized coating is sufficient for 40,000 -hour operation provided that a consistent quality of coating is maintained. Further development of wet-seal aluminization is planned to improve the quality and to reduce the cost of the process.

\section{Maximum hardware temperature}

Another issue related to stack life is the maximum hardware temperature that is determined by the stack flow geometry. The lower the maximum hardware temperature, the longer stack life. For cross-flow stacks the maximum local hardware temperature is high $\left(>700^{\circ} \mathrm{C}\right)$, especially at a high current density. This issue is being addressed through plate and stack hardware design.

\section{Stack Life Verification Testing}

The required 40,000-hour stack life has to be verified via a comprehensive development and testing program that will encompass further improvement and cost reduction of individual components, cell packages, and small stacks operating under power plant conditions - gas compositions, flows, temperatures, pressures. A part of this program will include testing of full area stacks, $1000 \mathrm{~cm} 2$ and $100 \mathrm{~cm} 2$ stacks at increasing current densities, fuel utilizations and operating pressures.

\section{Stack Design Issues}

The main MCFC stack design improvement issues include the following:

1. Development of a cost-effective, reliable and "simple" clamping system for the commercial design. The prototype clamping system, which will be implemented on M-C Power's $450 \mathrm{~kW}$ demonstration project, will eliminate use of the bellows and the associated bellows control system by use of springs.

2. Development of a cost-effective and "thin" cathode endplate that will improve thermal cyclability and sealing at the top by conforming to the stack. M-C Power is presently working on this problem as part of the PDI program.

3. Development of a commercial-design plenum to provide proper flow conditions at minimum cost and space. The initial designs will be tested in the $450 \mathrm{~kW}$ demonstration project. The plenum will require redesign at the $600 \mathrm{kPa}$ operating pressure as the specific volume of gas is significantly different from the $300 \mathrm{kPa}$ used on the $450 \mathrm{~kW}$ power plant.

4. Development of a commercial-design power-bus that satisfies electrical and mechanical requirements. The prototype will be tested in the $450 \mathrm{~kW}$ demonstration projected under the Process Design \& Improvement Contract. The power bus will 
require rework in the HEFPP project as four stacks will be combined and equipment location and geometries will be different in the $600 \mathrm{kPa}$ power module vessel.

5. Electrical connection of several stacks in series which will raise the total voltage going to the inverter, reduces the inverter cost, improves inverter electrical efficiency, and improves the overall plant efficiency.

Confirmation of predicted performance and endurance at the $600 \mathrm{kPa}$ pressure level will require both bench scale and full cell area testing. With the increase in pressure over the 300 $\mathrm{kPa}$ PDI project, the stack pressure drops (plenum arrangement internal manifolding, and plate spacing) will require review and possible redesign to reach the desired pressure drops. 


\section{A.1.b Gas Turbine Generator}

The 3.8 MW Rolls-Royce Allison gas turbine generator must be designed and developed prior to use in the HEFPP project. Specific issues are addressed individually below:

\section{Direct Drive Alternators (DDA)}

The advantage of the direct drive alternator is that it eliminates the need for a gearbox between the turbo-machinery and the generator that it drives. This, in turn, opens the way to totally oilfree system providing appropriate bearings are used. The best bearing system is considered to be an Active Magnetic Bearing (AMB) configuration.

The DDA is to be run asynchronously such that there is an option to adjust the turbogenerator speed to suit the selected plant power level. It is anticipated that the plant turndown efficiency will be enhanced if the turbogenerator flow can be decreased at low power level (to prevent overcooling of the stack and to diminish the exhaust energy drain). Although this could be achieved to a degree by using variable vanes at a fixed turbine generator speed, asynchronous running offers a physically simpler and more thermodynamically efficient approach.

DDAs have been developed up to about $75 \mathrm{~kW}$ for use with microturbines and individual units have been demonstrated up to approximately $300 \mathrm{~kW}$ but not up to the $3.8 \mathrm{MW}$ level. High speed electric motors, which may be regarded as close mirror images of DDAs have been produced at high power [Drives and Controls magazine July/August 1998 which reports an 8 MW motor with a design speed of 10,000 RPM]. The $3.8 \mathrm{MW}, 11,000$ to 15,000 RPM DDA required for this application must be designed in a manner which is compatible with the overall plant control scheme and, to this extent a new design task is created. Although the solution will be new in detail, it will represent a focusing of available technologies rather than a step into the unknown.

The power conditioning system is anticipated to take high frequency AC from the DDA, rectify it, and then convert it to $60 \mathrm{~Hz}$ in a converter dedicated to the turbogenerator. The mechanical integration of the compressor, turbine and DDA will be much facilitated by the use of AMBs, because they permit tuning of equivalent support stiffness to tune out potential vibration modes.

\section{Power Conditioning (Converter)}

Converter design choices tend to be influenced by the best solid state electronic component values currently available. Presently, for instance, $250 \mathrm{~kW}$ is a good modular size, which is likely to increase. Influenced by the different control requirements of the fuel cell stack and turbogenerator power loops, it is expected that the turbogenerator converter will be kept separate from the inverter or inverter array handling the fuel cell stack power output. The hybrid fuel cell power plant is likely to become a driving force in the advancement of cost effective large power conditioners (converters).

The present capacity of the Insulated Gate Bipolar Transistors (IGBTs) is a limiting factor to a single unit power conditioner. Other technologies such as gate turnoff thyristors (GTOs) are 
available but have inherent problems of lower efficiency and slower switching speeds when compared to the IGBT technology. Other emerging technologies, which require further study and development, include the MOS Turn-off Thyristors (MTOs) and the Integrated Gate Comutating Thyristor (IGCTs).

By 2010, the new IEEE electric grid interconnect standard (IEEE P1547) for distributed generation (currently in development) will likely require some modifications to the power conditioner in terms of additional protection and control requirements. It is envisioned the IEEE standard will require sweeping changes throughout the power conditioner industry as the industry moves toward a standard power conditioner configuration and away from each customer or contract having specific site performance requirements. The IEEE standard should help reduce the cost of the inverter performance and programming by minimizing the per contract engineering costs. At present, no power conditioner test protocol exists for testing the $3.8 \mathrm{MW}$ power conditioner. In addition, no manufacturer or third party testing organization is set up to full load test a power conditioner of this size. A test protocol and suitable test lab will have to be developed to accommodate the large power conditioner. Acceptance testing of the power conditioner will be critical to utility acceptance of the plant for reliability and safety reasons.

Power conditioner electrical efficiency presently at 95 percent must be improved to the 97.5 percent to improve the gas turbine generator output and the overall plant electrical efficiency.

\section{Active Magnetic Bearings}

Rolls-Royce Allison has proposed using magnetic bearings on the plant gas turbine generator. Magnetic bearings have several advantages, which include the following:

1. Long bearing life

2. Bearings are self-correcting to out of balance loads, which may arise through wear and tear or deposition.

3. No lubrication required (eliminates the need and weight of an entire lubrication system)

4. Reduced friction losses, as the only friction at bearings is air. (Reduced friction yields a more efficient machine)

5. The gas turbine is more reliable as the entire lubrication system has been eliminated, which can cause failure.

6. Bearings have inherent ability to reduce noise and vibration caused by rotor imbalance.

Active magnetic bearings (AMBs) with their associated control system inherently offers on-line monitoring and control of bearing forces and rotor displacements allowing early detection of faults. Further control system development work will be required in the programming and controls area to electronically locate the rotor position and to generate the current required for the magnetic bearings.

The control and stabilization of active magnetic bearings is now well understood and the gas turbine generator components can readily be designed to achieve good bearing performance without resort to new materials technology. This is because the bearings can be situated in a reasonably cool environment between $422^{\circ} \mathrm{K}$ and $588^{\circ} \mathrm{K}$, which is compatible with normal 
electromagnet materials. AMBs are not yet widely in use, so some learning experience must be anticipated during the early embodiment.

\section{Combustor}

A low risk conventional combustor will be used in the firing of the Rolls-Royce Allison gas turbine generator. Several considerations affect the design choices for the combustor which appear below:

1. Because the combustor will be fueled for a short time, it should not be required to have ultralow emissions. At maximum temperature rise, the $\mathrm{NO}_{x}$ emissions will be in the $100-150 \mathrm{ppm}$ range but will decrease as the plant heats up.

2. As the fuel cells rise in temperature, the combustor delivery temperature is held constant requiring less fuel to burn. Combustor stability is required over a substantial range of fuel flow.

3. To avoid complicating the hot ducting, the combustor must remain in the main flow path even though it is not functioning. The pressure drop across the combustor must be minimized.

4. The combustor and associated ducting will have to be insulated in a thermal blanket to avoid overheating adjacent plant equipment.

Rolls-Royce Allison has recommended that a cylindrical three liner type combustor be used. The design point temperature rise is 866 to $921^{\circ} \mathrm{K}$ based on plant startup conditions. The normal capability of a single liner system is to turn down by stable means to approximately one quarter of its design temperature rise $\left(135-149^{\circ} \mathrm{K}\right)$. The provision of three liners allows individual liners to be shut down, such that while the last operating liner is still producing a $167^{\circ} \mathrm{K}$ rise, the whole flow average rise is only $55.5^{\circ} \mathrm{K}$, permitting a smoother transition from fired to unfired during startup. If it is determined that a larger step change is acceptable, then the system can be simplified to a single liner design. An alternate for further study is to utilize a catalytic element in the combustor in addition to multiple liner operation.

\section{Gas Turbine Generator Control System}

The gas turbine generator control system would be used to startup the gas turbine with a start signal from the plant control system. Once the gas turbine has been started, the fuel cell heated, and the combustor switched off, the gas turbine control system fuel control logic would become dormant. The gas turbine control system would control turbine speed and monitor turbine generator supervisory control. The plant control system through the turbine generator programmable logic controller (PLC) would take over the operation of the gas turbine generator to match the overall plant process requirements of the turbine compressor and expander sections. The coordination between the gas turbine controls and the plant control system still requires further development and understanding between Rolls-Royce Allison, M-C Power and Bechtel National.

Modeling work will also be required to determine the load following, load shedding and turndown of the generator and power conditioner. The response to electrical system transients 
such as loss of electric grid, ground faults in single phase or neutral, synchronization, and switch to island mode operation must be studied in more detail. Schemes for voltage control, current control, frequency control, power factor control and switching to and from voltage and current control modes quickly'must also be studied.

Once the plant has reached the steady state performance, positive control of the turbogenerator running point will be primarily maintained in an asynchronous system by altering the DDA load characteristics. This requirement affects the electrical design of the generator and the associated power conditioning and electrical protection systems. The integration process is expected to require significant development time and capital. 


\section{A.1.c Balance of Plant}

Much of the balance of plant (BOP) equipment (excluding the fuel cell and the gas turbine generator) has no design or development issues because the products available are considered to be mature. Specific pieces of equipment which will require additional design and development prior to use in the $-20 \mathrm{MW}$ high efficiency pressurized molten carbonate fuel cell power plant appear below:

\section{Recycle Blowers}

At approximately $610 \mathrm{kPa}$ operating pressure, only a limited number of blower manufacturers have the knowledge base and experience to properly design the recycle blower. The blower operates at a low pressure ratio, high temperature, and moderate pressure. The design issues resulting from the design constraints are as follows:

Shaft seals-The shaft seals must be designed to keep the higher pressure cathode gas from leaking out to atmosphere. Design, material selection, and endurance testing for design confirmation will be required.

Bearing design- The bearing design must accommodate the blower rotor high temperatures and the associated shaft thermal growth. Confirmation of the bearing and shaft design prior to the commercial unit will be required by shop testing of any proposed solution.

Materials of Construction- The materials selected for the blower housing, impeller, and shaft must be designed to prevent high temperature surface corrosion. This may be accomplished by the use of high temperature base materials or with protective spray coatings over a less costly base material. Endurance testing of the proposed materials must be verified by testing prior to installation in a commercial fuel cell power plant.

\section{Power Module Vessel}

Each power module vessel contains four (4) molten carbonate fuel cell stacks, four (4) reformer assemblies, and miscellaneous piping. Some of the design and development issues associated with the Power Module Vessel include the following:

Vessel Design-The design must accommodate the removal and reinstallation of the individual reformers and fuel cell stacks. Other requirements include the access requirements for maintenance and transportation of the vessel with equipment installed subject to weight and dimensional restrictions of land-based transportation. Wind loading, seismic loading, and transportation loading (lifting vessel assembly onto and from vehicle, and vessel stiffness to road potholes) design conditions must also be considered in the vessel design. Power module assembly methods and sequences must also be modeled and developed by the plant module fabricator prior to vessel fabrication commencement. A removal scheme for each fuel cell and reformer with special tooling required must be modeled and procedure developed prior to vessel fabrication. Nozzle orientations and allowable stresses must be studied and coordinated with both vessel interior and exterior piping. Electrical power and grounding connections to the power 
module components must be routed and designed to the ANSI/NFPA 70, ANSI C2, IEEE 80, and IEEE 142. The instrumentation must be designed to take the high internal vessel temperature and penetrate through the pressure vessel wall without leaks. A supporting vessel structure such as saddles, which controls the vessel thermal growth, must also be developed. With the vessel in operation containing both natural gas and hydrogen, a blast analysis study must be completed to specify and locate the appropriate blast pressure relieving devices. M-C Power will perform most of these tasks on the $450 \mathrm{~kW}$ demonstration plant power module vessel. The PDI $450 \mathrm{~kW}$ power module vessel will operate at $300 \mathrm{kPa}$ pressure, which results in larger diameter vessel and piping than the HEFPP vessel. Lessons learned will be implemented in the HEFPP power module vessel.

Vessel Insulation Design- The vessel insulation must be studied to allow acceptable heat loss during plant operation at the lowest and highest ambient temperature. The insulation should also be designed for personnel protection from burns due to hot insulation or jacketing, where accessible by plant personnel. The insulation will also be designed to protect the vessel internal metal surfaces from condensation and to allow the use of carbon steel pressure vessel materials.

Piping design- The power module piping design must be studied to eliminate the use of control valves inside the pressure vessel. Manual valve usage inside the pressure vessel will be studied to minimize the number of valves. Pipe thermal expansion inside the vessel will be studied to eliminate the need for expensive expansion joints. High temperature, low-pressure-drop check valves located inside the hot pressure vessel will have to be developed and tested to keep the cathode blower power consumption low. In general the piping will be smaller but heavier wall for the HEFPP $600 \mathrm{kPa}$ operating pressure when compared with the PDI $450 \mathrm{~kW}$ piping.

\section{Inverter}

The initial design plan is for one inverter to be provided for each power module. Four fuel cells in one common pressure vessel would feed one inverter. The fuel cells will be connected electrically in series. The inverter takes the DC power from the fuel cells and then boosts the DC voltage. Initial thoughts were to have the higher voltage DC power inverted to AC power at nominally $480 \mathrm{VAC}$. With 9 inverters and a net expected output from the inverters to exceed 17 MW, the electric bus connecting the inverters together becomes large due to the high current handling requirements. The $480 \mathrm{VAC}$ inverter output will have to be transformed up to a higher voltage to minimize large bus duct costs and grid connection costs. The present scheme is to have the inverter output voltage changed from $480 \mathrm{VAC}$ to $4160 \mathrm{VAC}$. A study to determine the most economical bus and type of step-up transformer will have to be completed in the preliminary engineering phases. With the 9 inverters planned, a master synchronization and paralleling scheme for connecting the individual inverters to the grid and to the turbine generator power conditioner (converter) for startup and shutdown of the plant must be developed. The plant electrical islanding scheme and reconnection scheme must also be developed, which will allow the plant to operate in island mode and then synchronize with the grid without dropping load. The synchronization of the plant must occur within a very few cycles. 
A study to determine the appropriate emerging inverter technology (Integrated Gate Commutating Thyristors (IGCTs), Insulated Gate Bipolar Transistors (IGBTs), MOS Turn-off Thyristors (MTOs) or Gate Turnoff Thyristors (GTOs)) prior to order placement will be required. In the study, efficiency, cost, footprint size, voltage capacity, current capacity, additional auxiliary equipment/system requirements, and switching speed will be evaluated to select the best available technology. An optimization study will also be required to minimize the number of inverters. A limiting factor for the optimization study will be the maximum $\mathrm{AC}$ voltage the selected inverter technology can handle in the high frequency pulse width modulation mode. The pulse width modulation (PWM) technology may be a limiting factor as the maximum rating of present PWM technology is 690 VAC. It is anticipated that by 2003 , IGBTs will be available to handle up to $1200 \mathrm{VAC}$ in the pulse width modulation mode.

The present inverter technology in the size range required for the high efficiency power plant yields 95 percent electrical efficiency. Further developments to improve the efficiency to 97 to 98 percent are required. The most significant efficiency improvement may come from the use of trench type IGBTs, which will cut the conduction losses by 50 percent. Another improvement may come from the use of advanced pulse width modulation (PWM) generation algorithms. Implementation of the new algorithms may reduce the IGBT switching losses by approximately 30 percent without sacrificing bridge performance characteristics. Higher grade magnetic materials can be used in the reactors and chokes to reduce the iron losses or reduce the copper losses via shorter mean turn lengths. Two tradeoffs for the higher grade magnetic materials include higher material and component fabrication costs and reduction in the number of available core suppliers.

Fuel cell currents exceeding 1500 ADC present a unique design challenge for the inverter. The bus bar and cable losses generated at this current level are significant and can be difficult to control. Methods to reduce the losses include a) use of less resistive materials, b) use of broader cross-sections, and c) shorter circuit lengths. All of the above methods will be employed to some extent to repackage the inverter and improve the overall electrical efficiency.

By 2010, the new IEEE P1547 Interconnection standard for distributed generation (currently in development) will probably require modifications to the inverter in terms of additional protection and control requirements. At present no standard exists to test the inverters of this size. In addition, no manufacturer has the in-house testing facilities to perform a full load test of the inverters envisioned. Acceptance testing of inverters will be critical to obtaining electric utility acceptance of the plant for reliability and safety reasons. Development of a test protocol and test facility either at the manufacturer or a third party is required.

Decisions on whether the turbine generator power conditioner or the fuel cell inverter will have the master synchronizer to the electric grid must be made. Initial thoughts on this matter include that the turbine generator power conditioner will be the master as it is the first piece of equipment to start and last to operate under normal conditions. Development of the synchronization scheme requires further work. 


\section{Reformer}

The reformer will also require some development work primarily due to the change in pressure from $300 \mathrm{kPa}$ (used on the PDI project) to the $600 \mathrm{kPa}$ HEFPP operating pressure.

Ishikawajima-Harima Heavy Industries (IHI) has developed a reformer for $1 \mathrm{mPa}$ operation for Japan MCFC projects and $300 \mathrm{kPa}$ operation for Miramar. Operation at $600 \mathrm{kPa}$ will require changes in the flow distribution path. Specific areas of change include piping (where pipe size will get smaller due to lower specific volume but pressure will require thicker pipe materials) and manifolding /plate spacing (where manifolds and plate spacing should get smaller due to lower specific volume). The reformer at $600 \mathrm{kPa}$ operating pressure will also require some testing to confirm performance.

The HEFPP goal for reformer catalyst replacement is 10 years. IHI will develop and test their catalyst to obtain $40,000 \mathrm{HR}$ life as part of the PDI project. Catalyst life is dependent on the amount of catalyst deposited per unit area on the reformer plates and the total plate area in the reformer. Some additional catalyst life development work will be required by IHI for the HEFPP project. 


\section{A.2. Confirmation of Design Parameters}

\section{A.2.a Fuel Cell}

The MCFC stacks will be designed to operate at the following conditions for the HEFPP study:

s. Pressure $(\mathrm{kPa})$

Fuel utilization (per pass, \%)

605 ( 6 atm)

Current density $\left(\mathrm{mA} / \mathrm{cm}^{2}\right)$

80.4

Average cell voltage $(\mathrm{mV})$

758 (at the beginning of life).

When adjusted for operating conditions, this performance is close to the performance that has been achieved in bench-scale fuel cells at IGT and M-C Power. For example, fuel cell IM9705, tested at IGT for approximately 5,000 hours, had a voltage of $730 \mathrm{mV}$ at $200 \mathrm{~mA} / \mathrm{cm}^{2}$ at 303.9 $\mathrm{kPa}(3 \mathrm{~atm})$ and $75 \%$ fuel utilization at the onset of the test. Pressure was increased from 303.9 $\mathrm{kPa}$ to $605 \mathrm{kPa}$, which increased cell voltage by 35 to $40 \mathrm{mV}$; a fuel utilization increase from 75 to $80 \%$ reduced the voltage by $7-10 \mathrm{mV}$. Hence, cell voltage at the HEFPP conditions would be approximately $760 \mathrm{mV}$. M-C Power's fuel cell performance model also predicted that the performance required for MCFC stacks at the HEFPP is achievable.

Based on experimental data, model predictions, other published data, and M-C Power's performance improvement plan, this level of performance for MCFC stacks is obtainable.

The challenge is to achieve and maintain this level of performance at the full-area commercialsize stacks.

The following issues related to performance improvement are being addressed presently as part of the DOE funded PDI program:

1. Optimization of component pore matching and electrolyte distribution among components. Implementation of better pore matching will improve performance by reducing anode and cathode polarization. Adjusting the pore-size distributions and the wetting properties of the electrodes will improve pore matching.

2. Optimization of the cathode thickness and its porous structure. Because of the higher $\mathrm{Li} / \mathrm{Na}$ ionic conductivity, the effective thickness of the cathode with $\mathrm{Li} / \mathrm{Na}$ electrolyte is higher than that of a cathode operating with $\mathrm{Li} / \mathrm{K}$ electrolyte. Increasing cathode thickness and increasing external agglomerate surface will improve cathode performance. Optimizing the cathode oxidation/lithiation reaction will result in $20-30 \mathrm{mV}$ performance improvement.

3. Optimization of electrolyte composition. Comparison with the-state-of-the-art cell performance shows that the cell performance at $160 \mathrm{~mA} / \mathrm{cm}^{2}$ can be improved by $20-25 \mathrm{mV}$ simply by the change of electrolyte composition. Another advantage of this alternate electrolyte is a reduced sensitivity of cell performance to the operating temperature, which results in a higher stack output and a lower stack maximum temperature. 
4. Improvement of component manufacturing tolerances will result in: (a) more uniform flow distribution among cells and will allow the stacks to operate at $80+\%$ fuel utilization per pass and (b) uniform contact pressure distribution over the active area with reduced stack internal resistance.

5. An advanced plate design to reduce cost, ensure $100 \%$ sealing, lower electrolyte losses for corrosion, and improve uniformity of flow and pressure distribution.

The full-area commercial size stack performance will be verified via a comprehensive testing program that includes testing of $100-\mathrm{cm}^{2}, 1000-\mathrm{cm}^{2}$, along with full-area cells and stacks. 


\section{A.2.b Gas Turbine Generator}

Rolls-Royce Allison has investigated the critical design parameters associated with a 6.0 pressure ratio $3.8 \mathrm{MW}$ class gas turbine-generator. Specific design parameters are addressed individually below:

\section{Compressor}

Up to a pressure ratio of approximately 6 , axial and radial machines give similar performance between inlet and diffuser exit (at 0.15 Mach number). In the study analysis, a seven stage axial compressor was 0.6 percent more efficient than a single stage radial compressor. Above this pressure ratio, the radial compressor efficiency deteriorates when compared to the axial compressor due to rising Mach number effects in the single radial stage. The maximum radial stage pressure efficiency is normally limited by metal strength properties (maximum pressure ratio of 6.5 for steel and 8 to 9 for titanium). Radial compressors offer a large reduction in number of parts and cost for a given pressure ratio. At a pressure ratio of 6 , the most cost effective compressor design results in a single steel stage radial compressor. It should be noted that the radial compressors have not been produced in aeroderivative gas turbines for many years. The radial compressor will have a large scroll diameter approaching 1.5 meters. In developing the radial compressor design, the following design parameters were used:

1. Inlet hub/tip radius ratio will be set to 0.4 to avoid extreme airfoil geometry (also allows for bearing if desired)

2. Inlet tip radius is designed to avoid exceeding a 1.0 inlet Mach number relative to the blades.

3. The rotor tip radius is adequate to generate the design pressure ratio at appropriate loading.

\section{Turbine}

In the HEFPP, turbine gas flow will be delivered from the fuel cell to the gas turbine generator by a circular pipe. Hot process gas from the fuel cell is transferred to the axial turbine inlet through a carefully shaped volute in which the design and fabrication processes have been used many times by Roll-Royce Allison. Delivery of gas from the volute is designed to be at a fixed swirl and axial velocity components to maintain a constant nozzle guide vane entry angle. The tangential component of the velocity serves to partially offload the vanes. By taking the principle too far, the resultant will lead to large volute velocity and potential wall scrubbing losses. It is therefore desirable and efficient to retain a row of guide vanes for the turbine section.

The turbine inlet temperature of $704^{\circ} \mathrm{C}$ is low enough to allow the use of low cost materials and allows elimination of turbine wall cooling temperatures.

The single shaft design turbine generator imposes a lower speed limit than preferred for the compressor. The reasons for this are as follows:

1. The volumetric flow leaving the turbine is 2 to 2.5 times larger than that entering the compressor because the exhaust temperature is higher. (If a stage hub/tip radius ratio of 0.5 is 
used, the last turbine blade tip radius is approximately 1.5 times that of the first compressor blade which gives a correspondingly higher tip speed.)

2. The power turbine tips normally have to carry shrouds for maximum efficiency.

3. The turbine blades are hotter.

The axial turbine design criteria used are as follows:

1. Minimize the turbine stages required for each duty.

2. Keep the stages at moderate internal Mach number and loading to retain high efficiency.

3. The final stage exit area should yield an axial Mach number of 0.35 . Diffuser losses should be kept at no greater than 40 percent of dynamic head, which yields a maximum 3 percent total pressure loss.

4. The highest rotational speed should be selected based on the selected material properties.

5. The exit hub/tip radius ratio should be kept between 0.5 and 0.6 to avoid local aerodynamic problems and provide sufficient space for structure. (Note: this now fixes the last stage hub and tip radius.)

6. Airfoils with high aspect ratio should be used to give good efficiency and low shroud stress. The aspect ratio should also be low enough to limit the blade count (cost) and avoid excessively thin sections or steep annulus angle. This criteria determines the stage axial lengths.

At a pressure ratio of 6 , it was found that the preferred design RPM for a single stage radial compressor of 13,200 was acceptable when paired with the maximum desired value of the axial turbine. An axial compressor does not offer a significant efficiency advantage for this cycle.

For higher pressure ratio cycles, the tip speed of the radial turbine stage has to be increased (approximately $20 \%$ for a 10 pressure ratio machine) and this moves it into a region where it experiences shock losses. More efficient units can be created using either all axial or hybrid axicentrifugal multistage designs. In order to keep the minimum number of stages, relatively high speed is still required. The speed limiting feature in a single shaft machine is normally the last stage turbine blade hub radial stress. The level of stress can be shown to be fixed by the blade swept area and the RPM. The swept area is set by the air flow amount, its exit temperature, and the requirement for an axial Mach number not exceeding 0.35 .

For cycle options above 6 pressure ratio, it was found that single shaft configuration RPM is limited by turbine last stage stresses. This is just acceptable for a 10 pressure ratio radial compressor of lower efficiency (due to shock losses), but leads to the need for more stages in a more efficient axial or axi-centrifugal machine. Without RPM compromise, a (3 stage axial +1 stage radial) hybrid machine is acceptable for 10 pressure ratio, but, when slowed to turbineacceptable speed, ( 6 axial stages +1 radial stage) is required. Although this represents a cost penalty to a single.shaft configuration, the six axial stages/1 radial stage configuration remains the preferred scheme because of its merits of flow control for power turndown and resistance to load shed overspeed. In addition, pure axial compressors of appropriate speed are already in production, offering cost-effective solutions for a larger size fuel cell plant.

Given that the turbines are running near to the stress limited speed, the number of stages can be minimized. Two stages are necessary for the 6 pressure tatio cycle and three stages are required 
for the 10 and 14 pressure ratio cycles respectively. It is highly unlikely that a low cost single stage radial turbine would give good results in the 6 pressure ratio cycle (at only $977 \mathrm{R}$ inlet temperature, the loading would be greater than optimum) and would be unsatisfactory for the higher pressure ratio cases.

All the axial turbines proposed for the three pressure ratio levels are predicted to yield efficiency between 91 and 92 percent.

\section{Alternator}

Several options were considered for the alternator including the following:

1. Compressor, turbine, and asynchronous alternator on a single high speed shaft.

2. Compressor and turbine on one shaft with a gearbox driving an asynchronous alternator at 6000 RPM

3. Compressor and drive turbine on one shaft. Power turbine and asynchronous alternator on a second somewhat slower shaft.

4. The compressor and turbine on one shaft with a gearbox driving a conventional synchronous alternator at synchronous speed.

5. Turbine and compressor on separate shafts running at their individual best speeds geared to a - synchronous alternator at synchronous speed.

In the first three options, the asynchronous generator would have to be connected to a power conditioner to produce the desired $60 \mathrm{~Hz}$ power. The power conditioner has losses associated with the conversion of high frequency power to $60 \mathrm{~Hz}$ power of 3 to 4 percent. In options three and four, the generator is synchronous and operates at $60 \mathrm{~Hz}$ power, but has the additional gearbox losses, which will reduce the overall turbine generator efficiency by 3 to 4 percent. The geared units also require a lubrication system to keep them operating properly, which may be eliminated with a single common shaft turbine/compressor/asynchronous alternator utilizing magnetic bearings.

The options were also evaluated economically in terms of first cost. The economic choice was the compressor, turbine, and asynchronous alternator on a common shaft option, as the assembly was the lightest of all the options. The geared options have additional weight and cost associated with the gearbox, lubrication system, and the generator. Reductions in speed, force the turbine, compressor, and generator to become larger.

Option 1 has some drawbacks in that the direct drive alternator in the $3.8 \mathrm{MW}$ size range must be scaled up from existing technology presently at the $75 \mathrm{~kW}$ level or derived from the high speed motor technology. For more detailed information, please refer to the Design and Development Section 3.A.1.B. 


\section{Power Conditioner}

With the direct drive alternator, a power conditioner or inverter must be used to convert the high frequency $\mathrm{AC}$ power to $\mathrm{DC}$ power and then back to $60 \mathrm{~Hz} \mathrm{AC}$ power. Several technologies exist or are in development such as insulated gate bipolar transistor (IGBT), gate turn-off thyristor (GTO), MOS turnoff thyristor (MTO), and integrated gate comutating thyristor (IGCT). The IGBTs are limited to approximately $250 \mathrm{~kW}$ single unit size but can have several units placed in parallel on each of three phases to meet the desired power output. The largest paralleled power conditioner in use today is $1.5 \mathrm{MW}$ in capacity used in windmill applications. GTOs may also be used but suffer from slower switching speed and lower efficiency when compared to the IGBT technology. GTOs allow higher current and voltage to be used when compared to the IGBT technology. MTO and IGCT are still being developed but hold promise as the technology of the future. For further discussion, please refer to the Design and Development Issue Section 3.A.1.B.

\section{Magnetic Bearings}

Active magnetic bearings (AMBs) have been selected by Rolls-Royce Allison for use on the proposed gas turbine generator. The AMBs feature reduced friction losses, long bearing life, self correction to out of balance loads, noise reduction, and require no lubrication when compared to conventional lubricated bearings. AMBs are well understood, but will require some development work in the programming and controls required to electronically locate the rotor position and to generate the currents required for the magnetic bearings. For more information, please refer to . the Design and Development Issue Section 3.A.1.B.

\section{Combustor}

In regular aero-derivative turbine generator practice, a 4 percent pressure loss from the compressor diffuser outlet to turbine inlet is required to serve the following purposes:

1. To drive the high velocity dilution air jet streams into the final combustion zones to ensure complete combustion and provide proper mixing within a short length.

2. To ensure that the cooling flow passed to the first turbine blade row is at a higher pressure than the very hot gases impinging on the turbine blade leading edge. This permits the formation of leading edge cooling films on the blade.

With the molten carbonate fuel cell power plant, the turbine generator combustor is different as follows:

1. There is more space for mixing.

2. There is no need to cool the turbine blades as operating temperatures of approximately $700 \mathrm{C}$ are expected which is well below the much higher conventional temperature aeroderivative combustors.

3. The combustor is used only unit startups and transients but most of the pressure losses are always present when not in operation.

4. Weight and operating volume do not have to be minimized.

5. No requirement for very high wall temperatures or cooling air. 
. The preliminary sizing of the combustor components yields a low velocity unit of around 2 feet diameter burning zone and approximately 5 feet length. This combination gives an unfired pressure loss of 1.5 to 2 percent. The parameters mentioned above place the combustor well within the range of conventional duct burner technology. 


\section{A.2.c Balance of Plant}

The next tasks are to establish the equipment design parameters and to select the process operating conditions. Equipment manufacturers provided the equipment design parameters. Table 1 lists the equipment design parameters and operating conditions for the major subsystems.

The selection of operating conditions is based on achieving the highest natural-gas-conversion efficiency for the plant. The following high-efficiency prerequisites directed the processsimulation search for the optimum operating conditions:

口 high conversion of natural gas to $\mathrm{H}_{2}$-rich fuel

a high conversion of $\mathrm{H}_{2}$ fuel to electricity in the $\mathrm{MCFC}$

a high conversion efficiency for $\mathrm{H}_{2}$ chemical energy to electrical energy

a minimize fuel combustion

a high efficiency bottoming cycle

The key operating conditions are listed in the following Table:

\begin{tabular}{|c|c|}
\hline \multicolumn{2}{|c|}{ Full-Load, Start of Run (SOR) Operation $-15^{\circ} \mathrm{C}$ Ambient Air, Sea Level } \\
\hline System Pressure & $610 \mathrm{kPa}$ \\
\hline Steam Temperature & $536^{\circ} \mathrm{K}$ \\
\hline Anode-Recycle Flow, weight ratio & $3: 1$ \\
\hline Steam:HC-Carbon, mole ratio & 4.7:1 \\
\hline Reformer-Inlet Temperature & $799^{\circ} \mathrm{K}$ \\
\hline Reformer Outlet Temperature & $1,061^{\circ} \mathrm{K}$ \\
\hline Anode Inlet Temperature & $950^{\circ} \mathrm{K}$ \\
\hline Cathode Inlet Temperature & $978^{\circ} \mathrm{K}$ \\
\hline
\end{tabular}

\section{Selection of Optimum Operating Conditions}

The effects of key-equipment operating conditions on equipment performance and the naturalgas-conversion efficiency are discussed below.

\section{System Pressure}

The effect of system operating pressure on plant performance is discussed in Section 3.A.3.

\section{Steam Temperature}

Increasing the steam temperature results in a slight increase in power output from the gas-turbine generator - just over $1 \%$ increase for the steam temperature range $480-560^{\circ} \mathrm{K}$. However, any increase in superheat is at the expense of steam flow (since steam is generated in a non-fired heat recovery steam generator (HRSG) unit), and reducing steam flow affects methane conversion in the reformer, leading to lower overall efficiency. 


\section{Steam Flow Rate}

The steam flow rate to the reformer is an important determinant of the natural gas conversion. This variable plays an important role in determining the natural-gas-conversion efficiency.

The steam flow rate must be above the minimum needed to prevent carbon formation in the reformer and provide a safe margin to carbon formation in the anode. For this design, the steam flow rate is the maximum steam flow that can be generated, at $900 \mathrm{kPa}$ and $536^{\circ} \mathrm{K}$, from the gas turbine exhaust, without fuel firing.

As mentioned above, higher methane slip from the reformer results in more fuel combustion in the reformer combustor. When there is sufficient $\mathrm{H}_{2}$ and $\mathrm{CO}$ in the anode exhaust to provide the reformer duty, the combustion of residual methane serves no other purpose than participating in the gas turbine power cycle. Therefore, under these circumstances, residual methane lowers the overall natural-gas-conversion efficiency, and must be minimized.

The steam flow rate also determines the quantity of anode recycle to the reformer.

\section{Reforming Temperature}

High reforming temperatures - i) increase methane conversion, ii) require more residual fuel in the anode exhaust to meet the reforming heat duty (lower plant efficiencies), and iii) requires more expensive materials of construction. The operating temperature is selected by careful consideration of the materials of construction and the values for other process variables affecting methane conversion (pressure, steam flow rate).

For this design, the low operating temperature is offset by high steam flow to the reformer and low operating pressure. The low reforming temperature means that the reformer can be fabricated from stainless steel.

\section{Anode Recycle}

Anode recycle improves flow distribution in the anode, facilitates thermal management, and lowers per-pass fuel utilization in the anode compartment. By introducing the recycle stream upstream of the reformer, the additional water content in the recycle gas helps with the conversion of natural gas to hydrogen-rich fuel.

Anode recycle improves the basic design concept in three important process areas. First, as mentioned, recycling exhaust gas from the anode compartment increases the amount of steam flowing to the reformer. Second, recycling anode exhaust results in an increase in the quantity of hydrogen entering the anode compartment. Therefore, for a fixed fuel conversion, the per-pass fuel utilization is lower. Third, anode recycle helps with the thermal management of the stack.

Higher concentrations of $\mathrm{CO}_{2}$ and $\mathrm{H}_{2} \mathrm{O}$ in the anode feed, as a result of recycling anode exhaust, should lower the stack operating voltage - through the Nernst term in the reversible cell potential equation. However, for the same high fuel conversion without anode recycle, the severely depleted $\mathrm{H}_{2}$ concentration at the anode exhaust lowers the exit reversible potential significantly. 
Since electrodes are iso-potential surfaces, the cell potential, for co-flow designs, is set by its exhaust value.

For the same fuel conversion, the per-pass fuel utilization increases from $80 \%$ with recycle, to $94 \%$ without recycle. To maintain $80 \%$ fuel utilization without anode recycle, the steam flow to reformer has to be increased. Raising additional steam means fuel has to be fired either in the turbine combustor or in the HRSG unit. Raising the additional steam lowers the natural-gasconversion efficiency from $70 \%$ to $63 \%$.

Increasing the reformer outlet temperature from $1,060^{\circ} \mathrm{K}$ to $1,117^{\circ} \mathrm{K}$, in an attempt to increase the methane conversion at reduced steam addition, lowers the efficiency to $61 \%$.

The amount of anode recycle is set by the pre-reformer temperature limitation. Increasing the recycle-to-steam flow weight ratio beyond 3:1 causes the temperature to exceed the pre-reformer catalyst maximum operating temperature.

\section{Anode Inlet Temperature}

The anode feed gas must be hot enough to keep the electrolyte in a molten state. The anode feed gas temperature must be above the Boudouard carbon formation temperature.

\section{Cathode Inlet Temperature}

Like anode feed gas, the cathode feed gas temperature must be sufficient to keep the electrolyte in a molten state.

\section{Cathode Outlet Temperature}

Stack cooling, by an external, gas recycle around the cathode, is responsible for the main auxiliary power demand. Recycle flow, and hence recycle blower horsepower, is minimized by operating between the minimum inlet temperature of $866^{\circ} \mathrm{K}$ and the maximum outlet temperature of $978^{\circ} \mathrm{K}$.

High operating temperatures are needed to achieve lower electrolyte conductivity, which minimizes Ohmic resistance losses and consequent heat generation.

\section{Vessel Heat Loss}

The power module vessel is insulated to minimize heat loss. The argument for minimizing heat loss was made above. 
TABLE 1

Major Subsystem

Design Parameters and Operating Conditions

Site Elevation-Sea Level

\begin{abstract}
Fuel Processor - Reformer
Steam:Hydrocarbon ratio

Steam:Total Carbon ratio

Operating Pressure, $\mathrm{kPa}$

Exit Temperature, $\mathrm{K}$

Process Duty, kJ/h

Number of Units
\end{abstract}

\section{Fuel Cell Stack Design}

Operating Pressure, $\mathrm{kPa}$

Current Density, $\mathrm{mA} / \mathrm{cm} 2$

Cell Voltage, $\mathrm{mV}$

Power Density, $\mathrm{kW} / \mathrm{m} 2$

Fuel Utilization - per pass, \%

Fuel Litilization - overall, \%

Number of Stacks Required

\section{Inverter Design}

Input Voltage, Volts

Input Current, Amps DC

Output Voltage, Volts

Output Electric Power, kW

Power Conversion Efficiency, \%

Number of Units Required

\section{Recycle Gas Blower}

Adiabatic Efficiency, \%

Differential Pressure, $\mathrm{kPa}$

Shaft Horse Power, $\mathrm{kW}$

Motor Efficiency, \%

Number of Units

\section{Gas Turbine Design}

Compression Ratio

Compressor Air Flow, kg/s

Compressor Efficiency, \%

Turbine Efficiency, \%

Generator Efficiency, \%

Net Power Production, $\mathrm{kW}$

Overall Electrical Efficiency
Start of Run

SOR

End of Run

\section{EOR}

Type: Extemal/Separate - IHI Gas-Heated Plate-Type

$\begin{array}{rr}4.68 & 5.3 \\ 1.43 & 1.5 \\ 606 & 606 \\ 1,061 & 1,061 \\ 1,018,806 & 1,026,361 \\ 36 & 36\end{array}$

Type: MC-Power Molten Carbonate, Co-Flow

$\begin{array}{rr}605 & 605 \\ 200 & 200 \\ 758 & 700 \\ 1.52 & 1.40 \\ 80.4 & 80.3 \\ 86.2 & 86.5 \\ 36 & 36\end{array}$

Type: Solid-State

227

210

2,180

2,180

4,160

4,160

479

443

97.5

97.5

9

9

75

75

6.2

6.2

108

119

92

92

3

3

Type: Rolls-Royce Allison

$\begin{array}{rr}6.16 & 6.16 \\ 16.81 & 19.19 \\ 84 & 84 \\ 91.9 & 91.9 \\ 98.5 & 98.5 \\ & \\ 20,115 & 19,159 \\ 70.11 & 66.78\end{array}$


TABLE 2

Performance Summary

Site Elevation - Sea Level

\section{Start-of-Run Operation}

Ambient Temperature, ${ }^{\circ} \mathrm{C}$

15

49

49

Relative Humidity

$60 \%$

$0 \%$

$0 \%$

$100 \%$

AC Power from Power Modules, $\mathrm{kW}$

17,256

17,256

17,256

17,256

AC Power from Gas turbine Generator, $\mathrm{kW}$

3,429

3,603

3,246

3,242

Gross Power Production, kW

Auxiliary Loads, $\mathrm{kW}$

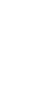

20,685

20,859

20,502

20,498

$\frac{570}{20,115} \frac{571}{20,288} \frac{571}{19,931} \frac{563}{19,935}$

Natural Gas Consumption, $\mathrm{kJ} / \mathrm{h}$ (LHV)

$1.0328 \mathrm{E}+08$

$1.0328 \mathrm{E}+08$

$1.0328 \mathrm{E}+08$

$1.0328 \mathrm{E}+08$

Fuel Fired in Gas Turbine, $\mathrm{kJ} / \mathrm{h}$ (LHV)

0

0

0

0

Fuel Fired in HRSG, kJ/h (LHV)

0

0

$0 \quad 0$

Overall Electrical Efficiency (LHV), \%

70.11

70.72

69.47

69.49 
TABLE 3

Performance Summary

Site Elevation - 5,000'

\section{Start-of-Run Operation}

Ambient Temperature, ${ }^{\circ} \mathrm{C}$

15 $-29$

49

Relative Humidity

$60 \%$

$0 \%$

$0 \%$

$100 \%$

AC Power from Power Modules, $\mathrm{kW}$

17,256

17,256

17,256

17,256

AC Power from Gas turbine Generator, $\mathrm{kW}$

3.099

3,368

2.819

2,845

Gross Power Production, kW

20,355

20,624

20,075

20,101

Auxiliary Loads, $\mathrm{kW}$

$\begin{array}{r}570 \\ \hline 19,785\end{array}$

Natural Gas Consumption, kJ/h (LHV)

$1.0328 \mathrm{E}+08$

$1.0328 \mathrm{E}+08$

$1.0328 \mathrm{E}+08$

$1.0328 \mathrm{E}+08$

Fuel Fired in Gas Turbine, kJ/h (LFV)

0

0

0

0

Fuel Fired in HRSG, kJ/h (LHV)

0

0

0

0

Overall Electrical Efficiency (LHV), \%

68.96

69.90

67.98

68.10 
TABLE 4

Performance Summary

Site Elevation - Sea Level

\section{End-of-Run Operation}

Ambient Temperature, ${ }^{\circ} \mathrm{C}$

Relative Humidity

$60 \%$

$0 \%$

AC Power from Power Modules, $\mathrm{kW}$

AC Power from Gas turbine Generator, $\mathrm{kW}$

Gross Power Production, $\mathbf{k W}$

Auxiliary Loads, kW

608

610

Net Power Production, kW

19,159

18,931

Natural Gas Consumption, kJ/h (LHV)

Fuel Fired in Gas Turbine, $\mathrm{kJ} / \mathrm{h}$ (LHV)

Fuel Fired in HRSG, $\mathrm{kJ} / \mathrm{h}$ (LHV) 


\section{A.3. Optimum Operáting Pressure Study}

After establishing the design sbincept, the BOP equipment configuration, and equipment design parameters, the next priority to select the system operating pressure. In this study, pressure selection is based on process formance. i.e., the pressure, which results in the highest naturalgas-conversion efficiency, is islected.

\section{Feed Stream Conditions $\mathrm{nC}$}

Per the study basis, process strbams delivered to the battery limit are either at some nominal supply pressure, or else ambiewte pressure.

a Natural gas is supplied at $305 \mathrm{kPa}$, and has to be compressed to the system pressure.

- Ambient air, the oxidant anit cooling streams in the fuel cells, is compressed to system pressure by the gas turbinexompressor.

- Finally, steam is suppliedstat the power modules above system pressure, since steam is the motive fluid for the recyclleigas ejector.

Three system pressures were ${ }^{2}$ sidered: $600 \mathrm{kPa}, 1,000 \mathrm{kPa}$ and $1,400 \mathrm{kPa}$. These pressures cover the pressure-ratio rangessfor aero-derivative gas turbines proposed by Rolls-Royce Allison.

Process simulations of the proposed design concept (power module, gas turbine, and HRSG unit) were performed at the differentoperating pressures, with equipment performance characteristics provided by equipment supplieqs.

\section{Effect of Pressure on PowerefGeneration Efficiency}

\section{1) MCFC Stacks tac}

The efficiency at which an $\mathrm{yC}$ stack converts chemical energy to electric power is directly proportional to the ratio of pettential developed to the open circuit voltage. The Nernst equation defines the relationship betwo the cell's reversible potential and reactant partial pressures. An increase in system pressure ressilts in an increase in cell potential. In addition, higher pressure enhances mass transfer and reastion kinetics at the electrodes, helping reduce the overpotentials thereby increasing the operatiagi voltage. The MCFC efficiency increases from $59 \%$ to $61 \%$ as the pressure is increased fromi $600 \mathrm{kPa}$ to $1400 \mathrm{kPa}$.

\section{Other Effects of Pressure :ts ।}

In addition to the above, systentilpressure affects the design and operation of MCFC stacks in several other ways. $\mathrm{r} w:$

\section{Stack Pressure Drop ure}

For a fixed cell configuration ehd stack design, higher pressure reduces the pressure loss for the fuel and oxidant streams. Lodkapressure drop is especially important for the flow of oxidant/cooling gas to the cattrgede compartments. A motor-driven blower delivers this stream to 
the cathode compartments and recycles cathode exhaust back to the blower as part of the stack cooling process. The power requirements for the recycle blower are reduced significantly at higher operating pressures.

\section{Cathode Dissolution}

High $\mathrm{CO}_{2}$ partial pressures can lead to nickel dissolution at the cathode - eventually leading to degradation of the cathode.

\section{Carbon Formation}

If carbon formation at the anode inlet occurs by the Boudouard reaction, then, since this reaction is favored by high pressure, the Boudouard carbon formation point moves closer to the operating condition of the anode feed gas. i.e., the safety margin between the anode inlet gas temperature and Boudouard carbon formation is reduced.

\section{Electrolyte Vaporization}

Since the carbonate evaporation rate is inversely proportional to the $\mathrm{CO}_{2}$ partial pressure, loss of electrolyte through vaporization is reduced at higher pressures.

\section{2) Gas-Turbine Generator Set}

The cycle efficiency for the HEFPP gas turbine generator, relative to its maximum, is shown in Figure 1. The performance as a function of pressure ratio is based on a gas turbine operating as the "unfired" bottoming cycle to a MCFC power module (with fixed steam and natural gas flows) and for a fixed amount of waste heat available from the power modules. 


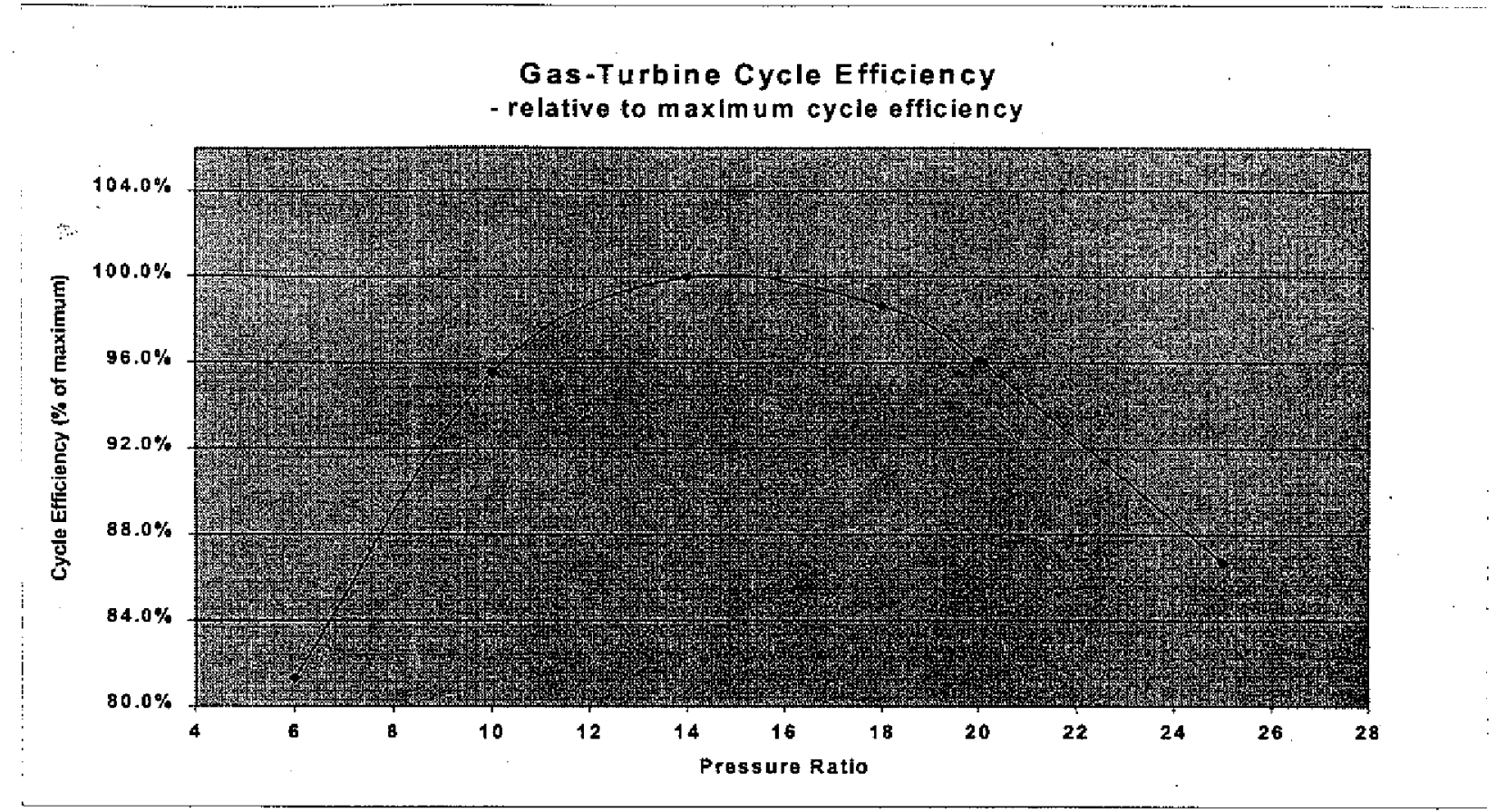

From the figure above, the gas-turbine cycle maximum efficiency (ratio of net power produced to heat input') occurs in the pressure-ratio range $12-16^{2}$.

As mentioned above, the HEFPP plant is expected to achieve maximum natural-gas-conversion efficiency when the MCFC stacks and the gas turbine are both operating at their maximum cycle efficiencies.

From the figures above, the optimum operating pressure appears to be somewhere in the range $1,000-1,600 \mathrm{kPa}$. However, this is an incomplete assessment, for, when the MCFC and the gasturbine are integrated with BOP equipment a different picture emerges as discussed below.

\section{Turbine Exhaust Temperature}

For simple gas turbine cycles, the higher the pressure ratio, the lower the turbine exhaust temperature. For a $978^{\circ} \mathrm{K}$ turbine inlet temperature, pressure ratios of 10 and above lead to turbine exhaust temperatures that are too low to preheat natural gas to the desulfurization temperature and too low to raise the process steam requirements. Simply put, as the system pressure increases above $600 \mathrm{kPa}$, the turbine exhaust has insufficient energy at the right temperature level to meet the process heating requirements.

\footnotetext{
'Power module waste heat is held constant.

${ }^{2}$ As the pressure ratio tends to 1 the net work tends to zero. At the maximum pressure ratio, where the compressor discharge tends to the turbine inlet temperature, the net work also tends to zero.
} 
Turbine Exhaust Temperature, @ $978^{\circ} \mathrm{K}$ inlet temperature

\begin{tabular}{lccc} 
Pressure Ratio & 6 & 10 & 14 \\
Exhaust Temperature, ${ }^{\circ} \mathrm{K}$ & 670 & 593 & 547 \\
\hline
\end{tabular}

Above $600 \mathrm{kPa}$ it is necessary to fire fuel in either the turbine combustor or a HRSG duct burner. This effect is made worse by the steam saturation temperature, which increases as the system pressure (and therefore the steam pressure) increases.

Fuel combusted in either the reformer combustor or the gas-turbine combustor can only be converted to electric power through the gas-turbine cycle, at its cycle efficiency.

Consequently, for the concept proposed for the HEFPP demonstration plant, higher operating pressures result in lower overall electrical conversion efficiencies. Therefore, $610 \mathrm{kPa}$ operating pressure was selected for the system design.

A summary of plant performances at different system operating pressures is shown in Table 5 .

\section{Effect of Pressure on BOP Systems}

The following is a summary of the effects of system pressure on BOP equipment.

\section{Natural Gas Compressor}

Power consumption, design complexity, and cost for the natural gas compressor increase with increasing operating pressure.

\section{Steam System}

Increased system operating pressure means that steam for the ejector and fuel processor has to be raised at higher saturation temperature. However, increased system pressure results in lower turbine exhaust temperatures. Above $600 \mathrm{kPa}$, these two temperatures diverge from one another, making it necessary to combust fuel to redress the situation.

\section{Fuel Processor}

Increased operating pressure reduces methane conversion in the reformer. With increasing pressure, the target conversion is achieved either through higher reforming temperatures and/or increased steam flow. Otherwise, lower conversion has to be accepted, and the natural gas feed has to be increased. For $1,000 \mathrm{kPa}$ and $1,400 \mathrm{kPa}$ operating pressures, increasing the steam supply proved to be more efficient than accepting lower natural gas conversions by approximately $1 \%$ in natural-gas-conversion efficiency.

Any unconverted methane passes through the anode compartment to the reformer combustor, where it is combusted along with unconverted $\mathrm{MCFC}$ fuel $\left(\mathrm{H}_{2}\right.$ and $\left.\mathrm{CO}\right)$. If there is sufficient $\mathrm{H}_{2}$ and $\mathrm{CO}$ in the MCFC anode exhaust (flowing to the combustor) to supply the reformer heat duty at the correct temperature levels, then combustion of unconverted methane serves no other purpose than to generate power through the gas-turbine cycle, and should be avoided, or minimized. 
Therefore, as far as the fuel processor is concerned, higher pressure operation tends to reduce natural-gas-conversion efficiency - either through increased methane slip, or from additional energy requirements to operate the reformer at higher temperature and/or to provide additional steam.

\section{Recycle Blower}

At higher system pressures the recycle blower has lower volumetric throughputs and has to develop less differential head. The net effect is to lower the plant auxiliary load.

\section{Power Module Vessel}

The operating pressure of the power module vessel is effectively the same as the system pressure. For the same diameter vessel (fixed equipment and piping sizes), higher pressures lead to thicker vessel walls. Higher pressures also lead to hotter purge air from the compressor. For a pressure ratio of $14: 1$ and an ambient temperature of $49^{\circ} \mathrm{C}$, the vessel purge air temperature is close to $700^{\circ} \mathrm{K}$. These temperatures present additional design challenges for equipment instrument cables and vessel design temperatures.

\section{Power Module Equipment Heat Loss}

Power module equipment inside the vessel and the vessel itself are both thermally insulated to minimize heat loss - see discussion above. 
TABLE 5

HEFPP Performance Summary

At Different Operating Pressures

Operating Pressure, $\mathrm{kPa}$

610

1010

1420

Cell Voltage, $\mathrm{mV}$

758

771

785

Per-pass Fuel Utilization, \%

80

59.1

Cell Efficiency, \%

54

98.2

80

60.2

80

Cathode-Inlet $\mathrm{CO} 2$ partial pressure, $\mathrm{kPa}$

85

61.2

112

Reformer - Feed Methane Conversion, \%

97.2

94.7

Steam Pressure, $\mathrm{kPa}$

896

Saturation Temperature, $\mathrm{K}$

448

BFW Consumption, $\mathrm{kg} / \mathrm{h}$

5,899

Compression Ratio

6.2

518

Compressor Discharge Temperature, $\mathrm{K}$

Gas Turbine N.G. Fuel, kJ/h (LHV)

Gas Turbine Inlet Temperature, $\mathrm{K}$

Gas Turbine Exhaust Temperature, $\mathrm{K}$

978

671

36

33

1,710

1,303

465

6,199

478

5,838

Number of Power Modules

17,157

3,409

353

213

N.G. Compressor Power Consumption, $\mathbf{k W}$

2000

Net Power output, $\mathrm{kW}$

20,000

15,380

5,043

124

299

20,000

14.3

666

$1.433 \mathrm{E}+07$

1,124

$2.072 \mathrm{E}+07$

1,167

674

30

14,487

5,943

65

365

20,000

N.G. Fuel to G.T. Combustor, $\mathrm{kg} / \mathrm{h}$

N.G. Feed to Steam Reformer, $\mathrm{kg} / \mathrm{h}$

Total N.G. Fuel Consumption, kJ/h (LHV)

$\begin{array}{rrr}2,244 & 313 & 453 \\ 1.027 \mathrm{E}+08 & 1,988 & 1,895 \\ & 1.053 \mathrm{E}+08 & 1.074 \mathrm{E}+08 \\ \mathbf{7 0 . 1} \% & \mathbf{6 8 . 4} \% & \mathbf{6 7 . 0 \%}\end{array}$

Overall Conversion Efficiency (LHV), \%

$70.1 \%$

$68.4 \%$

$67.0 \%$ 


\section{A.4. Optimum Number of Spare Trains for Each Major Process Area}

To perform maintenance on any power module component, the power-module vessel has to be depressurized. The number of power modules contained in a single vessel is a compromise between vessel size, number of vessel penetrations, transportation limitations, and the power-loss burden to maintain, or replace, a single power module. With four power modules per vessel the power reduction incurred by taking a single vessel off-line is $11 \%$. Similarly, loss of a single fuel cell inverter will reduce the plant output by $11 \%$ and force the power module vessel to be shutdown.

With four modules per vessel and thirty-six modules required for a $20 \mathrm{MW}$ facility, there is a total of nine power-module vessels.

A single recycle blower serves three power-module vessels (12 power modules). This creates three power trains. Shutdown of a single blower results in the shutdown of its power train, and the loss of one-third of plant capacity.

Because of the modular nature of fuel cell power generation, there is appreciable manifolding and sub-manifolding required to distribute feed, exhaust, and utility streams to and from all the power modules.

An alternative arrangement is to locate all power modules inside a single, field-fabricated vessel. ' The advantages to this are: economy-of-scale cost reduction for the vessel, distribution to equipment is made inside the vessel (fewer vessel penetrations), most of the high-temperature piping is inside the vessel and therefore less insulation is needed, and piping design pressures and flange ratings can be lower. The main disadvantage is the need to shutdown the entire facility in order to maintain equipment inside the stack. 


\section{B. SYSTEM DEFINITION}




\section{B System Definition}

\section{B.1 Process Description}

Please refer to the Process Flow Diagram in Section 3.B.3 for better understanding of process.

\section{Natural Gas Supply \& Conditioning}

Two, $100 \%$ capacity, motor-driven compressors (one operating, one standby) boost the natural gas from supply pressure to system operating pressure, $749 \mathrm{kPa}$. A heat-exchange coil in the HRSG unit preheats the pressurized natural gas to desulfurization temperature, $616^{\circ} \mathrm{K}$. Natural gas desulfurization takes place in a cylindrical vessel packed with zinc oxide. Following desulfurization, the natural gas splits into three equal streams - each stream flowing to one of the three MCFC power trains. Each power train contains three power module vessels, and each vessel contains four individual power modules. Natural gas is distributed to each of the power modules (thirty-six total).

\section{Steam Supply \& Conditioning}

Demineralized boiler feed water (BFW) is supplied to the plant battery limit. An economizer coil (also inside the HSRG unit) preheats demineralized BFW before it enters the deaeartor. The deaerator strips the BFW of dissolved oxygen by contacting it with steam, over trays or packing. Deaerated BFW has a residual oxygen concentration of $5 \mathrm{ppb}$. BFW is then pumped through the $\mathrm{BFW}$ heater to an elevated steam drum, where steam is generated by natural circulation. Saturated steam leaves the steam drum and goes to a superheater where the steam is superheated. The superheated steam leaves the superheater and is distributed to the individual power modules.

\section{Power Module}

A single power module consists of a fuel processor (reformer), its supporting equipment, and a 500-kW MCFC stack. There are thirty-six power modules in total.

\section{Power Module Vessel}

Each power module vessel contains four separate power modules. The power module vessels are pressurized to the system operating pressure, i.e. the operating pressure of the fuel processors and the fuel-cell stacks. A small flow of compressed air simultaneously purges the vessel and maintains vessel pressure. The air stream flows from the vessel to the process side of the power module, and prevents combustible gases from accumulating inside the vessel in the event of an equipment leak. The fuel cells are connected electrically in series. A single power module vessel provides power for one inverter which is located externally, but adjacent to the vessel. 


\section{Fuel Processing}

Natural gas is converted to a hydrogen-rich fuel stream by steam reforming. IHI will utilize a similar plate type reformer which has been used successfully on the $250 \mathrm{~kW}$ Test Facility at Miramar.

\section{Anode Recycle (Ejector)}

Recycling part of the anode exhaust through an ejector creates a recycle flow between the MCFC stack and the fuel processor. Steam flow to the individual power modules is the motive fluid for the ejectors.

The steam-anode exhaust stream from the ejector is mixed with natural gas and then preheated to $919^{\circ} \mathrm{K}$ by heat exchange with the hydrogen-rich fuel stream leaving the reformer.

\section{Pre-reformer}

The pre-reformer starts the steam-reforming of the feed hydrocarbon, only under adiabatic conditions. The process stream temperature drops from $919^{\circ} \mathrm{K}$ to $799^{\circ} \mathrm{K}$ as $23 \%$ of the methane in the feed is reformed.

\section{Reformer}

The reformer is a plate-type design of alternating reforming and heat transfer sections.

The partially reformed feed stream from the pre-reformer enters the IHI plate-type steam reformer where it is fully reformed to the hydrogen-rich product stream. The operating conditions at the reformer exit are $606 \mathrm{kPa}$ and $1,061^{\circ} \mathrm{K}$.

The source of energy needed to sustain the reforming reactions is provided from combustor exhaust gas as it flows through the heat transfer sections of the reformer. The anode exhaust gas not recycled to the reformer is fed to the catalytic combustor, where residual $\mathrm{CH}_{4}, \mathrm{CO}$, and $\mathrm{H}_{2}$ are combusted to provide the temperature and flow conditions necessary to transfer heat to the reformer.

Hydrogen-rich fuel from the reformer (reformate) is cooled to the fuel cell anode feed temperature in the reformer feed/effluent heat exchanger. The reformate then is piped to the fuel cell anode inlet.

\section{Molten Carbonate Fuel Cell (MCFC)}

The fuel and oxidant are consumed by charge transfer reactions in the MCFC stack. The reactions cause a potential difference between electrodes. 


\section{Anode}

The hydrogen-rich fuel enters the anode at $950^{\circ} \mathrm{K}$, undergoes oxidation charge transfer reactions at the gas/electrode/electrolyte interface, and leaves the stack at $978^{\circ} \mathrm{K}$. Carbonate ions from the electrolyte are converted to carbon dioxide at the reaction sites, and leave the stack in the anode exhaust stream.

The stack consists of a number of cells arranged in parallel. Anode feed gas is distributed uniformly to each cell by the inlet manifold. Uniform distribution across the plate surface is achieved by providing channels in the anode compartment for the gas to flow through. Gas exiting the cell is collected in the outlet manifold.

At start-of-run conditions the cell voltage is $757 \mathrm{mV}$ and the average current density is 200 $\mathrm{mA} / \mathrm{cm} 2$. The cells are electrically connected in series, and therefore the stack develops practical voltages.

\section{Cathode}

The cathode feed stream comes from the three recycle blowers. Each cathode recycle blower feeds three power module vessels for a total of 12 fuel cells. The feed into each cathode blower is a mixture of three streams. The first is reformer flue gas which for a single recycle blower is collected from the 12 reformers (total) in the three power module vessels. The second stream added before the cathode recycle blower inlet is the cathode exhaust recycle gas. The third stream added before the cathode blower inlet is the air from the gas turbine compressor section. The air provides an oxidant supply and the fuel cell stack cooling. The first two streams, when mixed together, provide a source of carbon dioxide to replenish the electrolyte after carbonate ion oxidation at the anode. The cathode recycle blower provides homogeneous mixing of the three streams mentioned above and minimizes stratification of a single stream.

The cathode feed stream enters the stack at $866^{\circ} \mathrm{K}$. Oxygen and carbon dioxide undergo reduction charge transfer reactions at the gas/electrode/electrolyte interface. The gas leaves the stack at $978^{\circ} \mathrm{K}$.

Cathode feed gas is distributed uniformly to each cell by an inlet manifold. Uniform distribution across the plate surface is achieved by providing channels in the cathode compartment for the gas to flow through. Gas exiting the cell is collected in the outlet manifold.

\section{Recycle Blower}

The energy difference between the oxidant/fuel heat-of-reaction and the useful work produced by the MCFC stack is released as heat. This heat must be removed to maintain isothermal operating conditions inside the stack.

Stack cooling is provided to a small extent by gas flow through the anode compartment. However, most of the cooling is provided by the flow of gas through the cathode compartment approximately twelve times the mass flow of anode gas. 
The recycle blower creates the cathode recycle stream, which, when added to air from the compressor and the processed feed stream, provides the gas flow needed to cool the stack.

\section{Inverter}

For utility systems, such as this program, the d.c. output from four MCFC fuel cells must be converted to utility-quality a.c. power.

The inverter converts the combined power module fuel cell output voltage of $800-900 \mathrm{~V} d c$ into $4160 \mathrm{VAC}, 3$ phase, power for export to the grid, and for use by the plant auxiliaries. The multiple inverter power is collected in a common bus and is joined with the turbine generator power for feed into the step up transformer. The stepup transformer high side bushings are the primary utility interface point.

\section{Gas-Turbine Generator}

Cathode-exhaust gas from the thirty-six power modules combines into a single stream which leads to the turbine (expander) section of the gas turbine generator. The high pressure exhaust and heat energy is used to drive the gas turbine compressor section and alternator section. Exhaust gas leaves the turbine section and is ducted to the HRSG. Atmospheric air is compressed in the gas turbine compressor section to approximately $610 \mathrm{kPa}$. The gas turbine generator system produces $4160 \mathrm{VAC}$ for use in plant auxiliaries and the electric utility grid.

\section{HRSG}

Waste heat from the turbine exhaust is recovered in the HRSG unit by convective heat transfer. Heat is transferred to preheat natural gas, raise and superheat steam, preheat BFW, and preheat demineralized make-up water. The exhaust gas is discharged to the atmosphere at $446^{\circ} \mathrm{K}$.

\section{Design Requirements}

A design specification for the plant appears in Table 6. 
Table 6

Design Specification

\begin{tabular}{|c|c|}
\hline Application & $\begin{array}{l}\text { Commercial distributed power generation } \\
\text { utility - grid connected. }\end{array}$ \\
\hline Fuel & $\begin{array}{l}\text { Natural Gas } \\
\text { Composition: - Mol\% } \\
\mathrm{CH}_{4} \quad 96.0 \\
\mathrm{~N}_{2} \quad 2.0 \\
\mathrm{CO}_{2} \quad 2.0 \\
\mathrm{~S} \quad 4 \text { ppmv - mercaptan } \\
\\
\text { Supply pressure } \quad 15 \mathrm{psig} \\
\text { Supply temperature } \quad 59^{\circ} \mathrm{F}\end{array}$ \\
\hline Oxidant & $\begin{array}{ll}\text { Air composition: }-\mathrm{Mol} \% \\
\mathrm{O}_{2} \quad 20.7 \\
\mathrm{~N}_{2} \quad 78.0 \\
\mathrm{CO}_{2} \quad 0.3 \\
\text { Water } \quad 1.0(60 \% \text { relative humidity }) \\
\\
\text { Ambient air temperature } 59^{\circ} \mathrm{F} \\
\text { Ambient air pressure } \quad 14.7 \mathrm{psia} \\
\end{array}$ \\
\hline Performance Requirements & $20 \mathrm{MW}$ net $\mathrm{AC}$, \\
\hline Power System Design-Point Capacity & $+/-2 \mathrm{MW}$ \\
\hline Design-Point Efficiency & $>70 \%$ (net AC/LHV) \\
\hline Power System Dispatch Mode & Base loaded \\
\hline $\begin{array}{l}\text { Power System Normal-Operation } \\
\text { Tumdown Requirement }\end{array}$ & None \\
\hline Power system Overpower Requirement & None \\
\hline Output Power Conditions & $60 \mathrm{~Hz}$, Utility-grid quality \\
\hline Noise Control & $\begin{array}{l}\text { Consistent with typical gas turbine power } \\
\text { plant practice }\end{array}$ \\
\hline $\begin{array}{l}\text { Ambient Air Parameter Ranges } \\
\text { Pressure }\end{array}$ & Sea level to $5,000 \mathrm{ft}$. \\
\hline Temperature & $-20^{\circ} \mathrm{F}$ to $120^{\circ} \mathrm{F}$ \\
\hline Relative Humidity & 0 to $100 \%$ \\
\hline
\end{tabular}




\begin{tabular}{|c|c|}
\hline \multicolumn{2}{|l|}{ Power System Physical Design Objectives } \\
\hline Installation & Outdoors \\
\hline Transportation Options & Truck, sea, air, rail \\
\hline Transportation Basis & 500 miles \\
\hline Plant Design Lifetime & $\begin{array}{l}\text { Conventional power plant equipment }-25 \\
\text { years }\end{array}$ \\
\hline Utilities & $\begin{array}{l}\text { All utilities needed to support the plant will } \\
\text { be available at the site }\end{array}$ \\
\hline \multicolumn{2}{|l|}{ Power Plant Operation } \\
\hline Annual Operating Time & Fifty weeks \\
\hline Annual Planned Shutdown & Two weeks \\
\hline \multicolumn{2}{|l|}{$\begin{array}{l}\text { Instrumentation and Control } \\
\text { The I\&C system design concept and cost } \\
\text { will be based on the projected needs of } \\
\text { mature fuel ceil/gas turbine technologies } \\
\text { and commercial power plant operation }\end{array}$} \\
\hline \multicolumn{2}{|l|}{ Economic Evaluation Parameters } \\
\hline Power system Cost Estimation Basis & $\begin{array}{l}\text { Mature technologies and integration } \\
\text { techniques, not first-of-a-kind. }\end{array}$ \\
\hline Cost Basis & Mid-1998 US Dollars \\
\hline Fuel Cost & $\$ 3.00 / \mathrm{MMBtu}(\mathrm{HHV})$ \\
\hline Capital Charge Rate & $15 \%$ \\
\hline Capacity Factor & $92 \%$ \\
\hline COE Evaluation Method & Constant Dollars \\
\hline Power Plant Optimization Basis & $\begin{array}{l}\text { Consistent with }>70 \% \text { (LHV) efficiency, } \\
\text { achieve a design-point COE that is } 10-20 \% \\
\text { below the COE achieved by today's } \\
\text { conventional-plant technology }\end{array}$ \\
\hline $\begin{array}{l}\text { Conventional Power Plant Basis } \\
\text { - for COE comparison purposes }\end{array}$ & Comparably sized gas turbine cycle \\
\hline
\end{tabular}




\section{B.2. Plant Performance Summary}

\section{B.2.a Fuel Cell Stacks}

The rated fuel cell performance based on an ambient temperature of $288^{\circ} \mathrm{K}$, relative humidity of 60 percent, sea level elevation, and $101.3 \mathrm{kPa}$ absolute atmospheric pressure at beginning and end of fuel cell life appears below:

Parameter

Number of Stacks

Current Density ( $\mathrm{mA} / \mathrm{cm}$ squared)

Millivolts/Cell

Power Density (kW/meter squared)

$\mathrm{kW} /$ Stack

$\mathrm{kW}$ Total from all Stacks

Operating Pressure $(\mathrm{kPa})$

Fuel Utilization-Per Pass (\%)

Fuel Utilization-Overall (\%)
Beginning of Life

36

200

758

1.52

496

17,856

605

80.4

86.2
End of Life

36

200

700

1.40

458

16,488

605

80.3

86.5 


\section{B.2.b Turbine Generator}

The gas turbine generator predicted performance at $288^{\circ} \mathrm{K}, 101 \mathrm{kPa}$ absolute, and sea level conditions for the fuel cell beginning of life and end of life conditions appears below:

Parameter

Compressor

Compressor Inlet Temperature $\left({ }^{\circ} \mathrm{K}\right)$

Compressor Inlet Pressure $(\mathrm{kPa})$

Compressor Mass Flow $(\mathrm{kg} / \mathrm{sec})$

Compressor Outlet Pressure $(\mathrm{kPa})$

Compressor Outlet Temperature $\left({ }^{\circ} \mathrm{K}\right)$

Compression Ratio

Compressor Efficiency (\%)

Turbine

Turbine Inlet Temperature $\left({ }^{\circ} \mathrm{K}\right.$ )

Turbine Inlet Pressure ( $\mathrm{kPa})$

Turbine Mass Flow $(\mathrm{kg} / \mathrm{sec})$

Turbine Outlet Pressure ( $\mathrm{kPa})$

Turbine Outlet Temperature $\left({ }^{\circ} \mathrm{K}\right)$

Turbine Efficiency (\%)

Generator

Generator Efficiency (\%)

Power Conditioner

Power Conditioner Output Voltage (V)

Power Conditioner Output Current (A)

Power Conditioner Output Power (kW)

Power Conditioner Output Frequency $(\mathrm{Hz})$

Power Conditioner Output Phases

Power Conditioner Efficiency (\%)

Beginning of Fuel Cell Life End of Fuel Cell Life

288

101

16.8

621

518

6.16

84

978

594

19.1

105

671

91.9

98.5

4160

476

3429

60

3

97.5
288

101

19.2

621

518

6.16

84

978

594

21.6

105

669

91.9

98.5

4160

530

3821

60

3

97.5 


\section{B.2.c Overall Plant}

Plant performance summary tables are provided for the following cases:

Table 7 - Major Subsystem Design Parameters and Operating Conditions. This table represents expected operating conditions for major plant components at SOR and EOR fuel cell conditions for a plant at sea level.

Table 8 - Start of Run (SOR), sea level summary performance table. This table presents performance data for three different ambient air temperatures, at SOR, full-load operation and for a plant site at sea level.

Table 9 - Start of Run (SOR), 5,000 ft elevation summary performance table. This table presents performance data for three different ambient air temperatures, at SOR, full-load operation and for a plant site at $5,000 \mathrm{ft}$ elevation.

Table 10 - End of Run (EOR), sea level summary performance table. This table presents performance data for two ambient air temperatures, at EOR, full-load operation and for a plant site at sea level. 
TABLE 7

Major Subsystem

Design Parameters and Operating Conditions

Site Elevation - Sea Level

$\begin{array}{cc}\text { Start of Run } & \text { End of Run } \\ \text { SOR } & \text { EOR }\end{array}$

Fuel Processor - Reformer

Steam:Hydrocarbon ratio

Steam:Total Carbon ratio

Operating Pressure, $\mathrm{kPa}$

Exit Temperature, $\mathrm{K}$

Process Duty, kJ/h

Number of Units

\section{Fuel Cell Stack Design}

Operating Pressure, $\mathrm{kPa}$

Current Density, $\mathrm{mA} / \mathrm{cm} 2$

Cell Voltage, $\mathrm{mV}$

Power Density, $\mathrm{kW} / \mathrm{m} 2$

Fuel Utilization - per pass, \%

Fuel Utilization - overall, \%

Number of Stacks Required

\section{Inverter Design}

Input Voltage, Volts

Input Current, Amps DC

Output Voltage, Volts

Output Electric Power, kW

Power Conversion Efficiency, \%

Number of Units Required

Recycle Gas Blower

Adjabatic Efficiency, \%

Differential Pressure, $\mathrm{kPa}$

Shaft Horse Power, kW

Motor Efficiency, \%

Number of Units

\section{Gas Turbine Design}

Compression Ratio

Compressor Air Flow, $\mathrm{kg} / \mathrm{s}$

Compressor Efficiency, \%

Turbine Efficiency, \%

Generator Efficiency, \%

Net Power Production, $\mathrm{kW}$

Overall Electrical Efficiency
Type: External/Separate - IHI Gas-Heated Plate-Type

$\begin{array}{rr}4.68 & 5.3 \\ 1.43 & 1.5 \\ 606 & 606 \\ 1,061 & 1,061 \\ 1,018,806 & 1,026,36 \mathrm{I} \\ 36 & 36\end{array}$

Type: MC-Power Molten Carbonate, Co-Flow

605

200

200

758

700

1.52

1.40

80.4

80.3

86.2

86.5

36

Type: Solid-State

227

210

2,180

2,180

4,160

4,160

479

443

97.5

97.5

9

9

75

75

$6.2 \quad 6.2$

$108 \quad 119$

$92 \quad 92$

3

3

Type: Rolls-Royce Allison

$\begin{array}{rr}6.16 & 6.16 \\ 16.81 & 19.19 \\ 84 & 84 \\ 91.9 & 91.9 \\ 98.5 & 98.5\end{array}$

20,115

19,159

70.11

66.78 
TABLE 8

Performance Summary

Site Elevation - Sea Level

\section{Start-of-Run Operation}

Ambient Temperature, ${ }^{\circ} \mathrm{K}$

Relative Humidity

$60 \%$

$0 \%$

$0 \%$

$100 \%$

AC Power from Power Modules, $\mathrm{kW}$

17,256

17,256

17,256

17,256

$\mathrm{AC}$ Power from Gas turbine Generator, $\mathrm{kW}$

3.429

3.603

3.246

3,242

Gross Power Production, kW

Auxiliary Loads, $\mathrm{kW}$

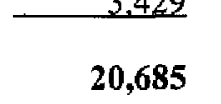

20,859

20,502

20,498

570

571

571

563

Net Power Production, kW

20,115

20,288

19,931

19,935

Natural Gas Consumption, $\mathrm{kJ} / \mathrm{h}$ (LHV)

$$
1.0328 \mathrm{E}+08 \quad 1.0328 \mathrm{E}+08
$$

$1.0328 \mathrm{E}+08 \quad 1.0328 \mathrm{E}+08$

Fuel Fired in Gas Turbine, $\mathrm{kJ} / \mathrm{h}$ (LHV)

0

0

0

0

Fuel Fired in HRSG, kJ/h (LHV)

0

0

0

0

Overall Electrical Efficiency (LHV), \%

70.11

70.72

69.47

69.49 
TABLE 9

Performance Summary

Site Elevation - 5,000'

\section{Start-of-Run Operation}

Ambient Temperature, ${ }^{\circ} \mathrm{K}$

288

244

322

322

Relative Humidity

$60 \%$

$0 \%$

$0 \%$

$100 \%$

AC Power from Power Modules, $\mathrm{kW}$

17,256

17,256

17,256

17,256

AC Power from Gas turbine Generator, $\mathrm{kW}$

3,099

3.368

2.819

2.845

Gross Power Production, $\mathrm{kW}$

Auxiliary Loads, $\mathrm{kW}$

3,099
20,355

570

20,624

20,075

20,101

Net Power Production, $\mathrm{kW}$

19,785

$\frac{571}{\mathbf{2 0 , 0 5 2}}$

571

563

$19,504 \quad 19,538$

Natural Gas Consumption, $\mathrm{kJ} / \mathrm{h}$ (LHV)

$$
1.0328 \mathrm{E}+08
$$

$1.0328 \mathrm{E}+08$

$1.0328 \mathrm{E}+08$

$1.0328 \mathrm{E}+08$

Fuel Fired in Gas Turbine, kJ/h (LHV)

0

0

0

0

Fuel Fired in HRSG, kJ/h (LHV)

0

0

0

0

Overall Electrical Efficiency (LHV), \%

68.96

69.90

67.98

68.10 
TABLE 10

Performance Summary

Site Elevation - Sea Level

\section{End-of-Run Operation}

Ambient Temperature, ${ }^{\circ} \mathrm{K}$

Relative Humidity

$60 \%$

$0 \%$

AC Power from Power Modules, $\mathrm{kW}$

AC Power from Gas turbine Generator, $\mathrm{kW}$

…

Gross Power Production, kW

19,767

19,541

Auxiliary Loads, $\mathrm{kW}$

608

610

Net Power Production, kW

19,159

18,931

Natural Gas Consumption, $\mathrm{kJ} / \mathrm{h}$ (LHV)

Fuel Fired in Gas Turbine, $\mathrm{kJ} / \mathrm{h}$ (LHV)

Fuel Fired in HRSG, kJ/h (LHV)

Overall Electrical Efficiency (LHV), \%

66.78

65.99 


\section{B.3. Process Flow Diagram}

\section{Start-of-Run (SOR) Operation}

DWG B-001 is the process flow diagram (PFD) for the HEFPP overall facility. It depicts the design and control concepts, process equipment, and presents the flows and conditions for all streams entering and exiting the facility, including electric power.

DWG B-002 is the process flow diagram (PFD) for a single power module. It depicts the design and control concepts, process equipment, and presents the flows and conditions for all streams entering and exiting a single power module contained within a power-module vessel.

Operating conditions shown on these drawings are for full-load, SOR operation at $15^{\circ} \mathrm{C}$ ambient air temperature and at sea level.

The process stream flows and conditions for the following other operating cases are shown on the PFDs. 


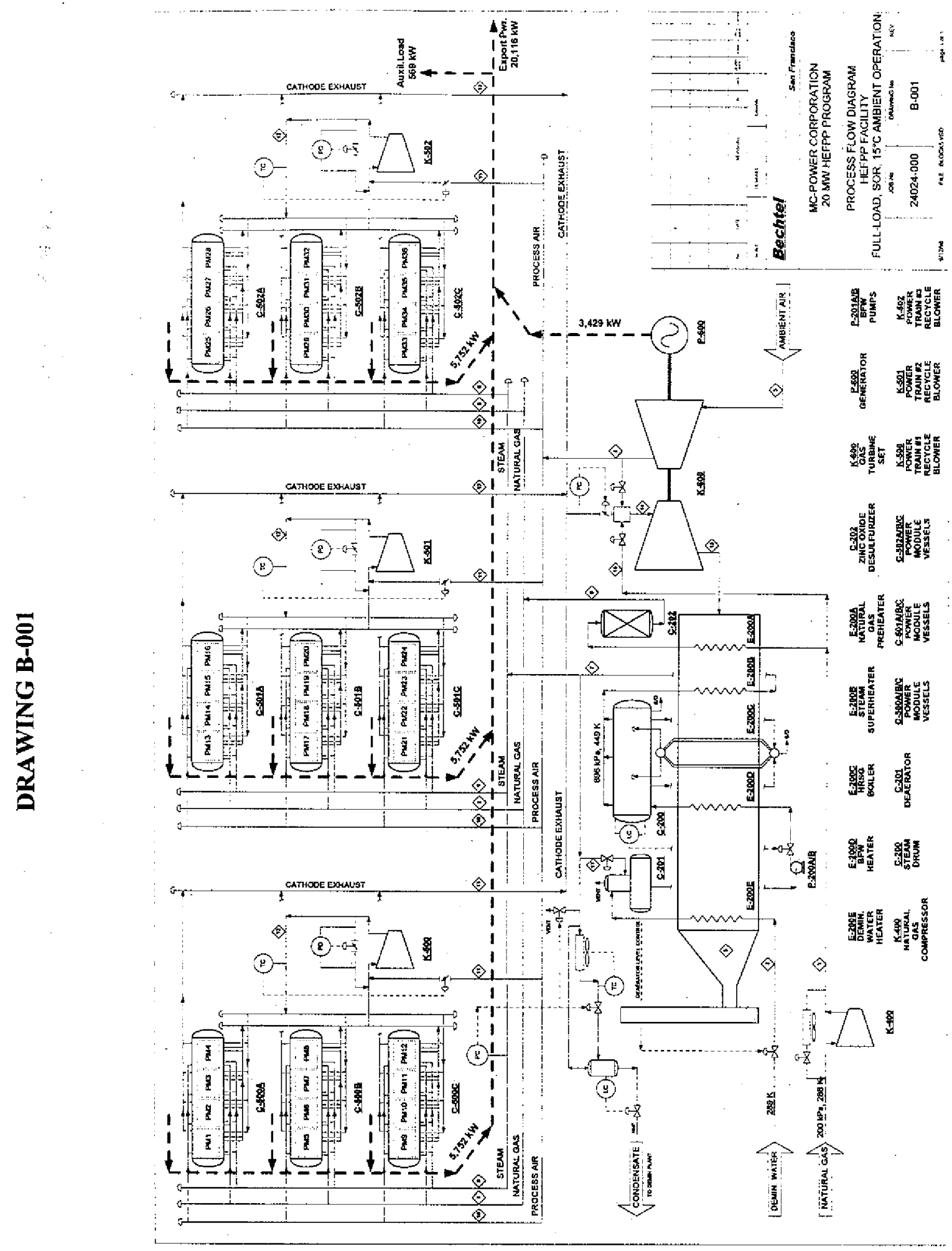




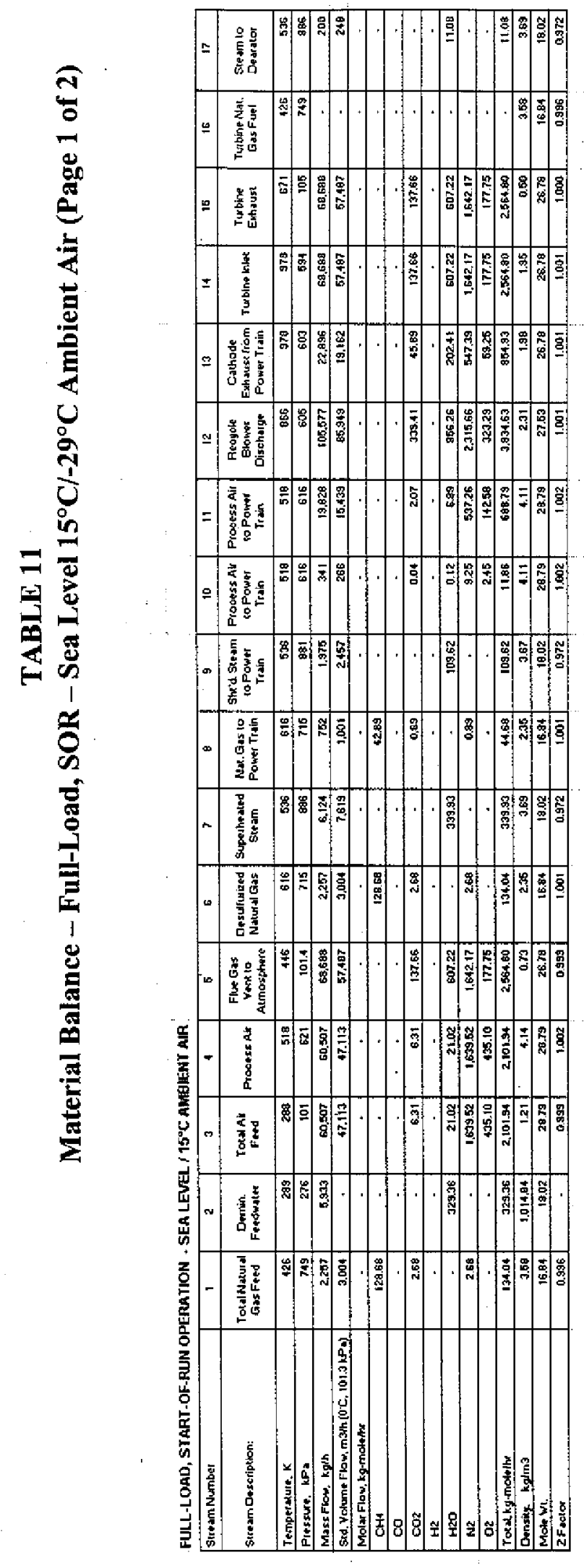

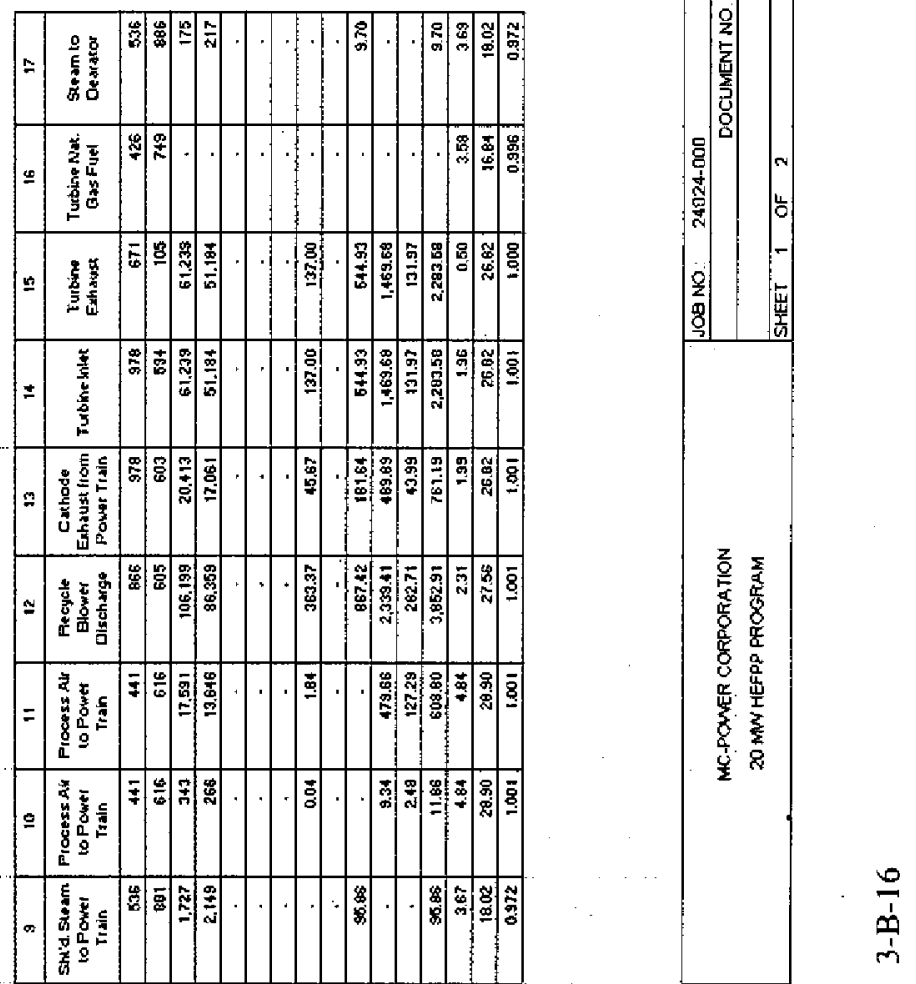

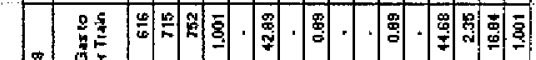

$\infty$

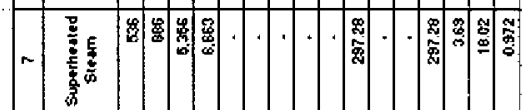

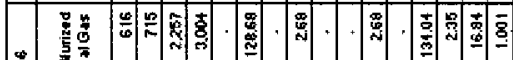

碗亮

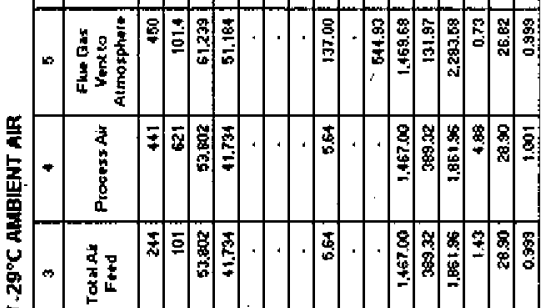

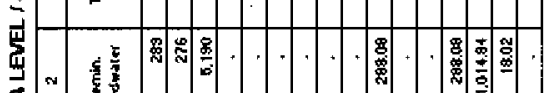

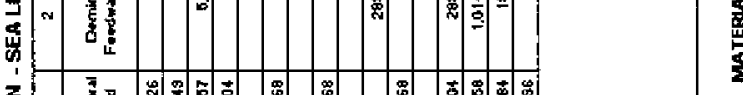
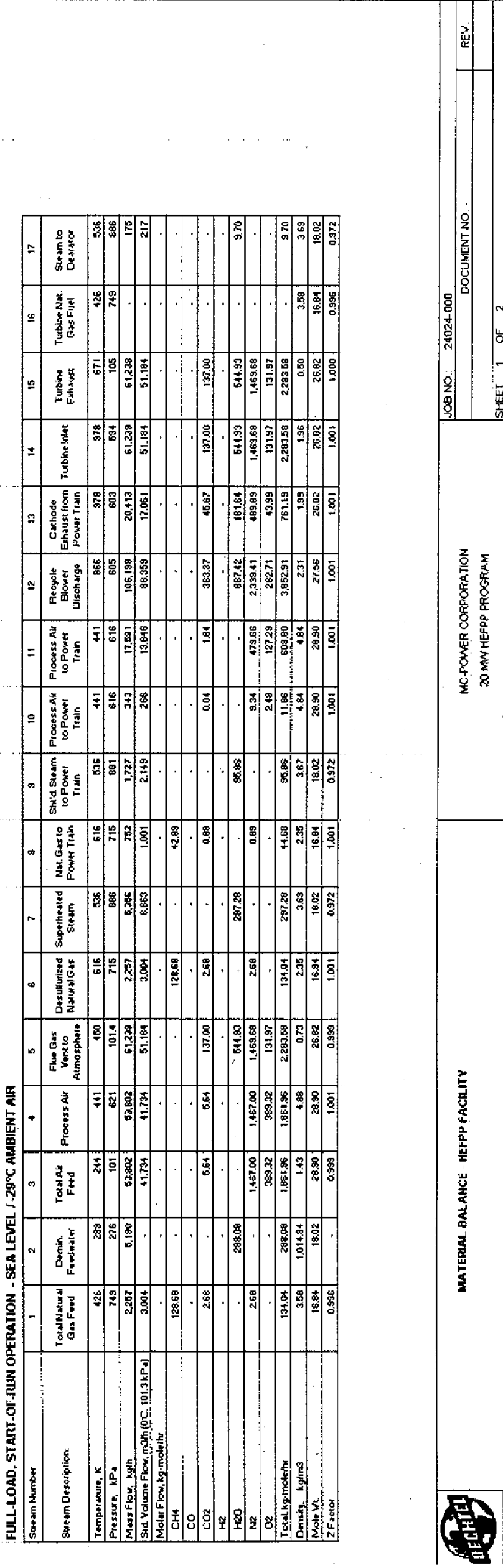


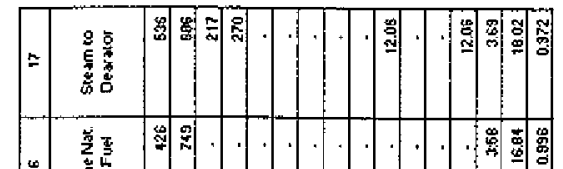

$\because \frac{1}{4}$

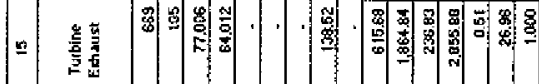

$=$ 旁

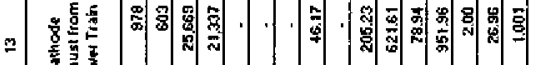

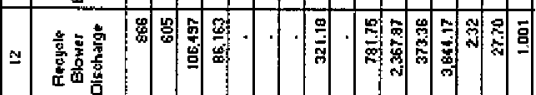

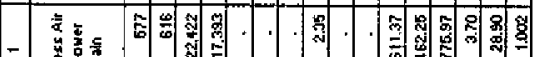

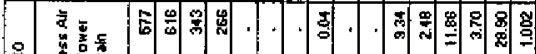

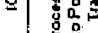

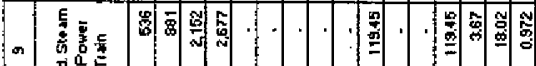

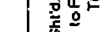

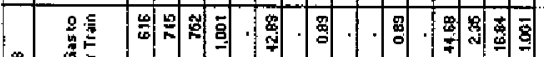

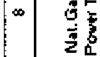

-2 童言

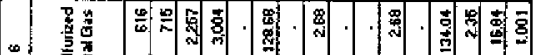

4

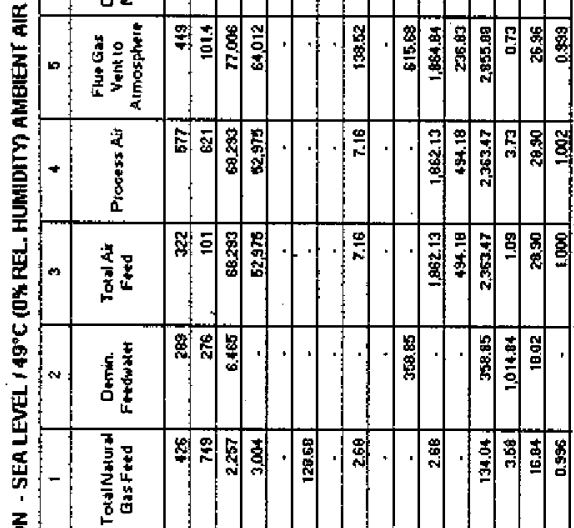

z.

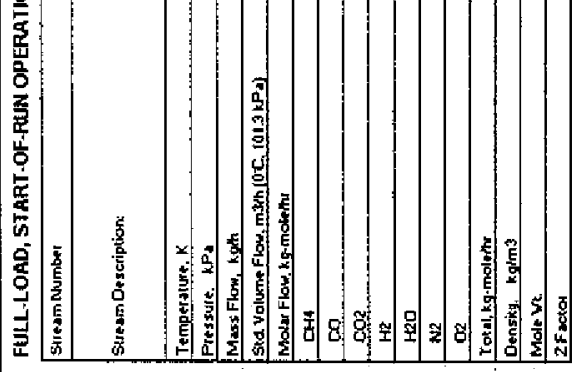

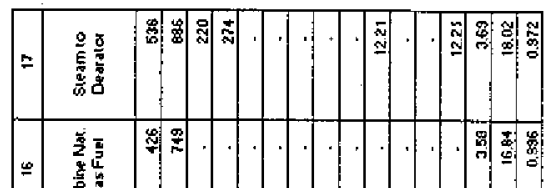

政

$=$ 衰弯

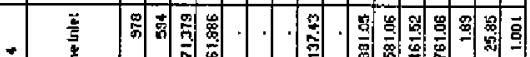

$-$

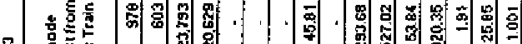

$=2 \frac{3}{3}$

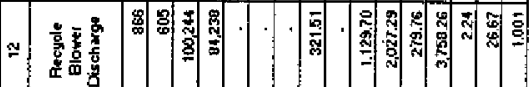

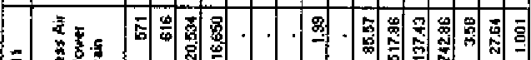

$=\frac{1}{3}$

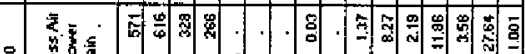

$=\frac{10}{20}$

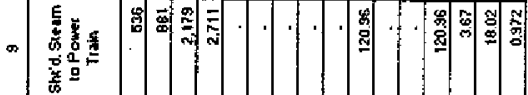

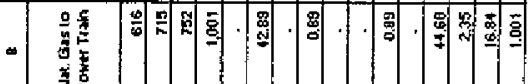

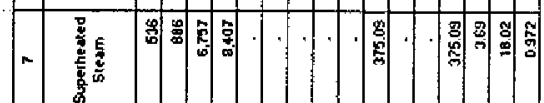

- 敢

落

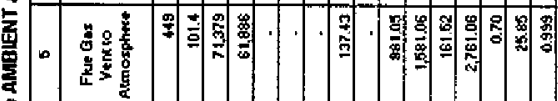

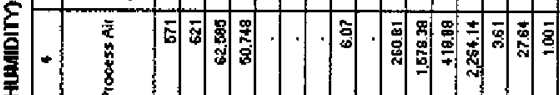

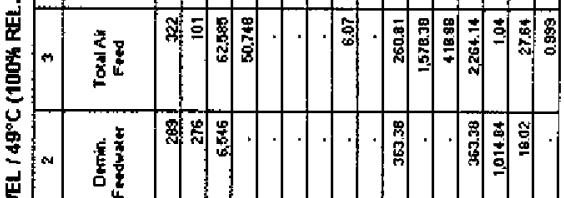

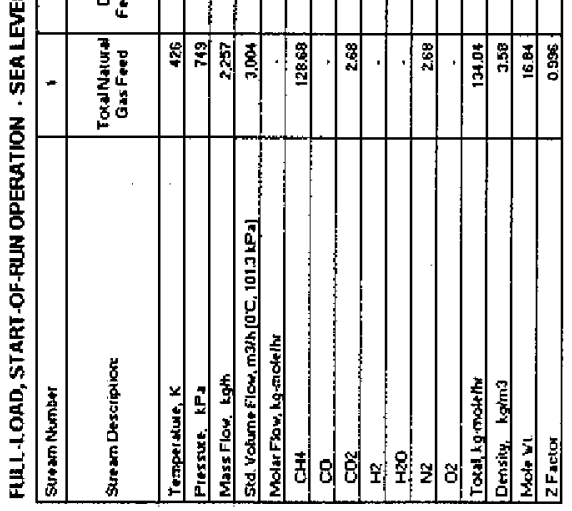

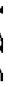



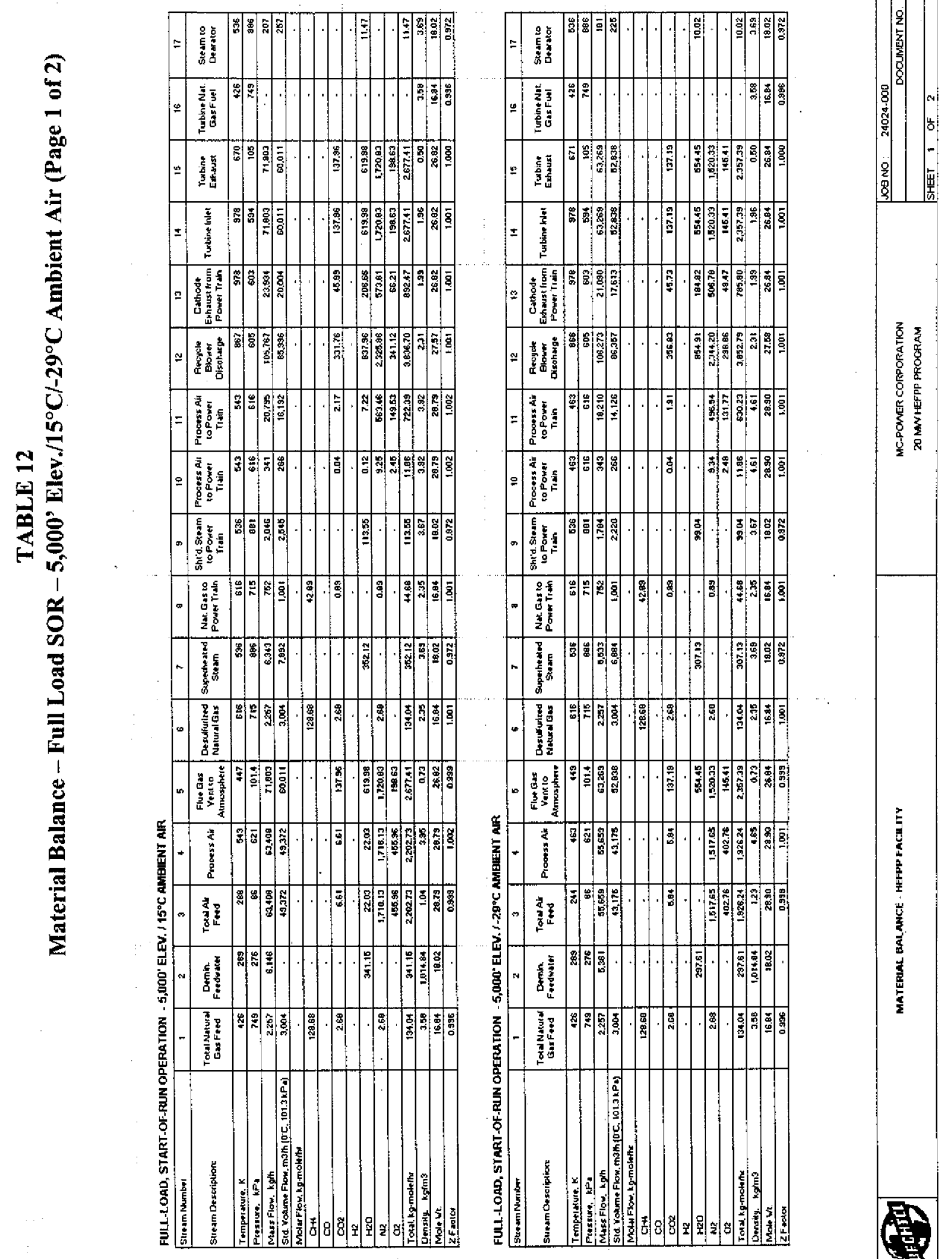

$\frac{\infty}{n}$ 


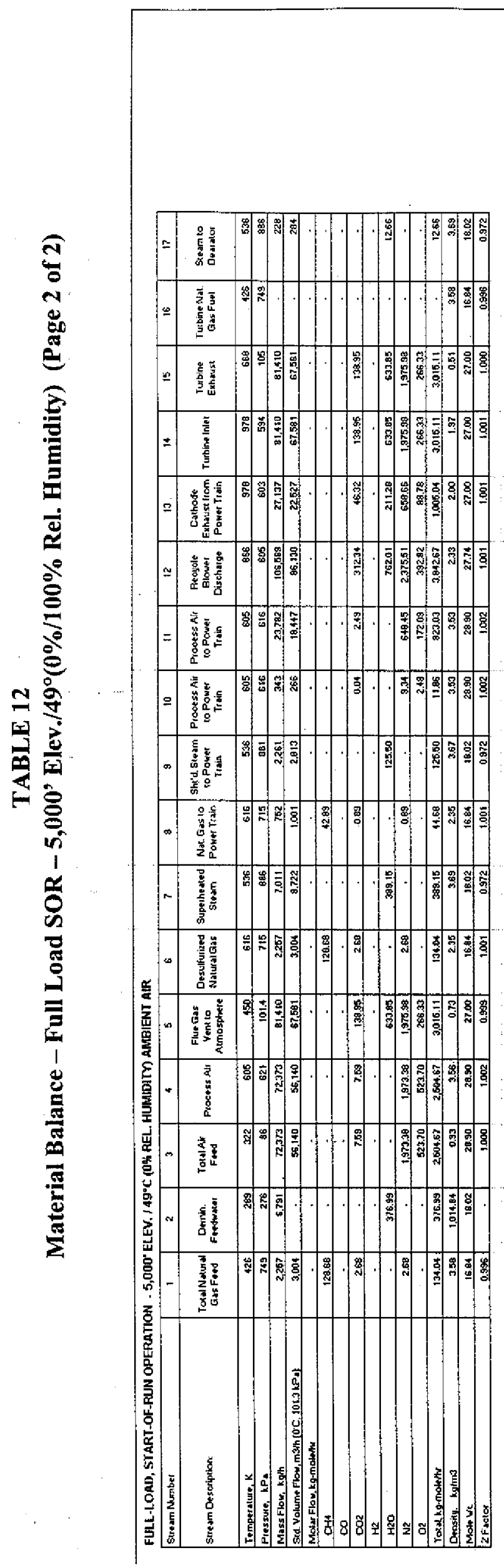

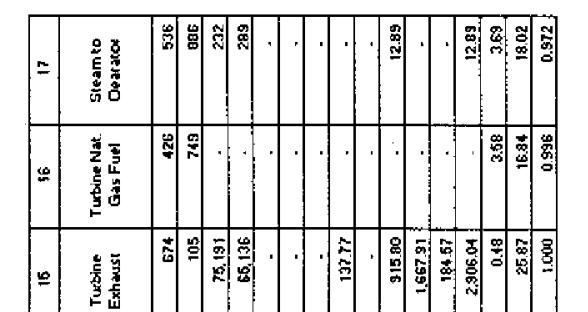

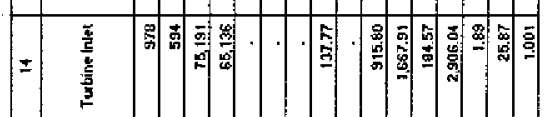

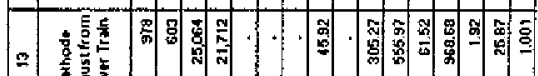

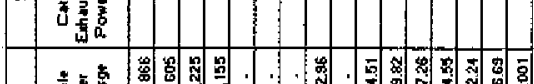

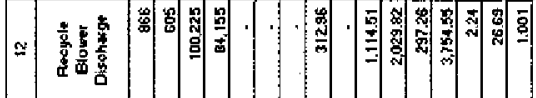

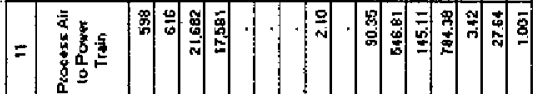

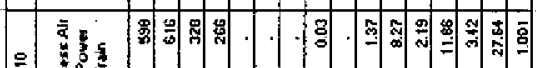

$=8$

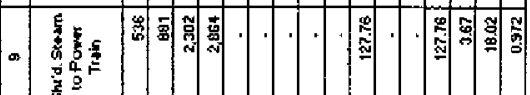

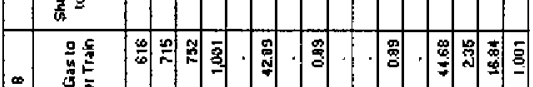

- $\frac{3}{2}$

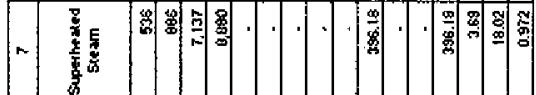

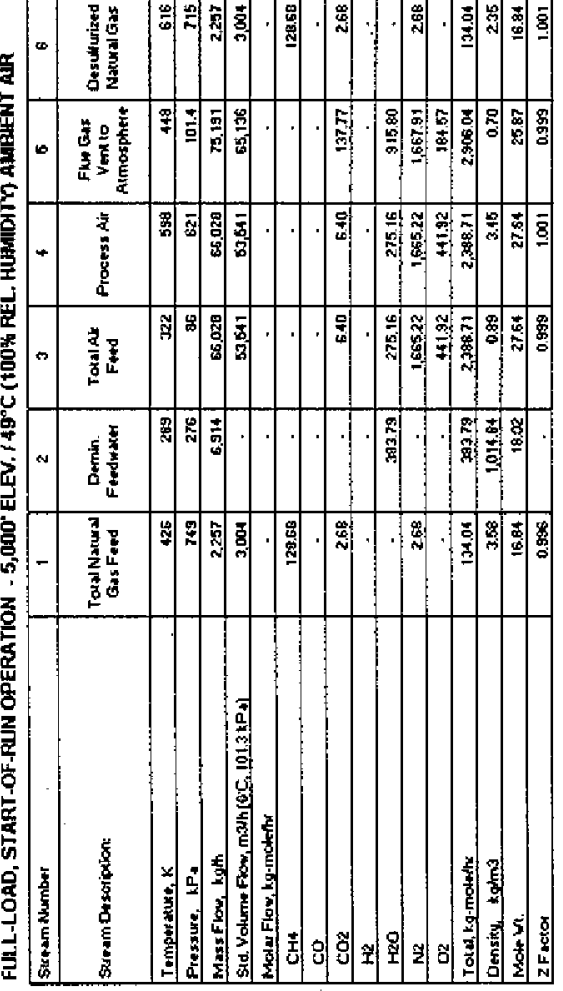



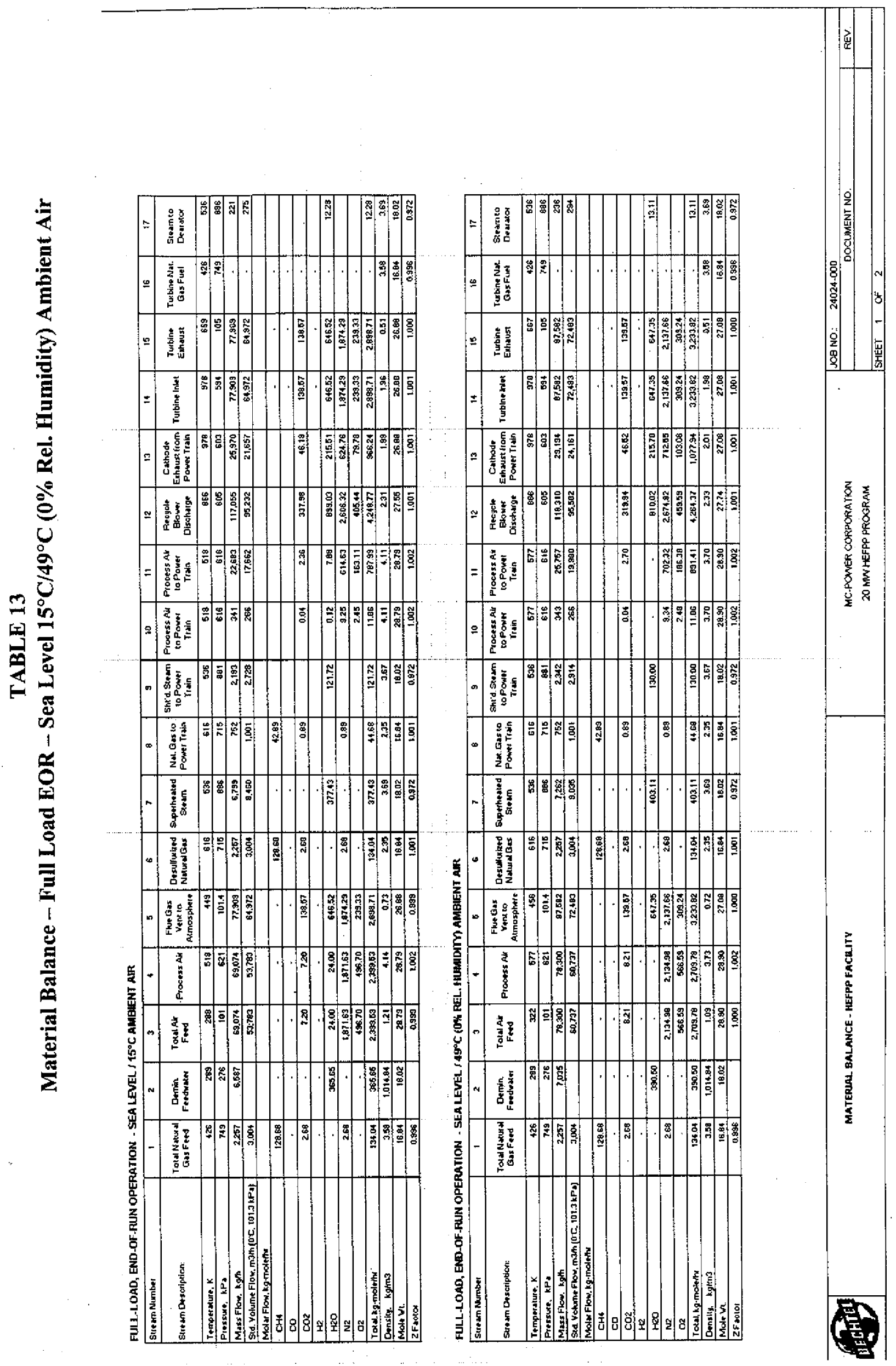


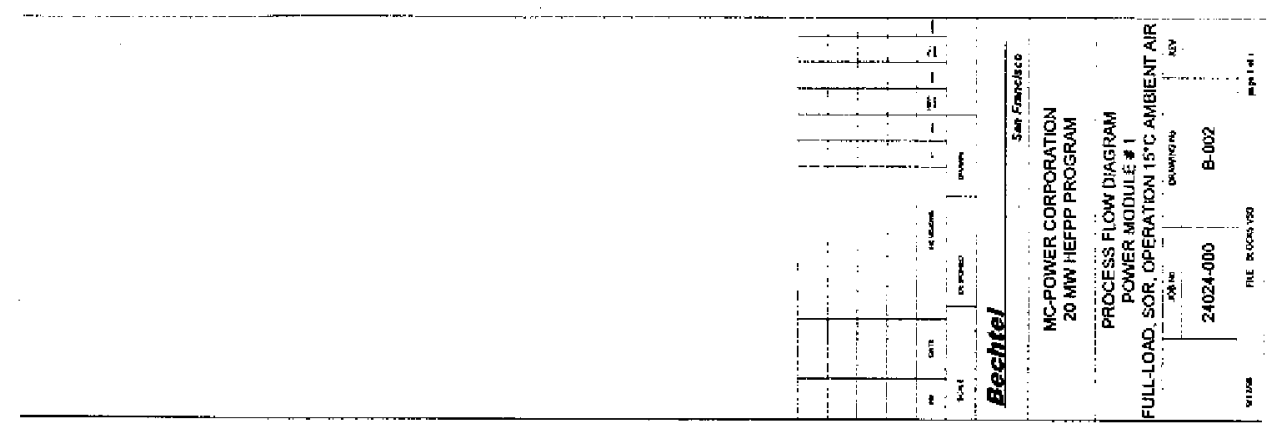

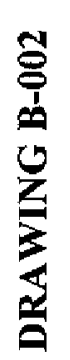

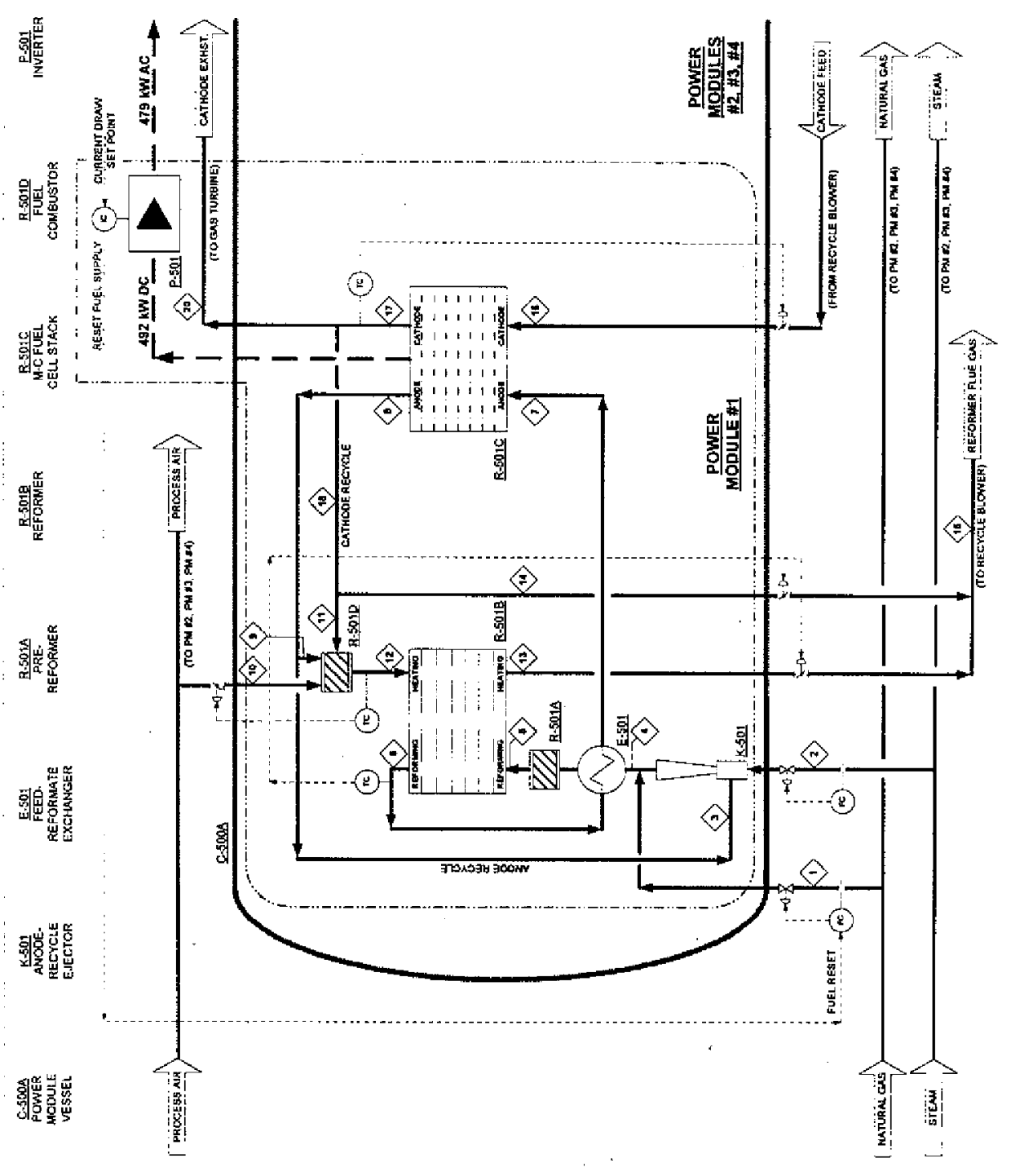

$\ddot{\ddot{n}}$ 

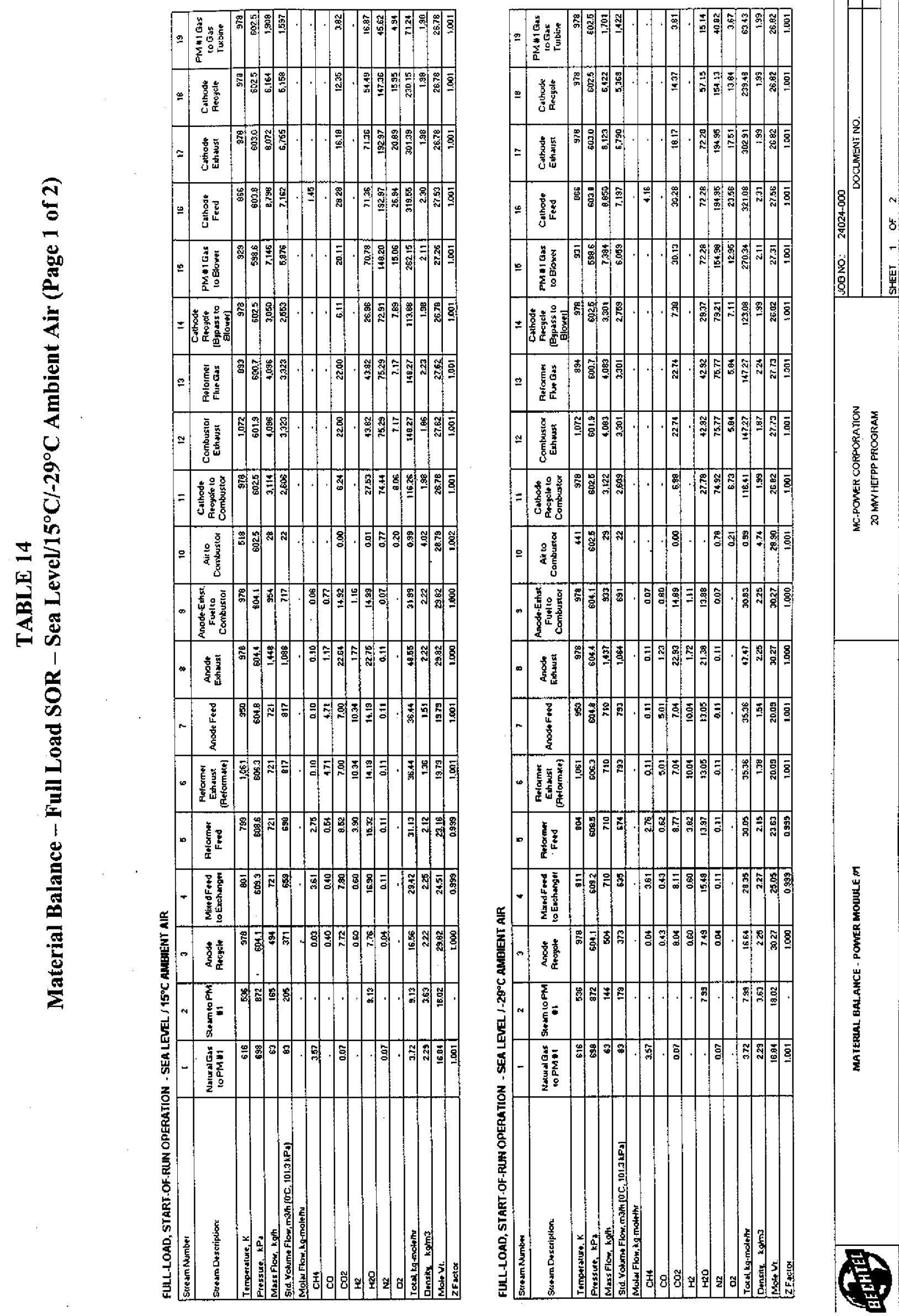


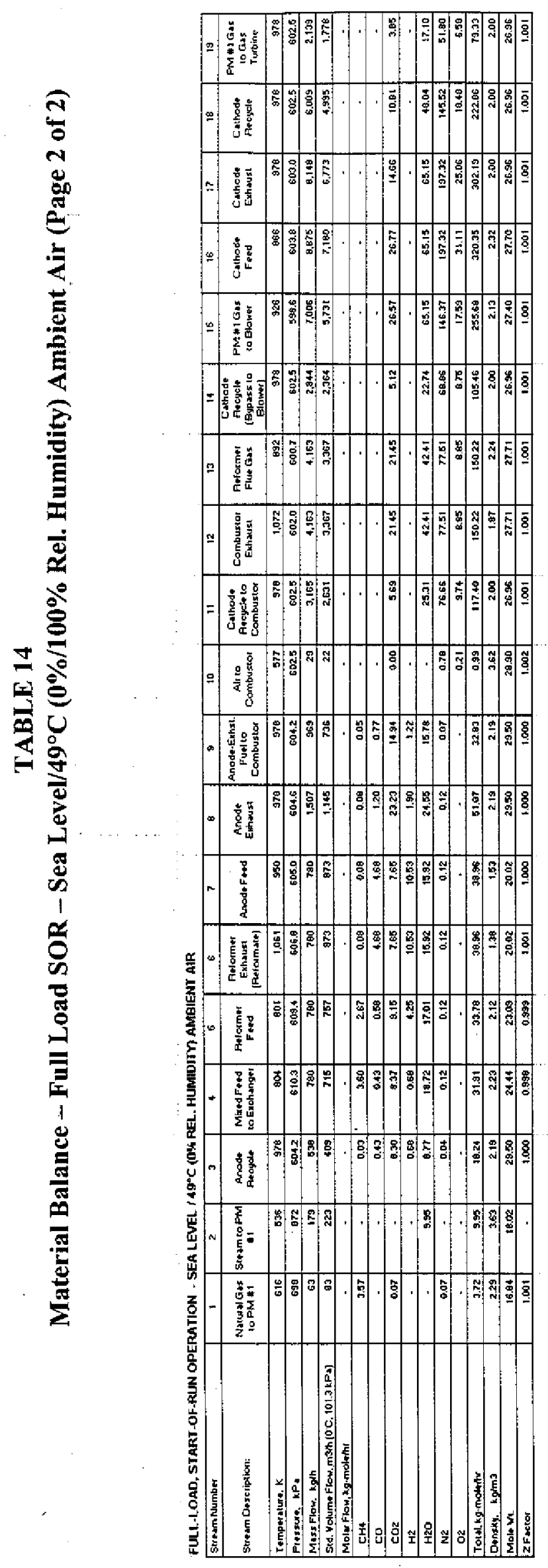

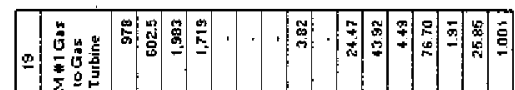

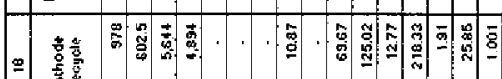

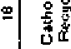

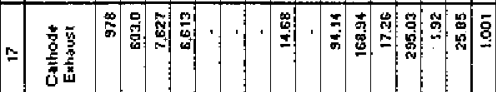

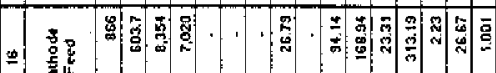
o

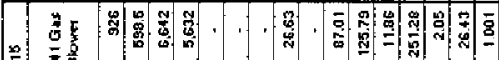

部

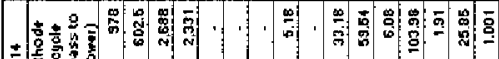

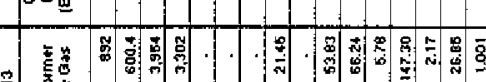

$\Rightarrow \frac{1}{\frac{1}{i n}}$

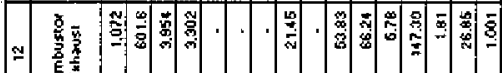

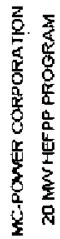

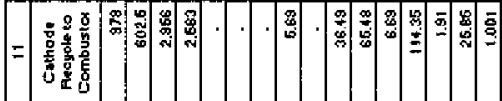

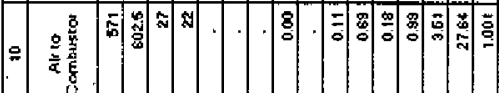

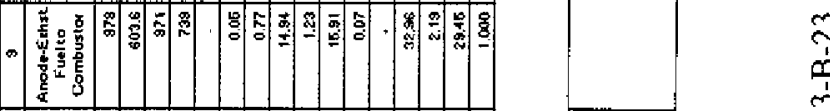

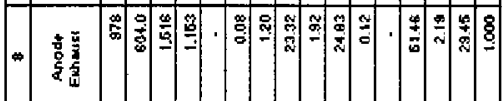

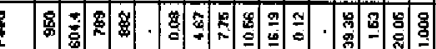

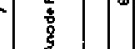

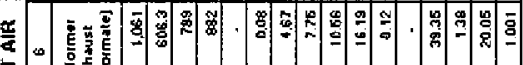

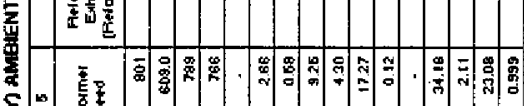

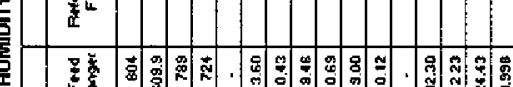

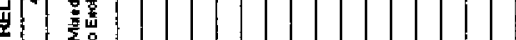

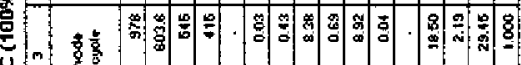

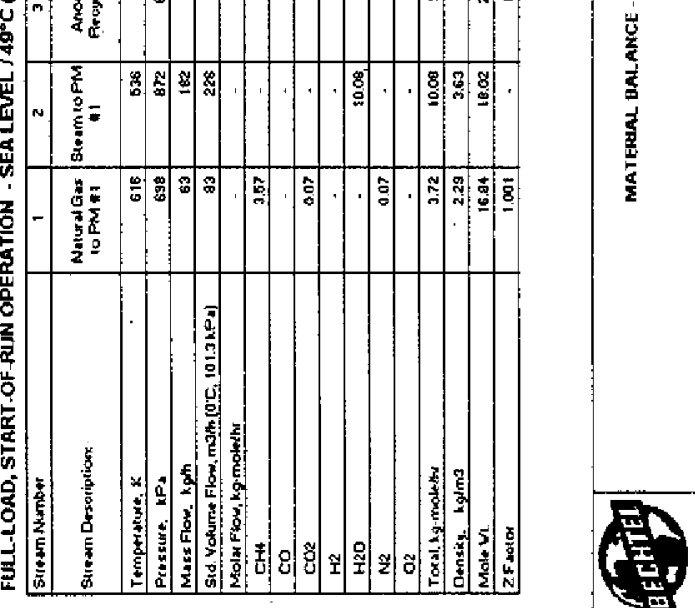

in 

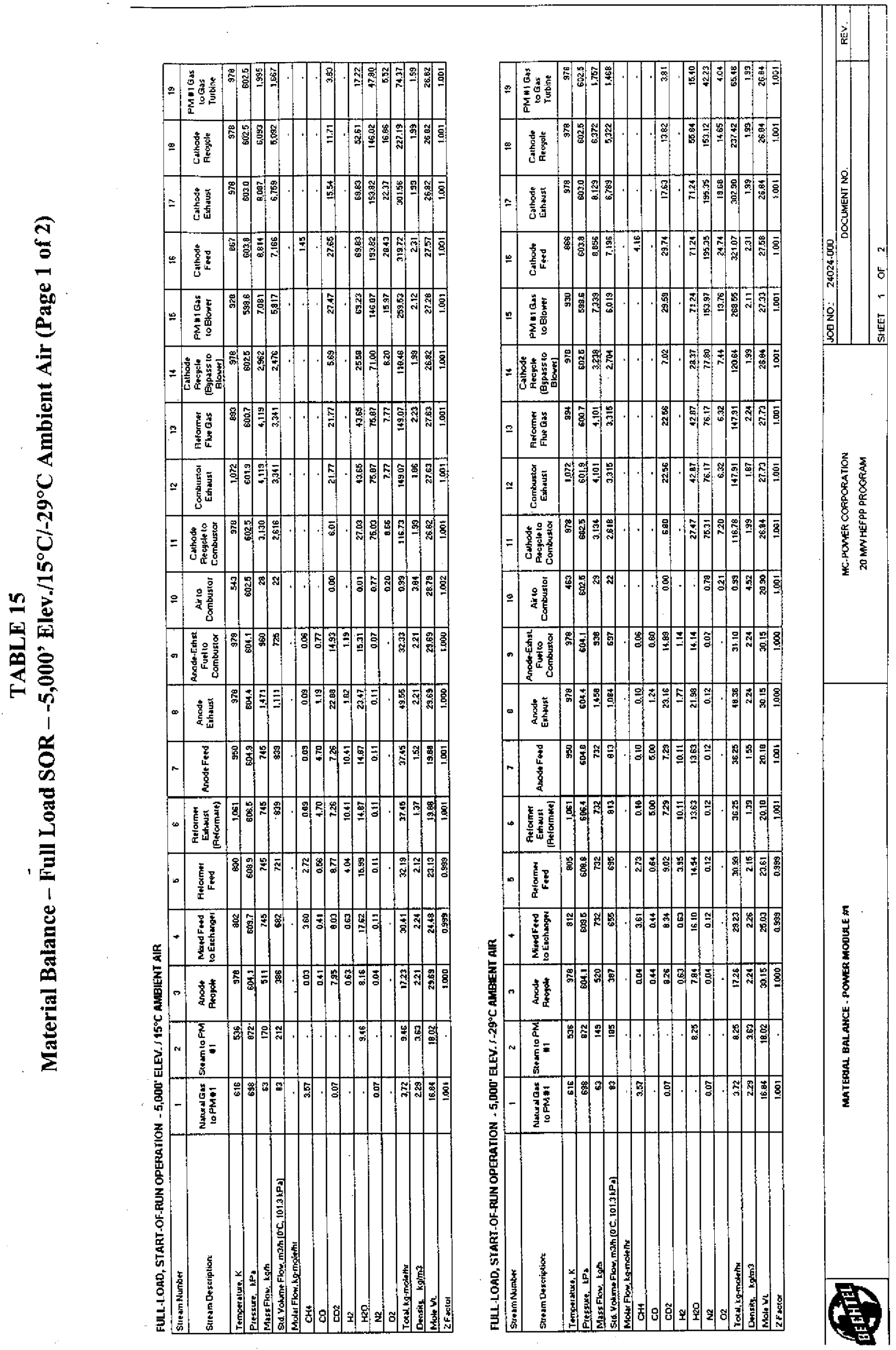

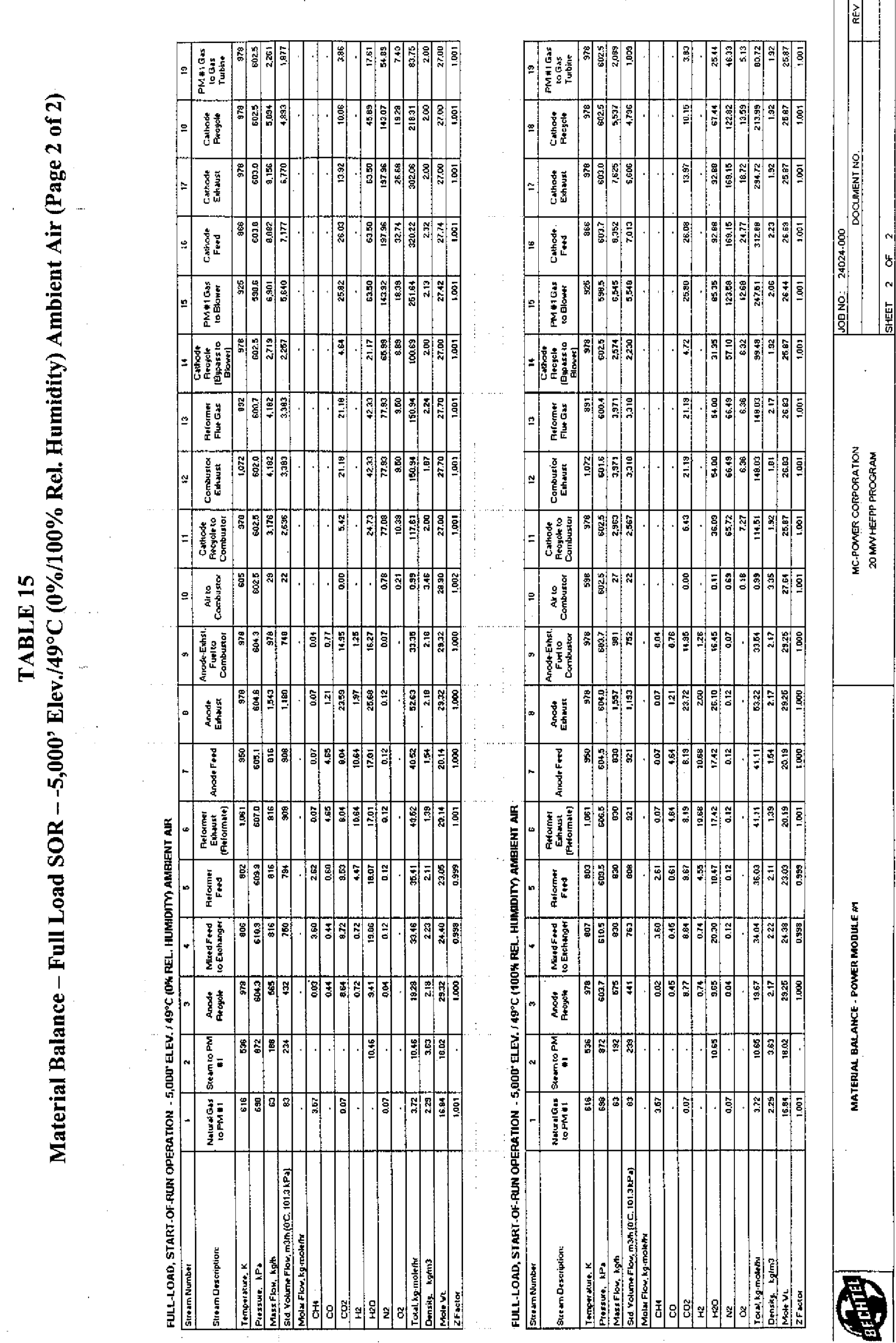

ஸे 

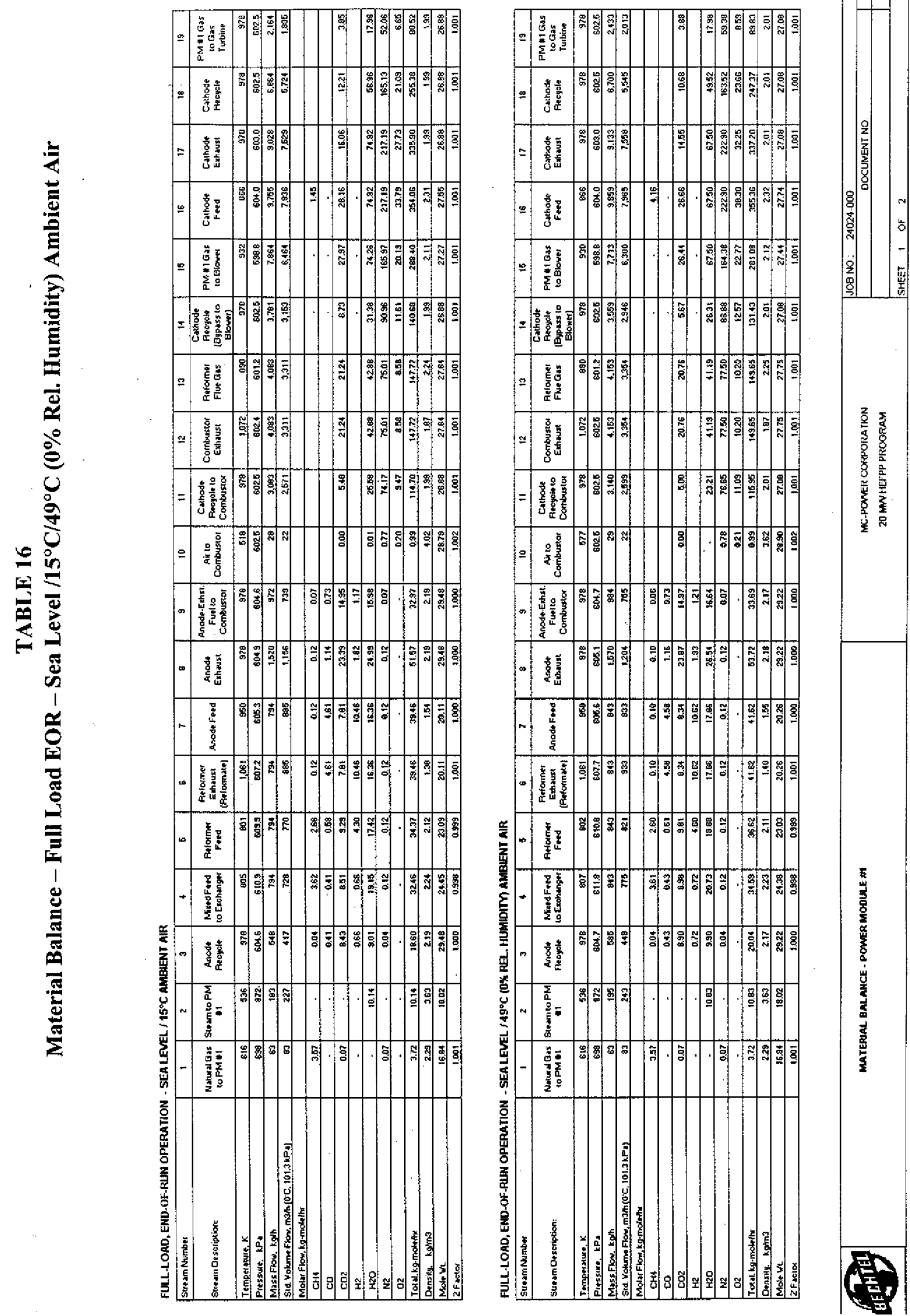

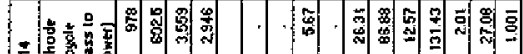

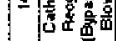

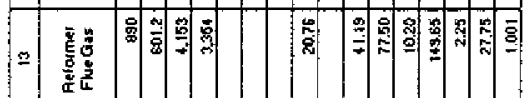

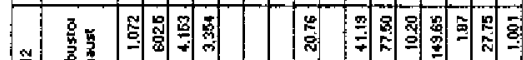
- 索

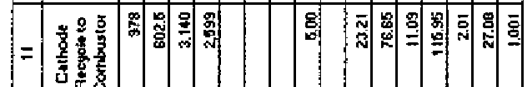
2 $=12$

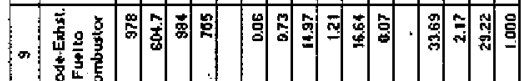

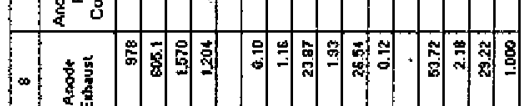

$\frac{0}{9}$

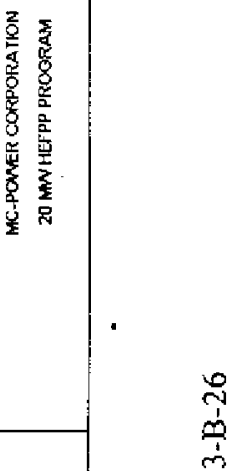

1 高 1

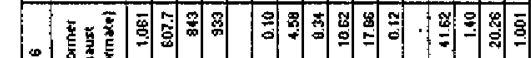

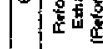

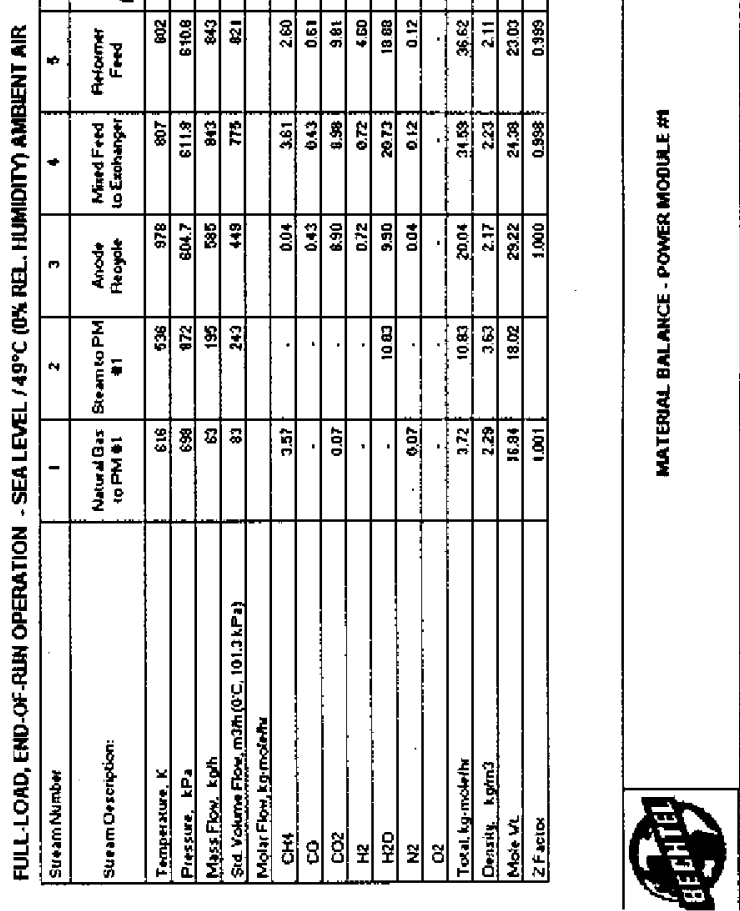



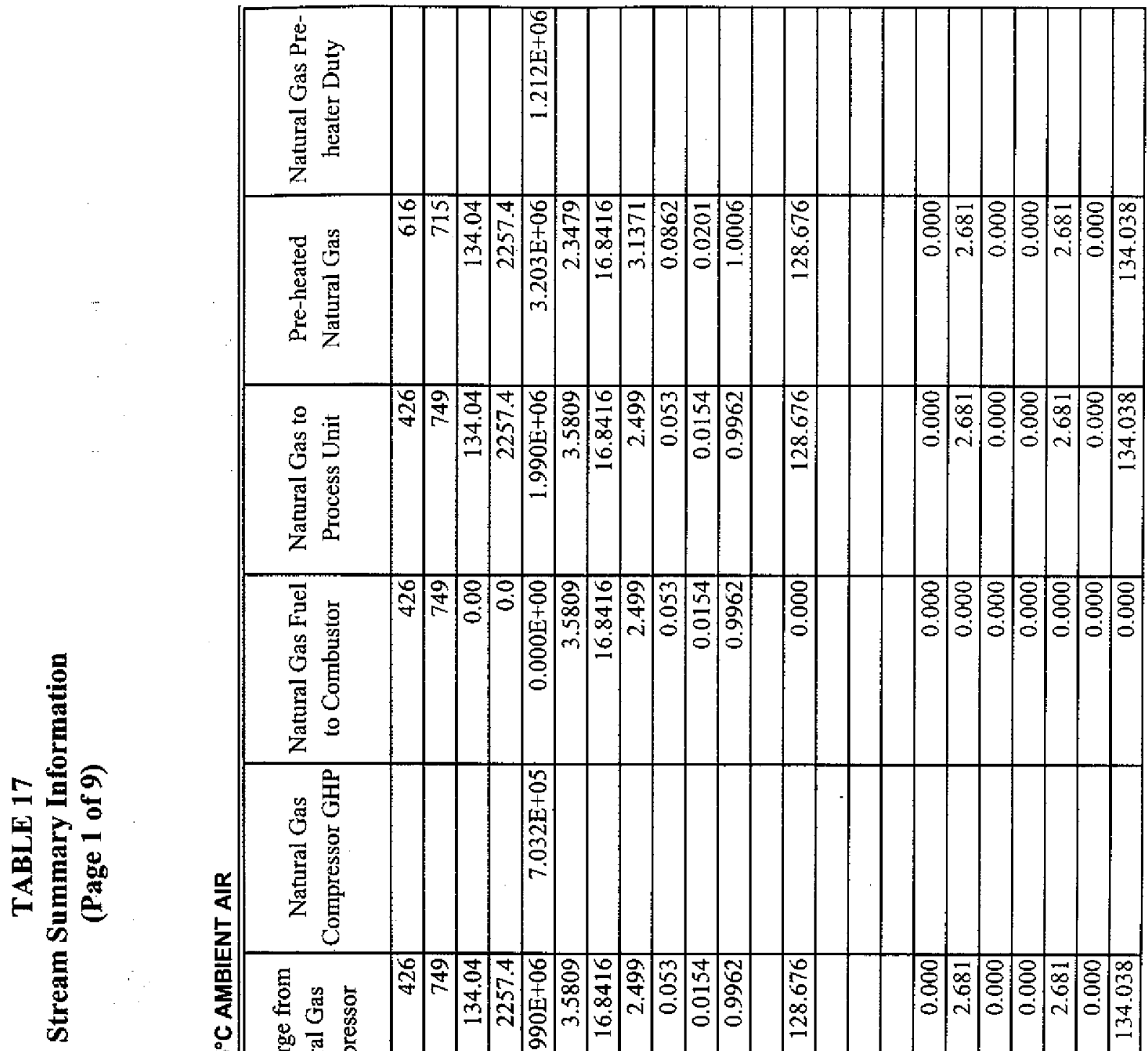

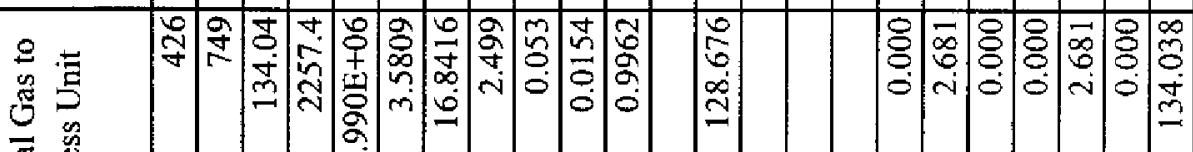

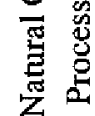

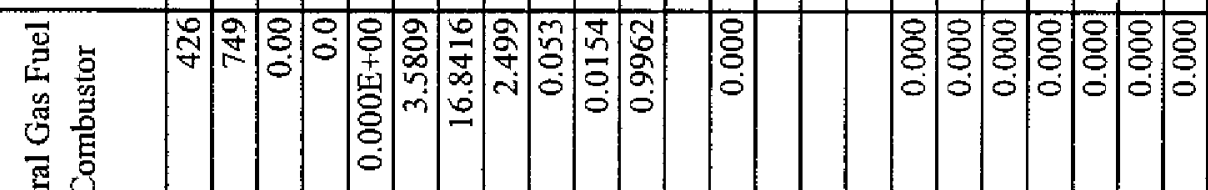

敢

产

总志

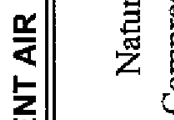

$\frac{\mathrm{m}}{\mathrm{m}}$

范

\begin{tabular}{lll}
\multirow{2}{*}{} & 0 & 0 \\
0 & 0 \\
0
\end{tabular}

丞荿

พ

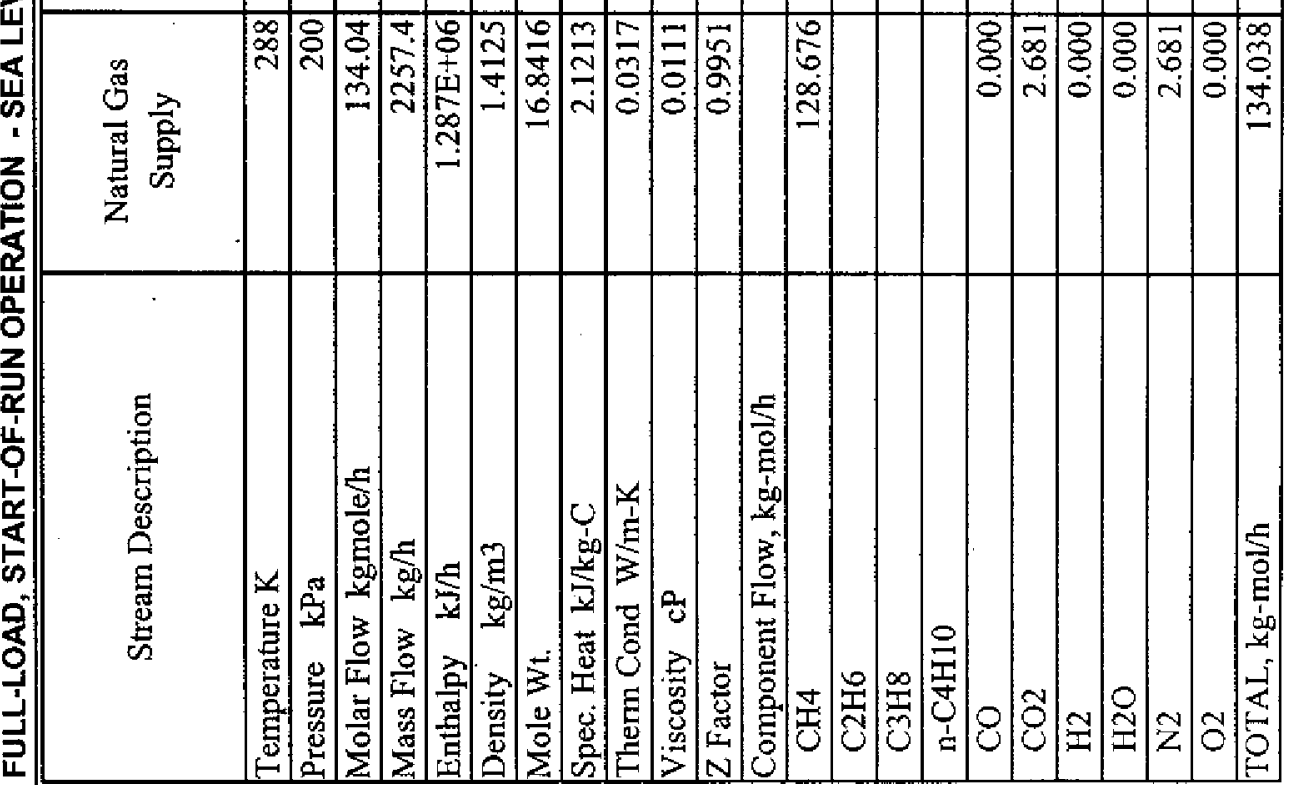




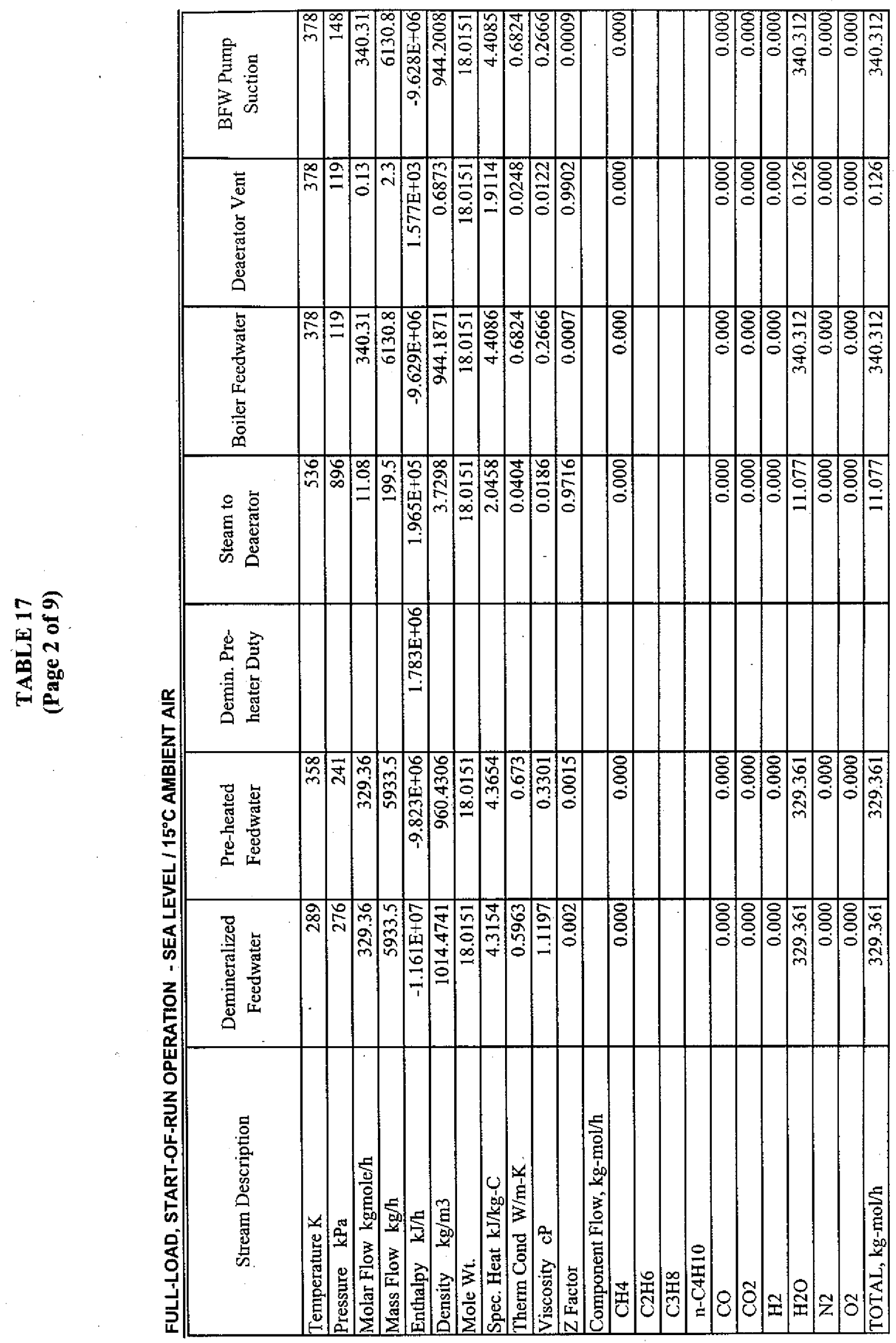

$\frac{\infty}{d}$ 


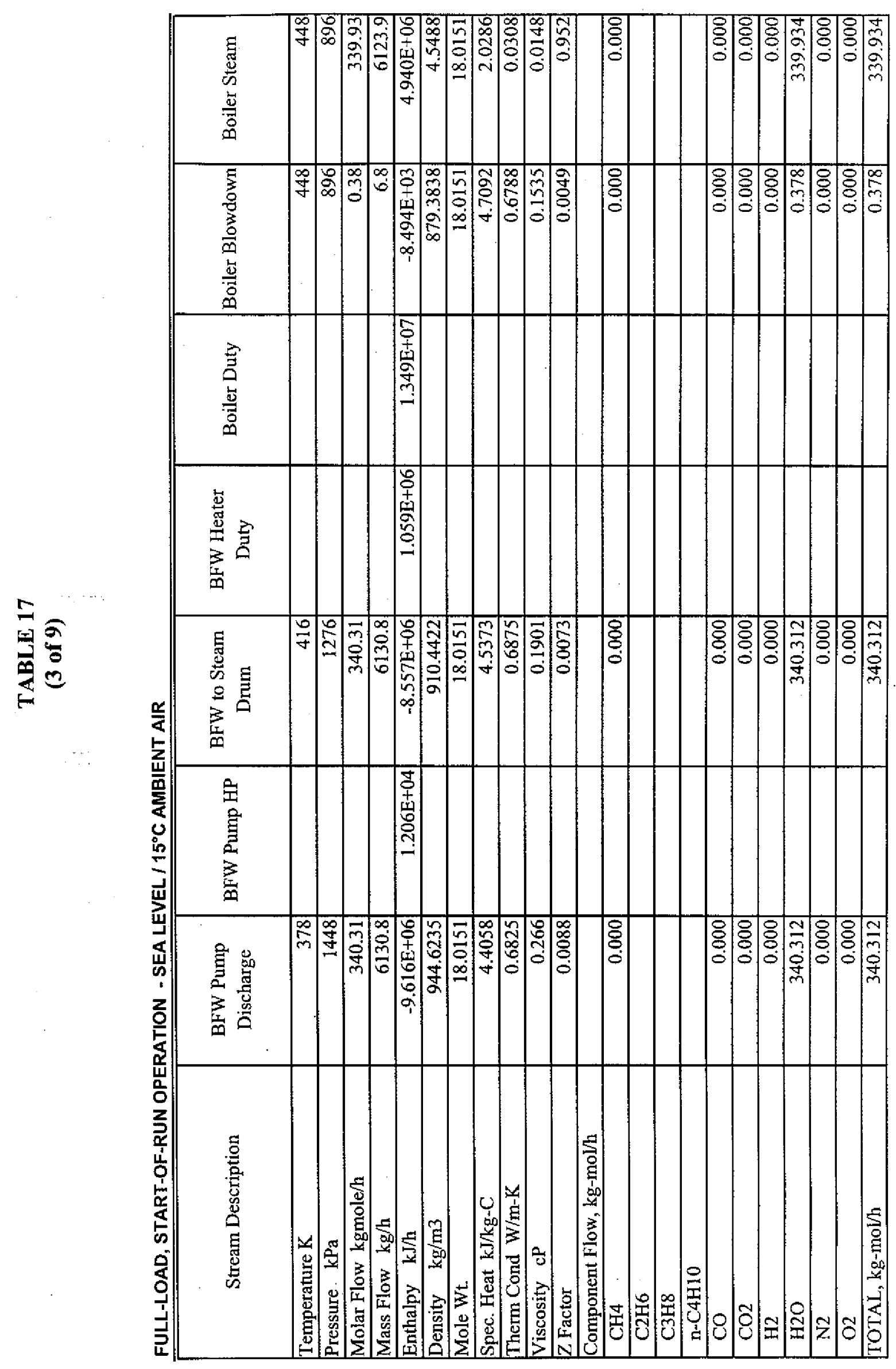




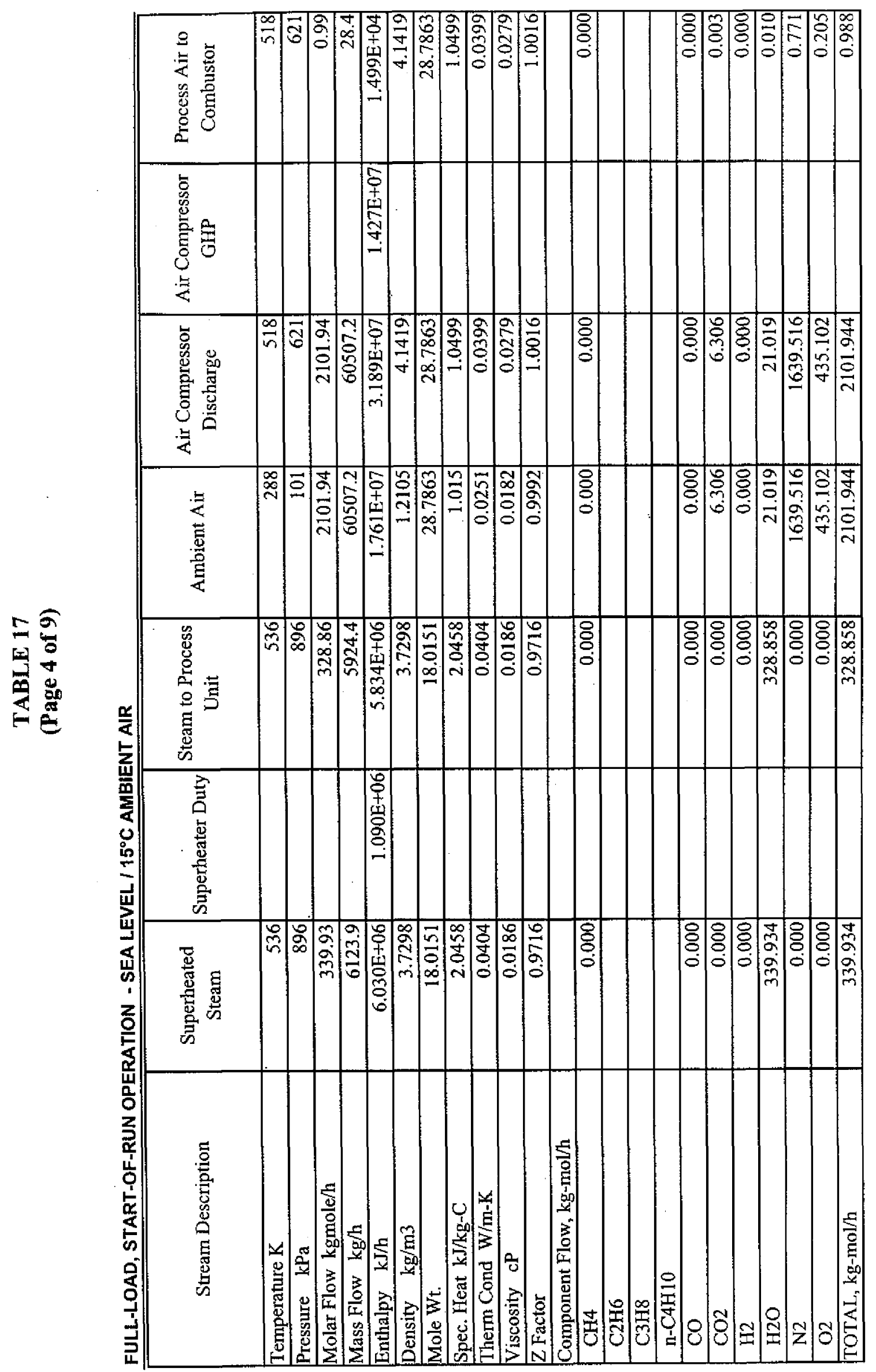




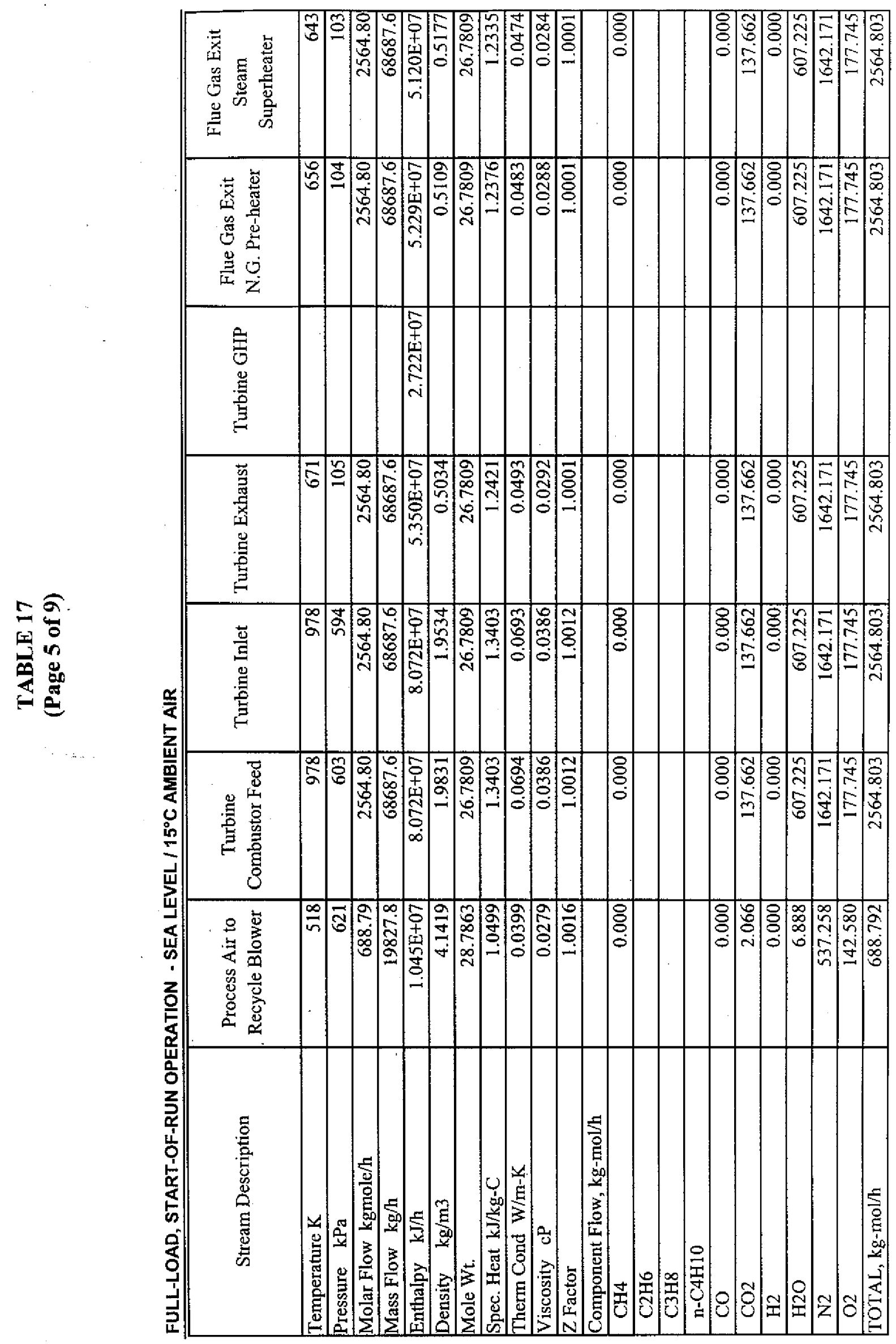




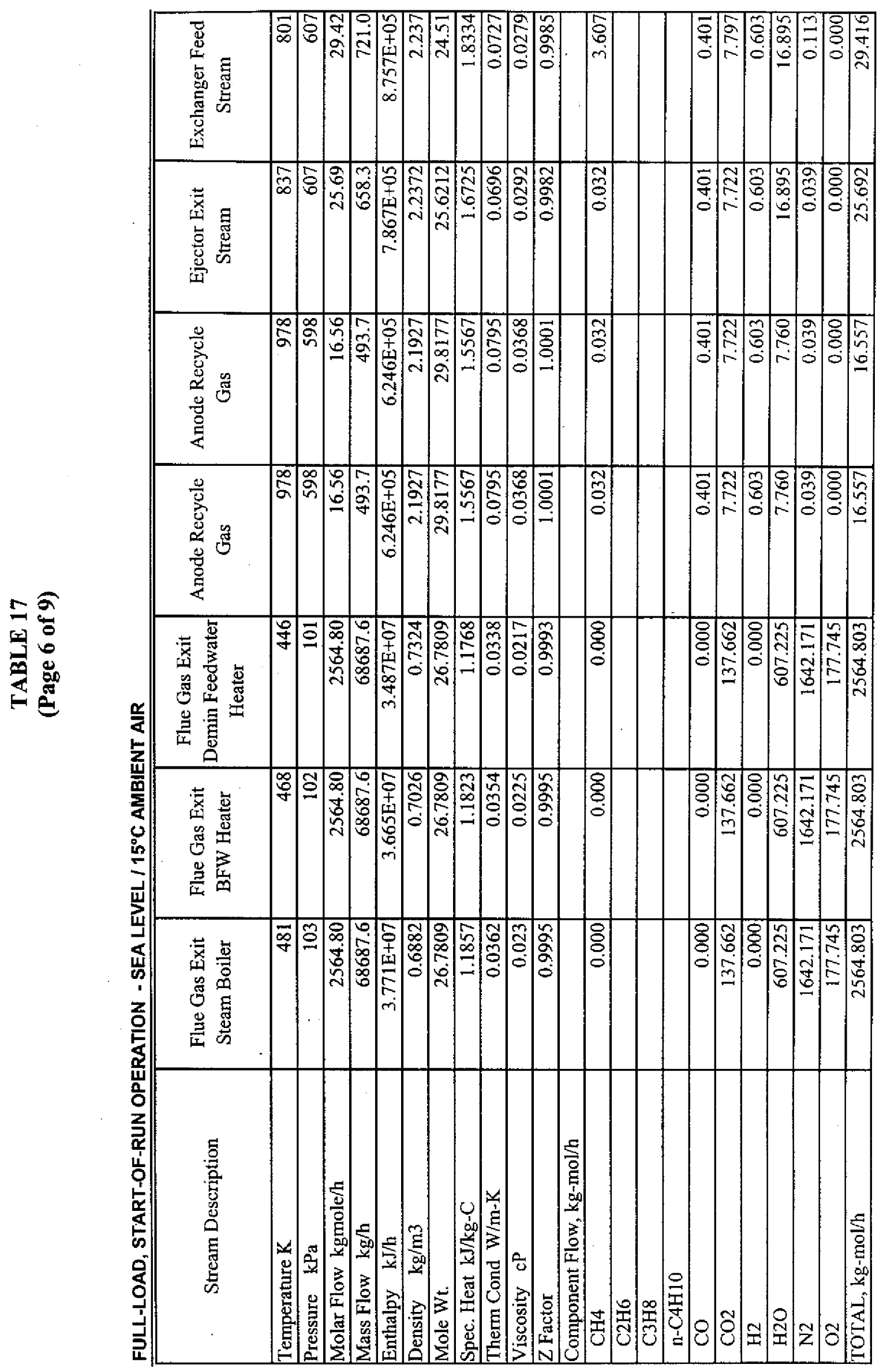




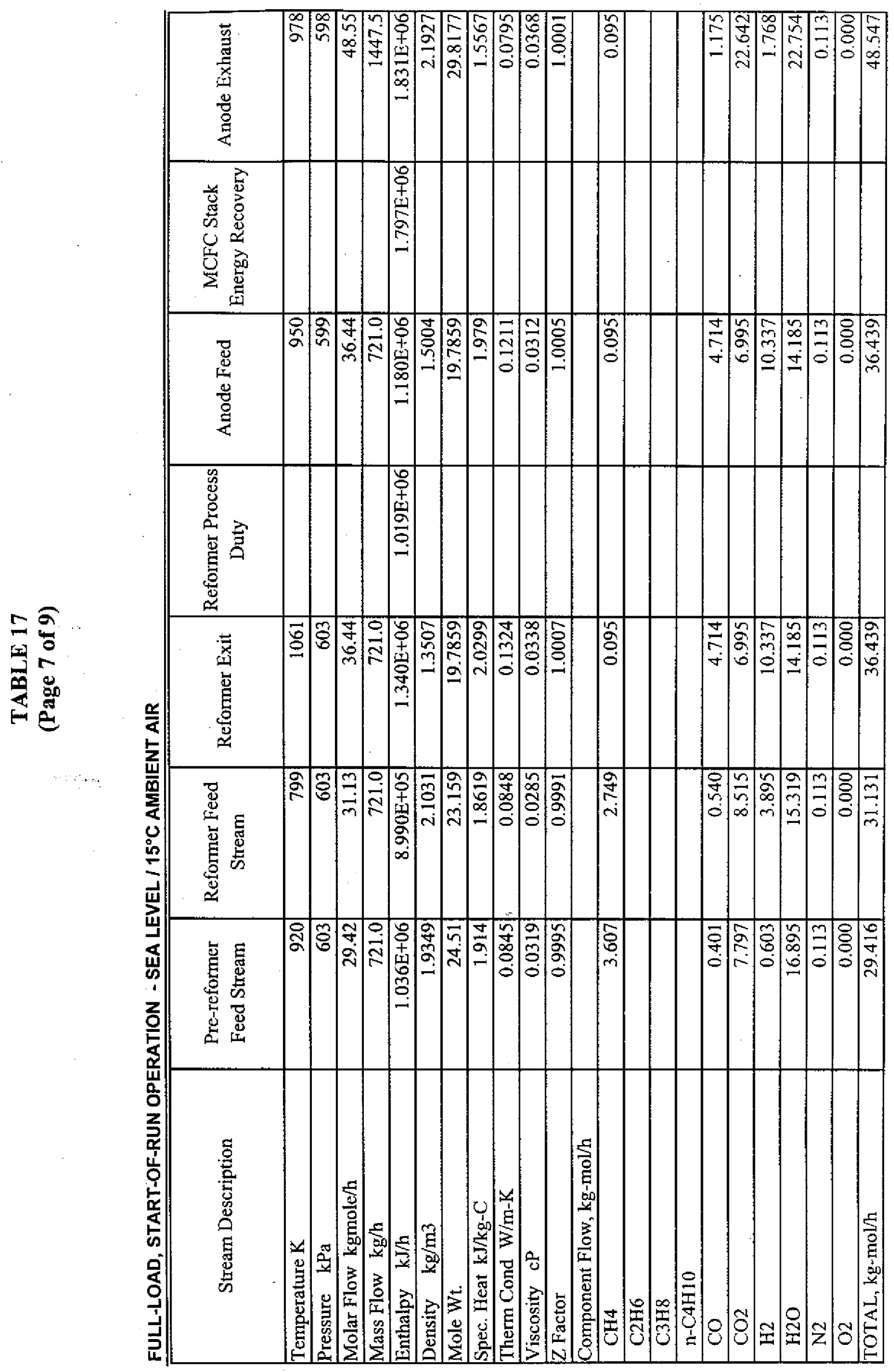




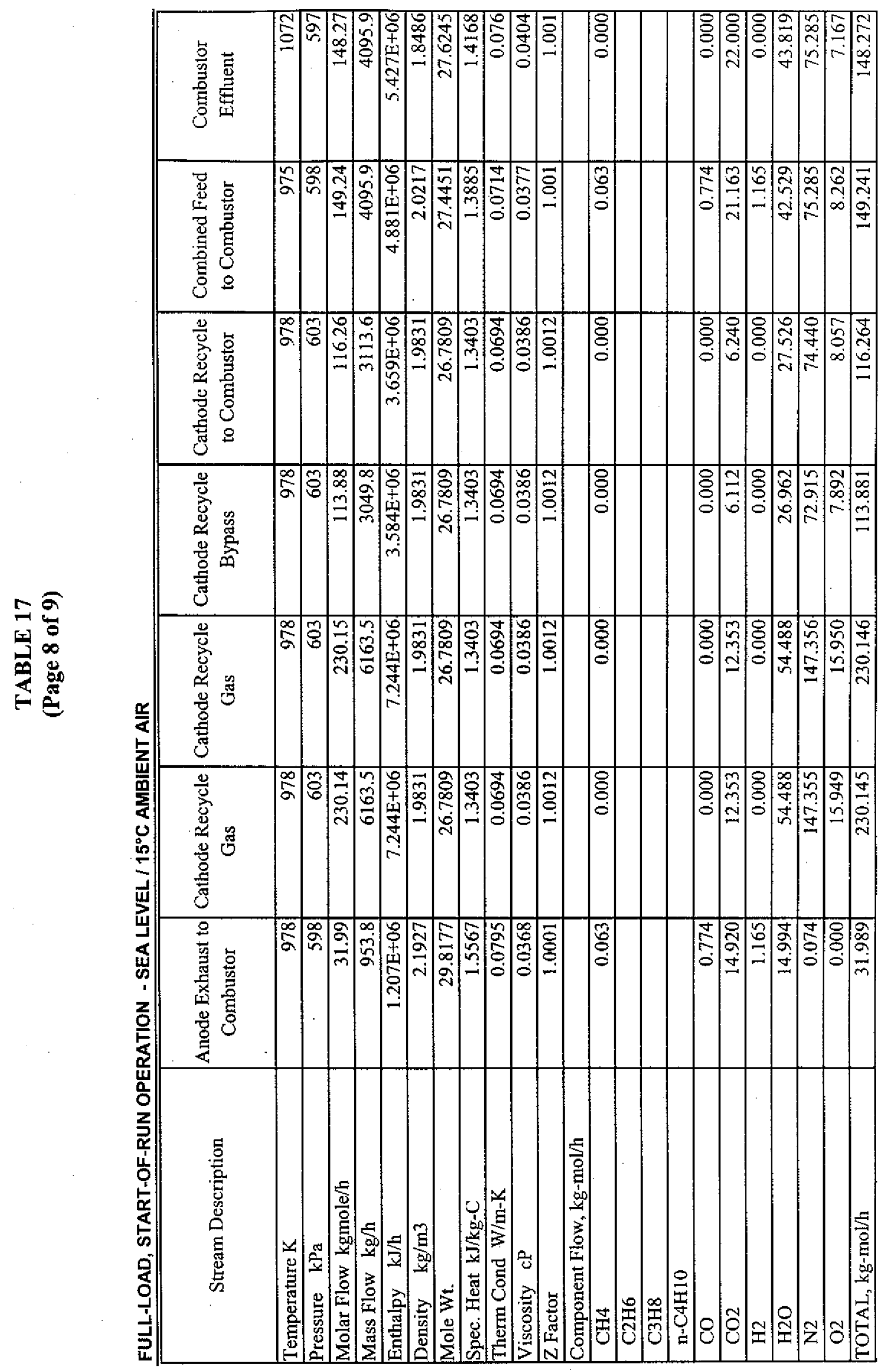




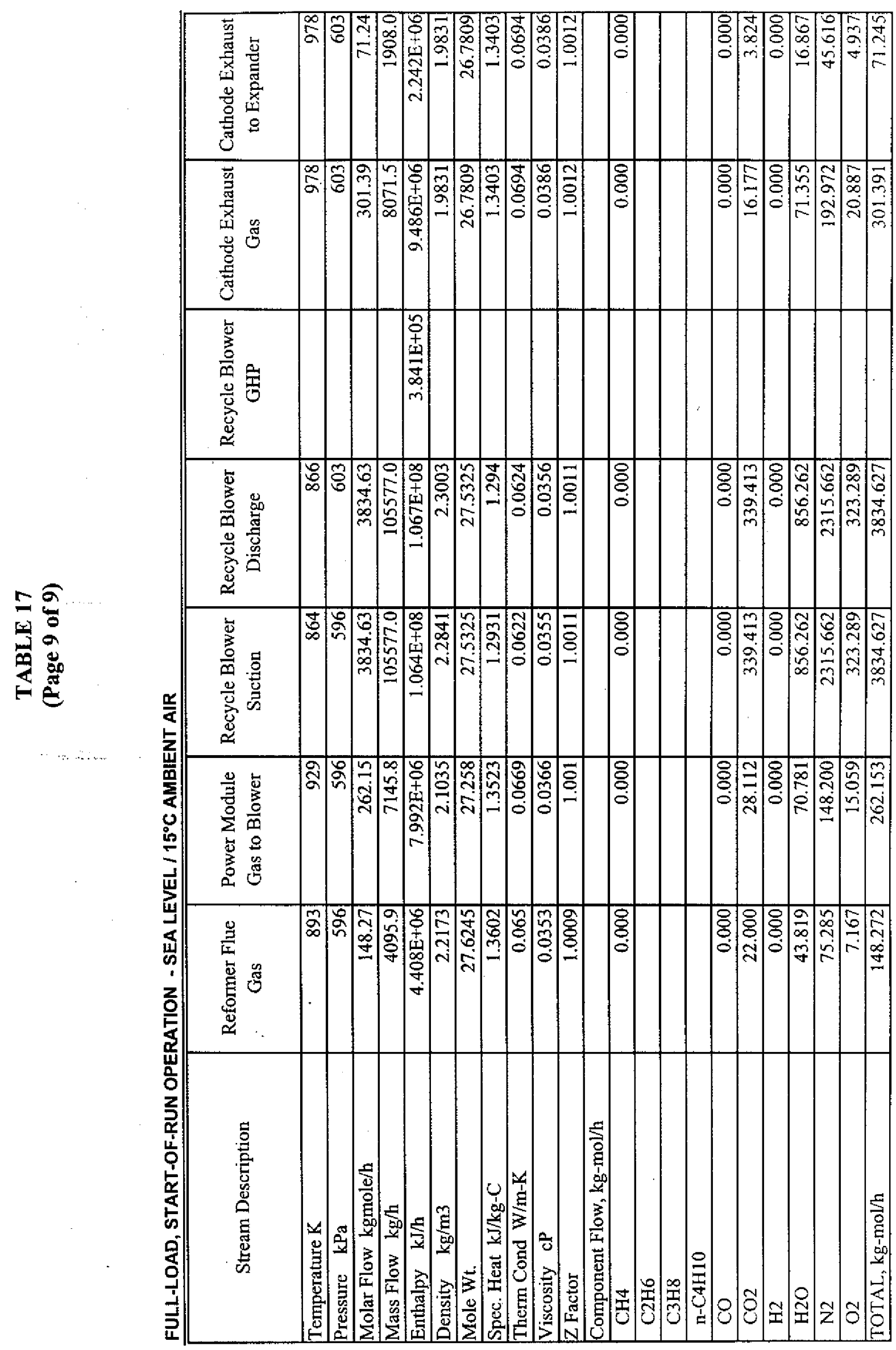




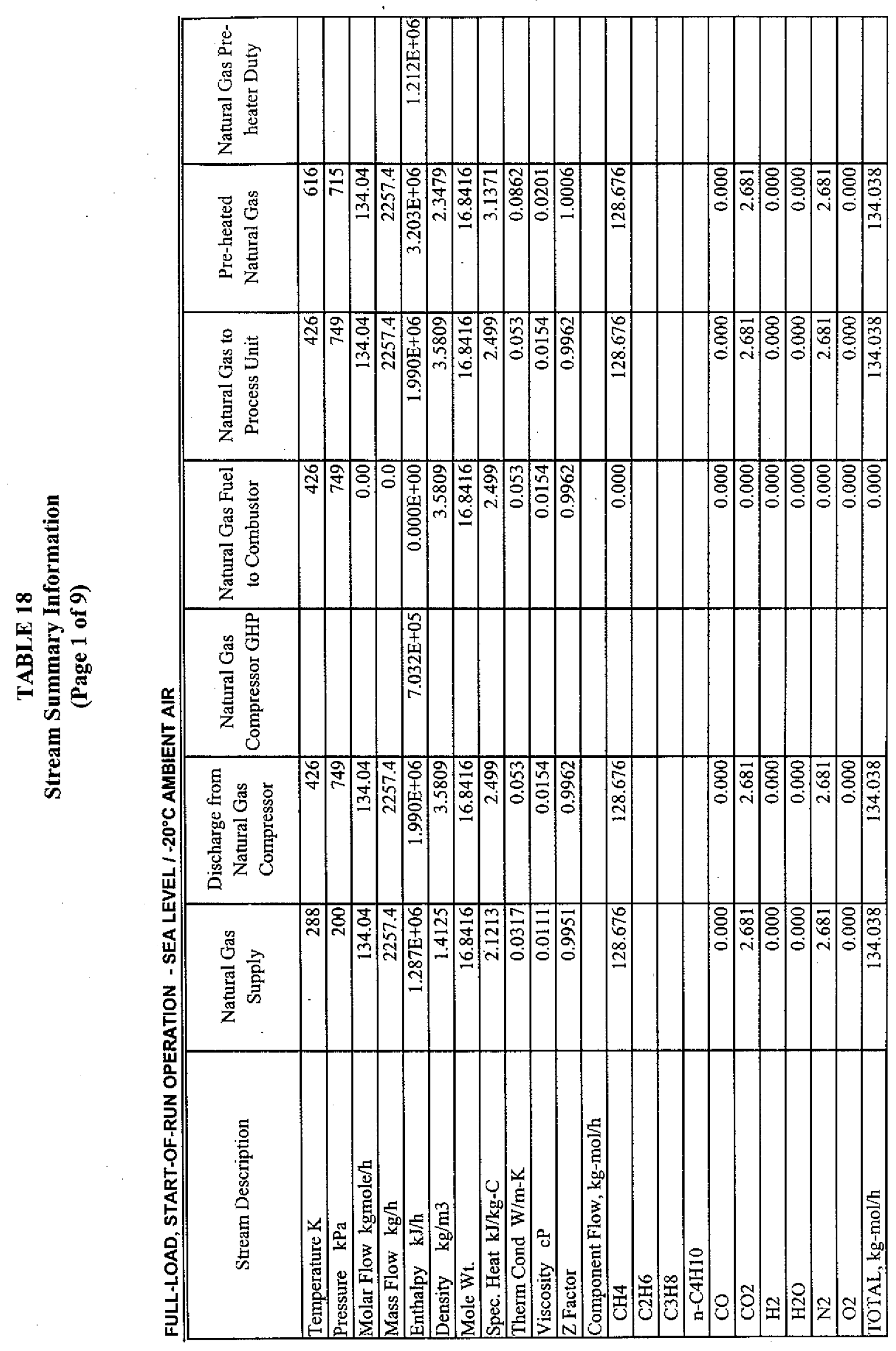




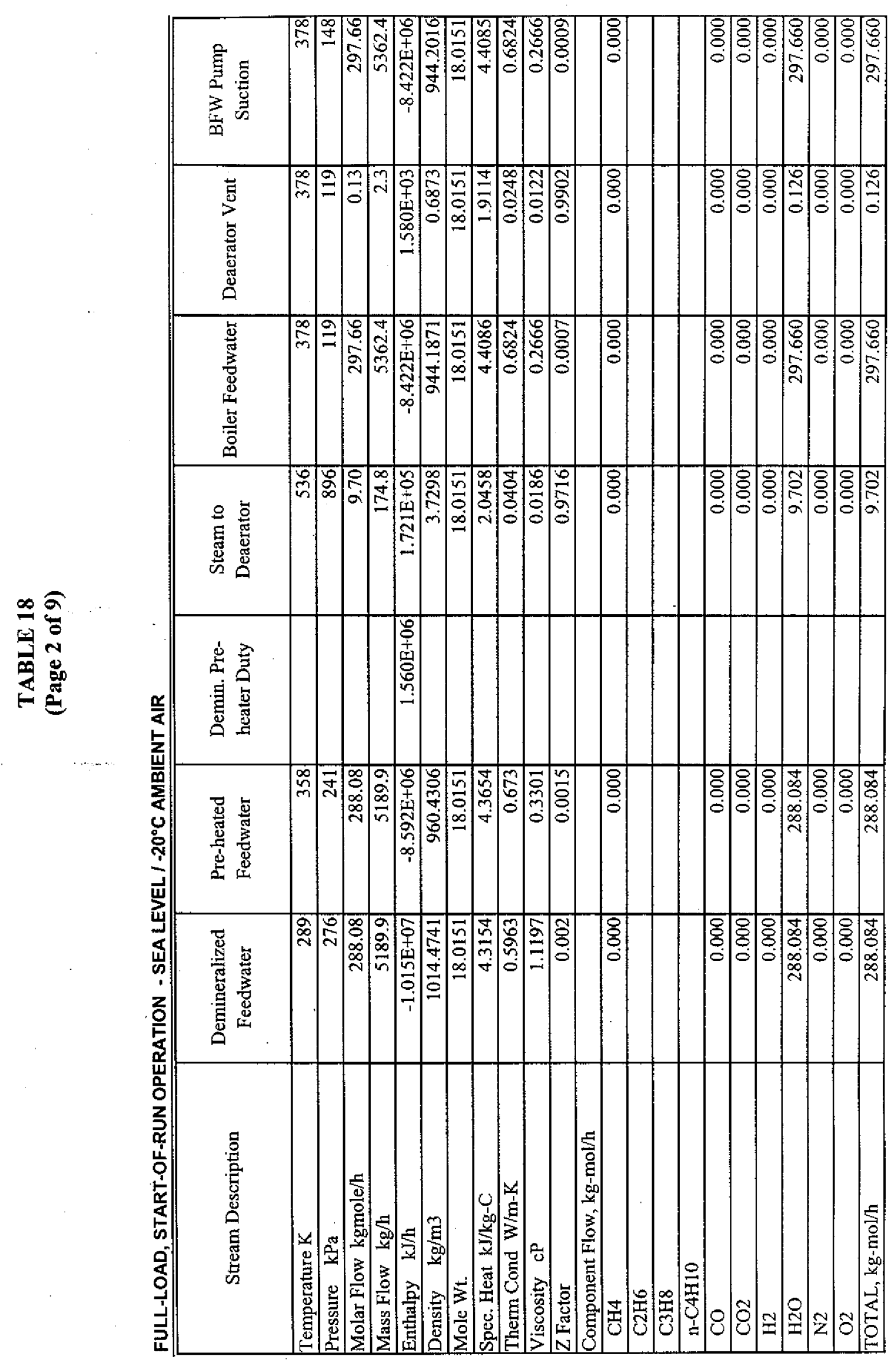




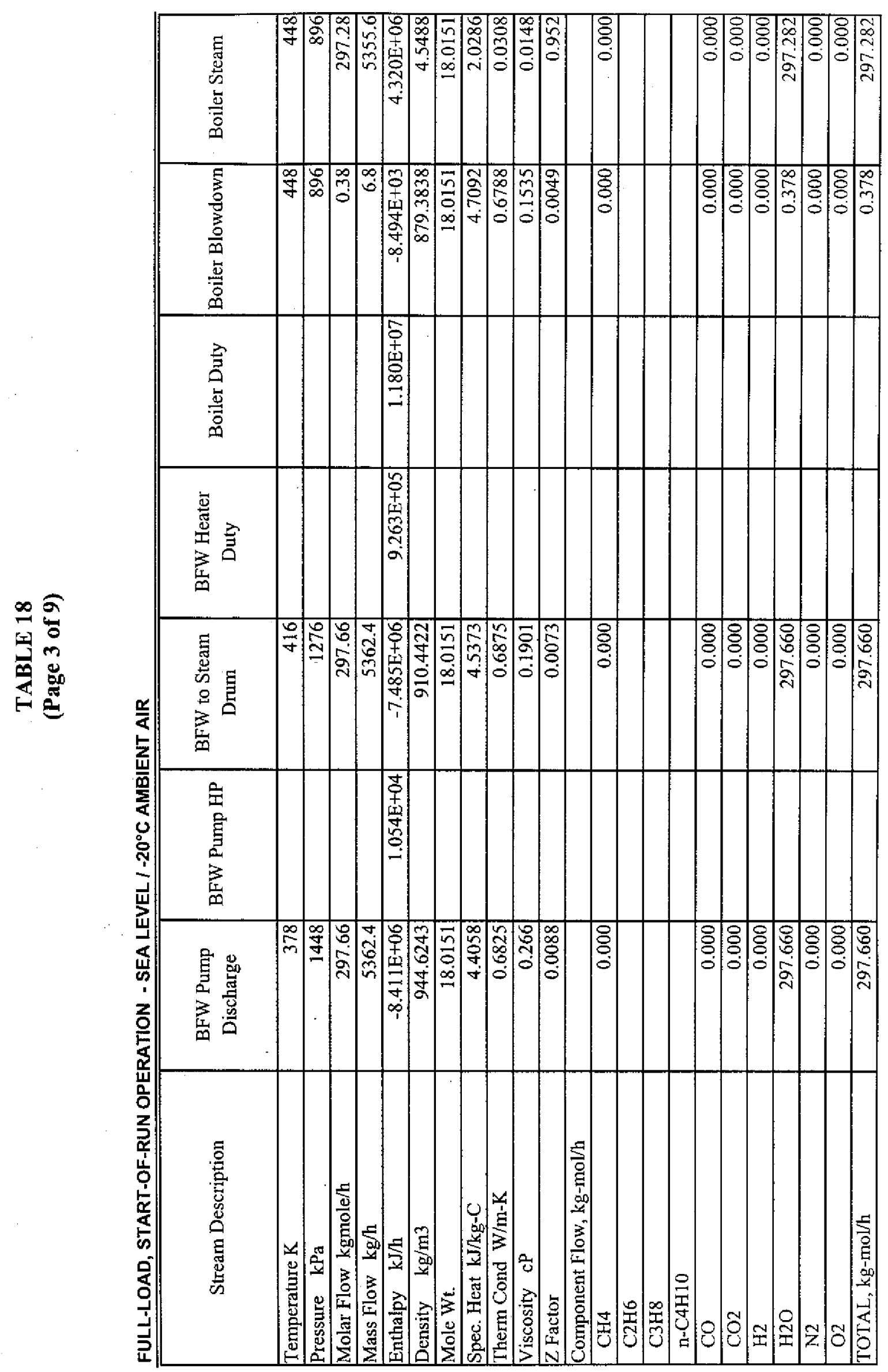




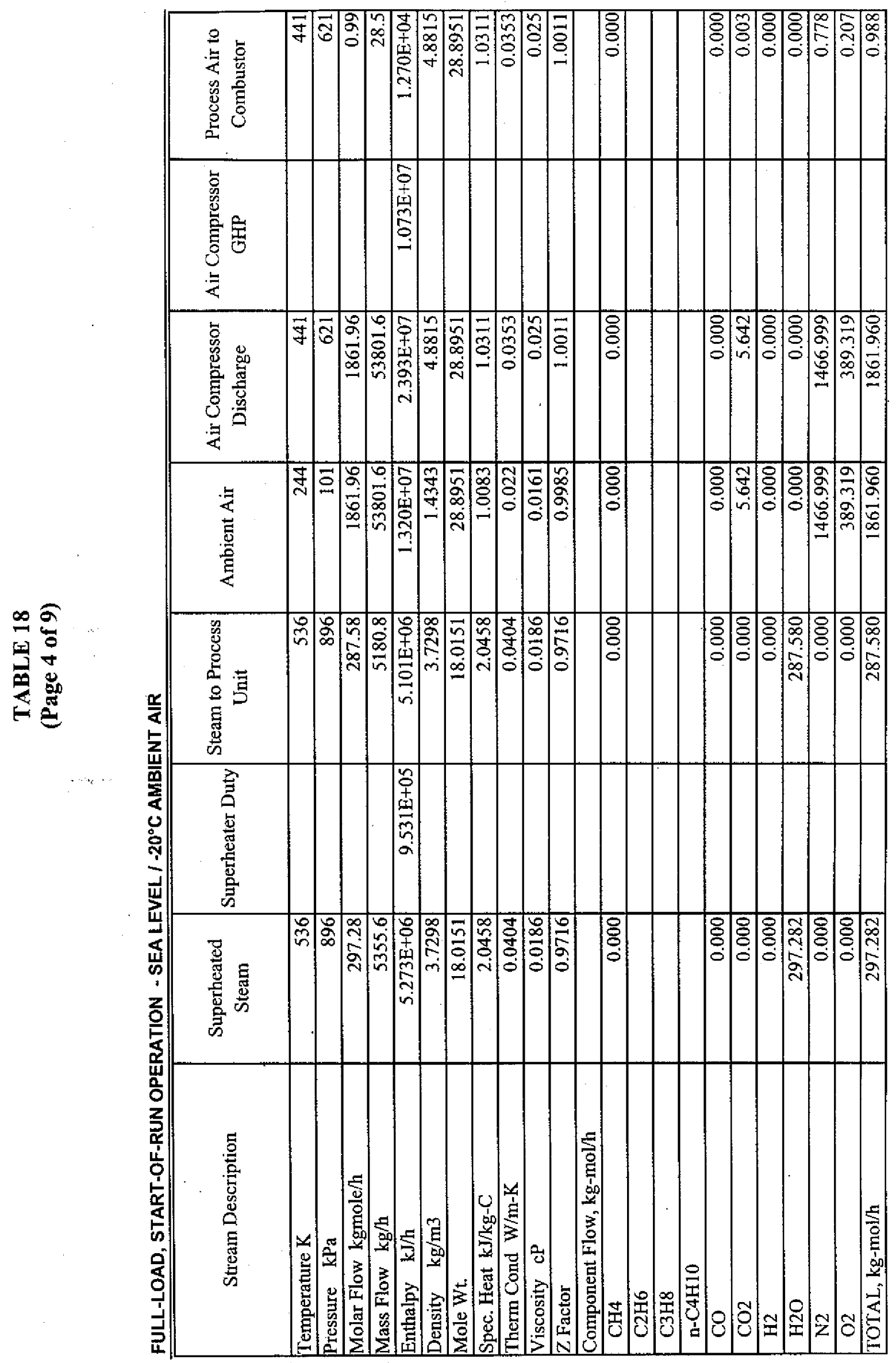




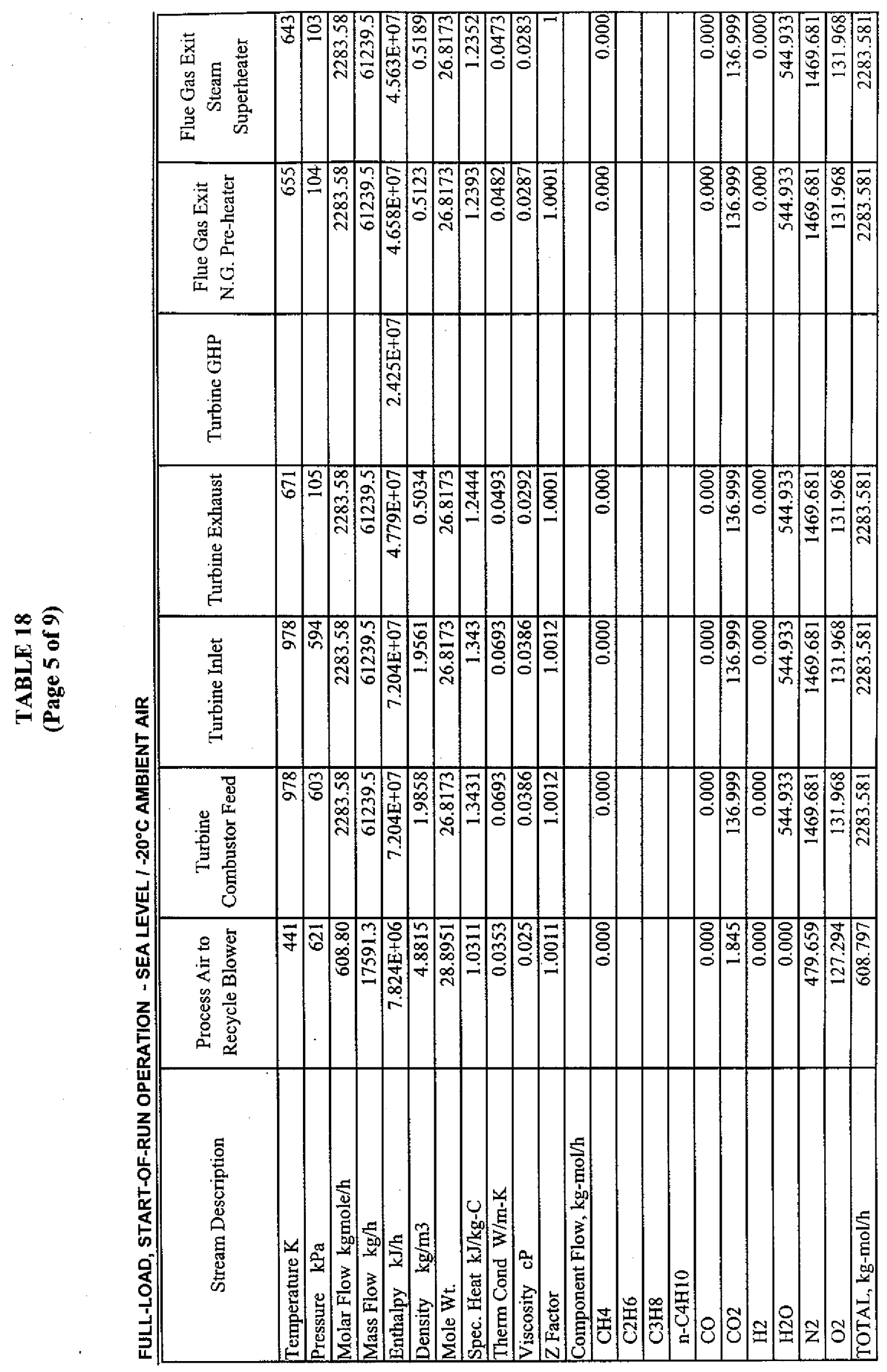




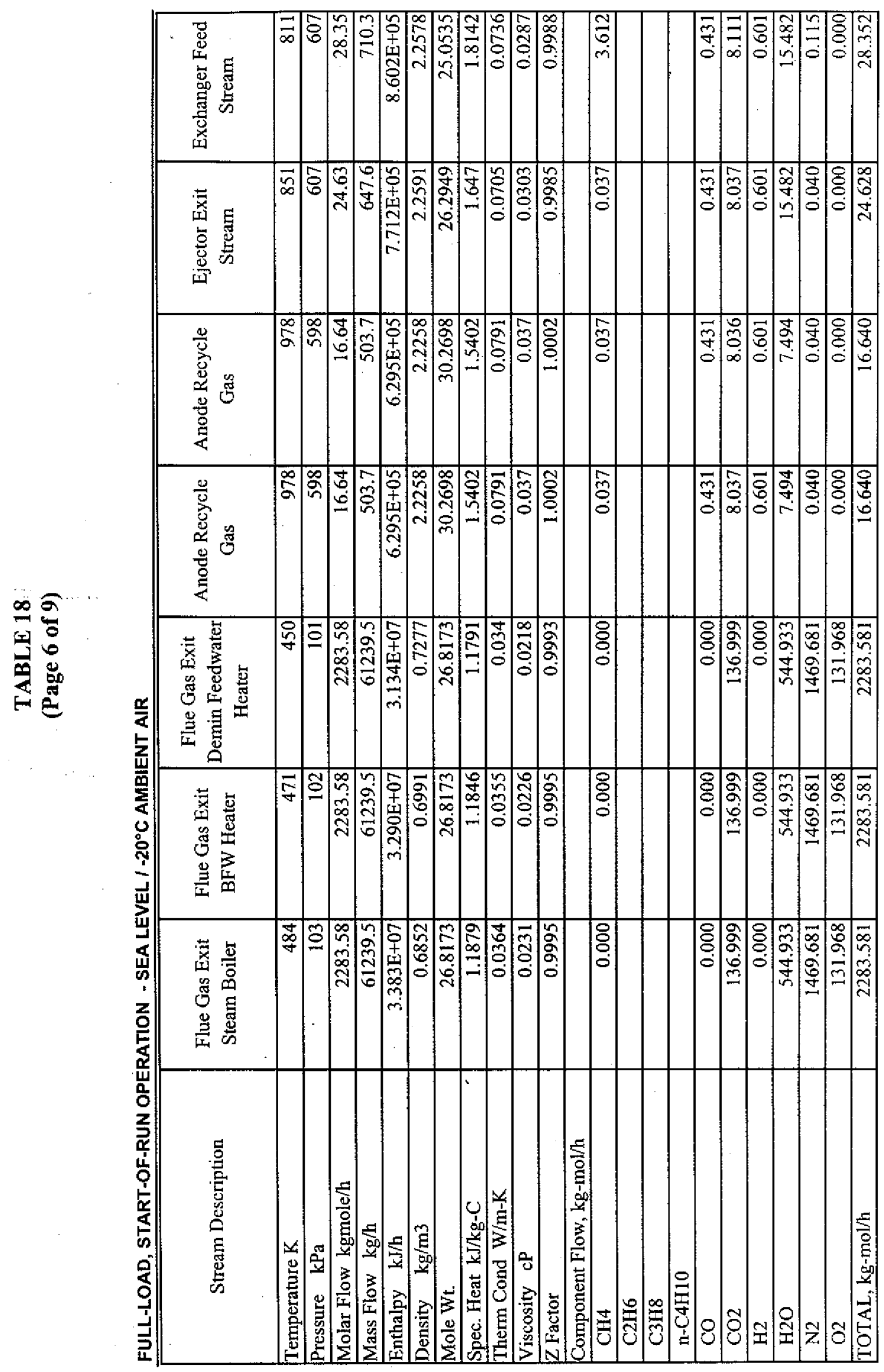




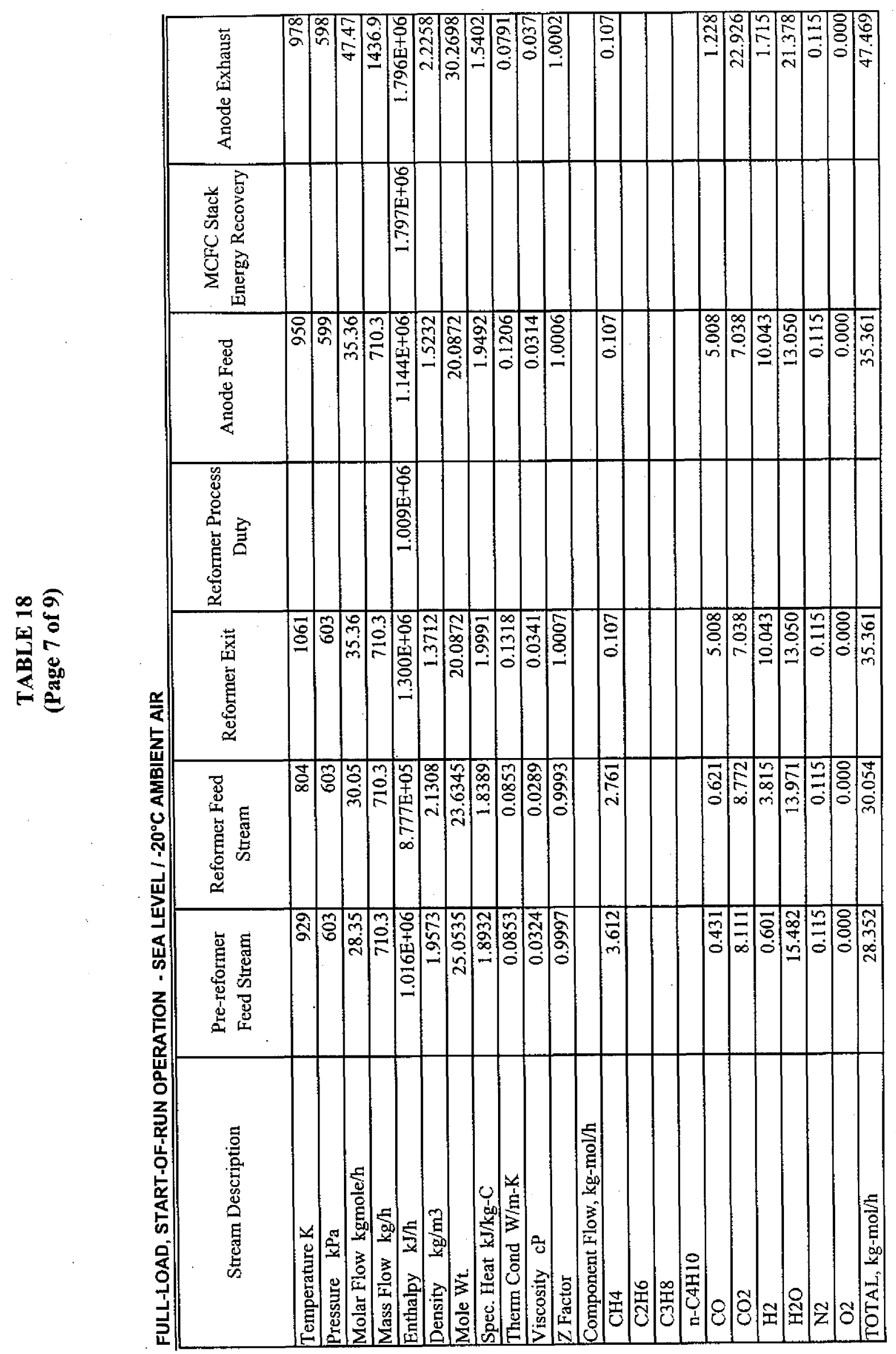




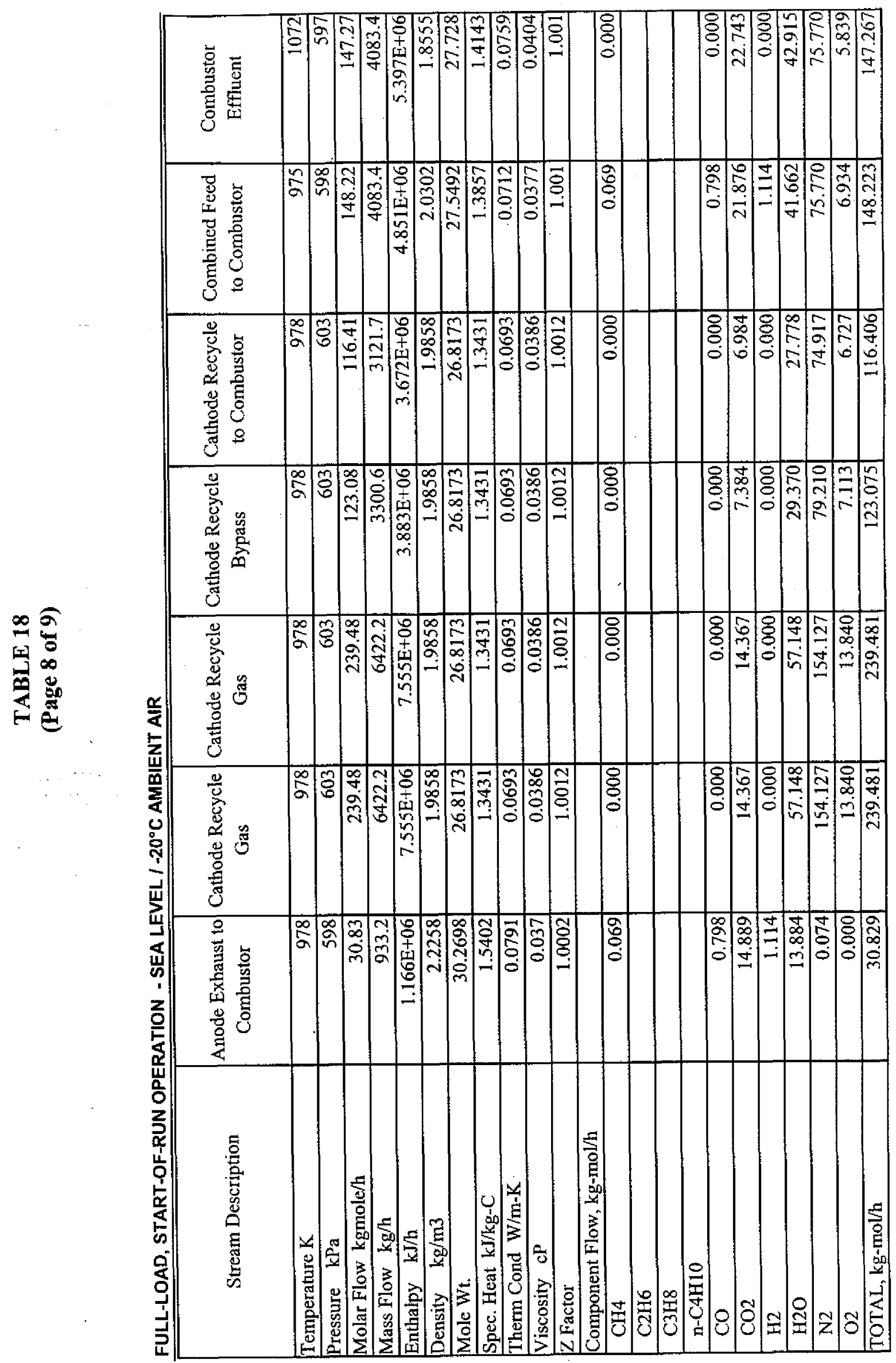




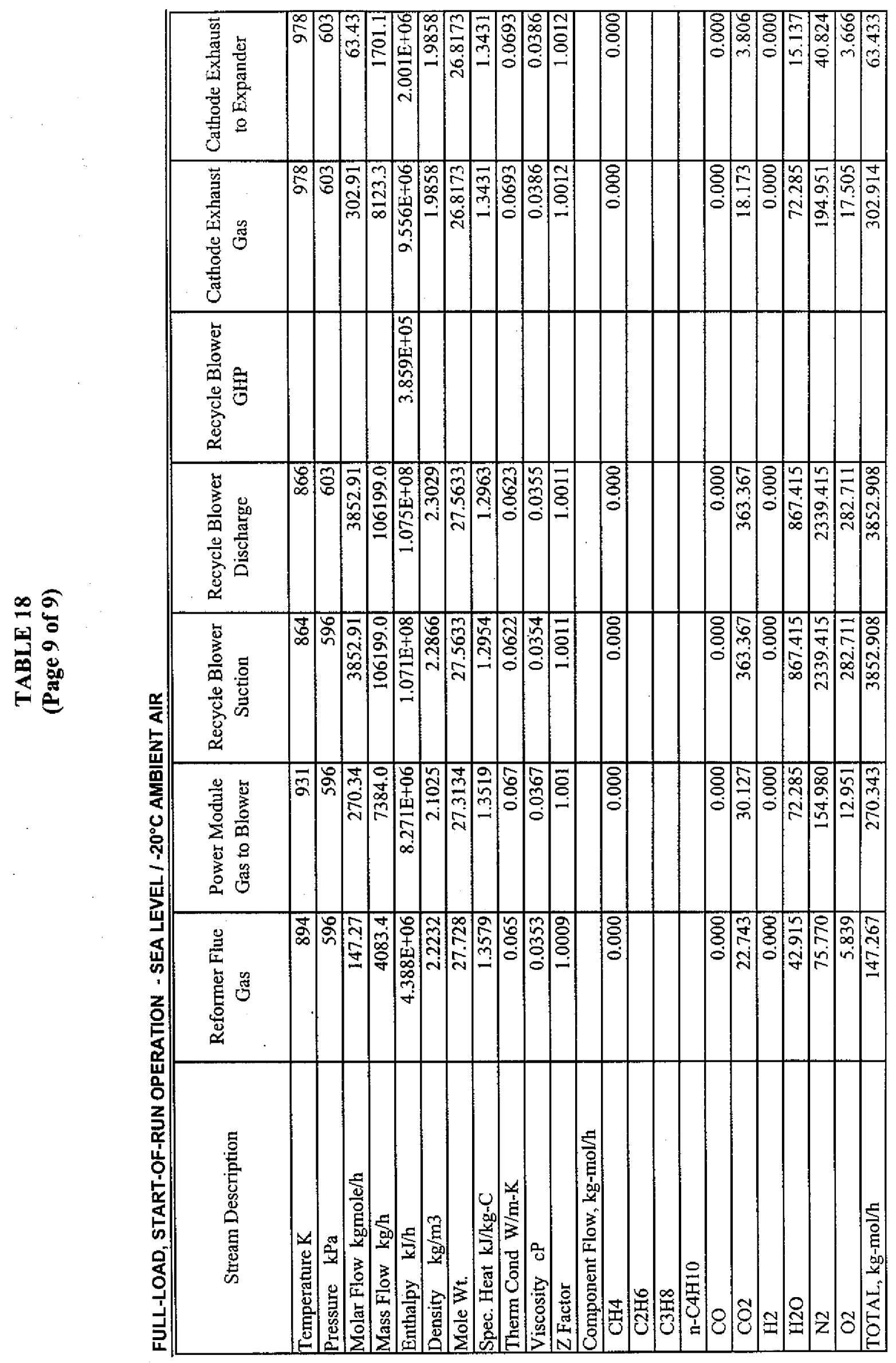




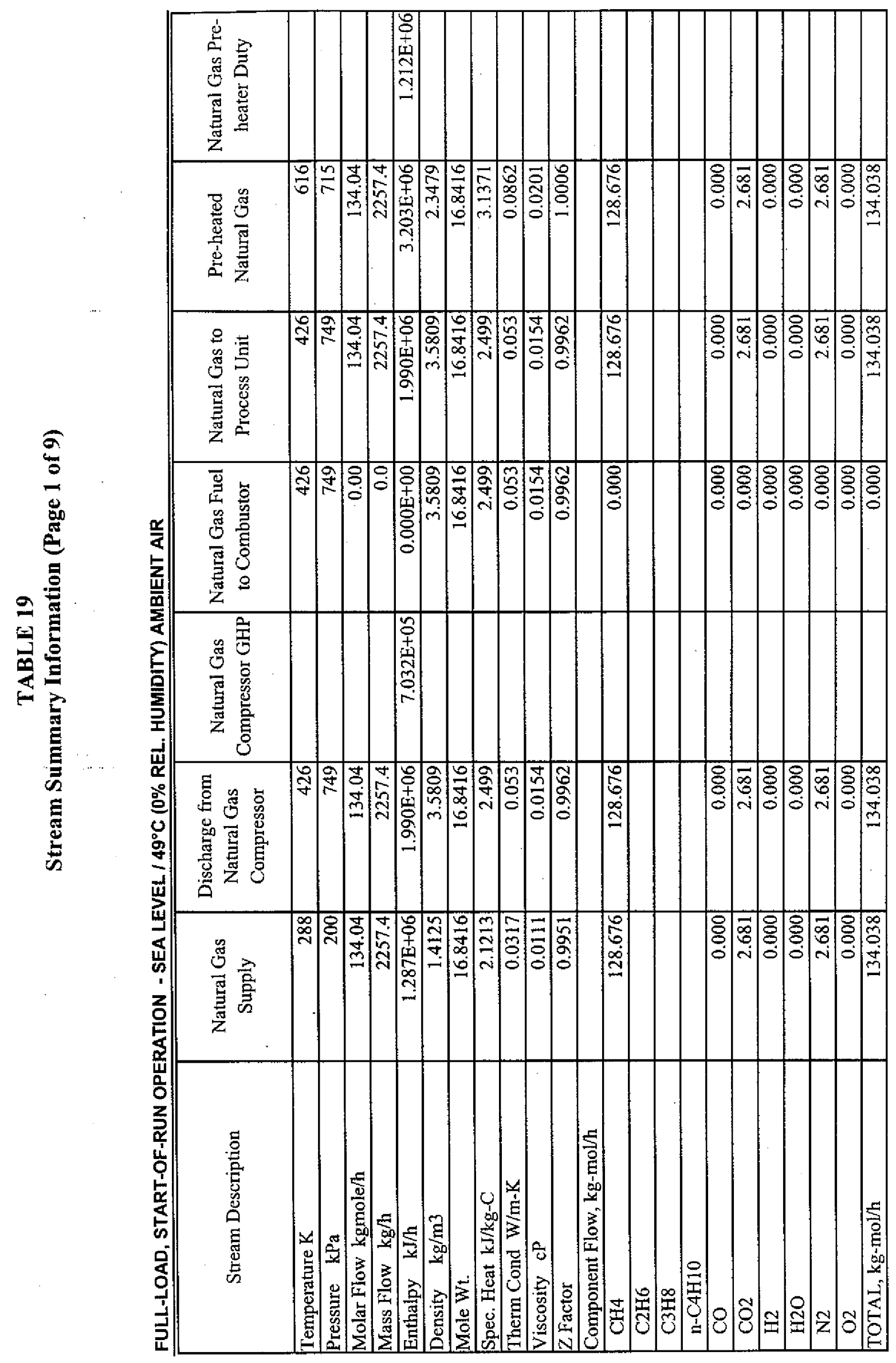




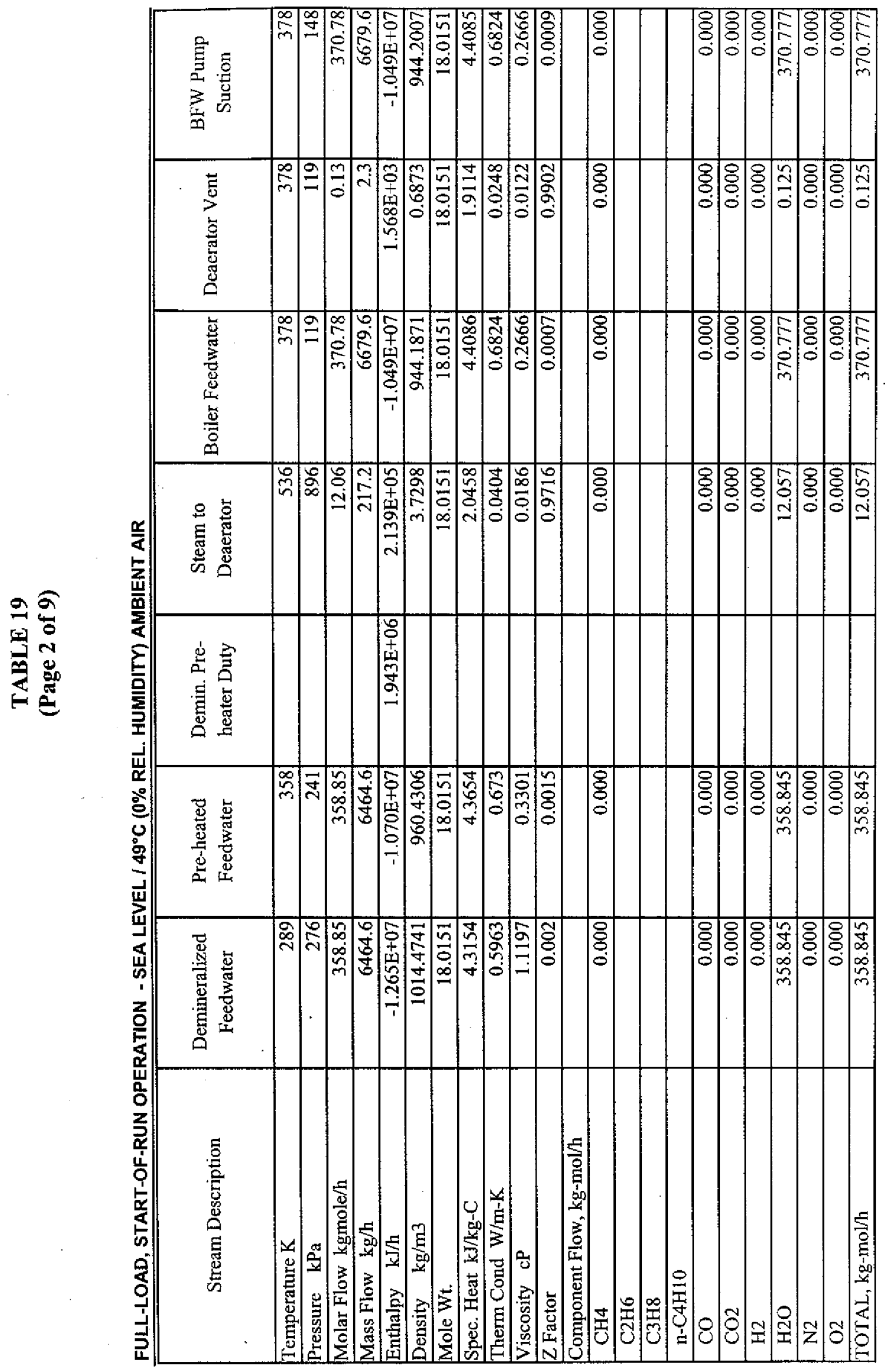




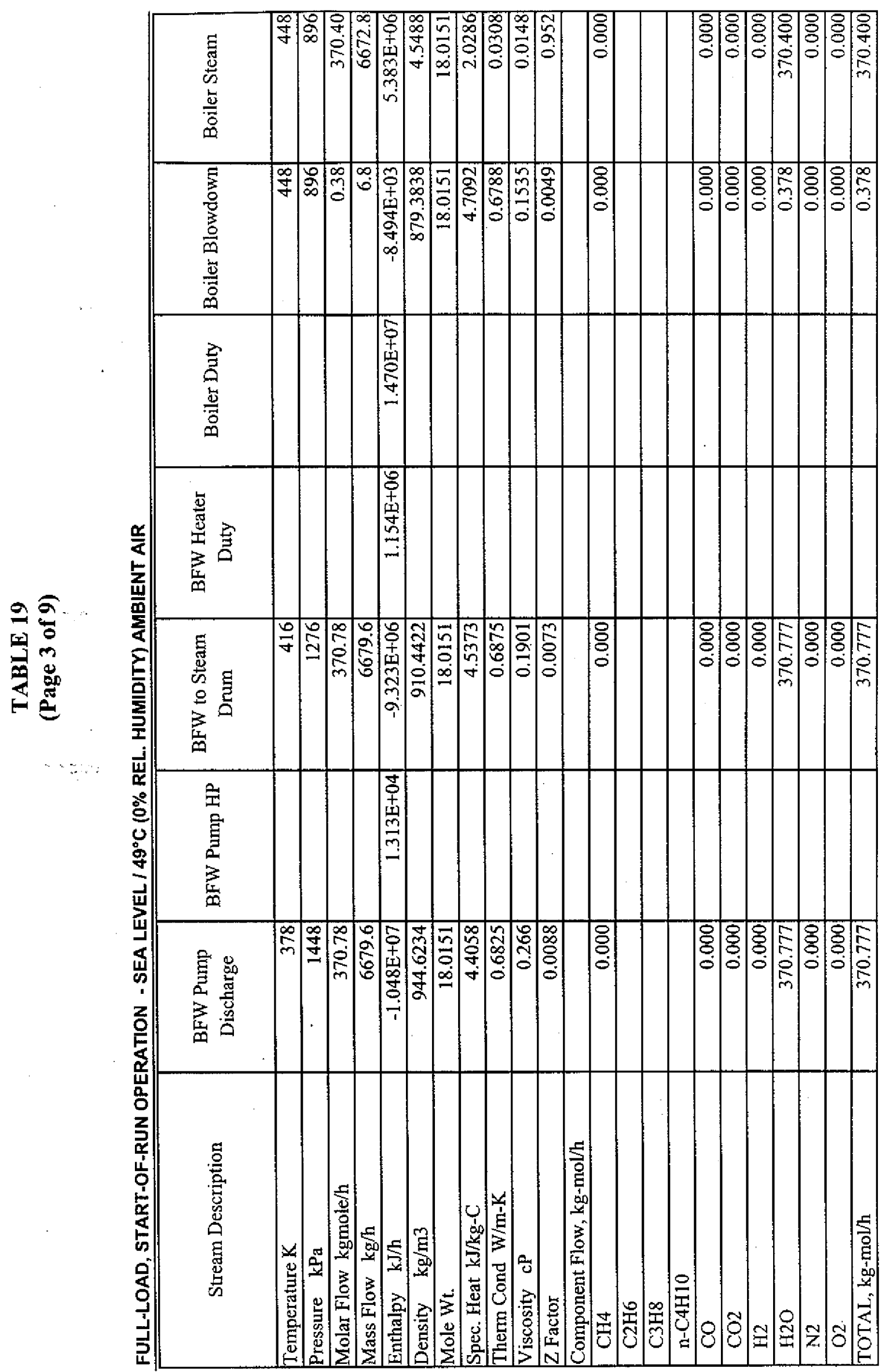




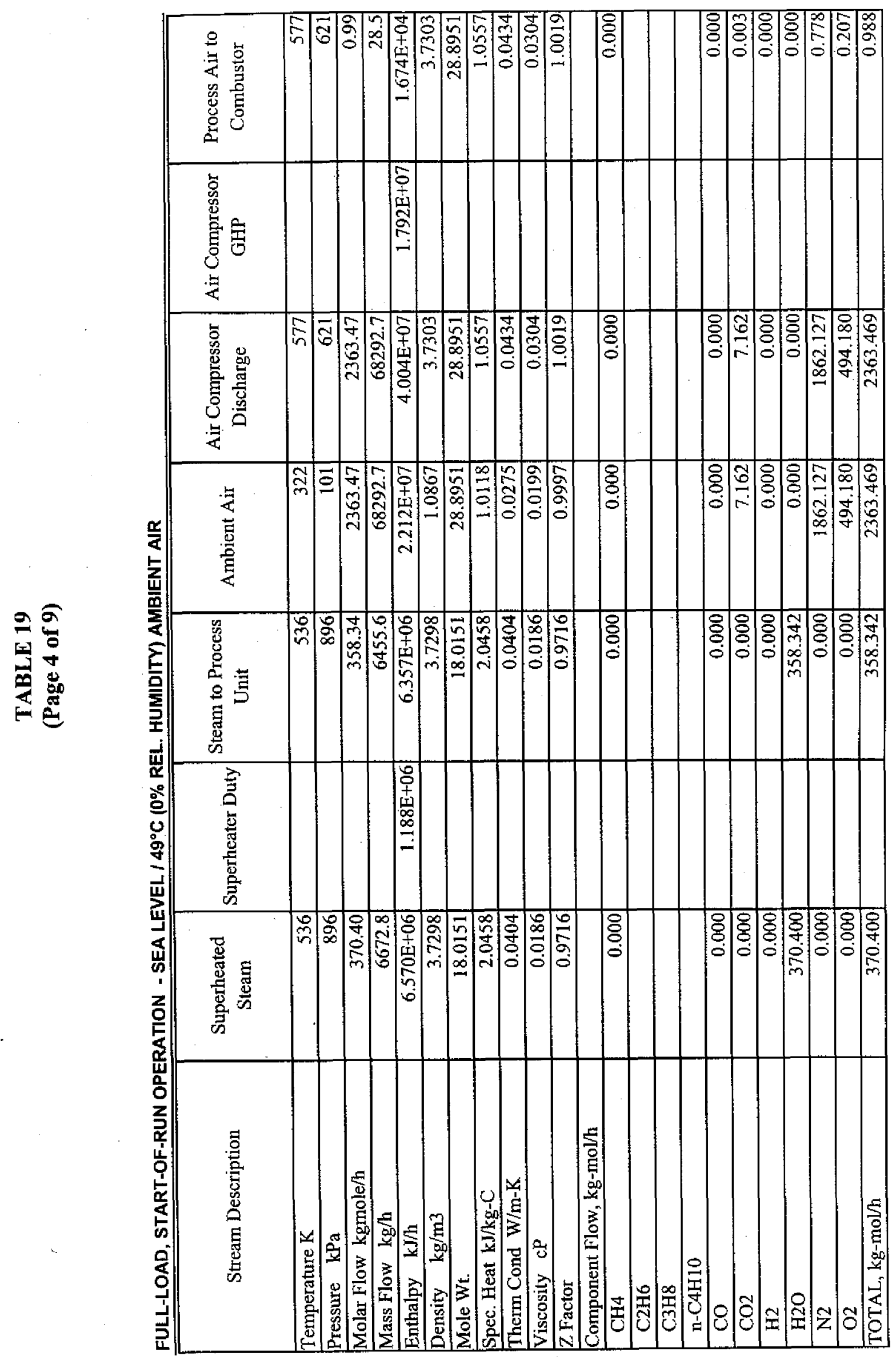




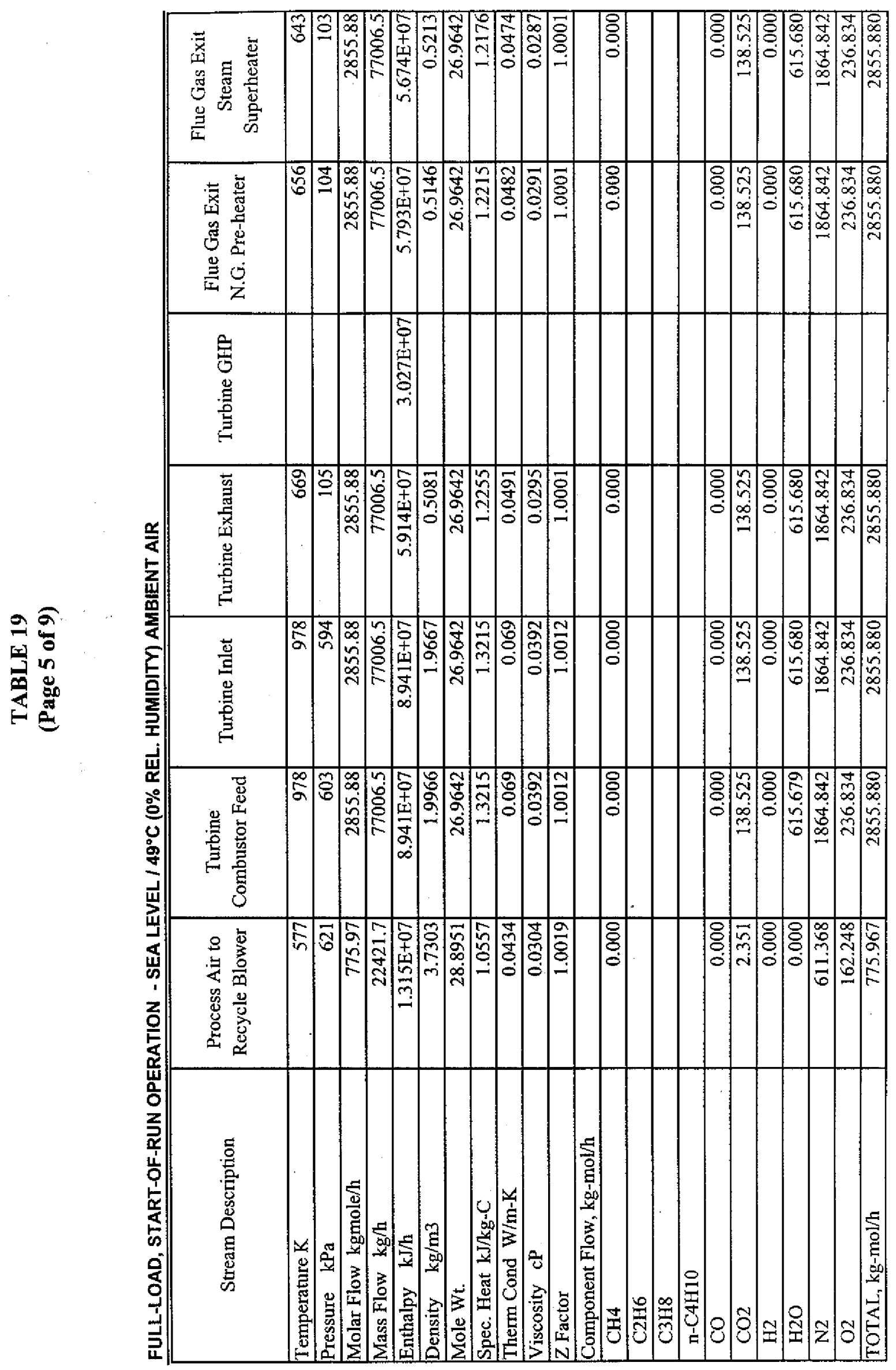




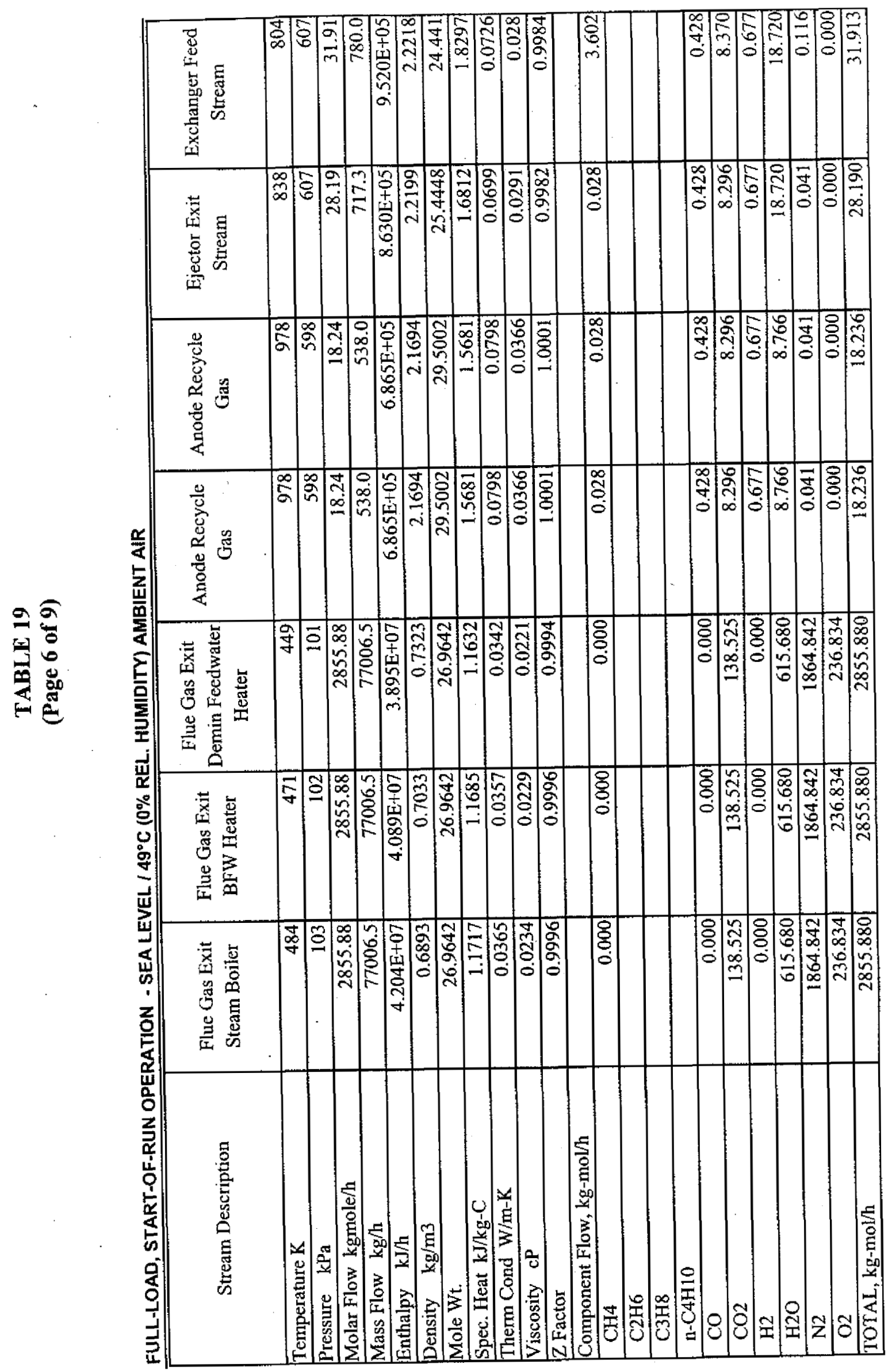




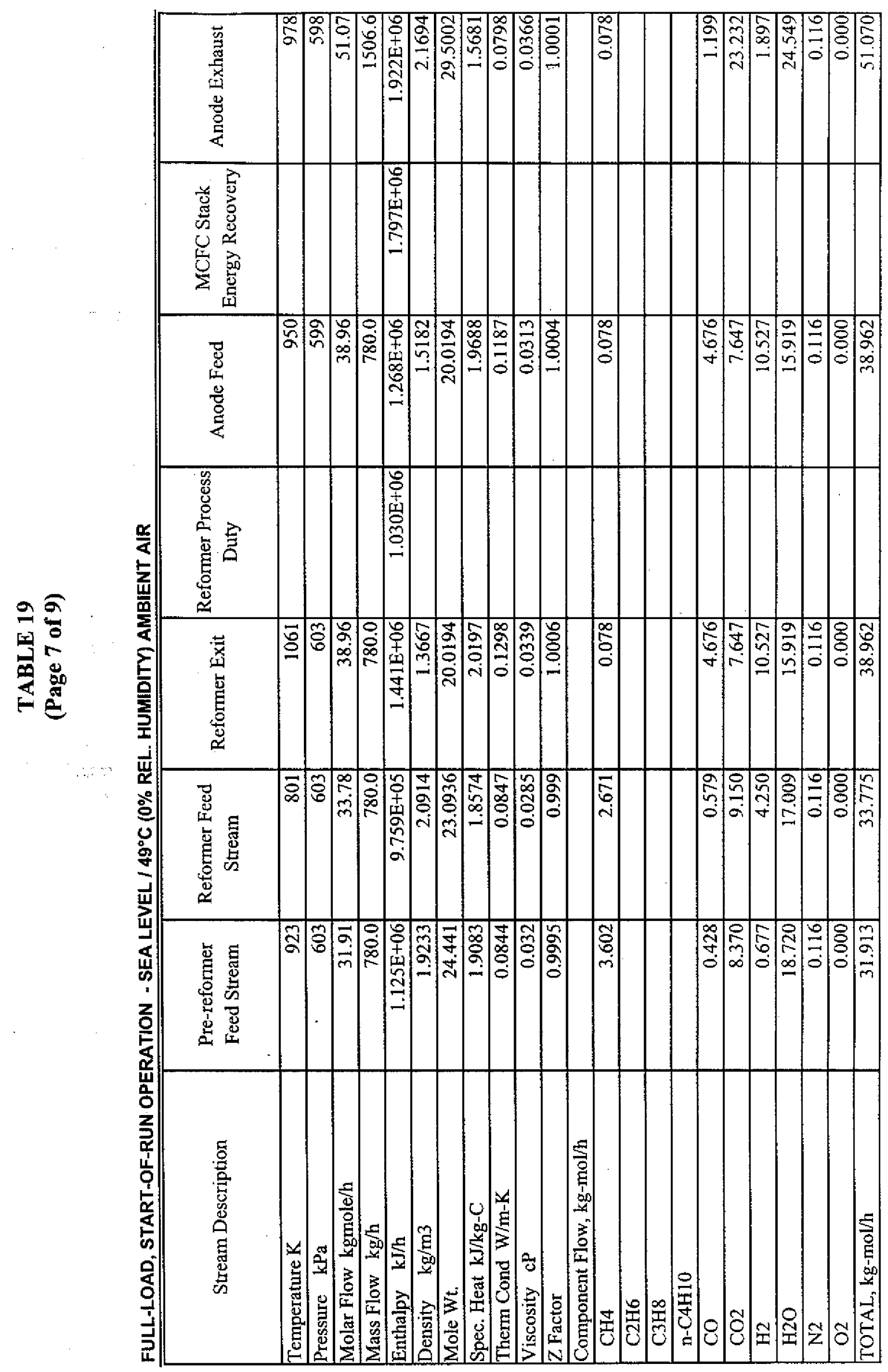




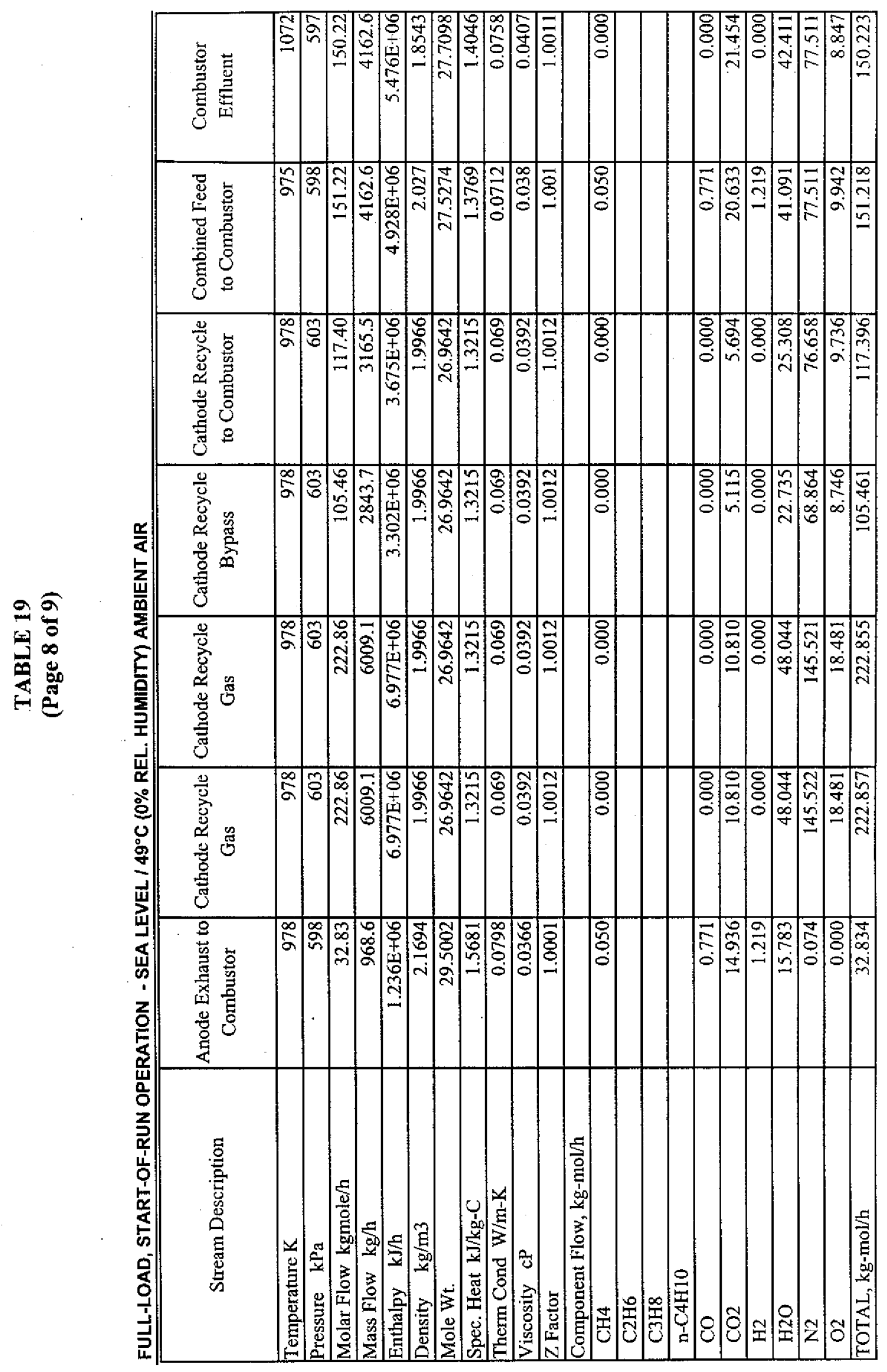




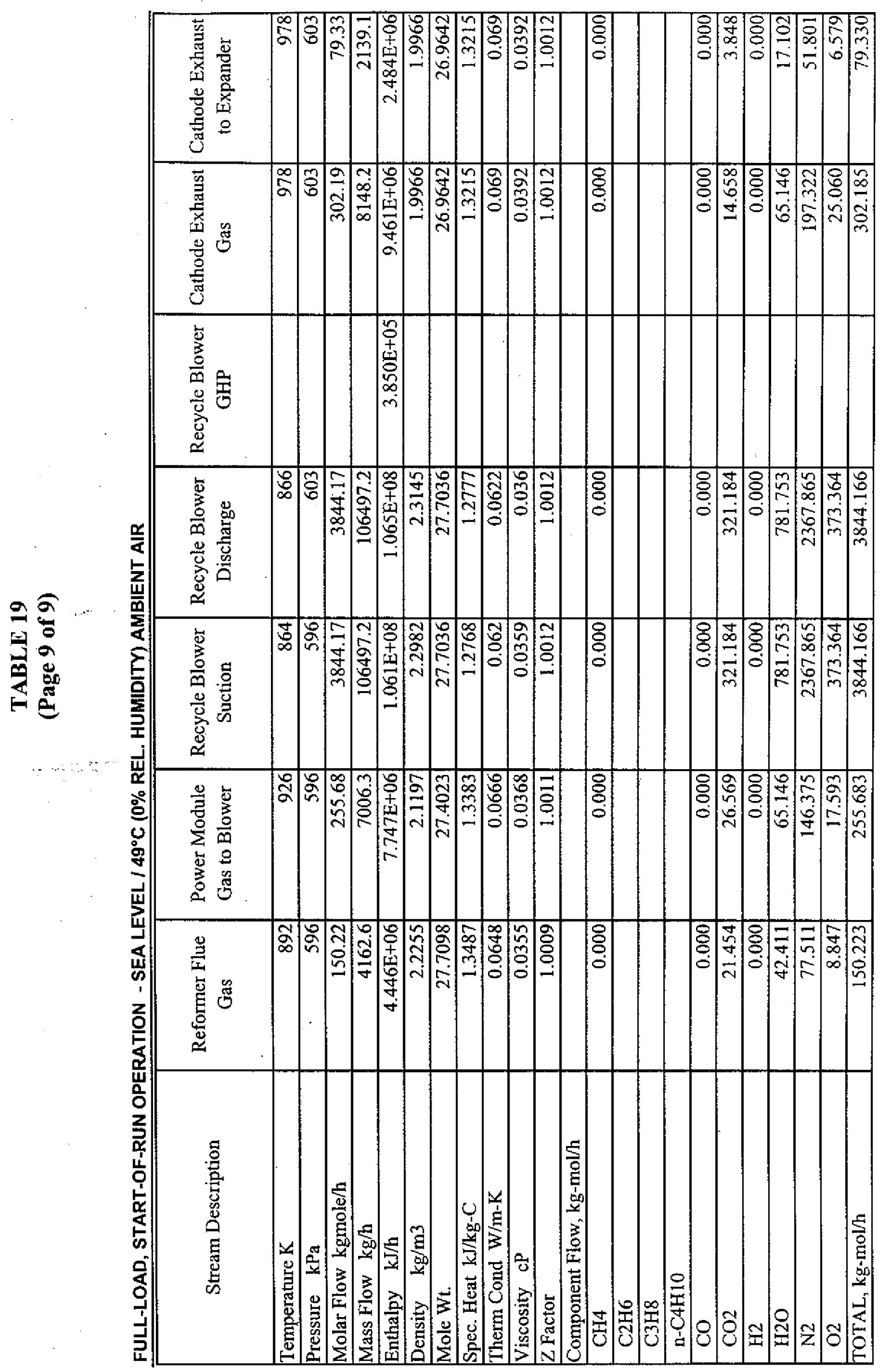




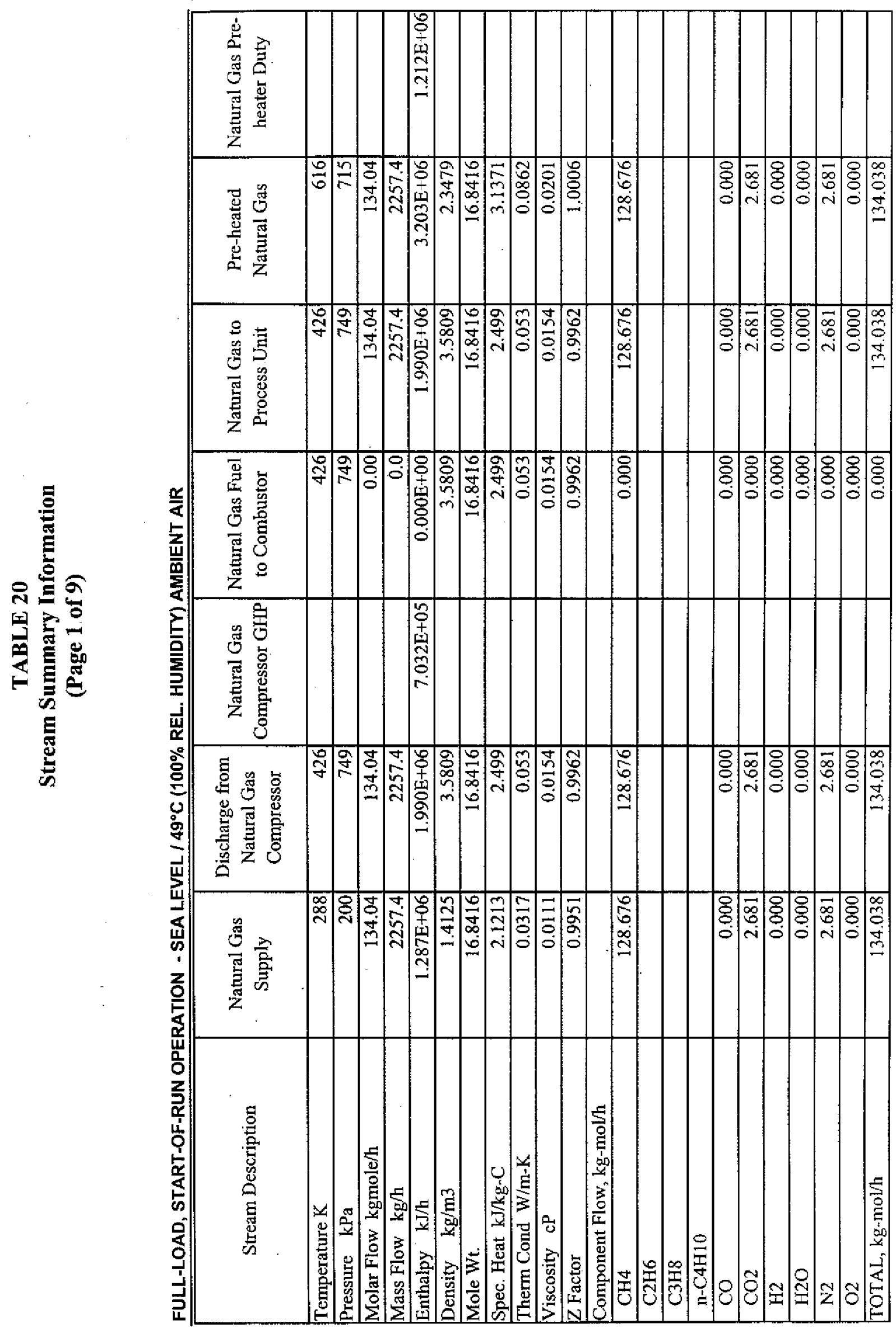




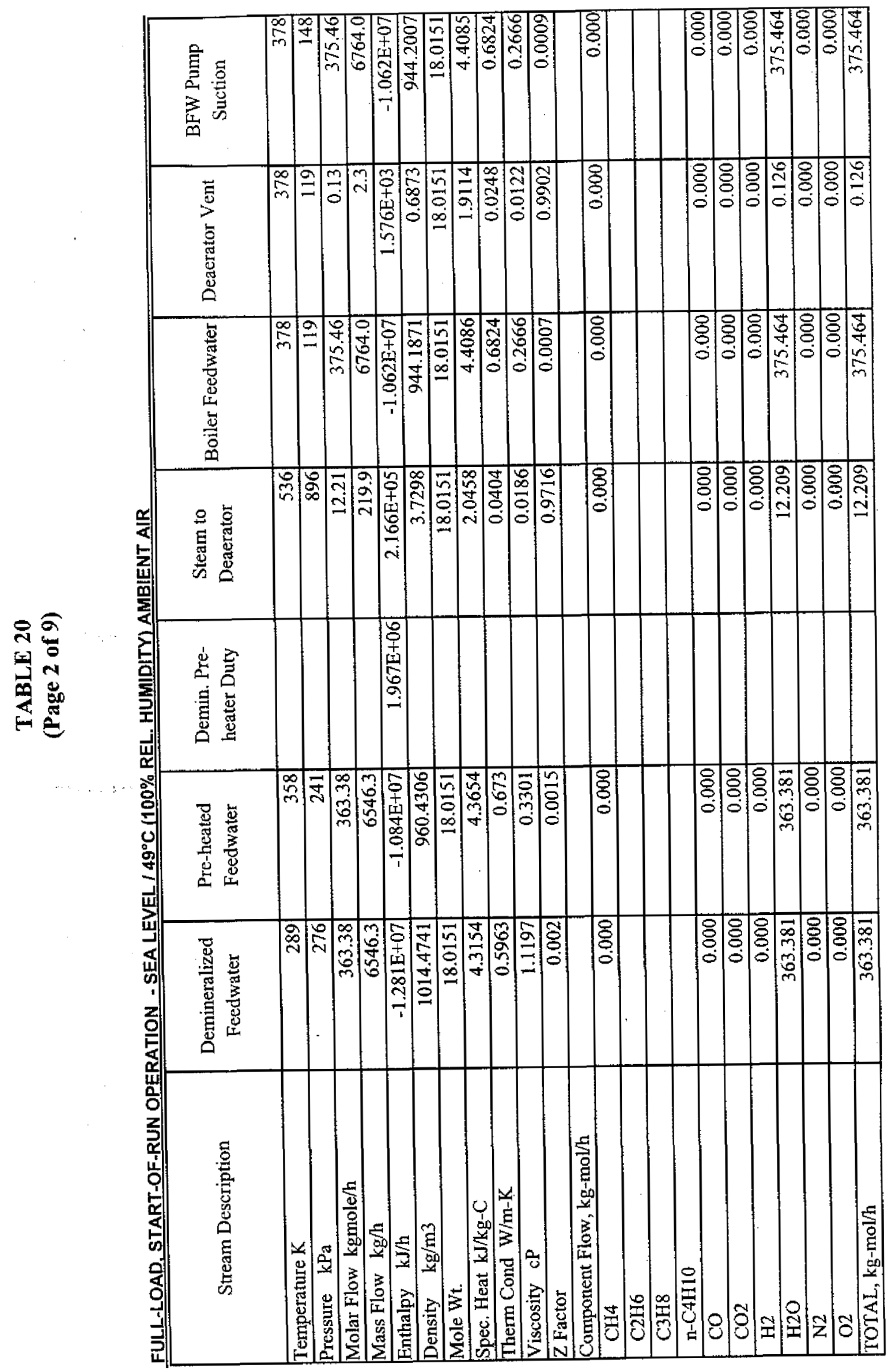




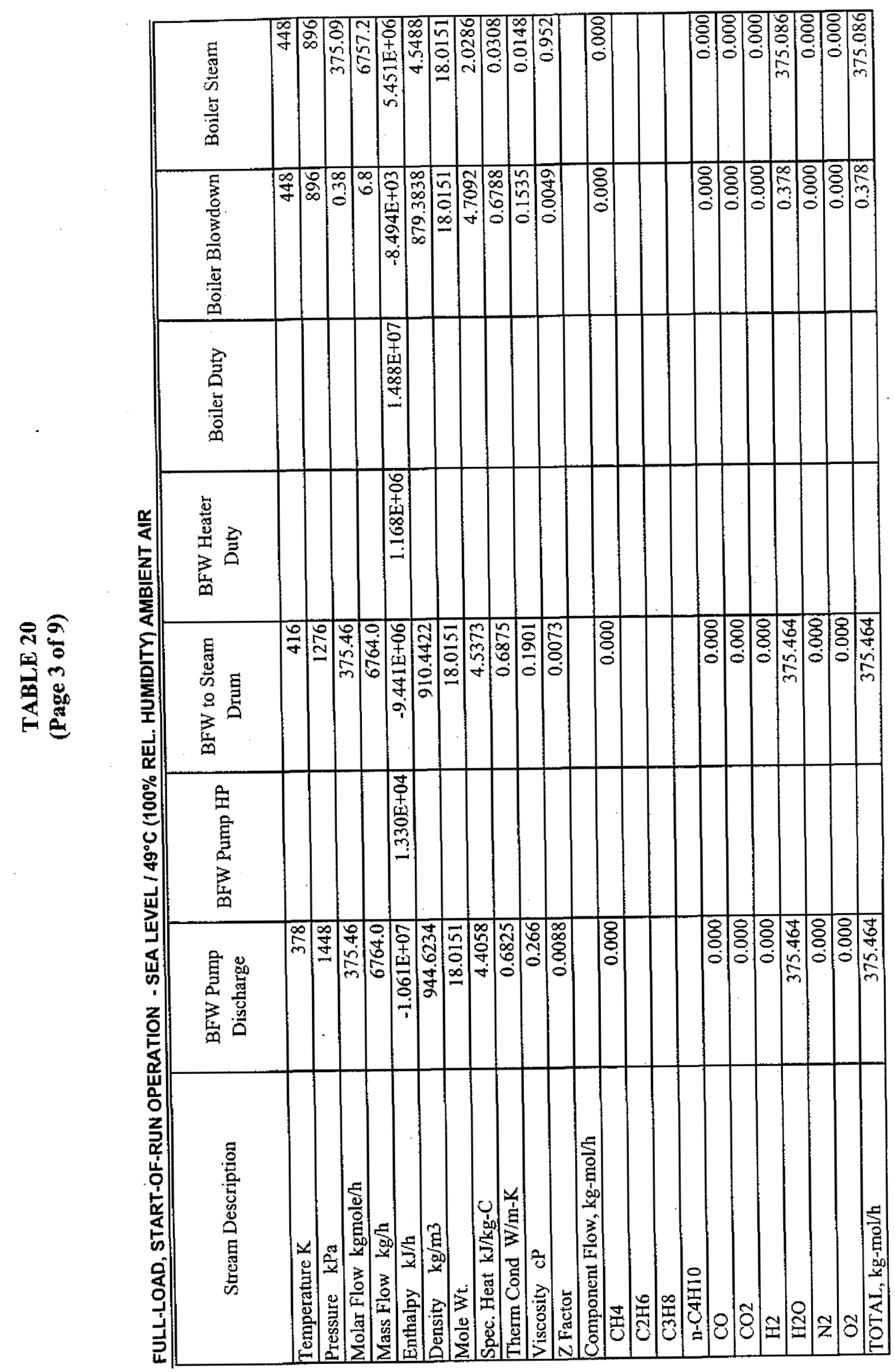




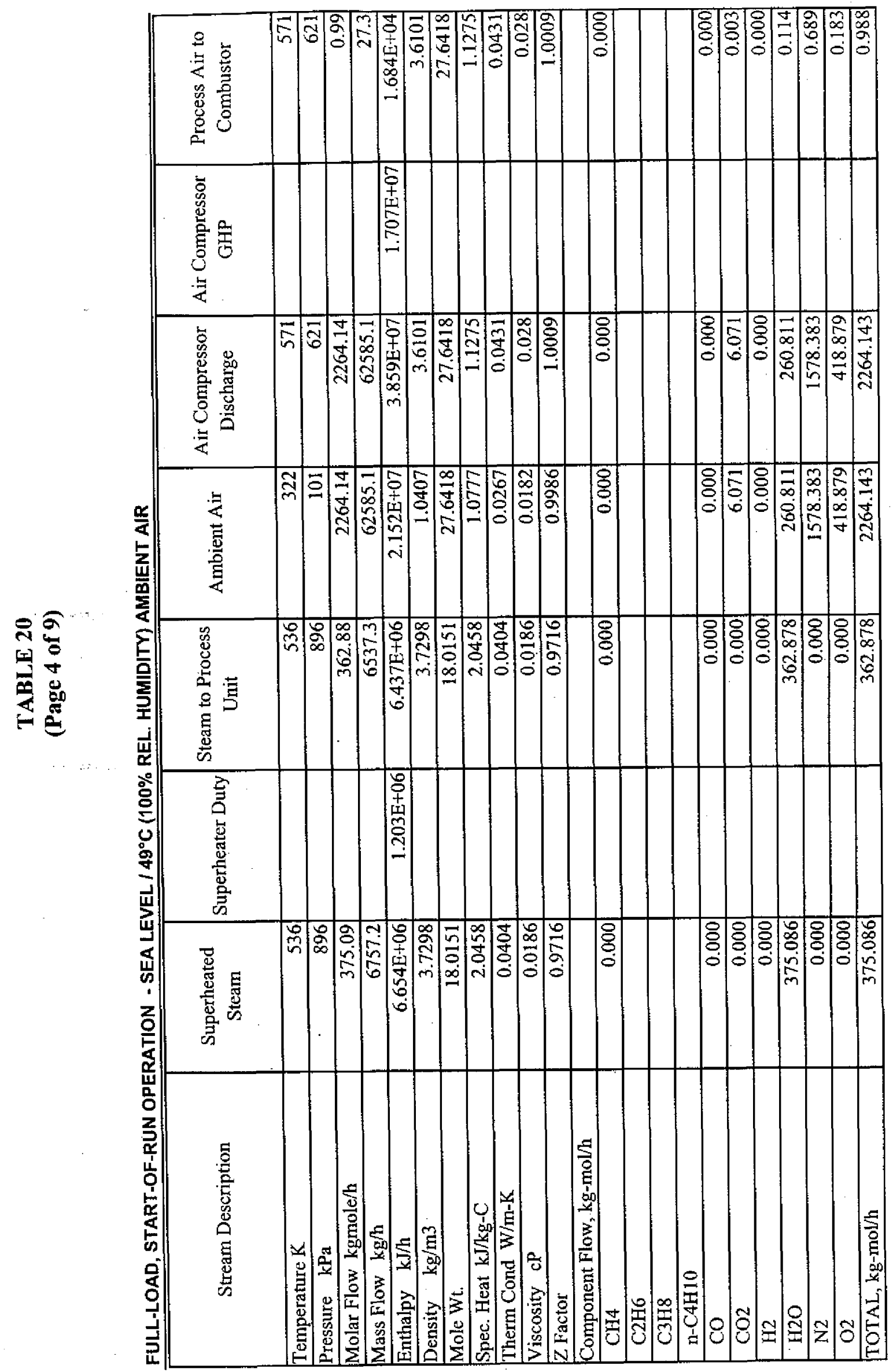




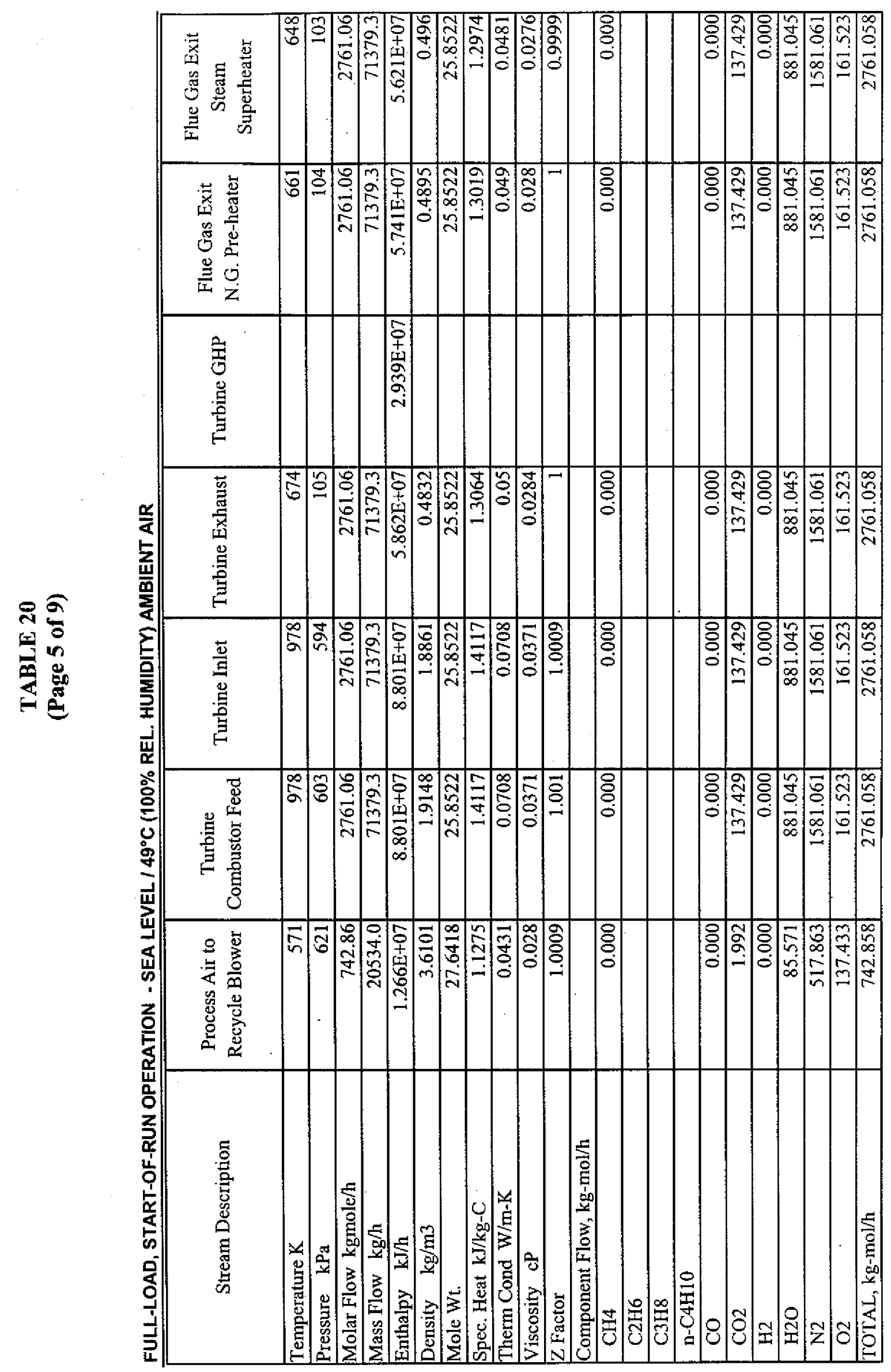




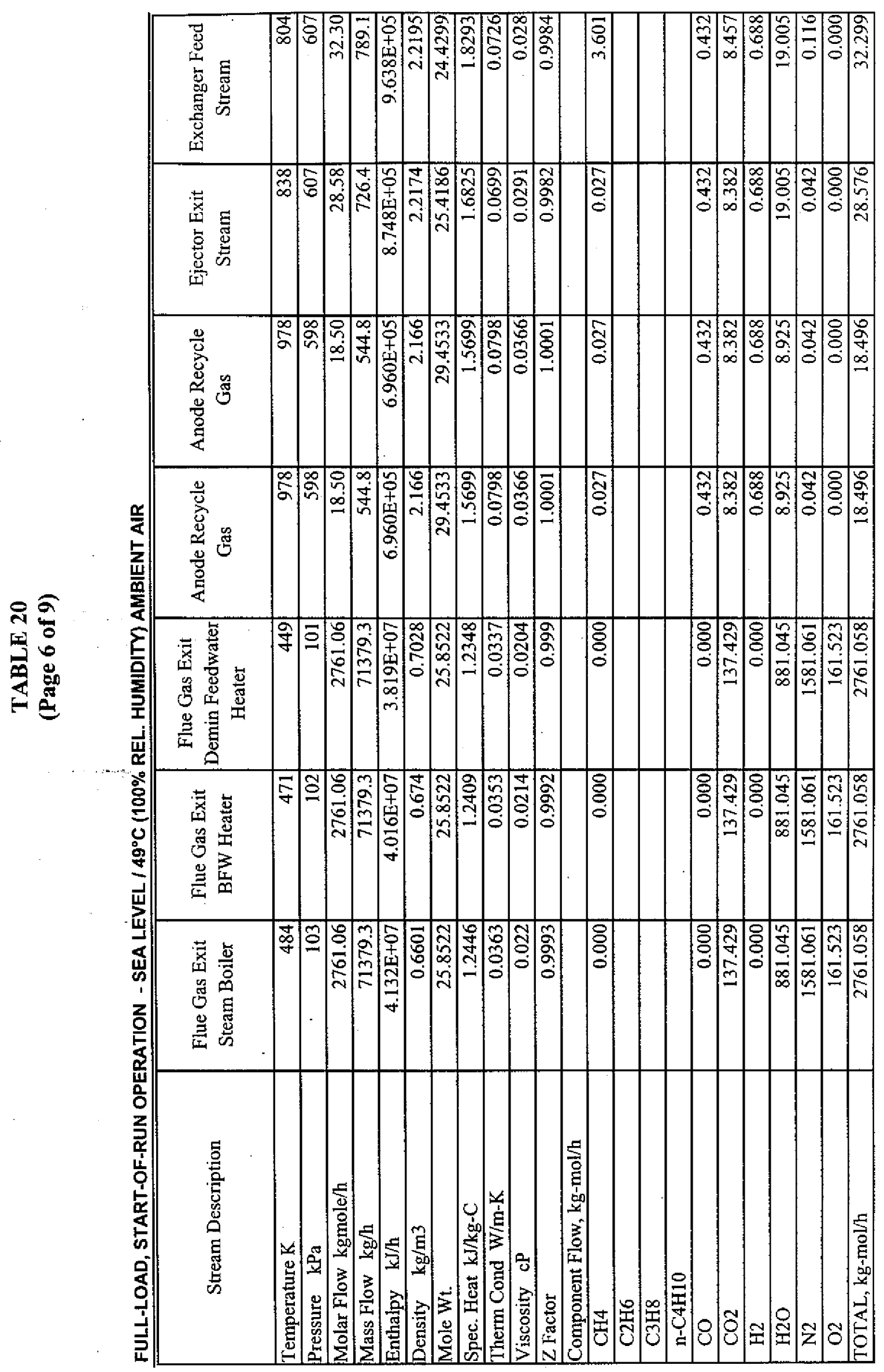




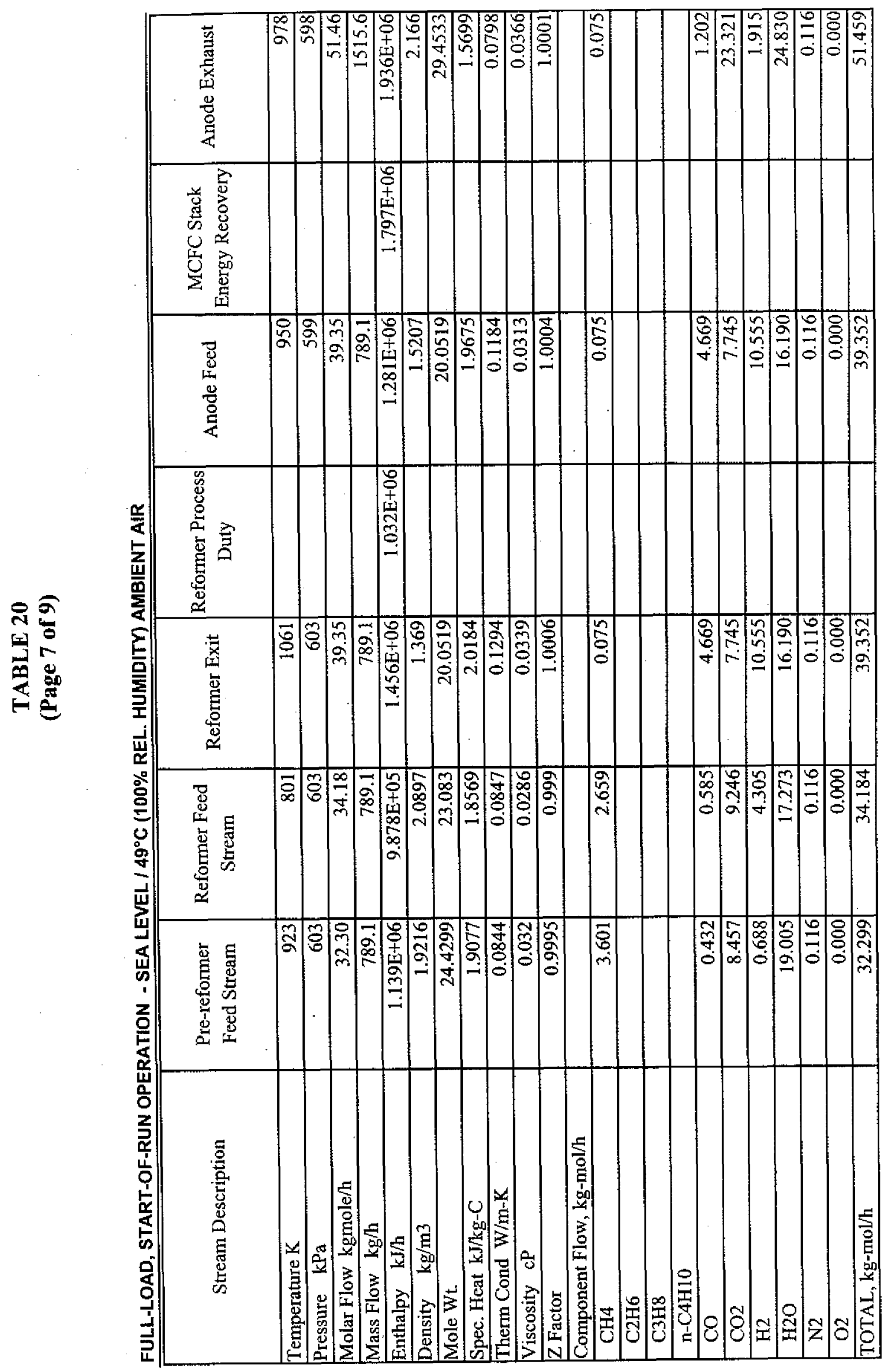




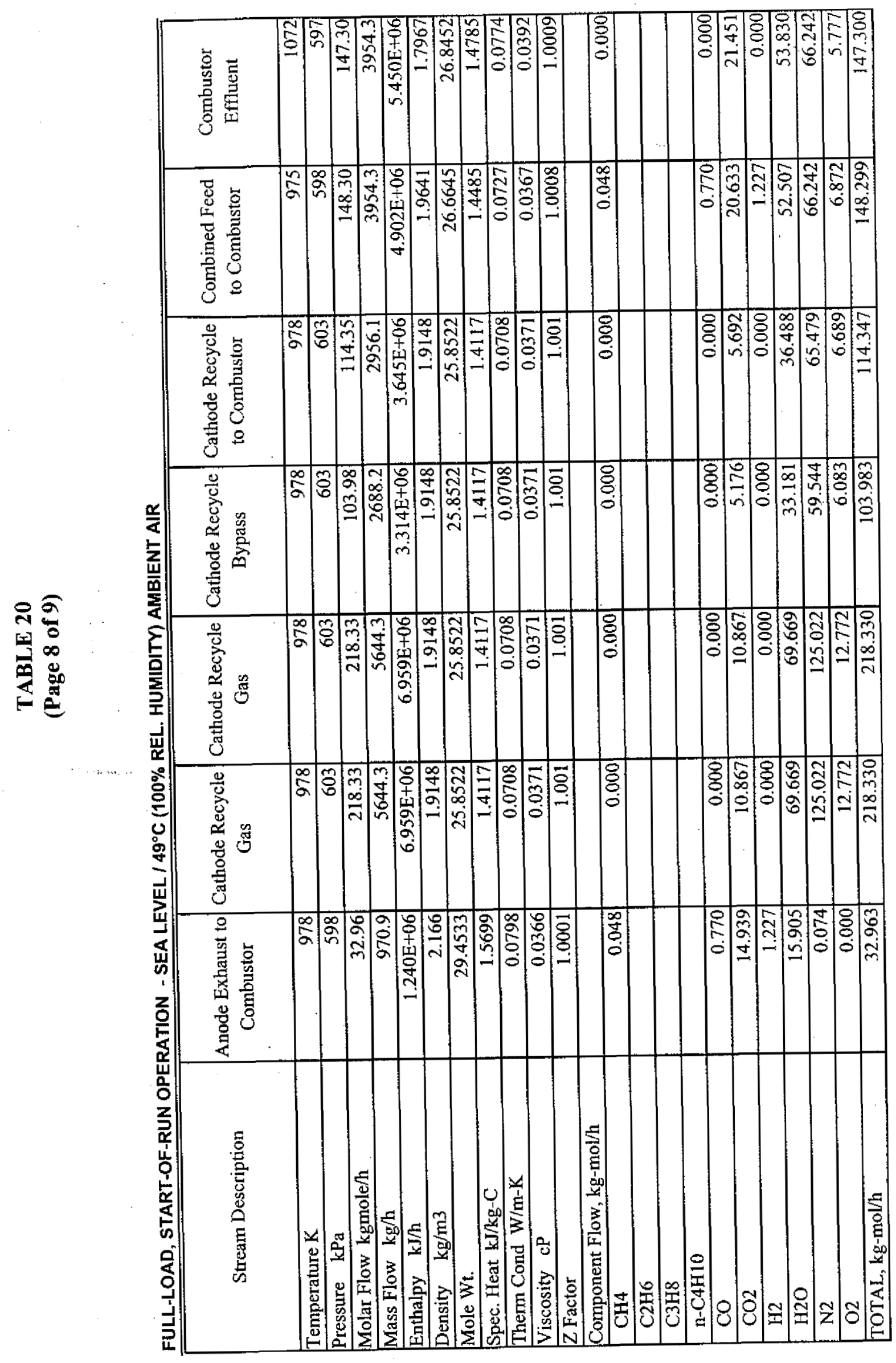




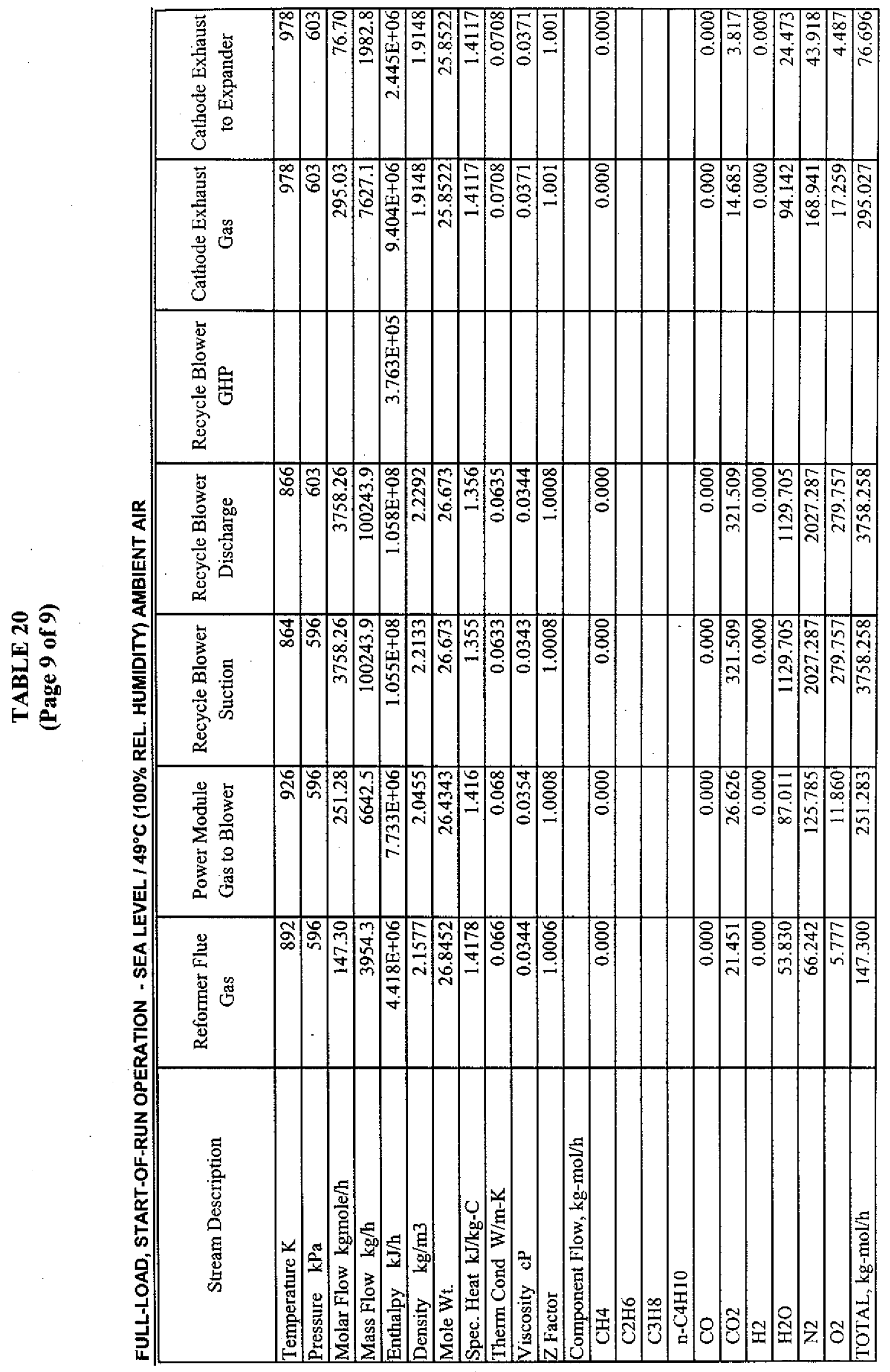




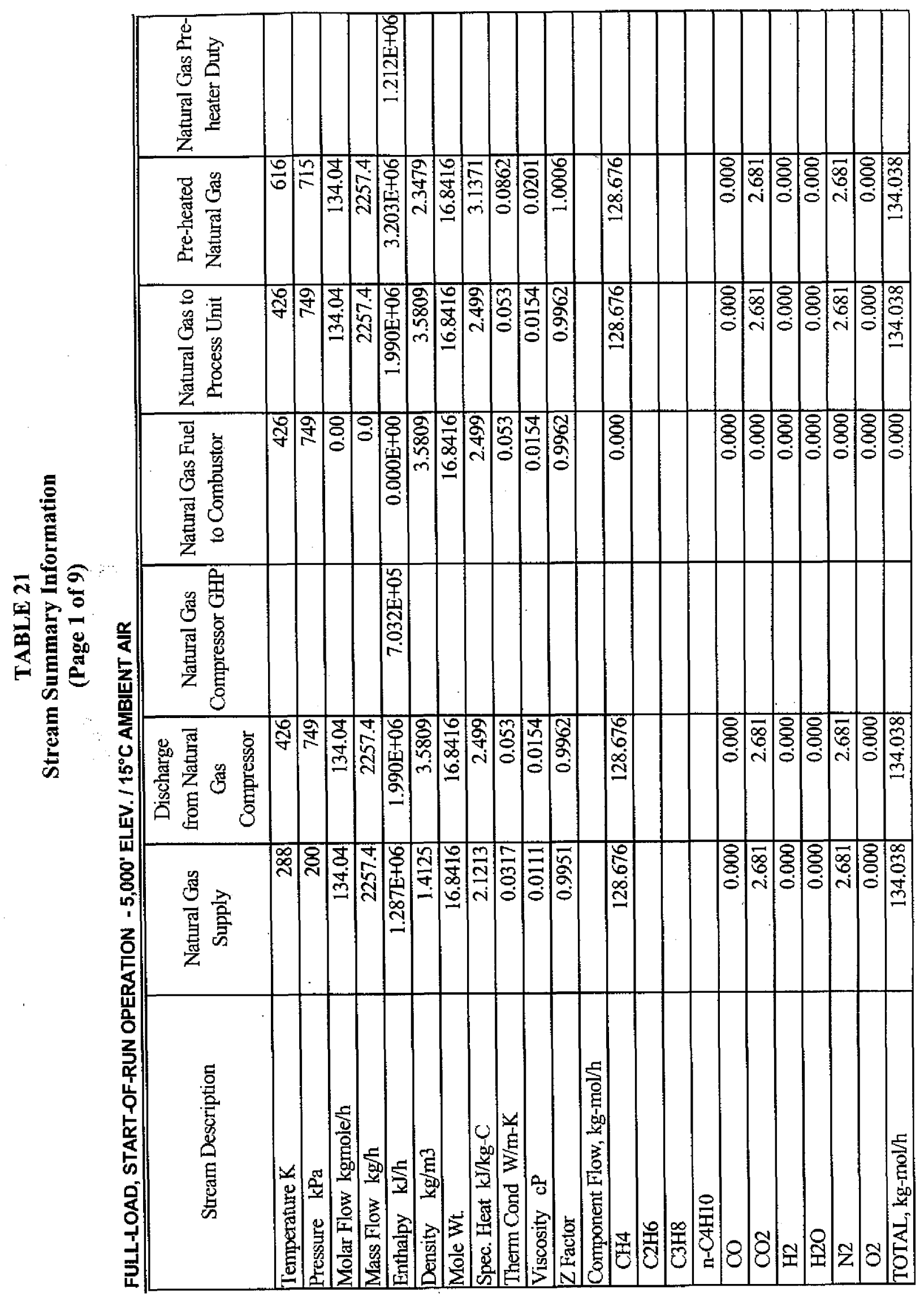

$B$
$\dot{1}$
$m$ 


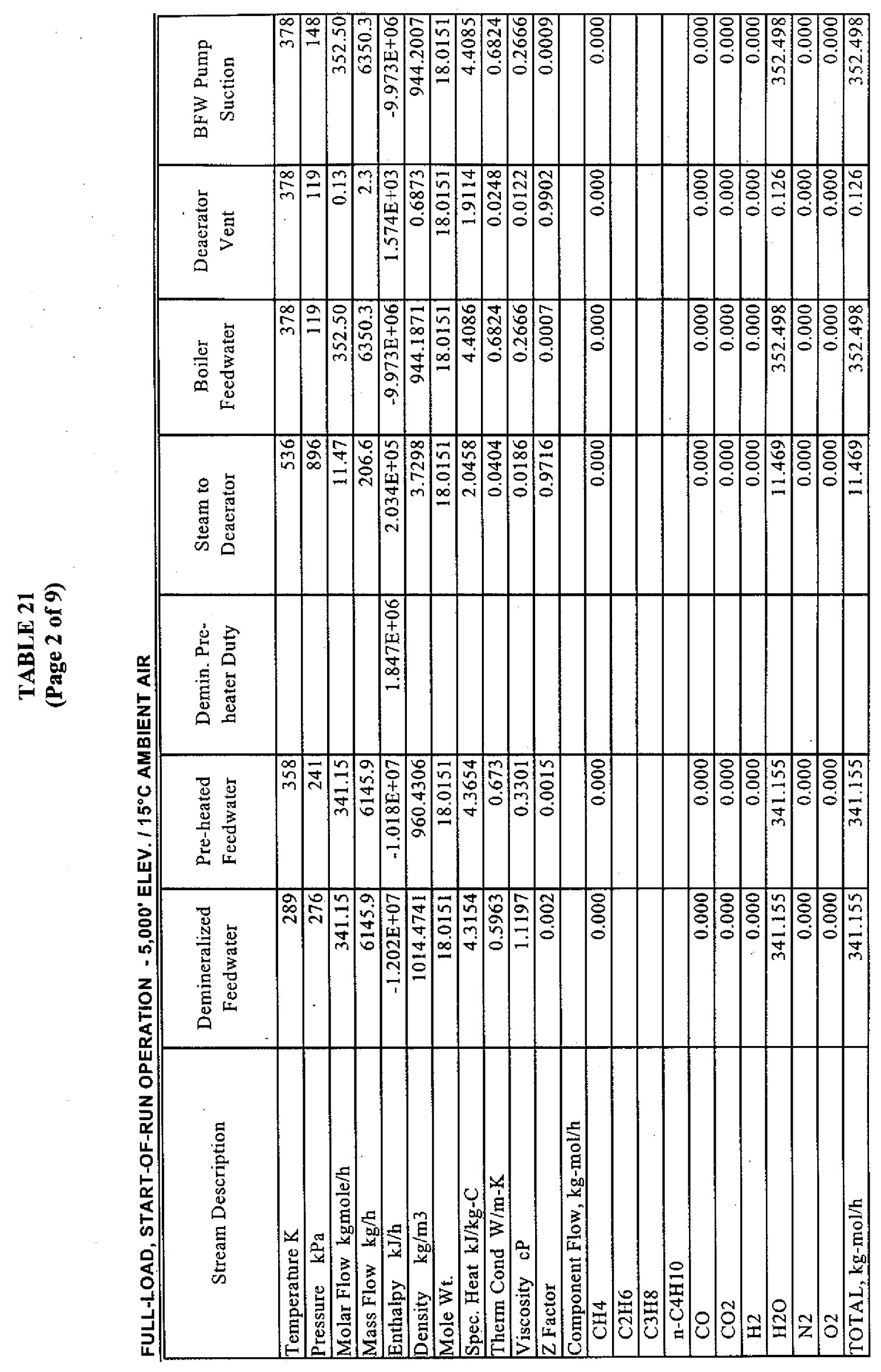




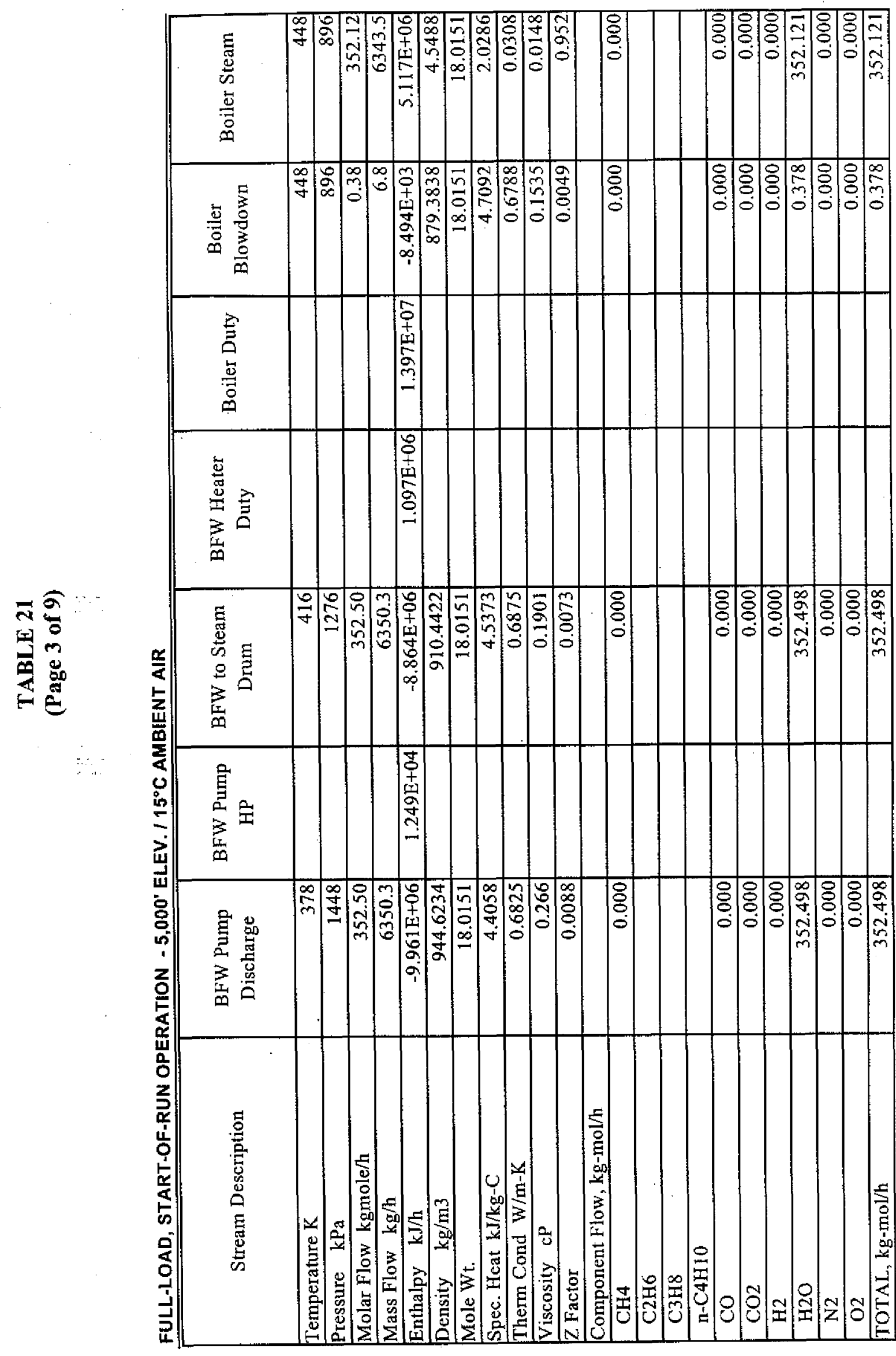




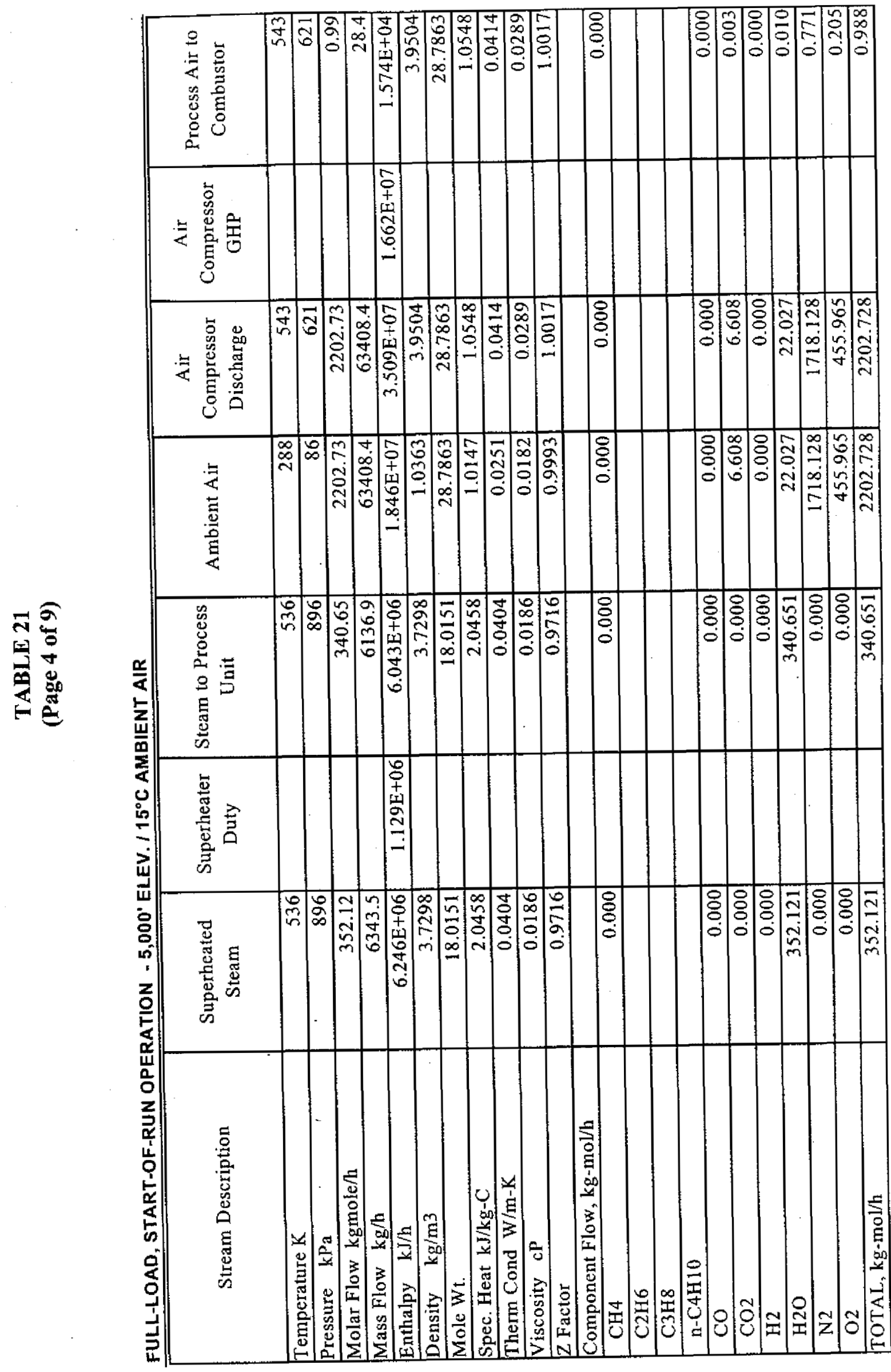




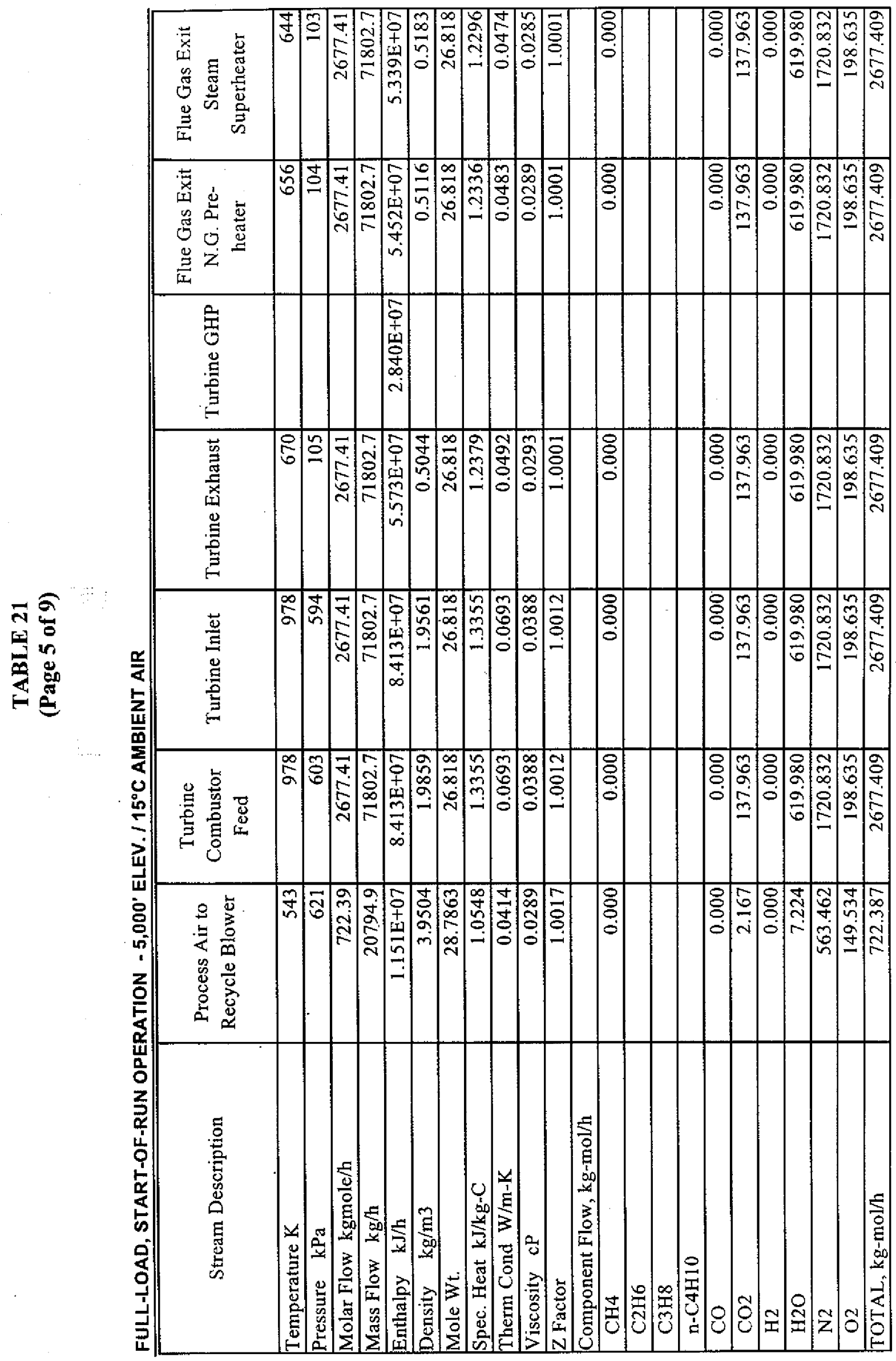




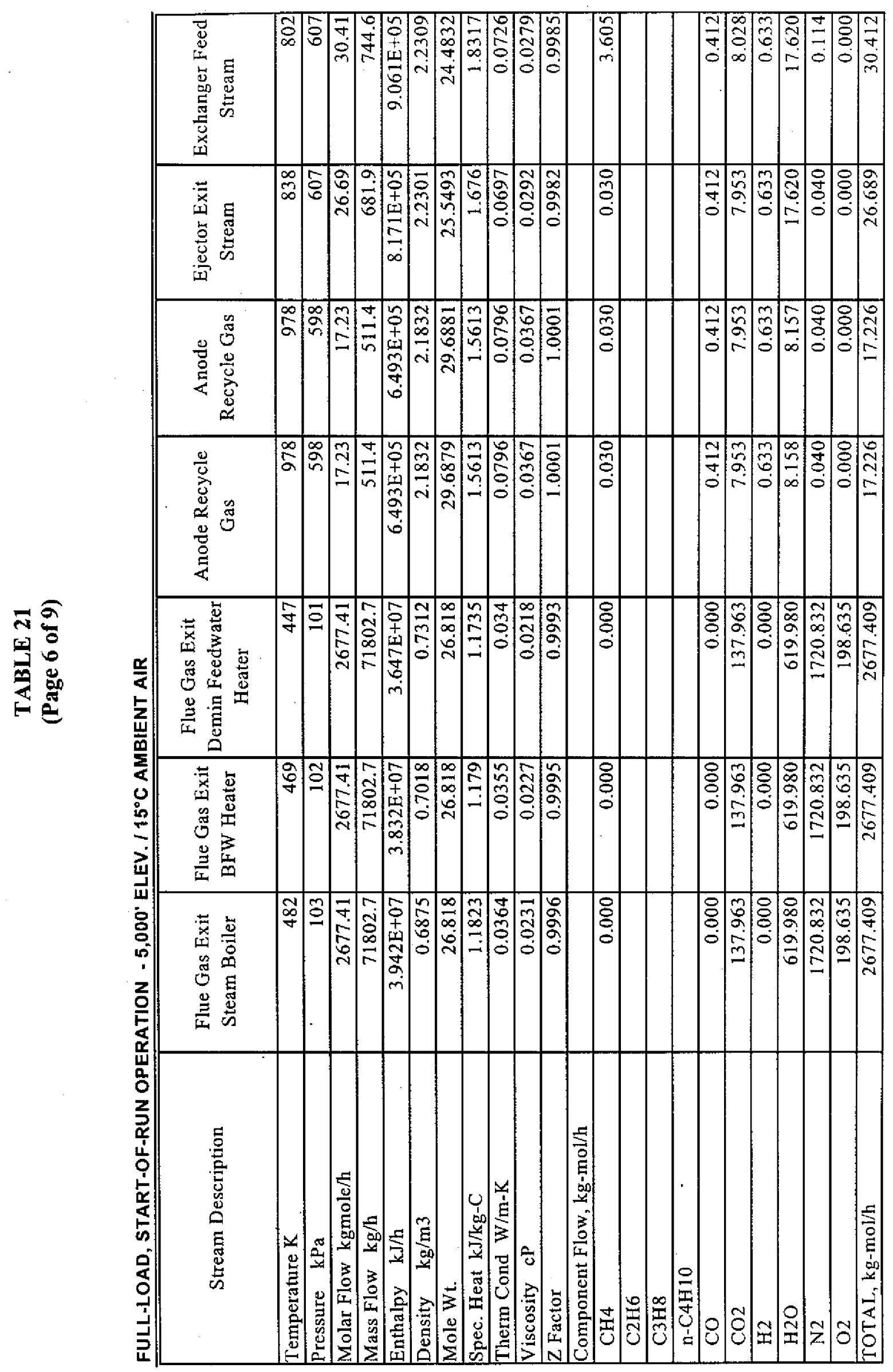




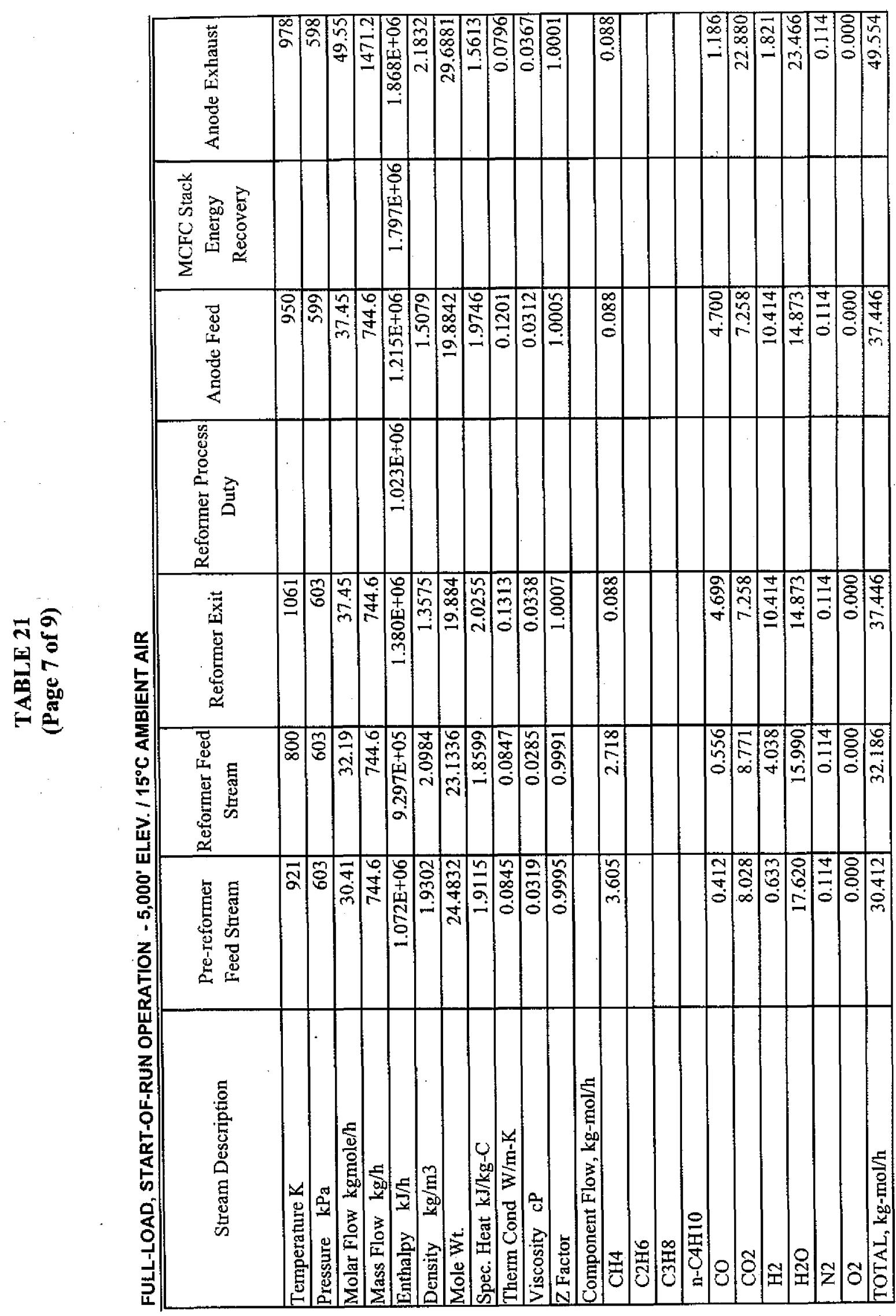

\ْ 


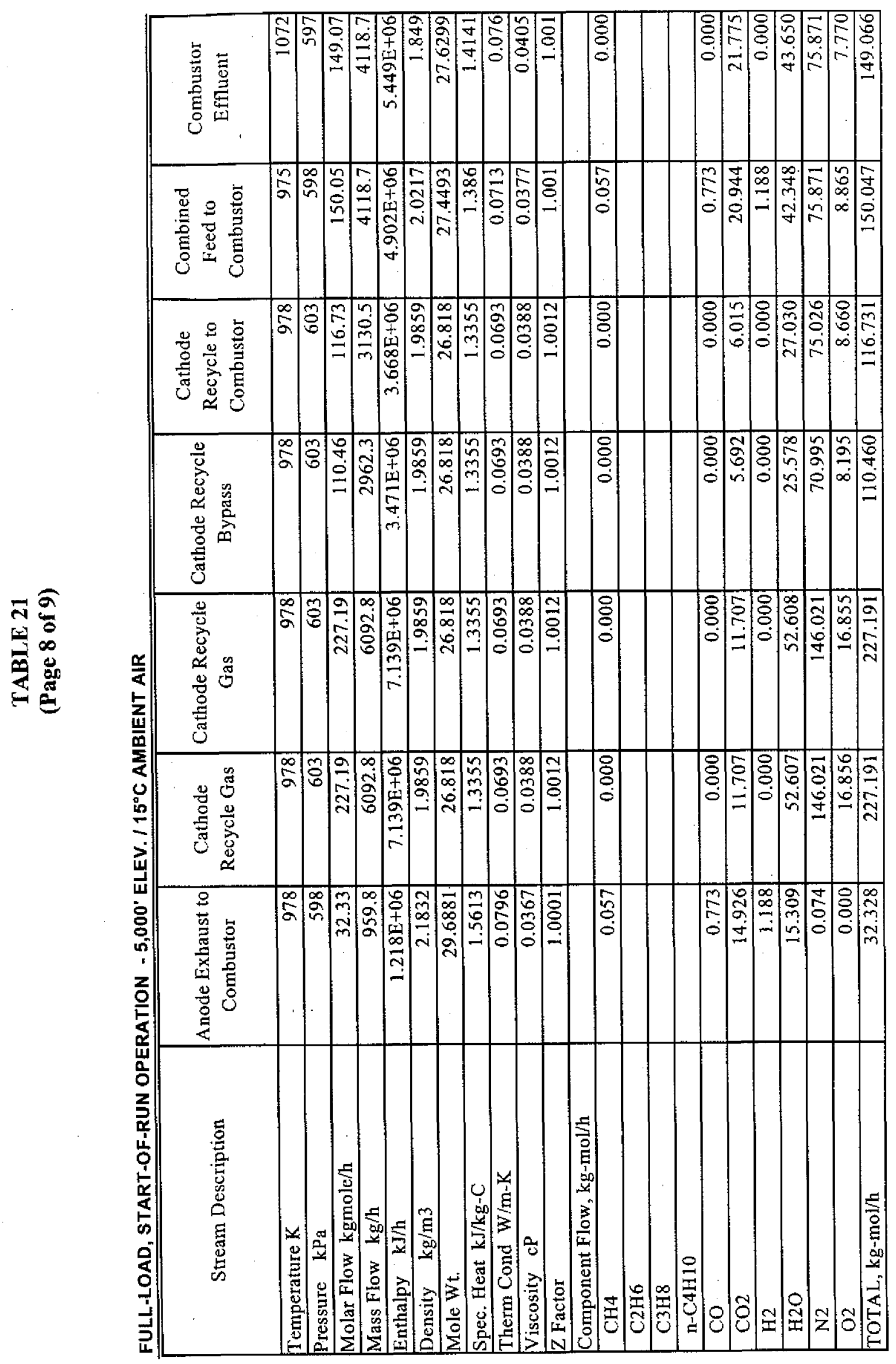




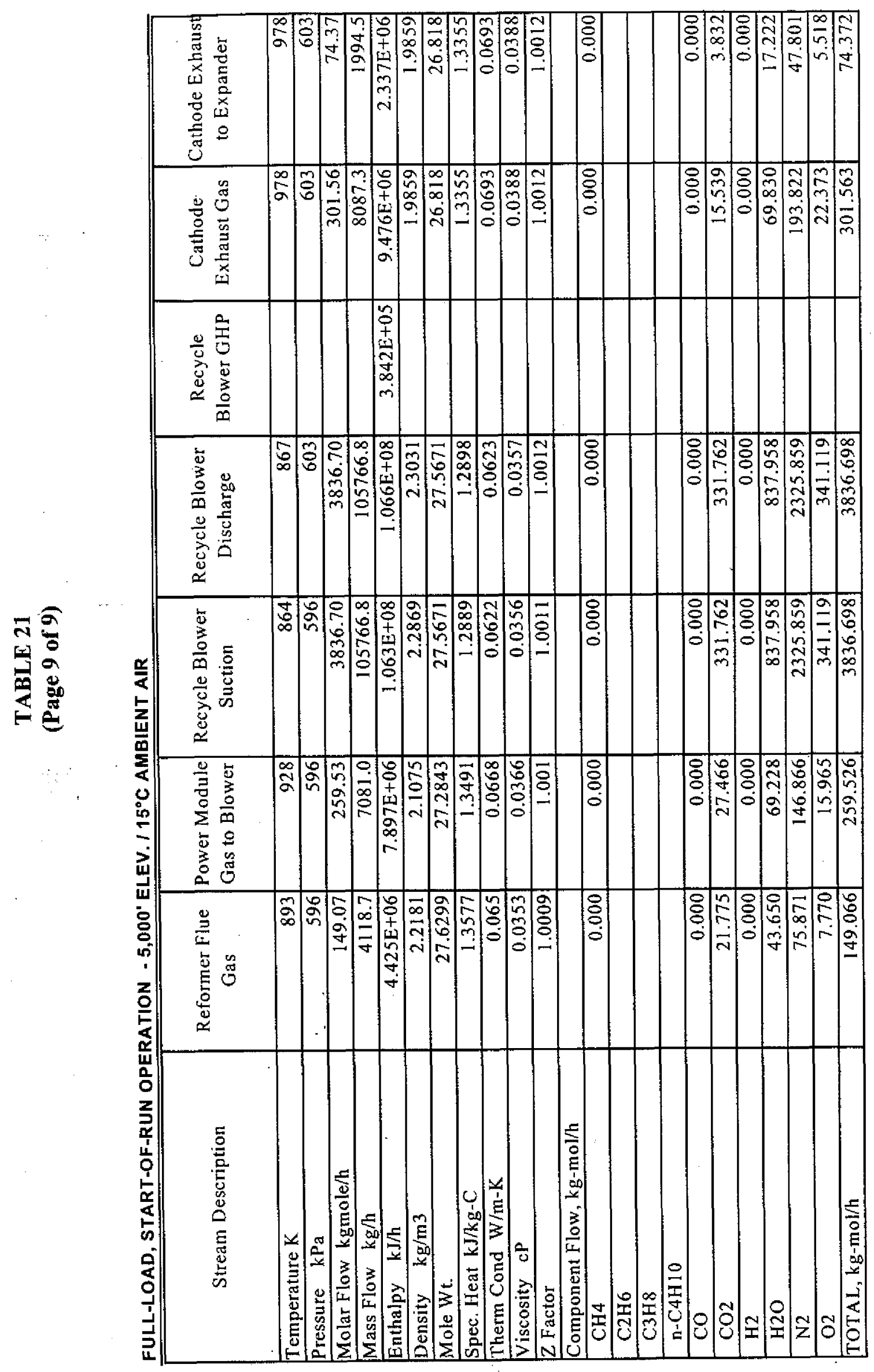




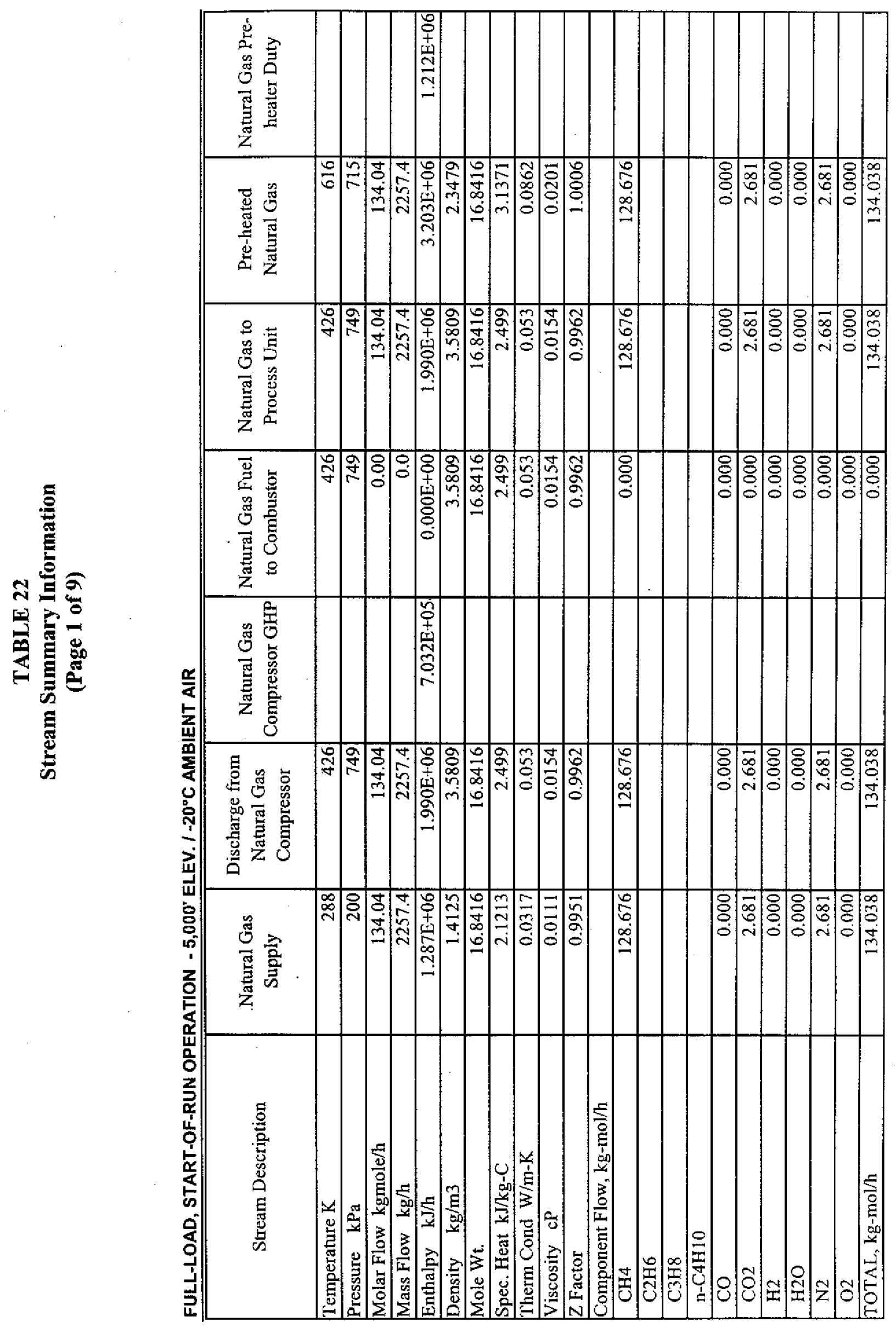

$\frac{N}{n}$ 


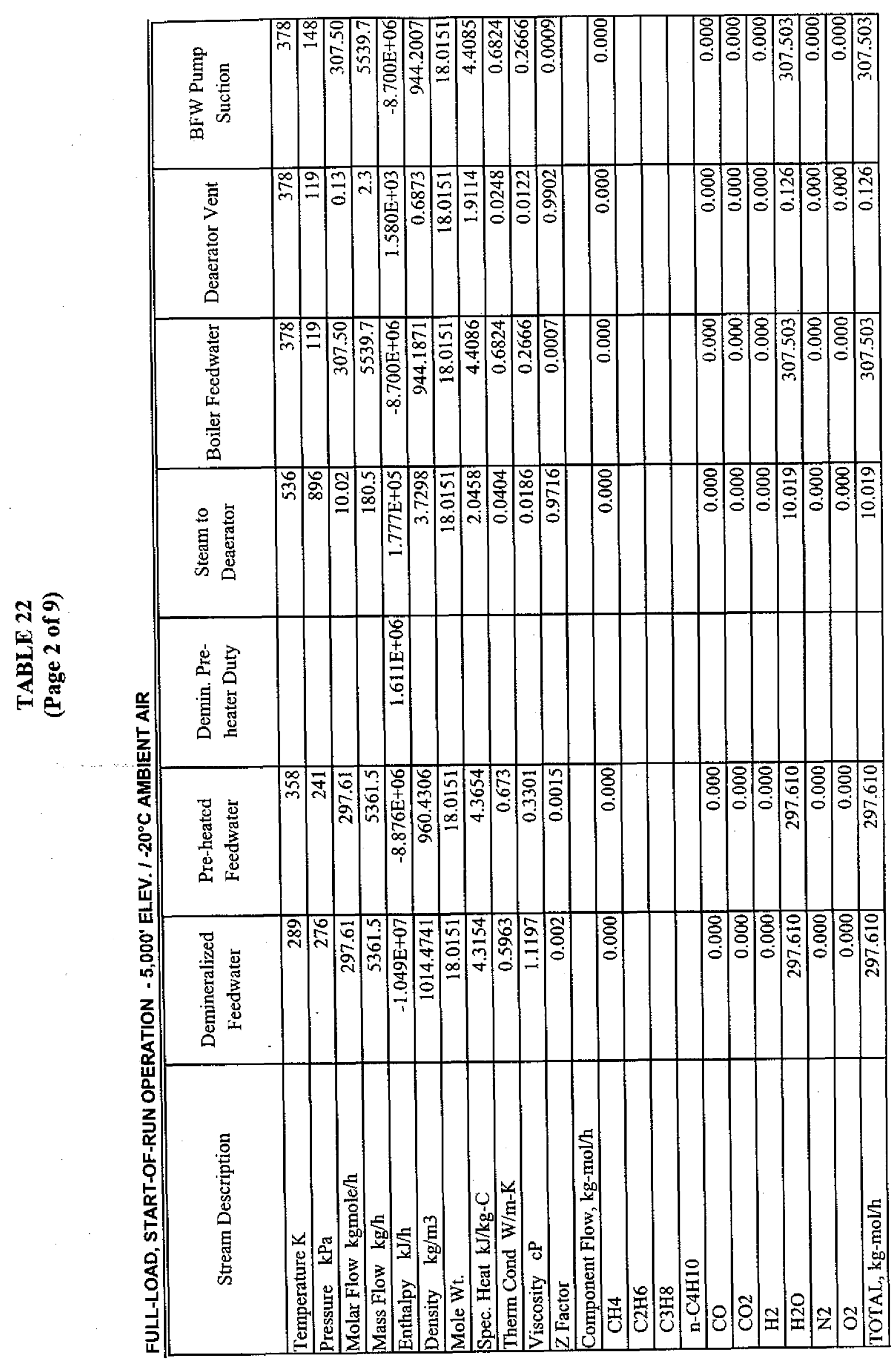

क. 


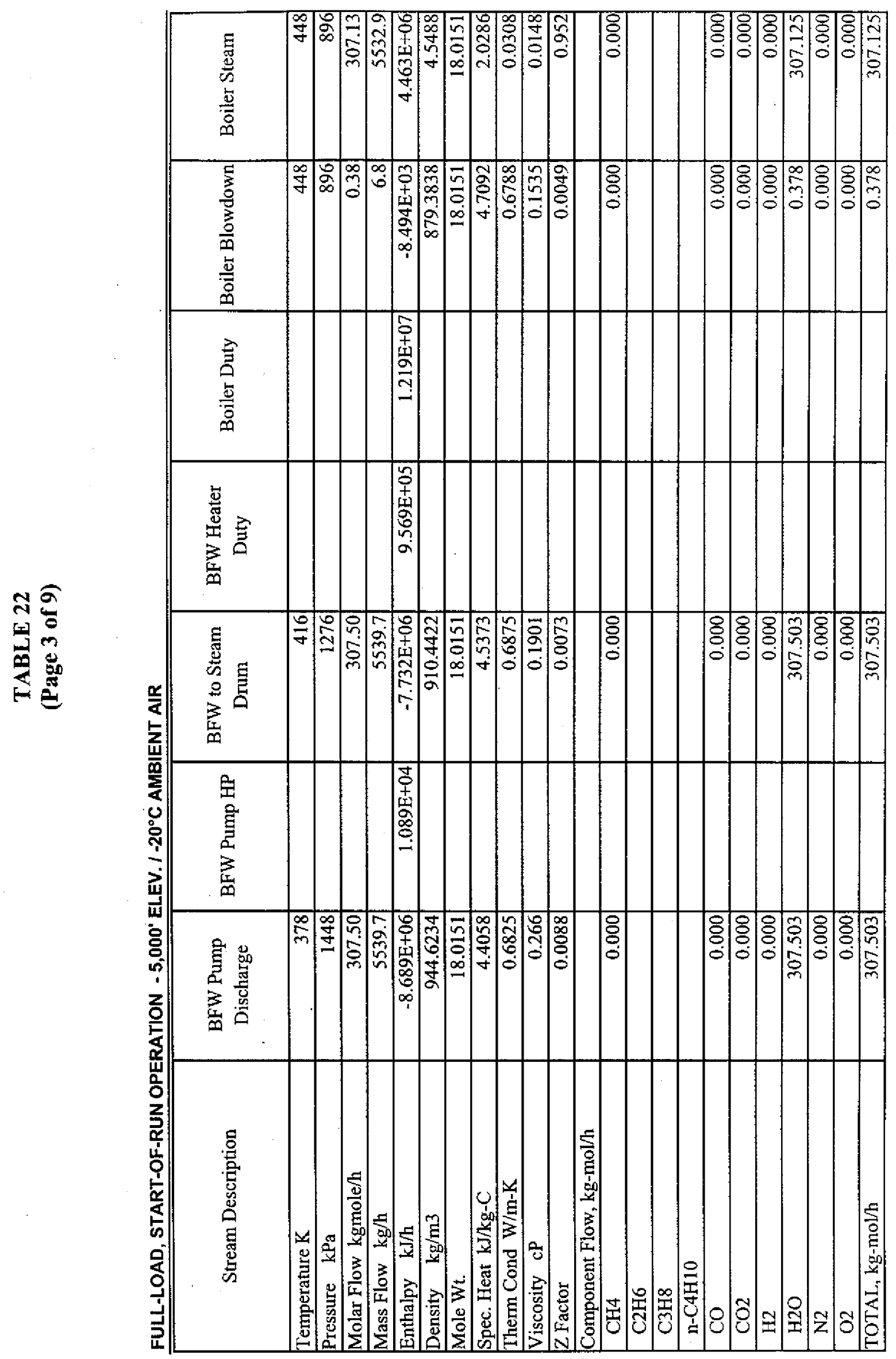




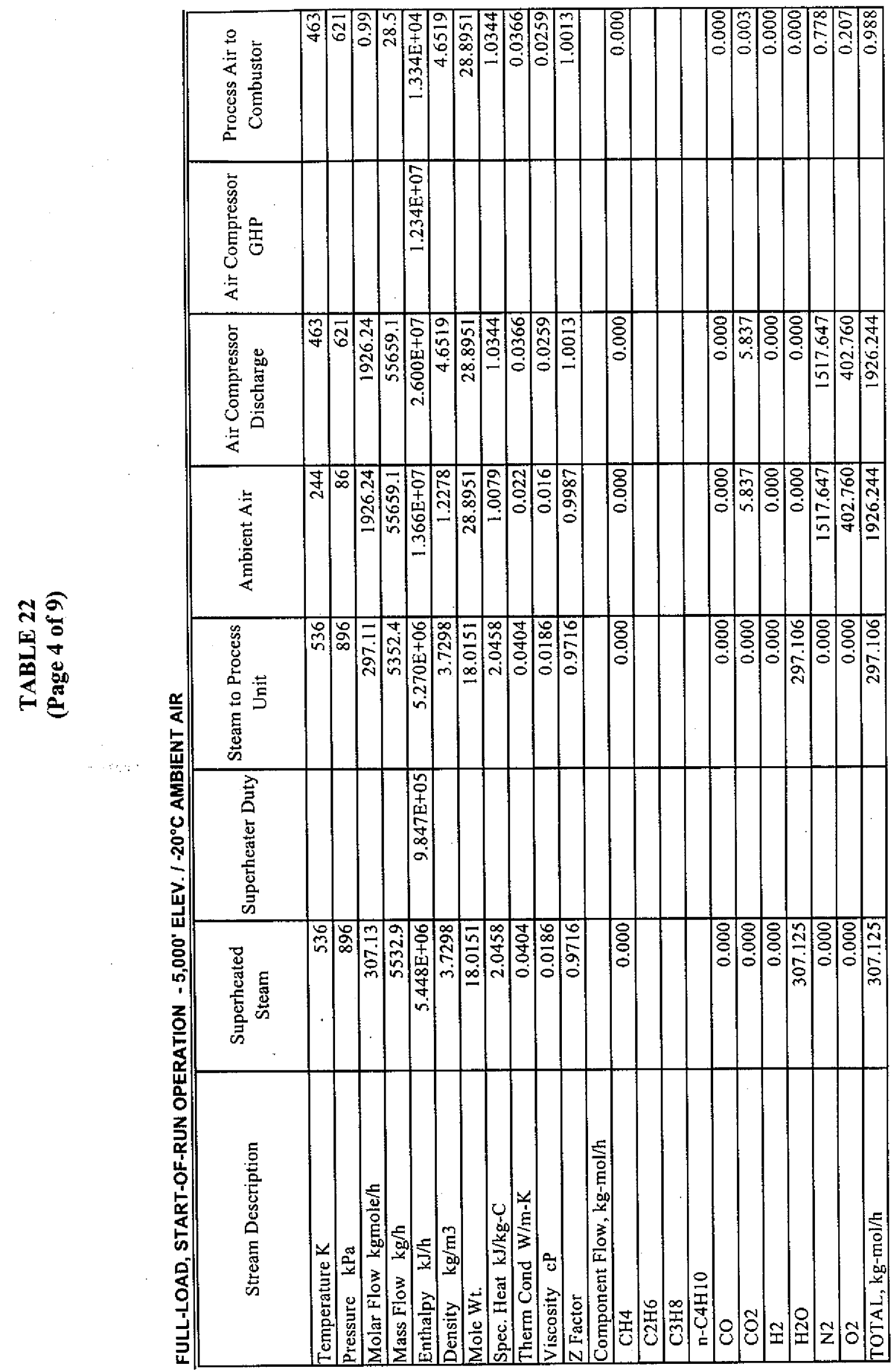




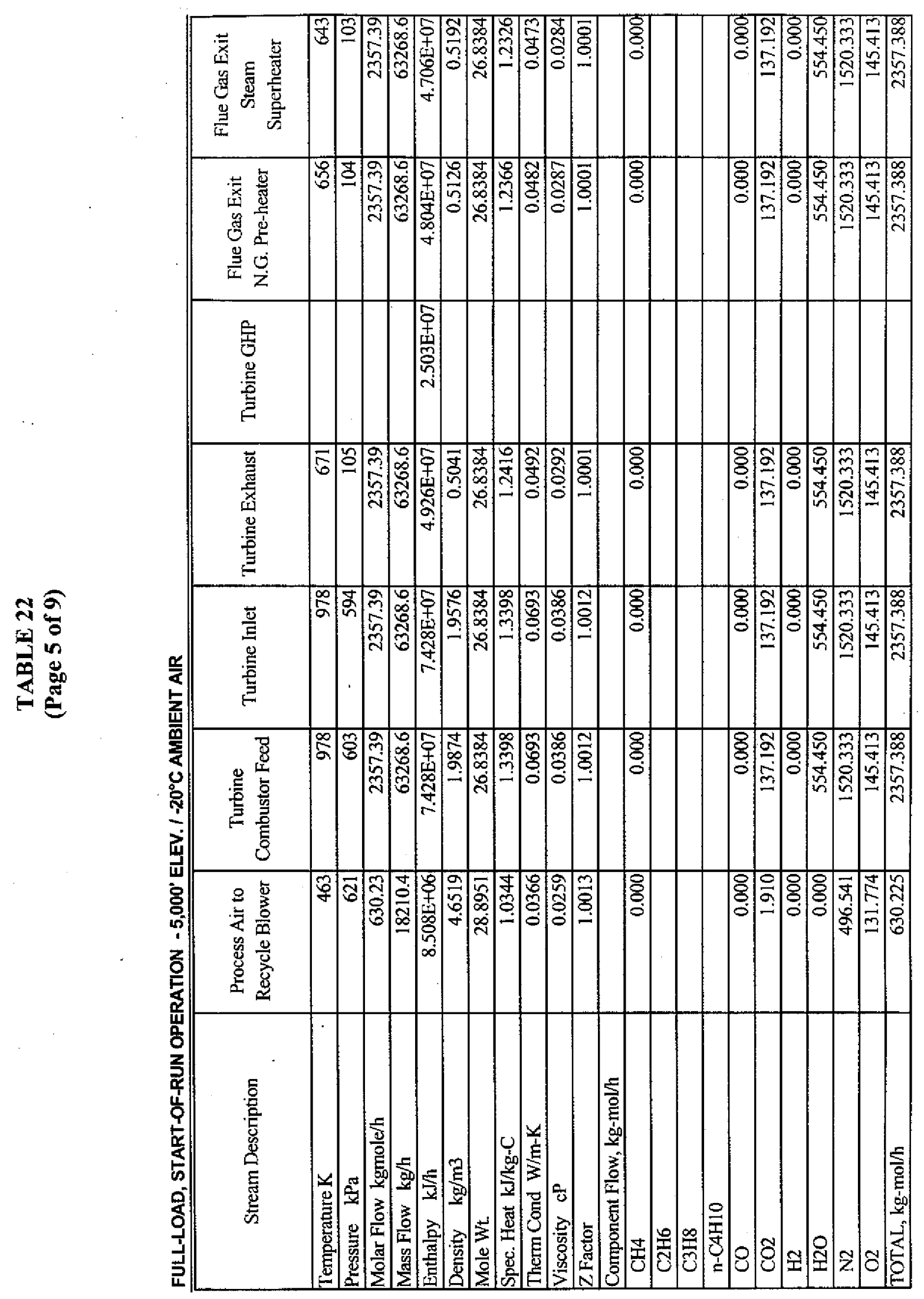

官 


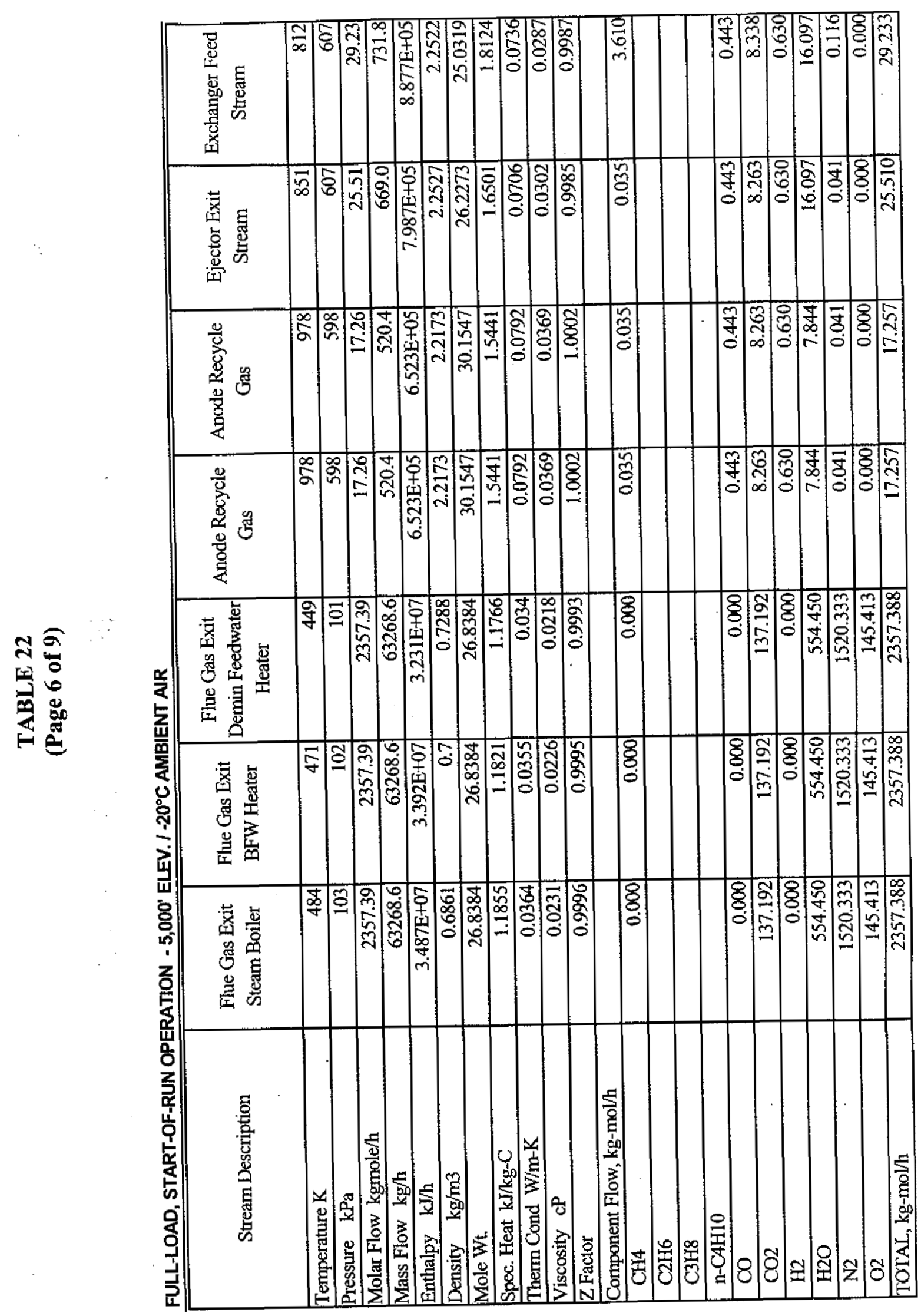

点 


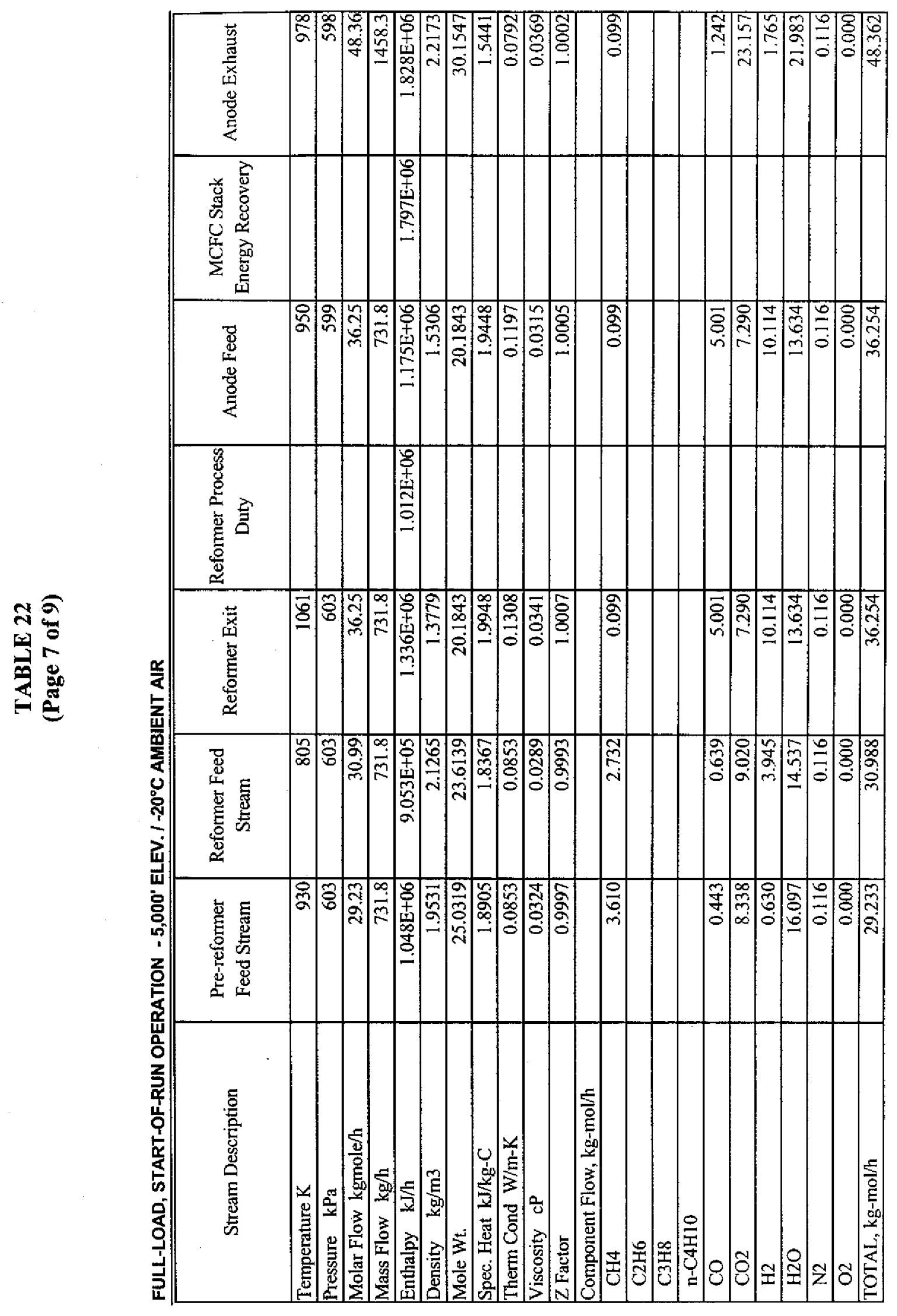




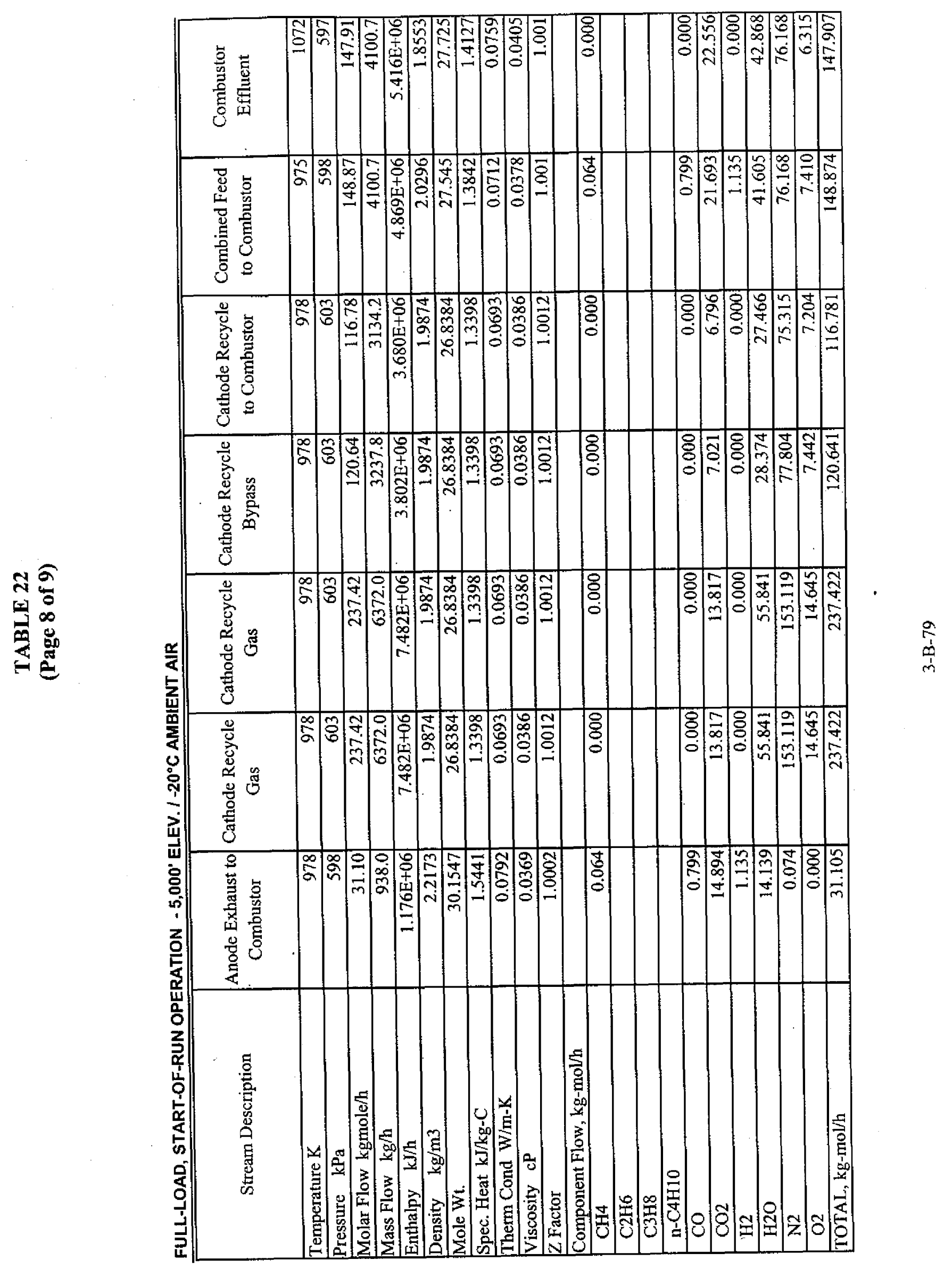




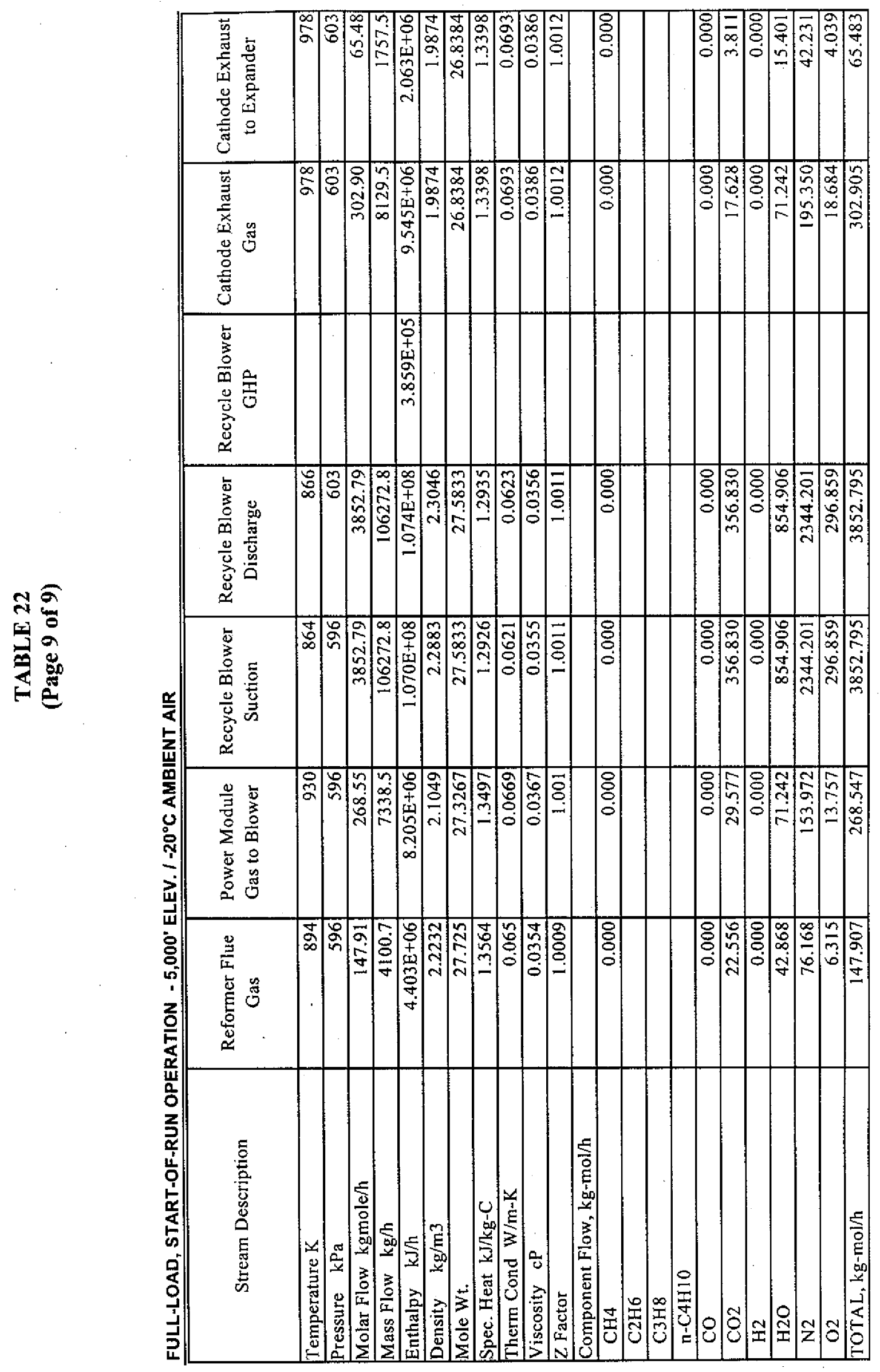




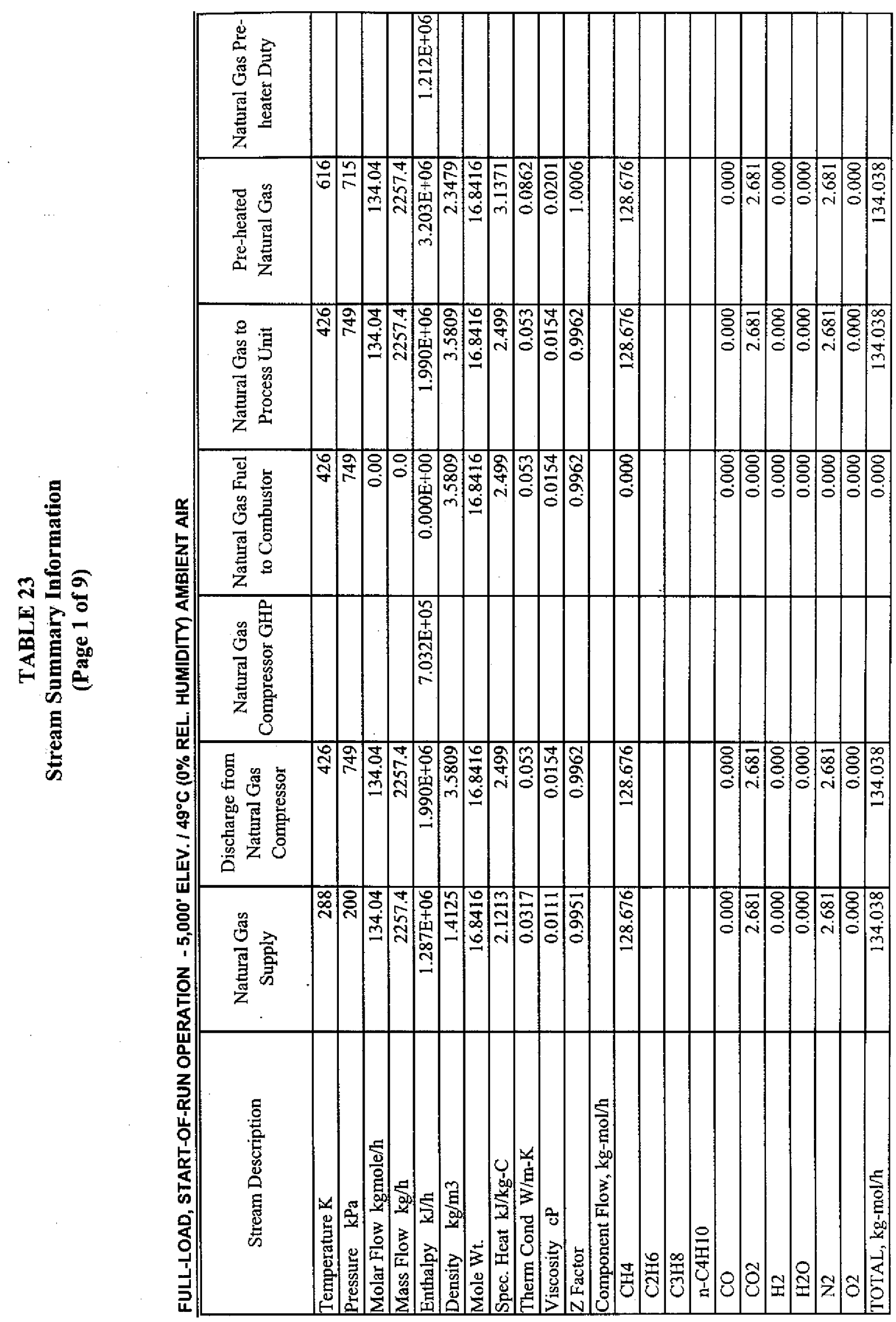




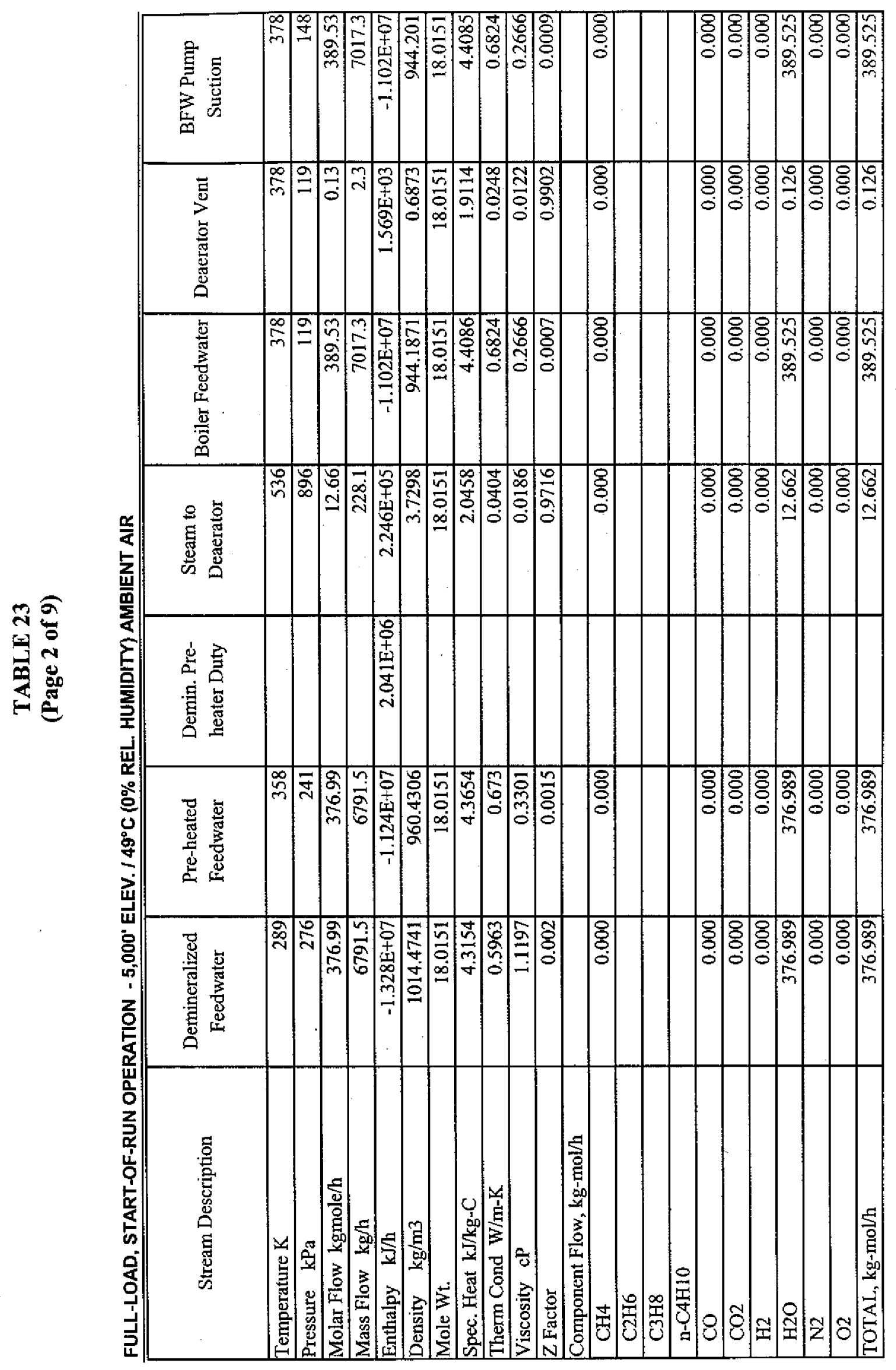




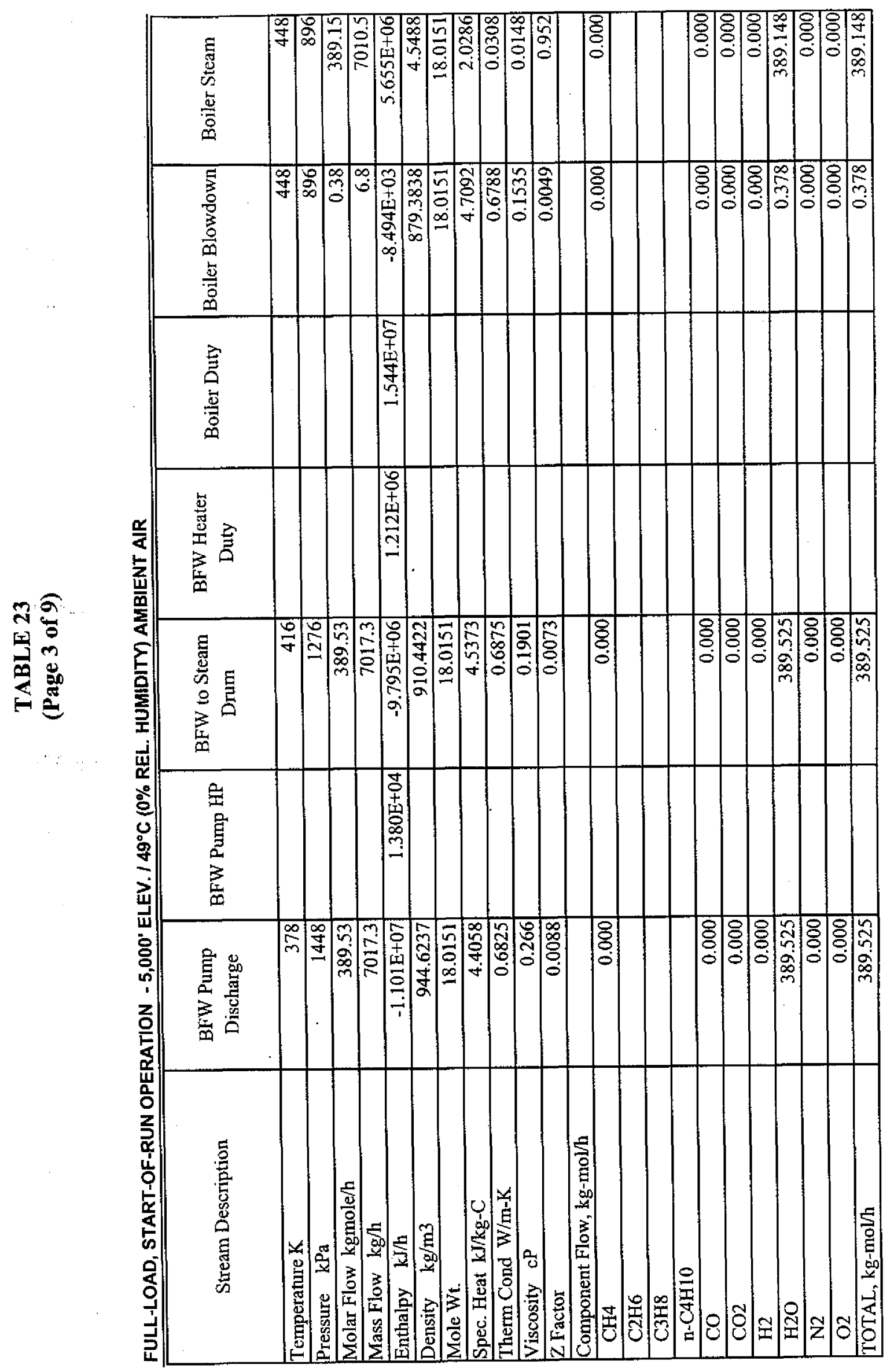




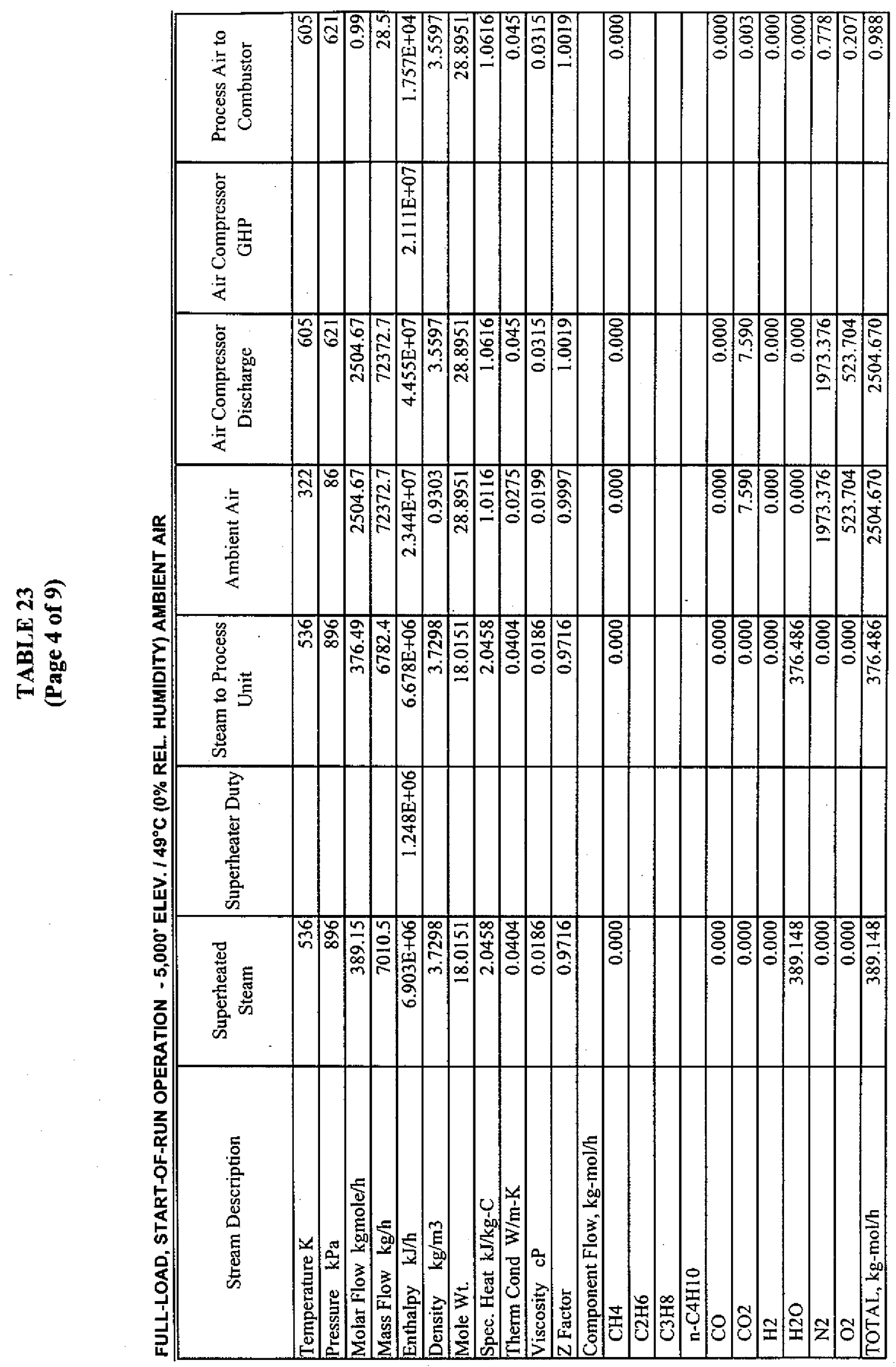




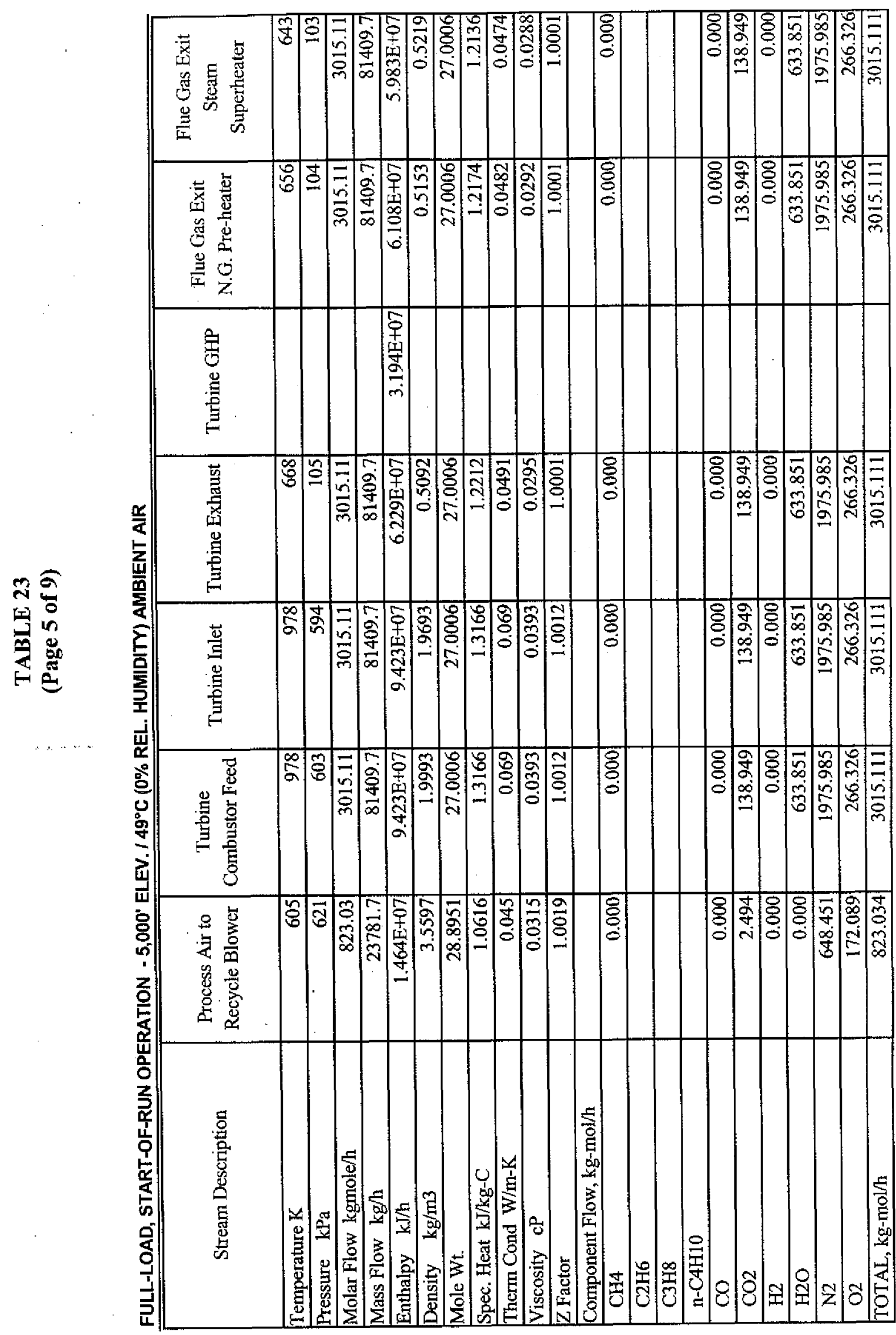




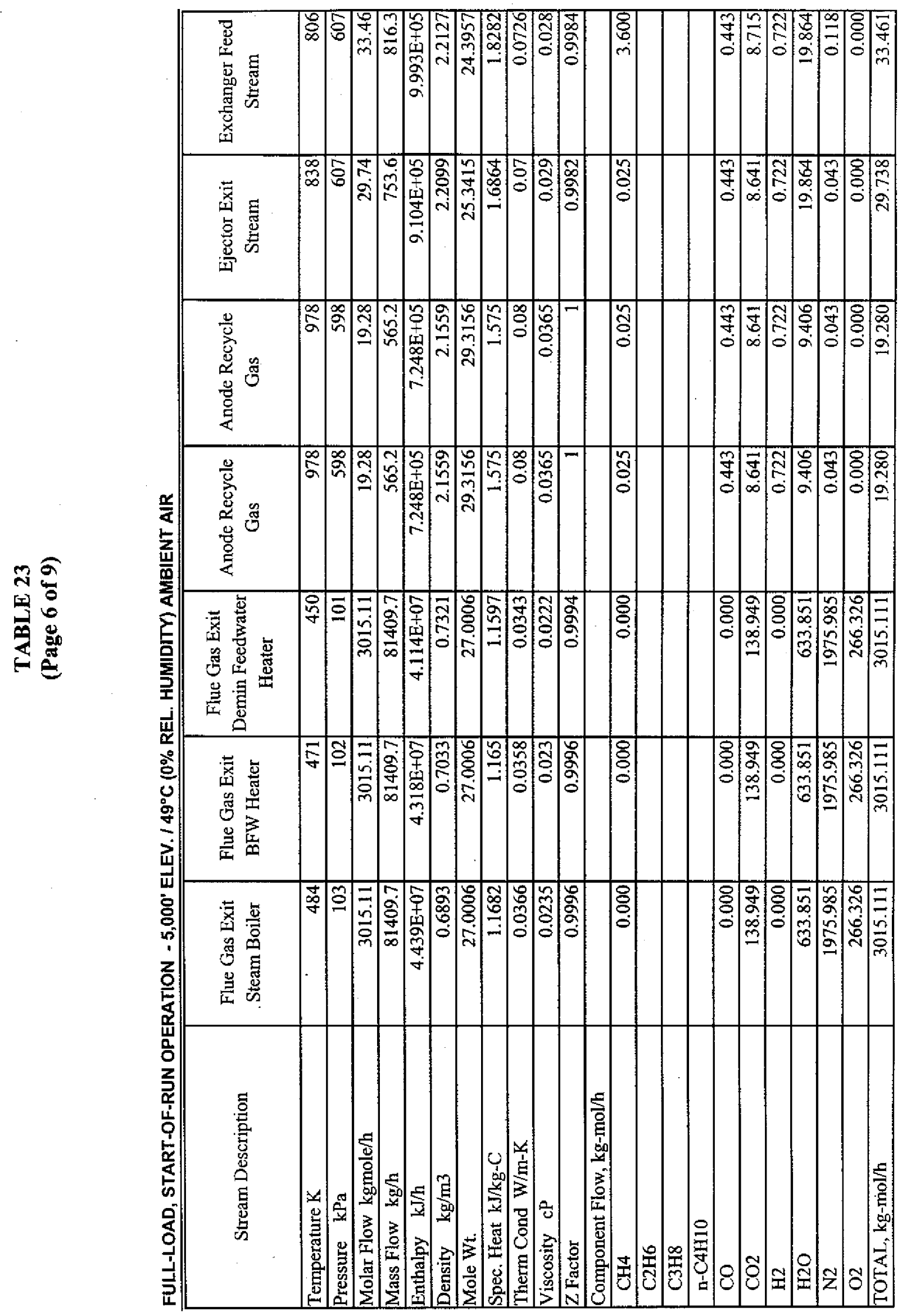




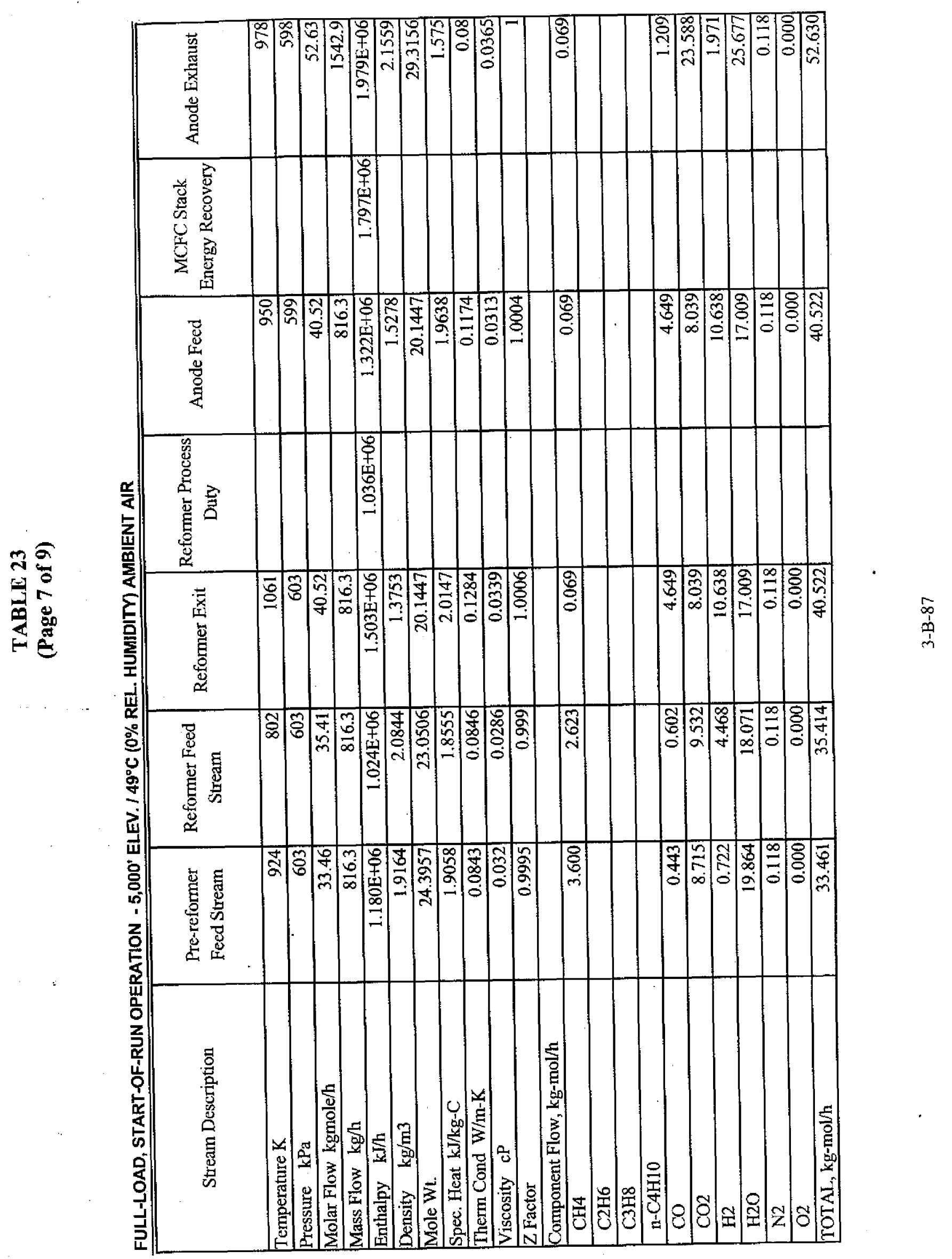




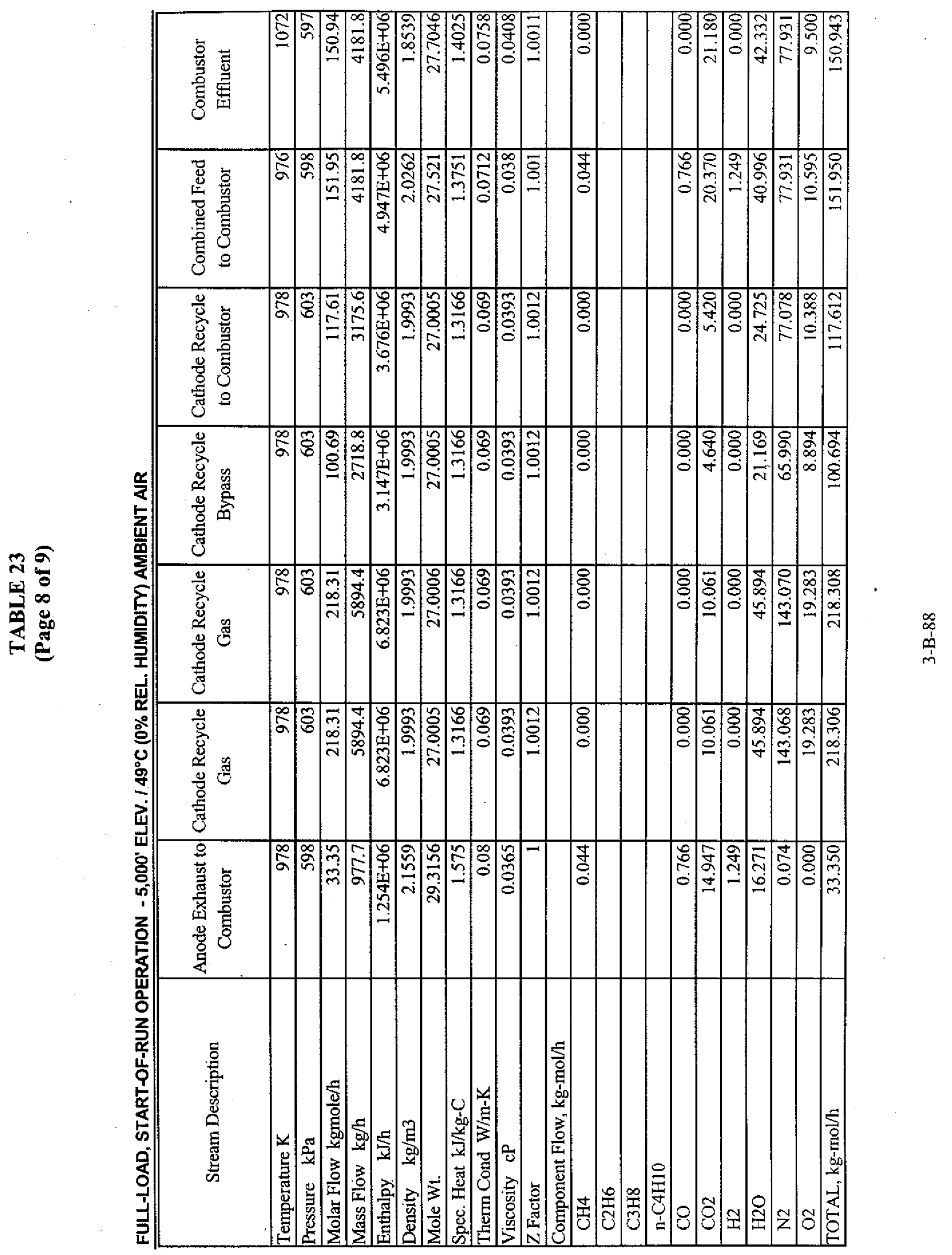




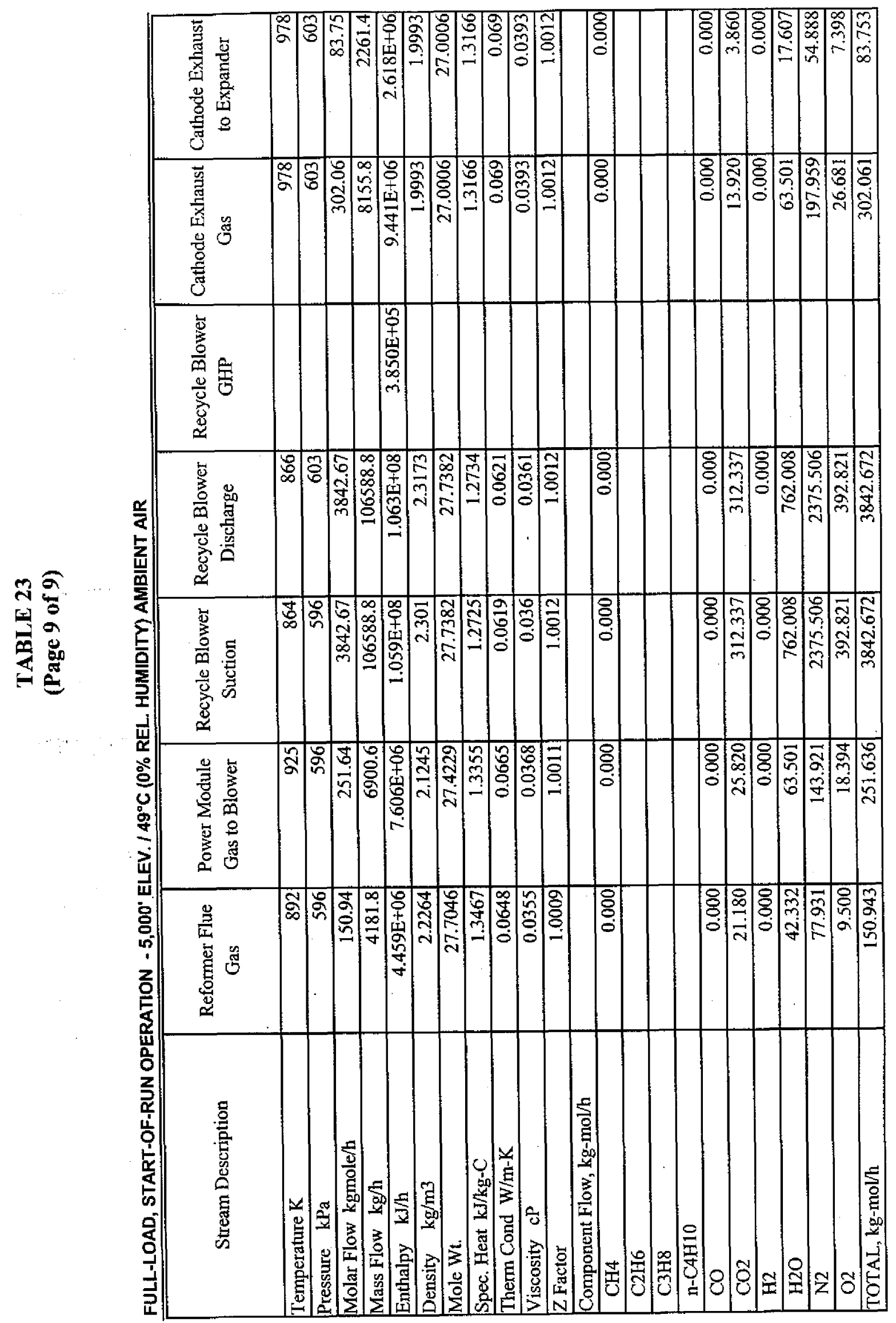




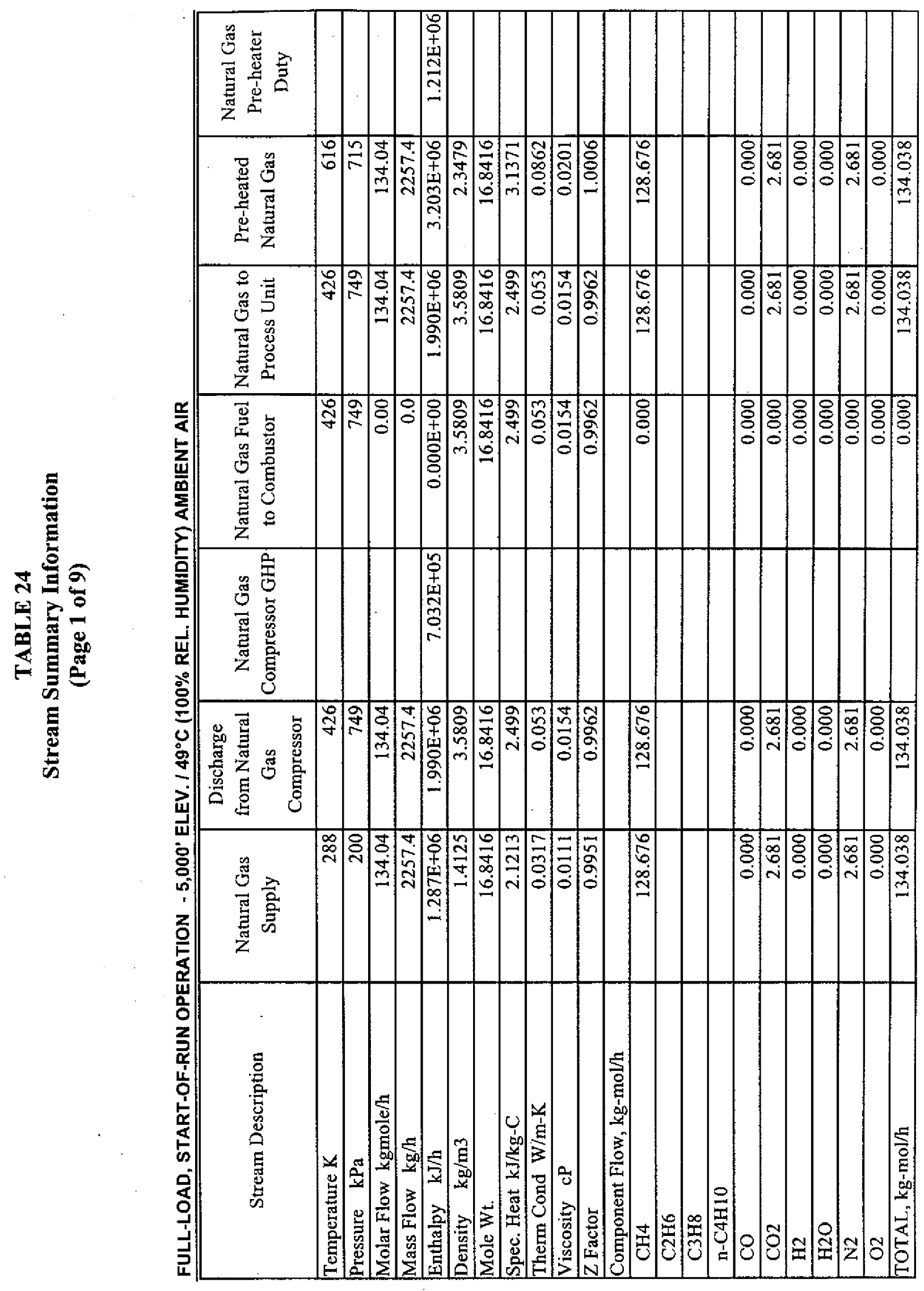




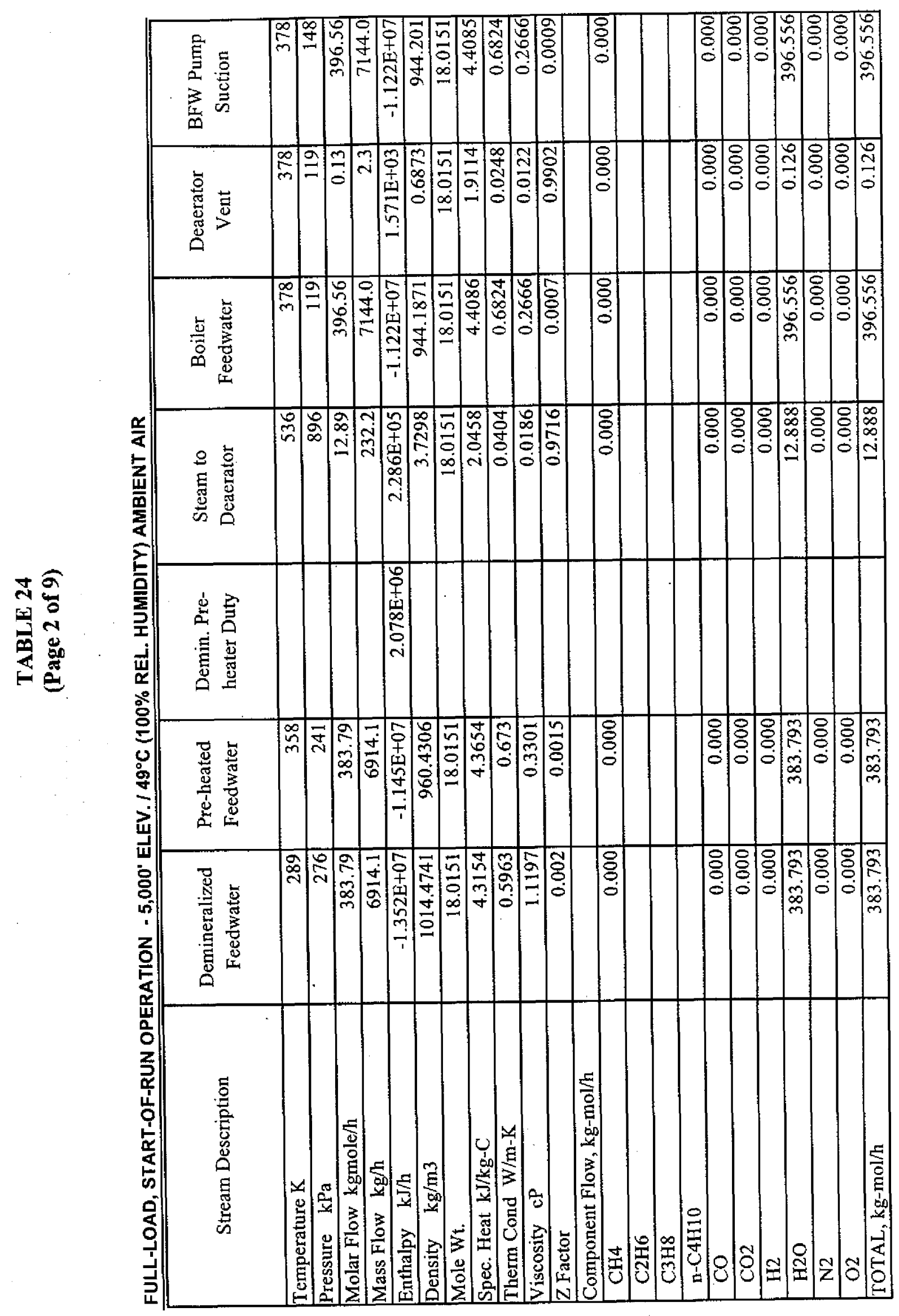




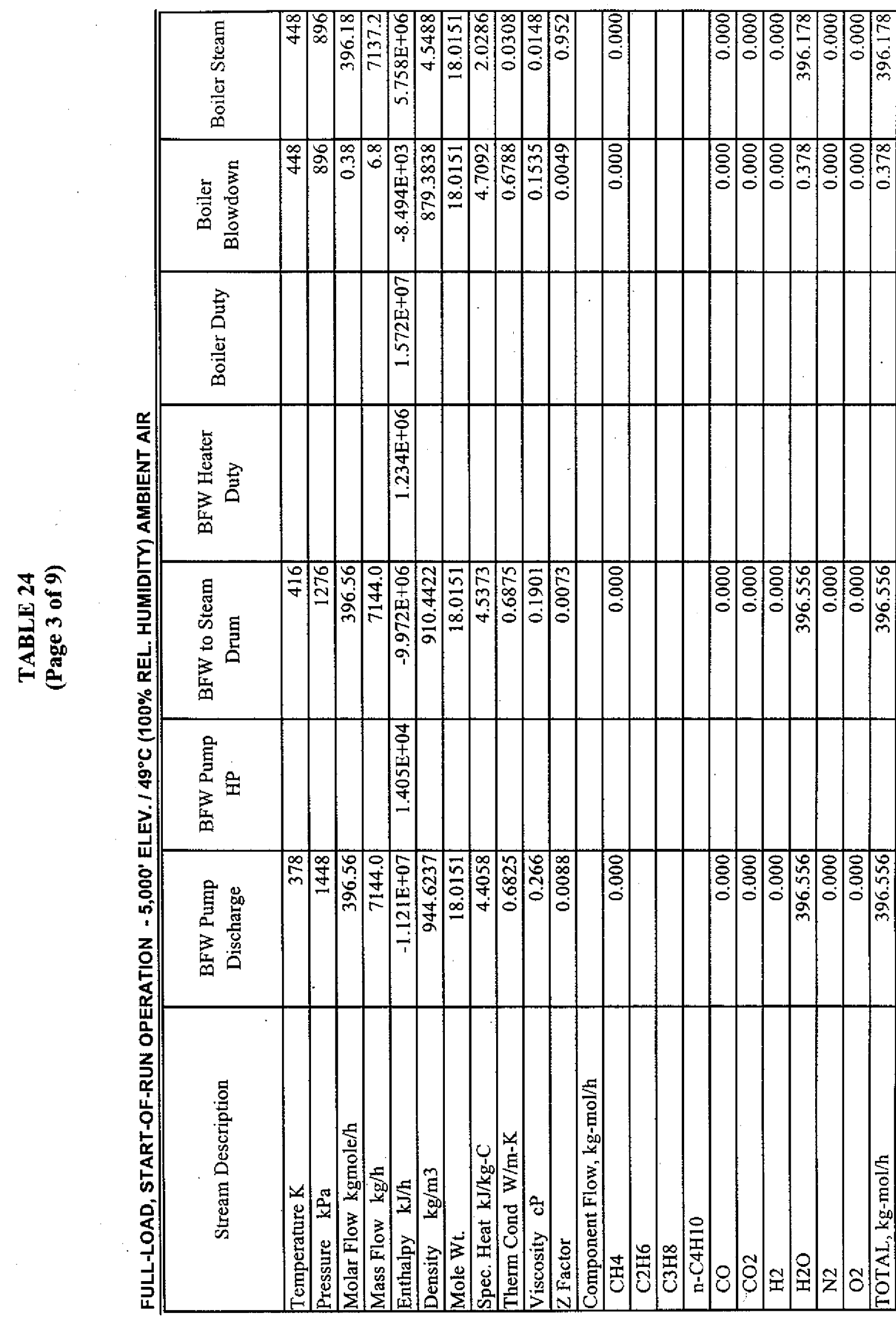




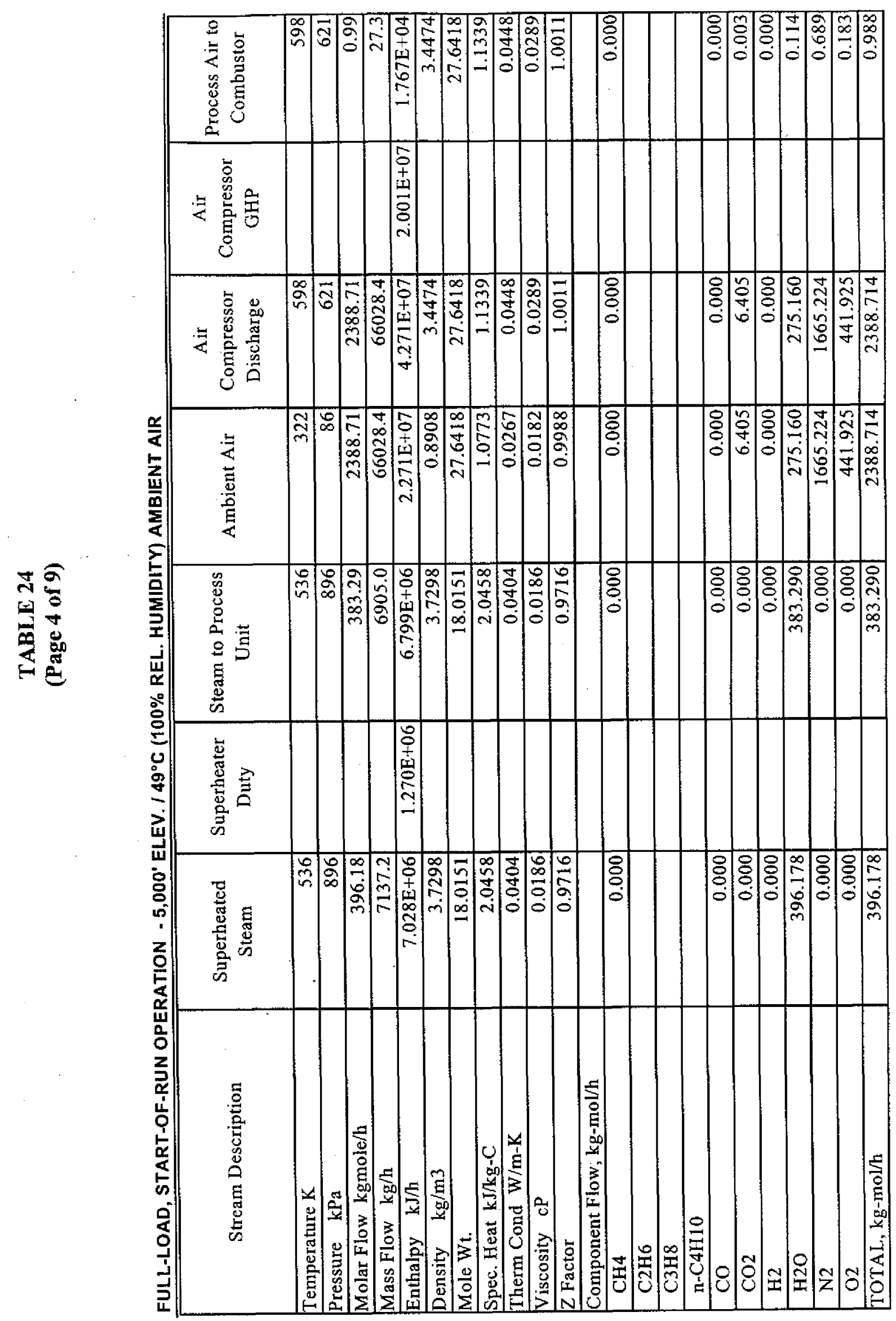




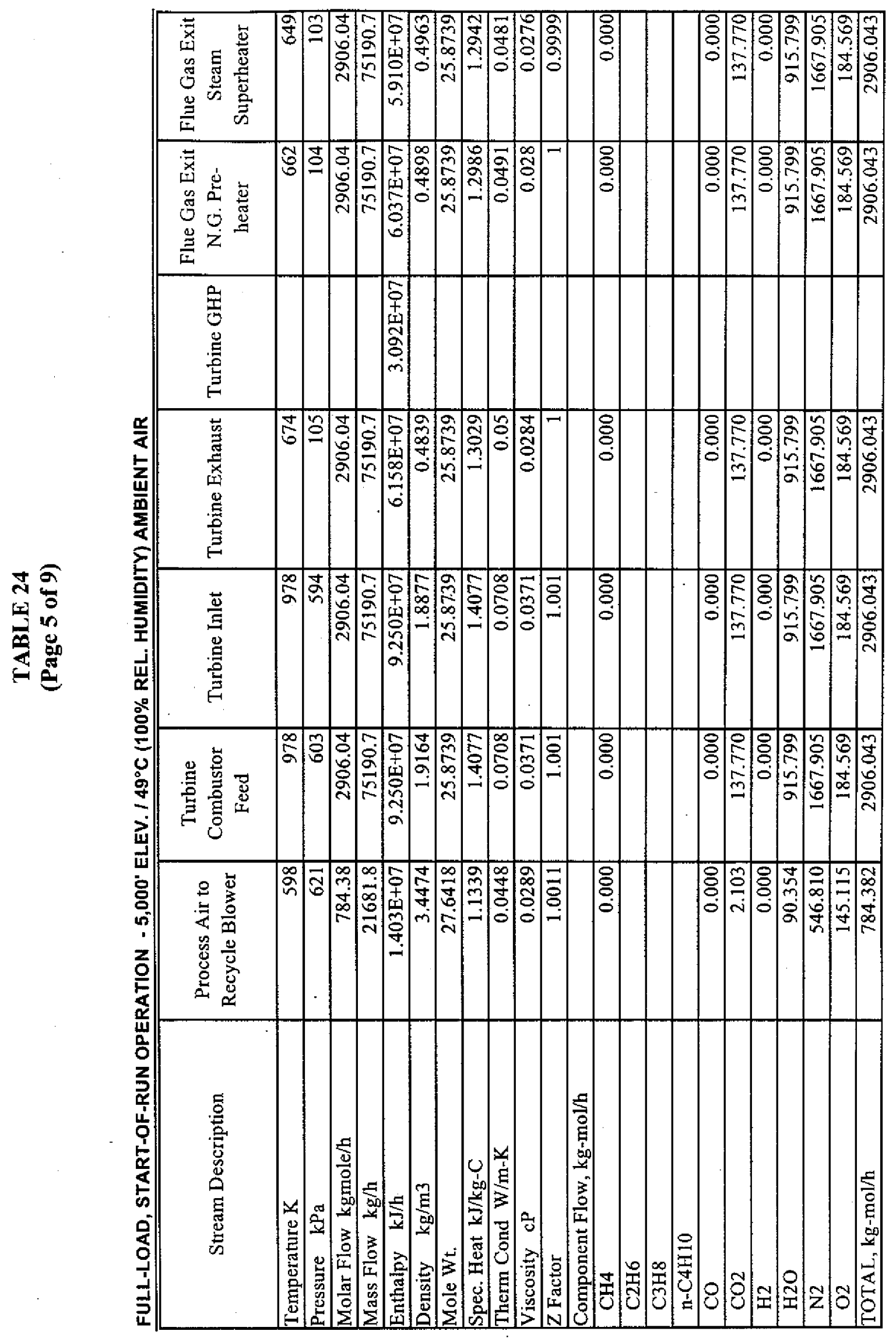




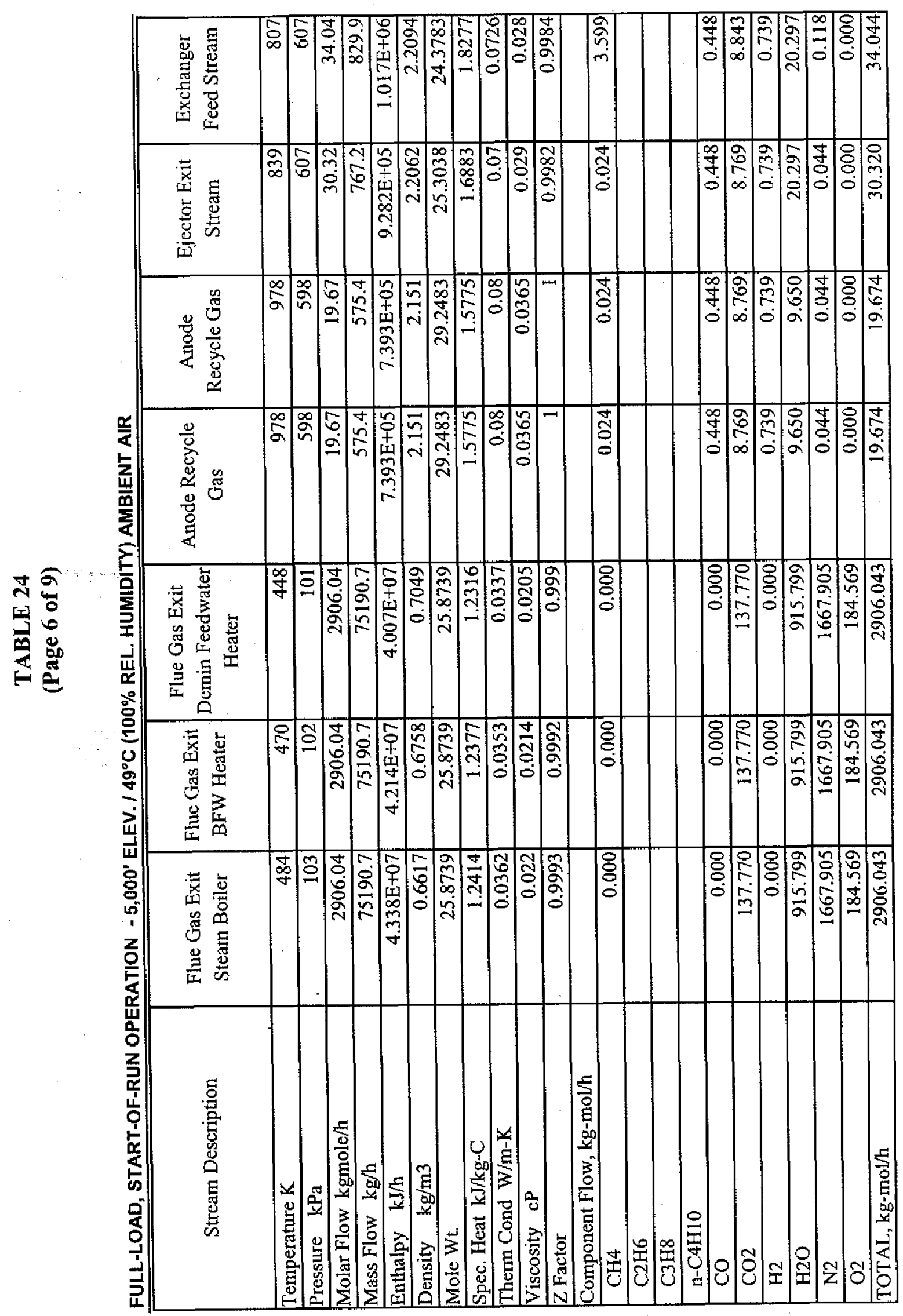




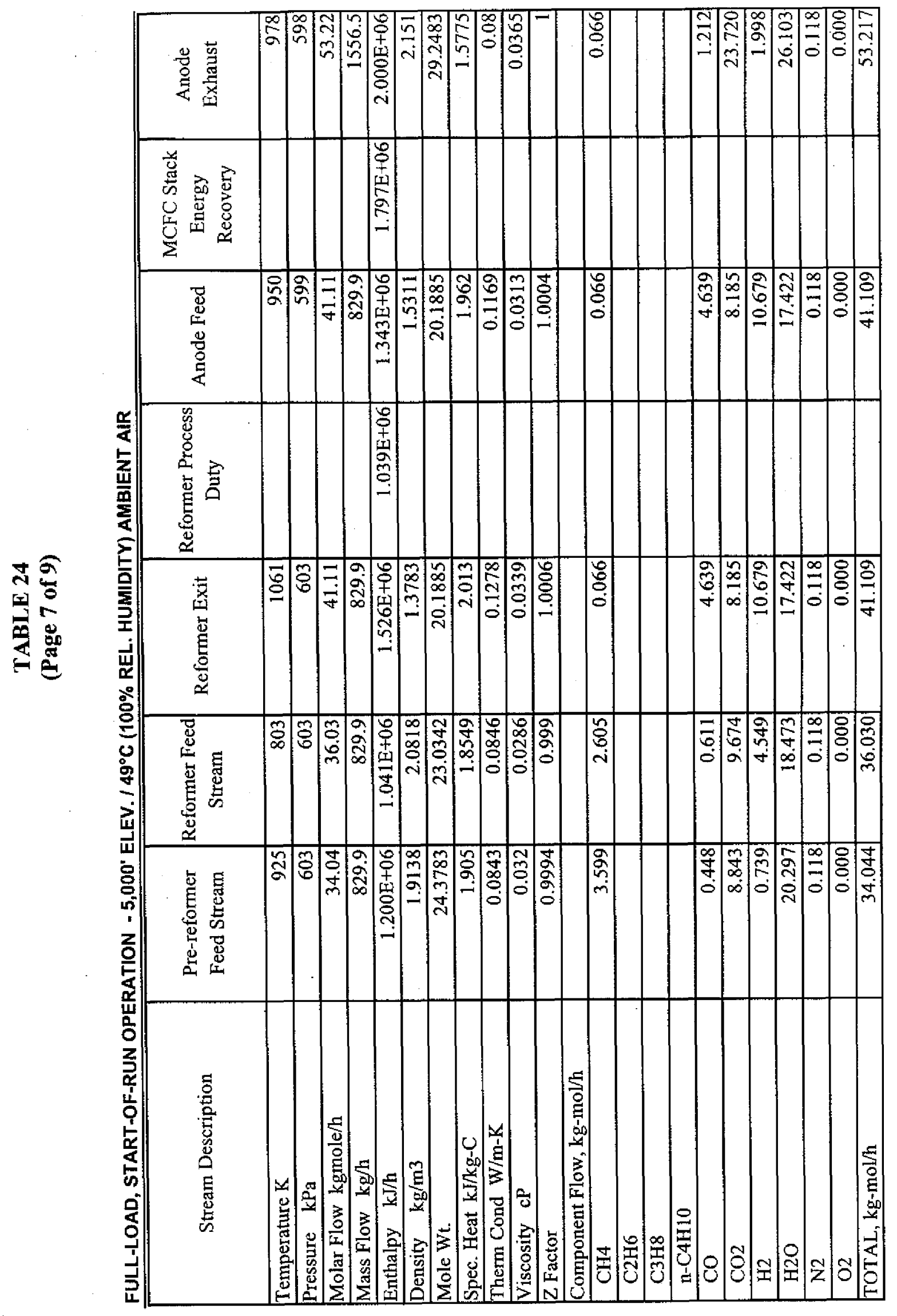




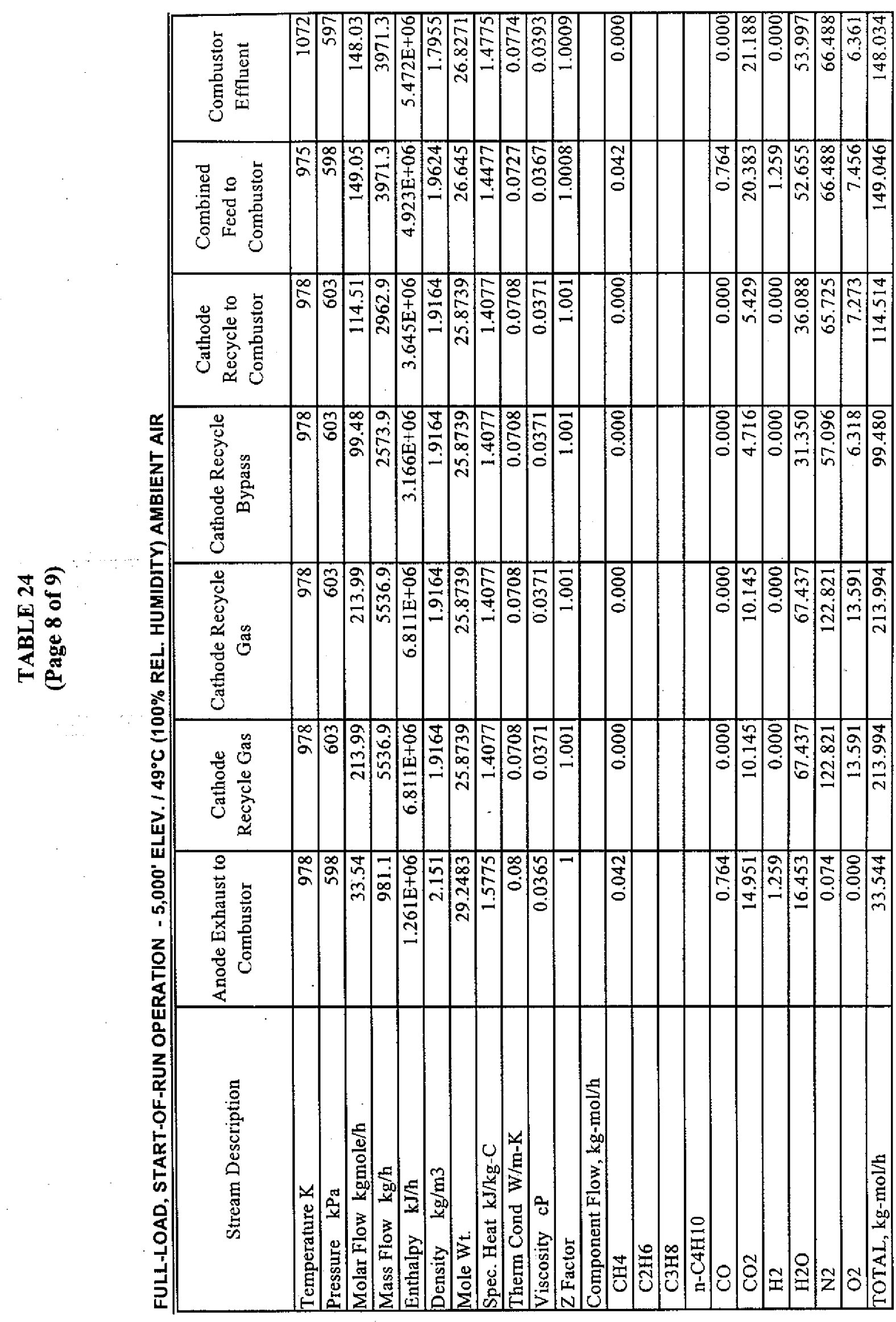




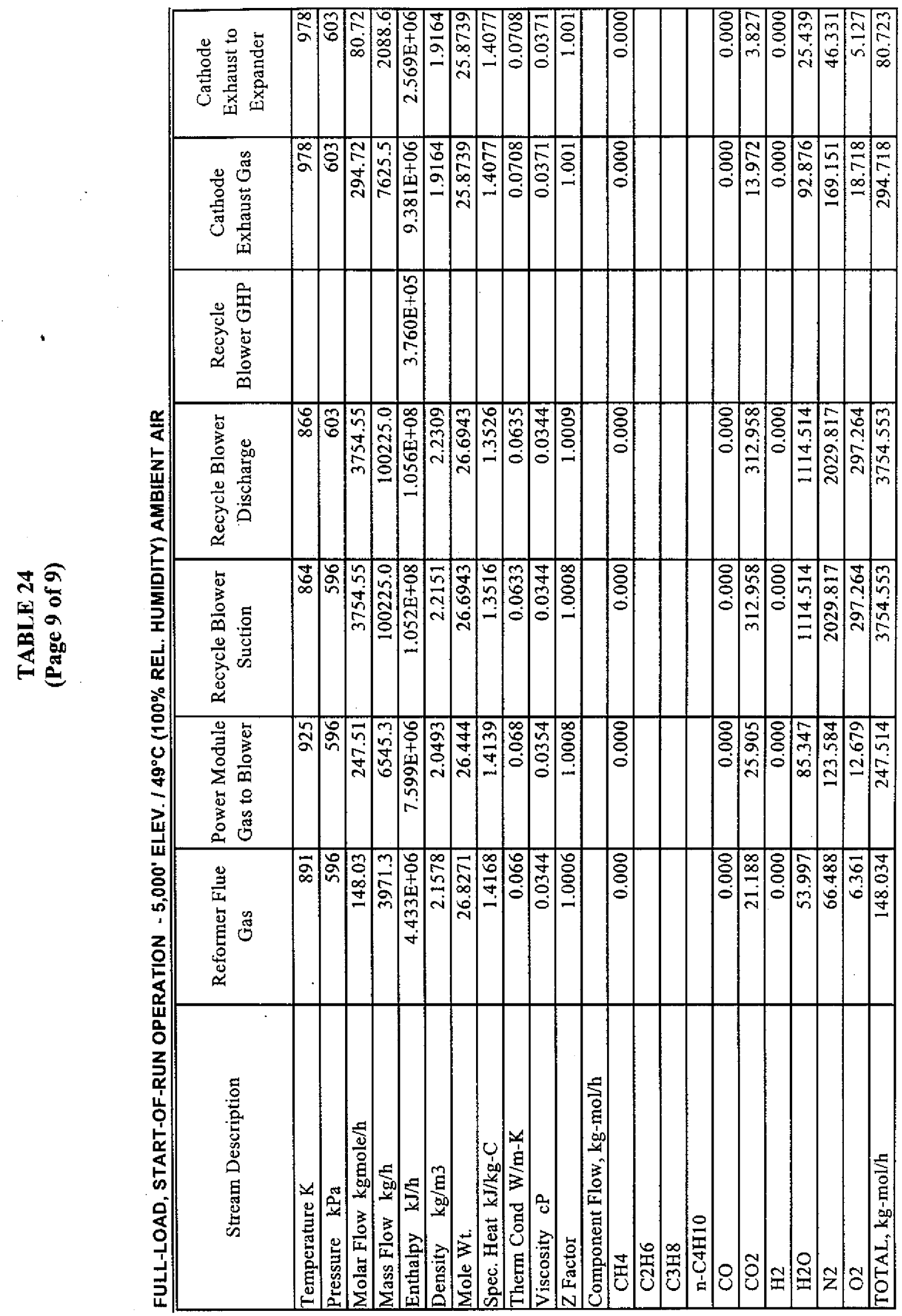




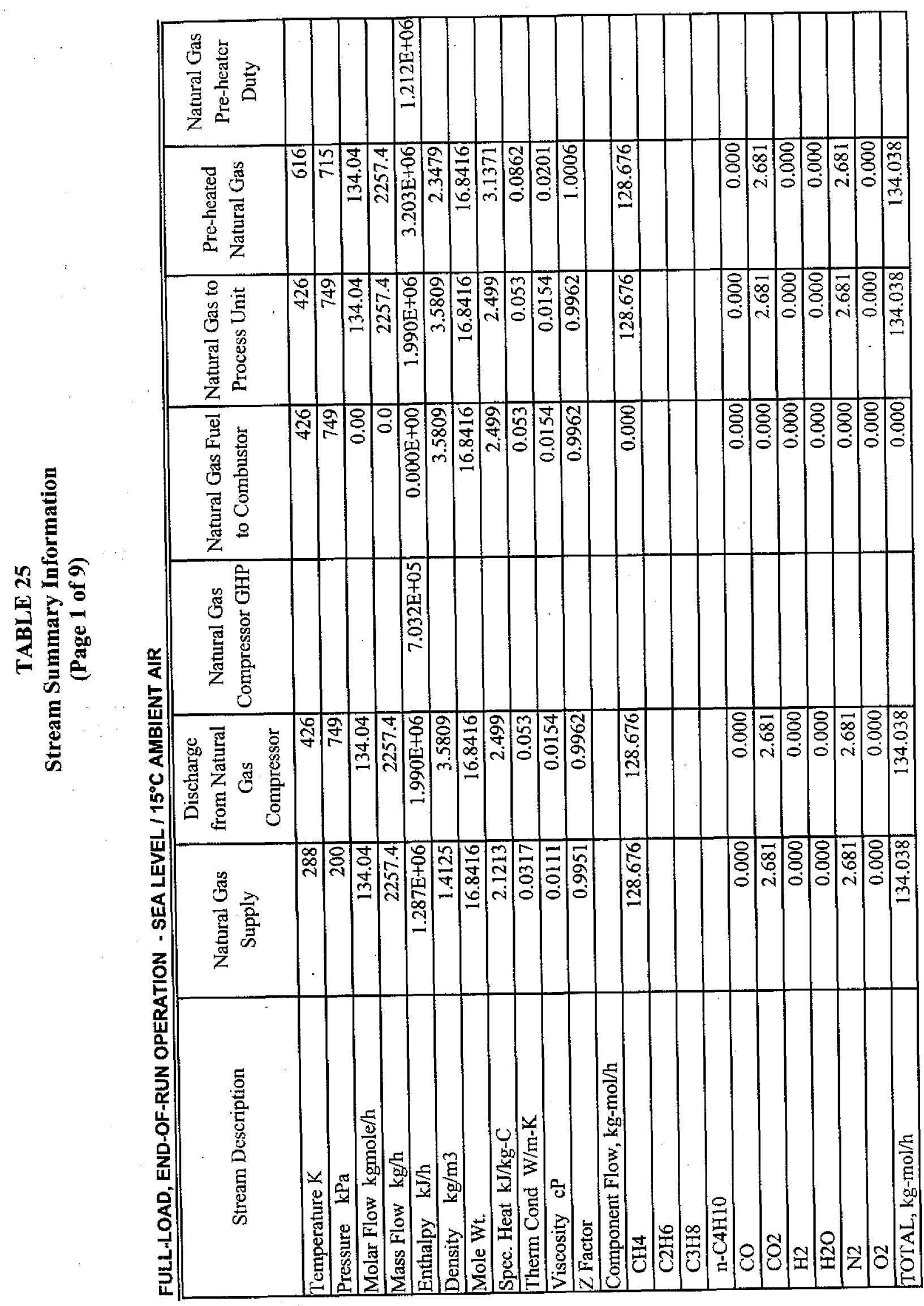

2
a
n. 


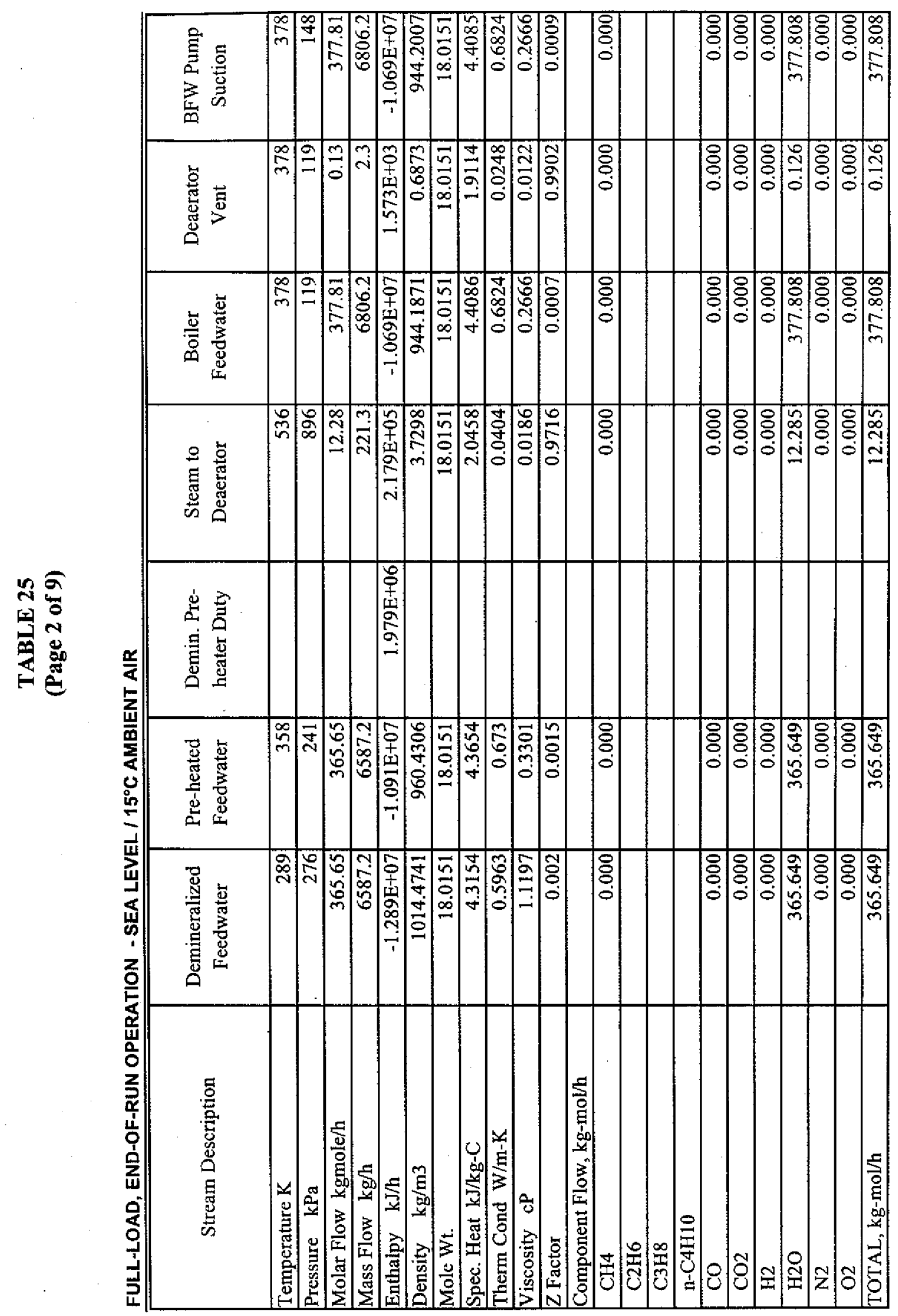




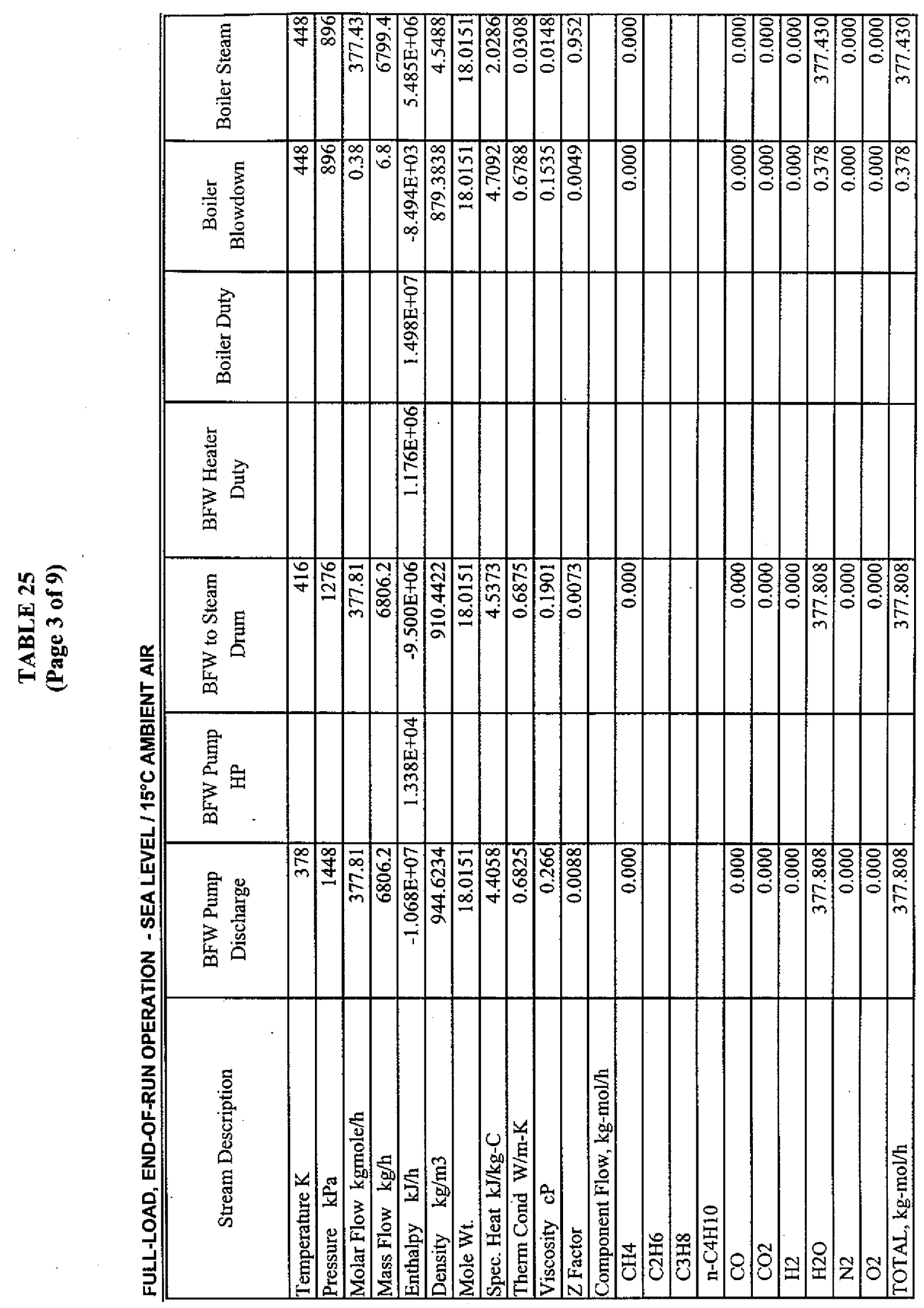




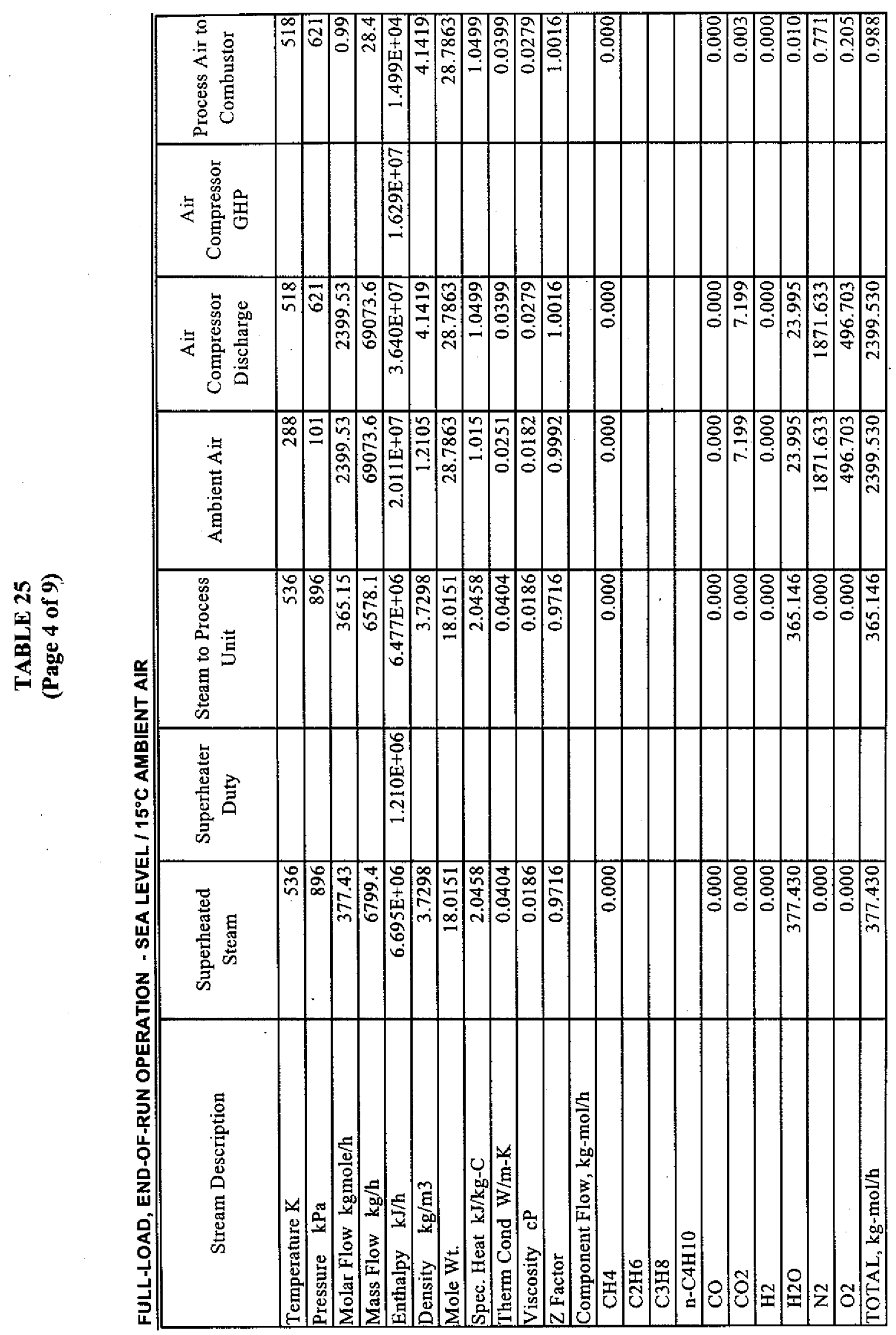




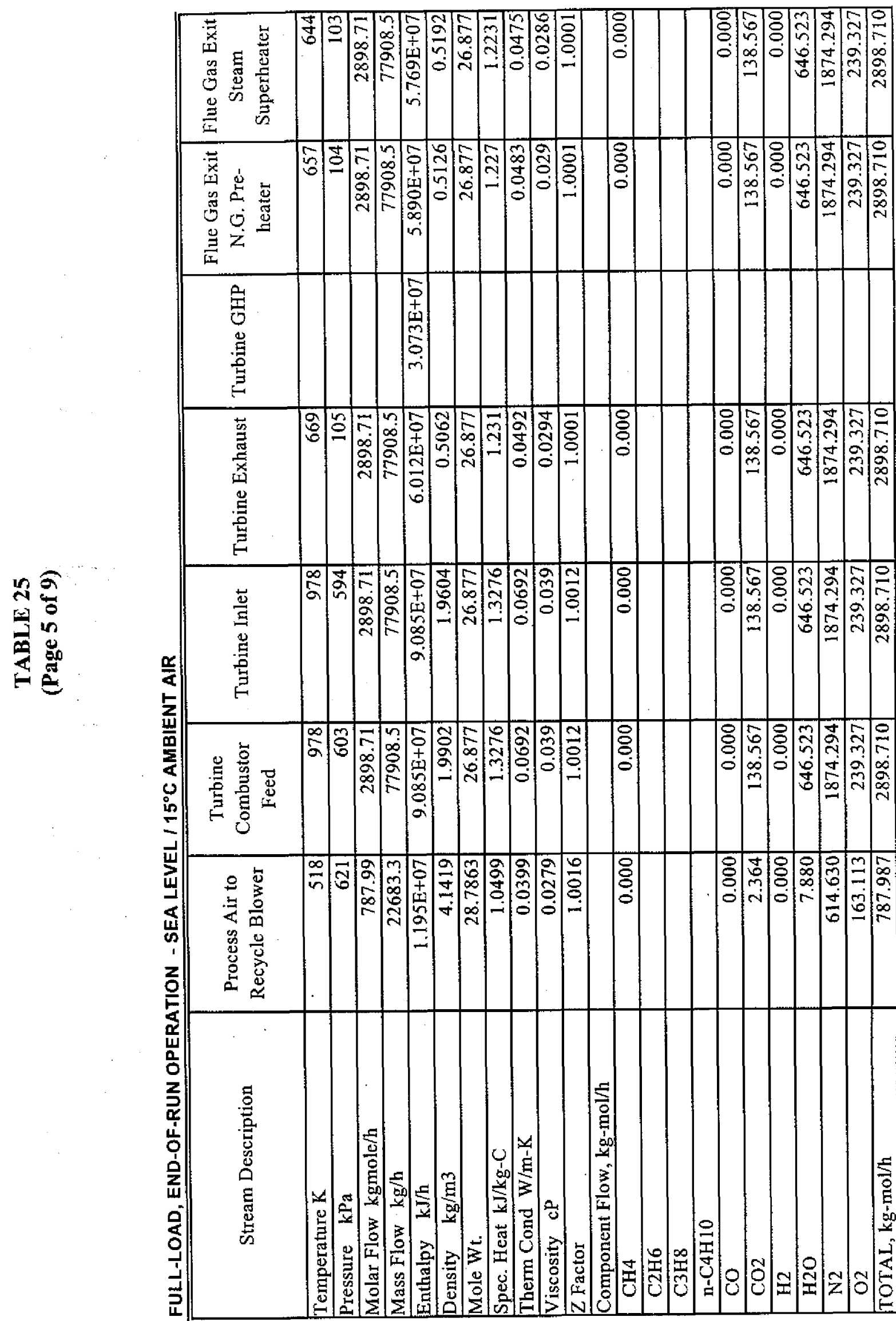

$\frac{9}{6}$ 


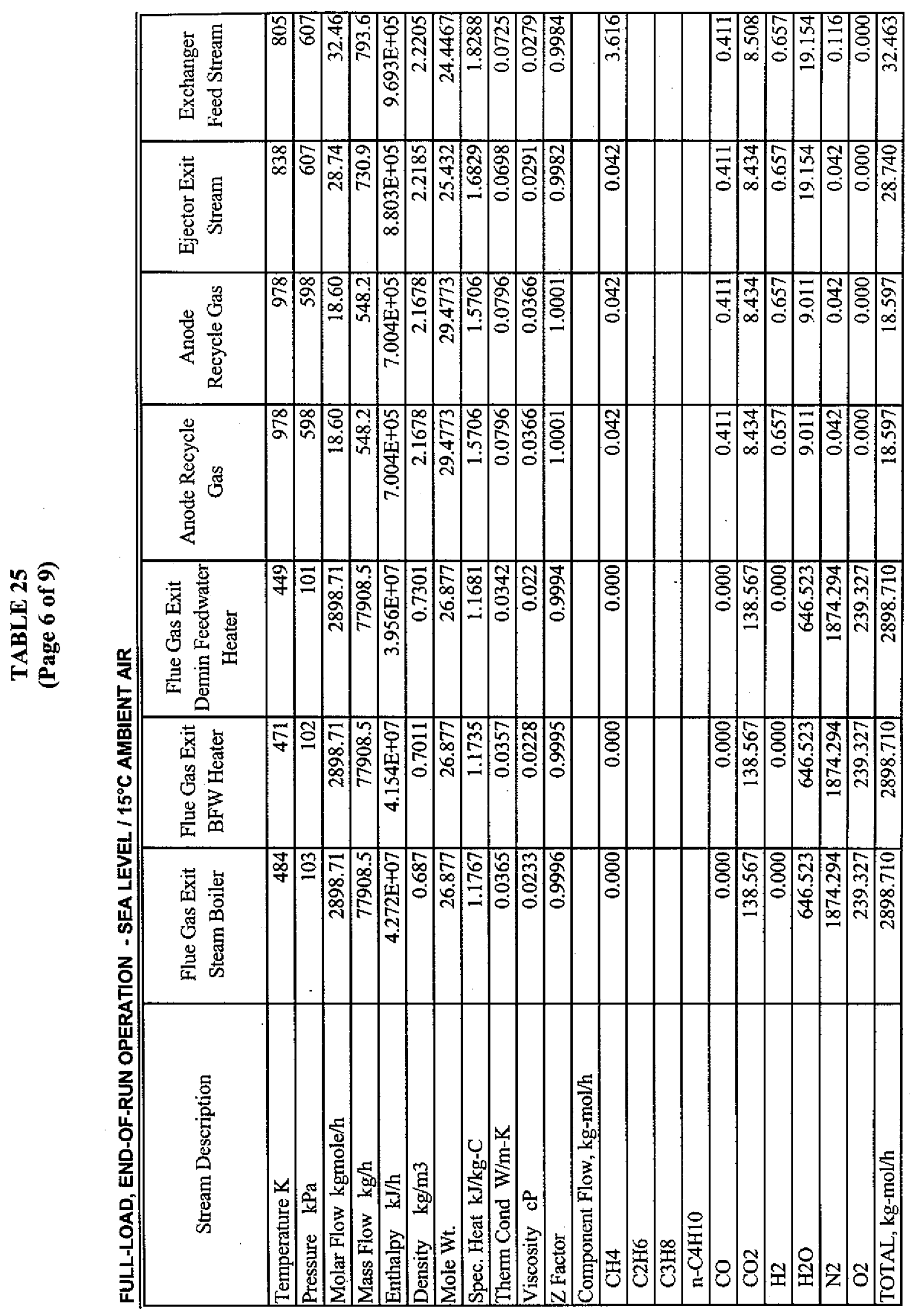




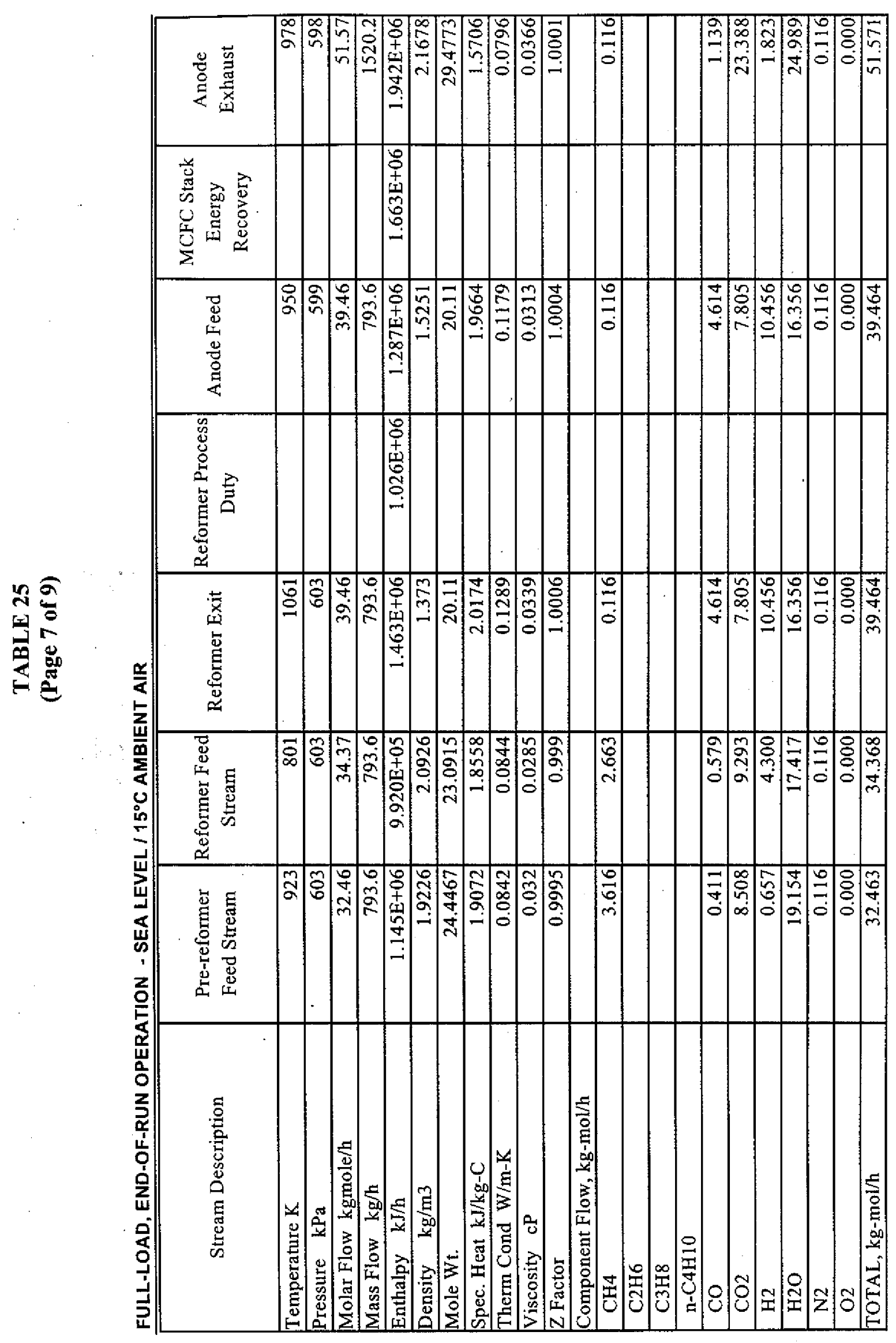




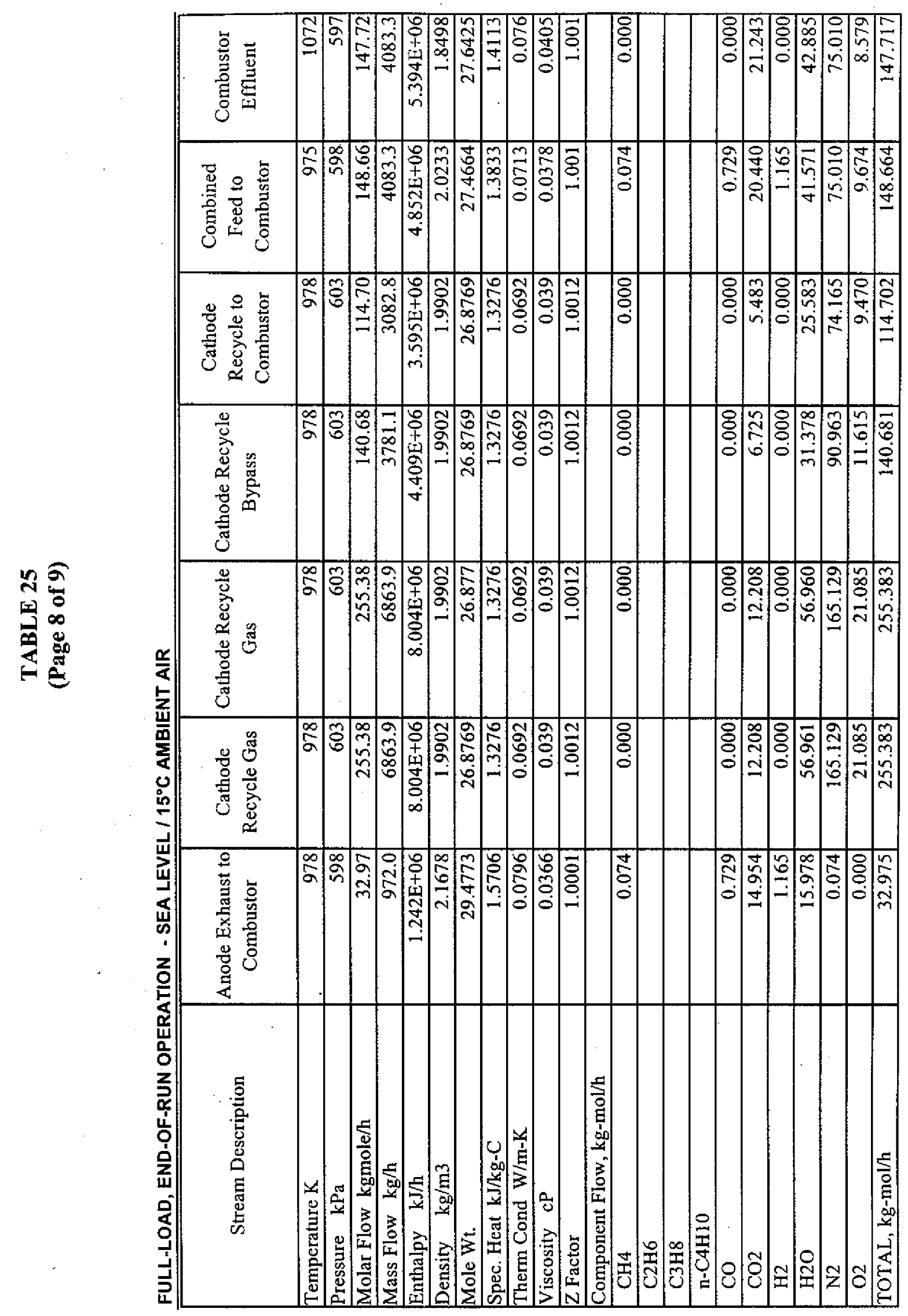




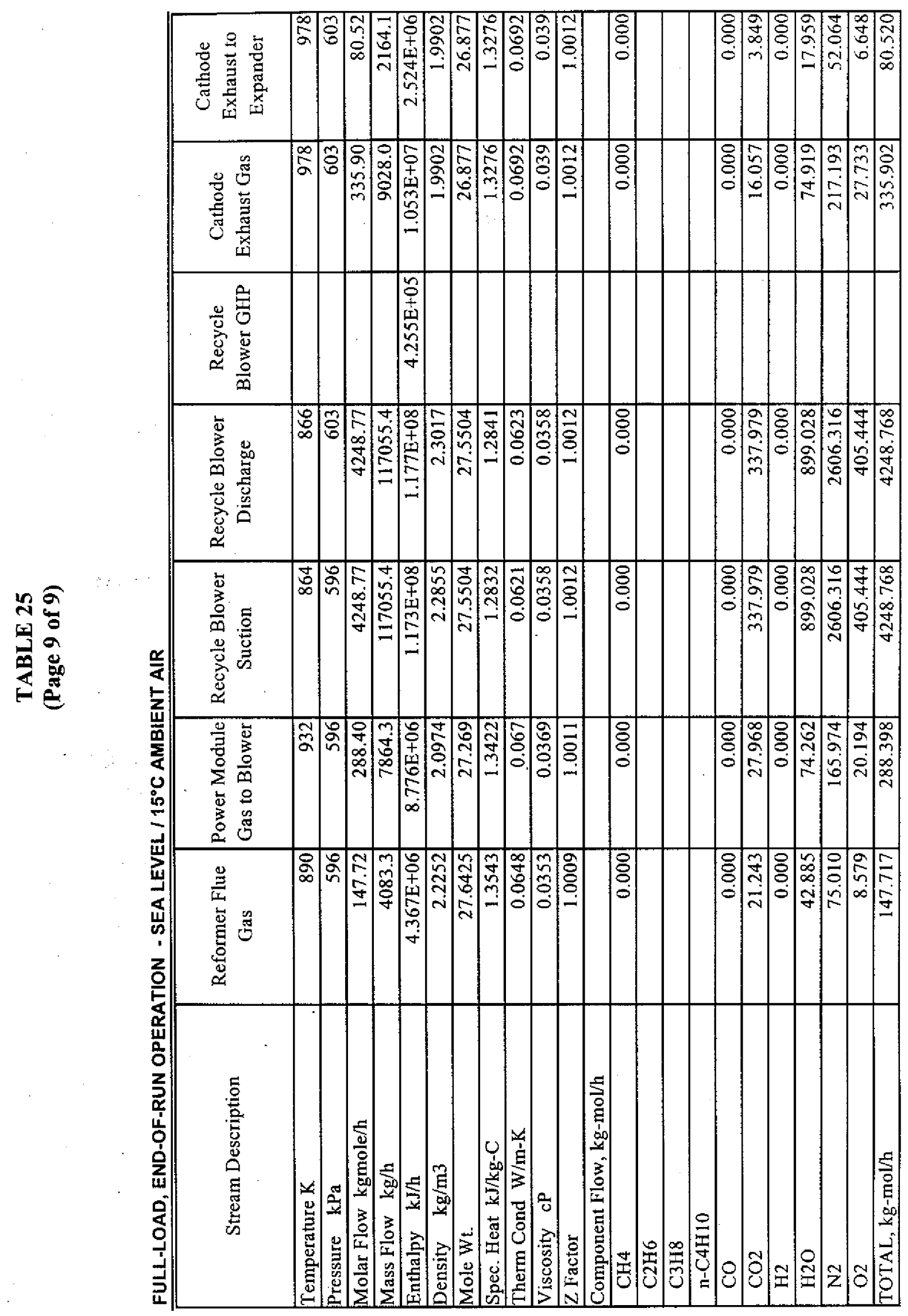




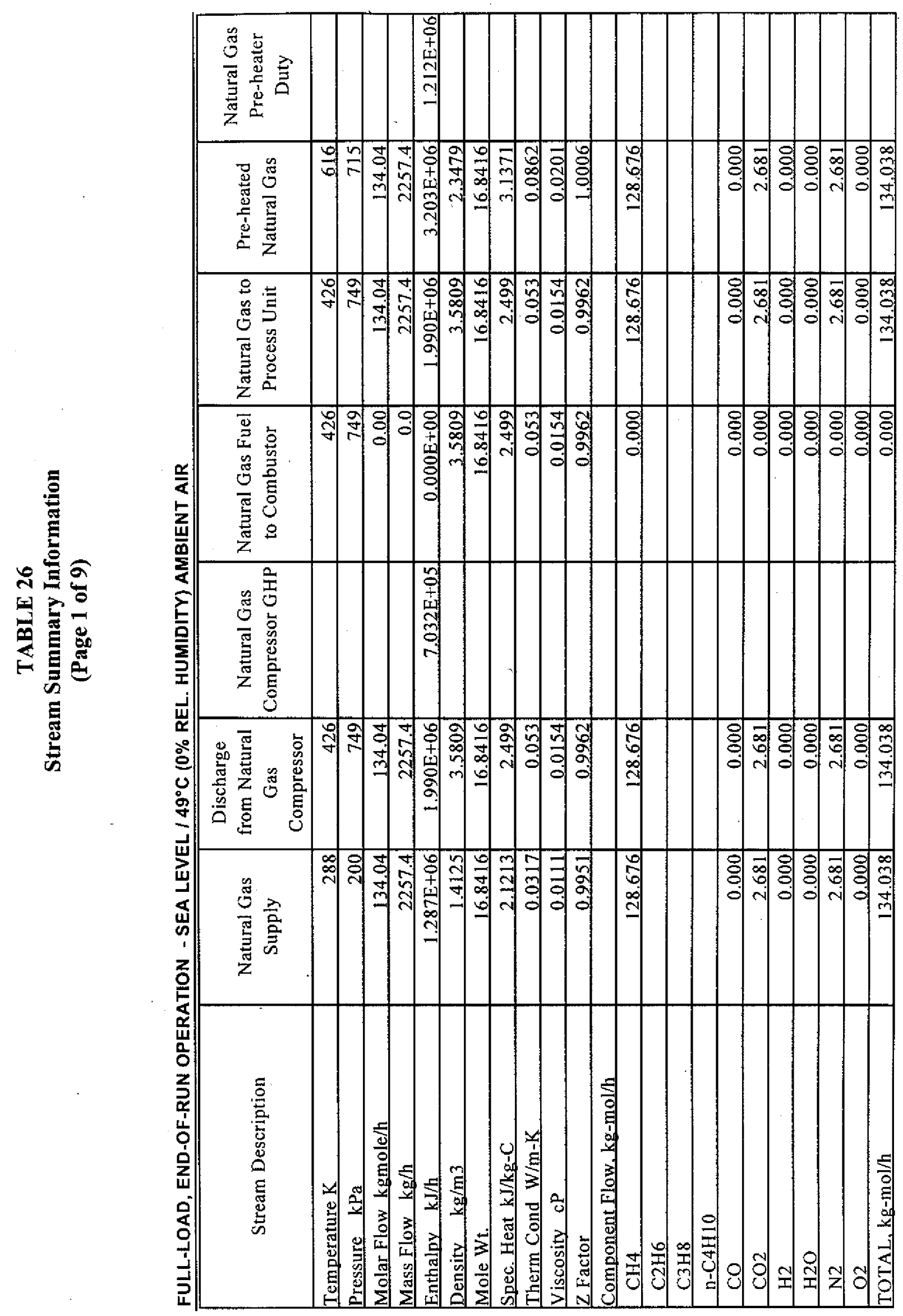




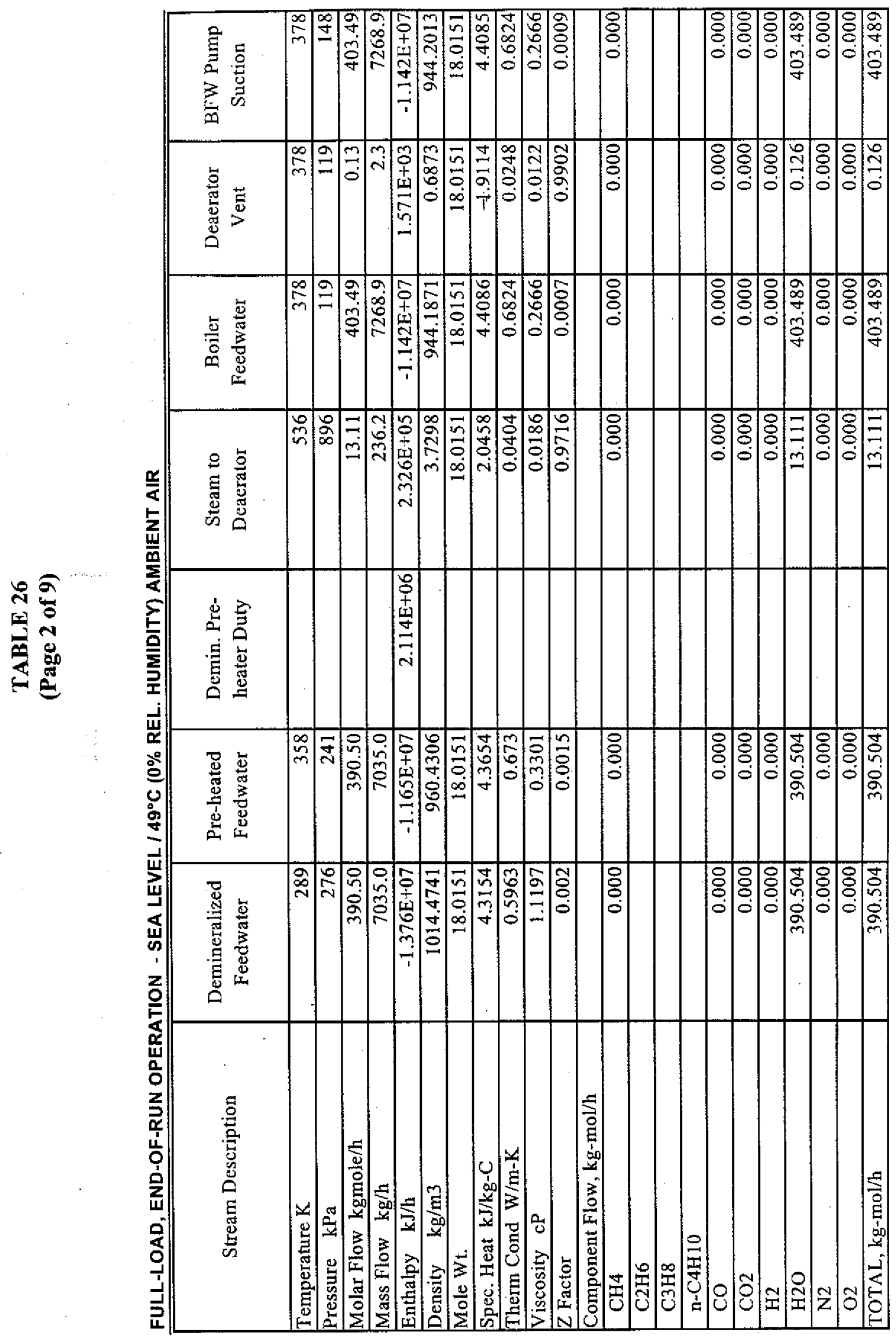

$\frac{8}{\frac{1}{n}}$ 


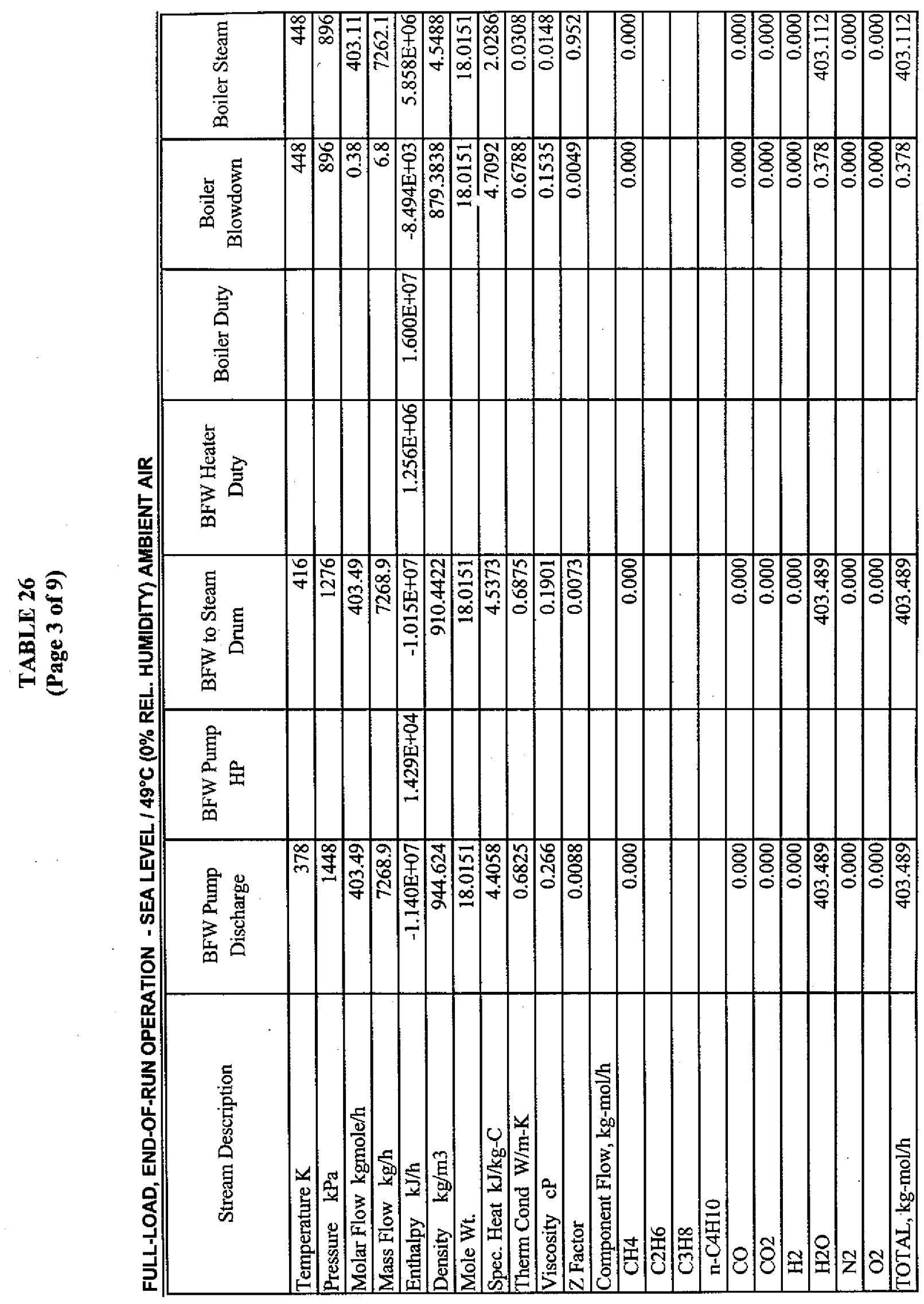




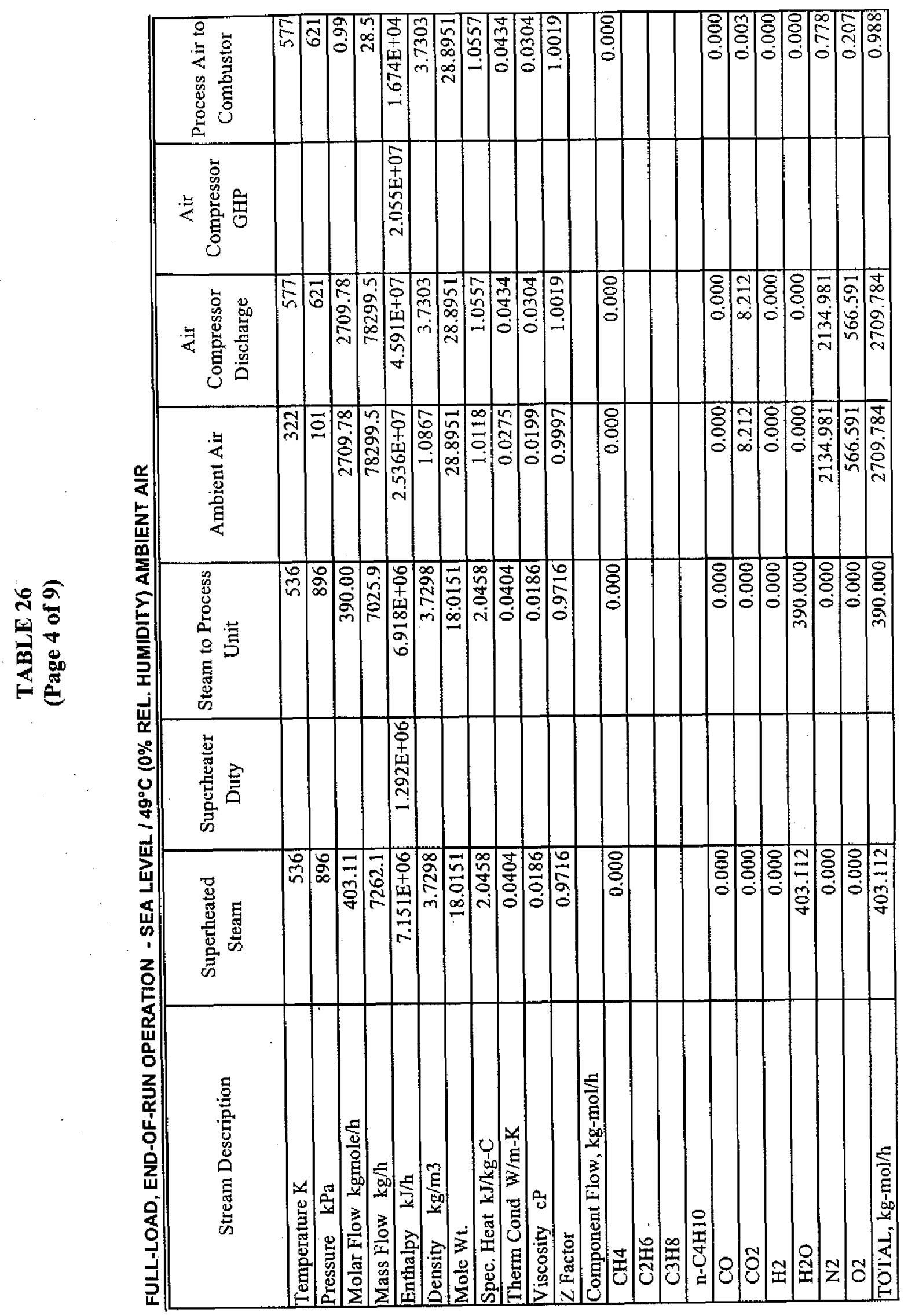




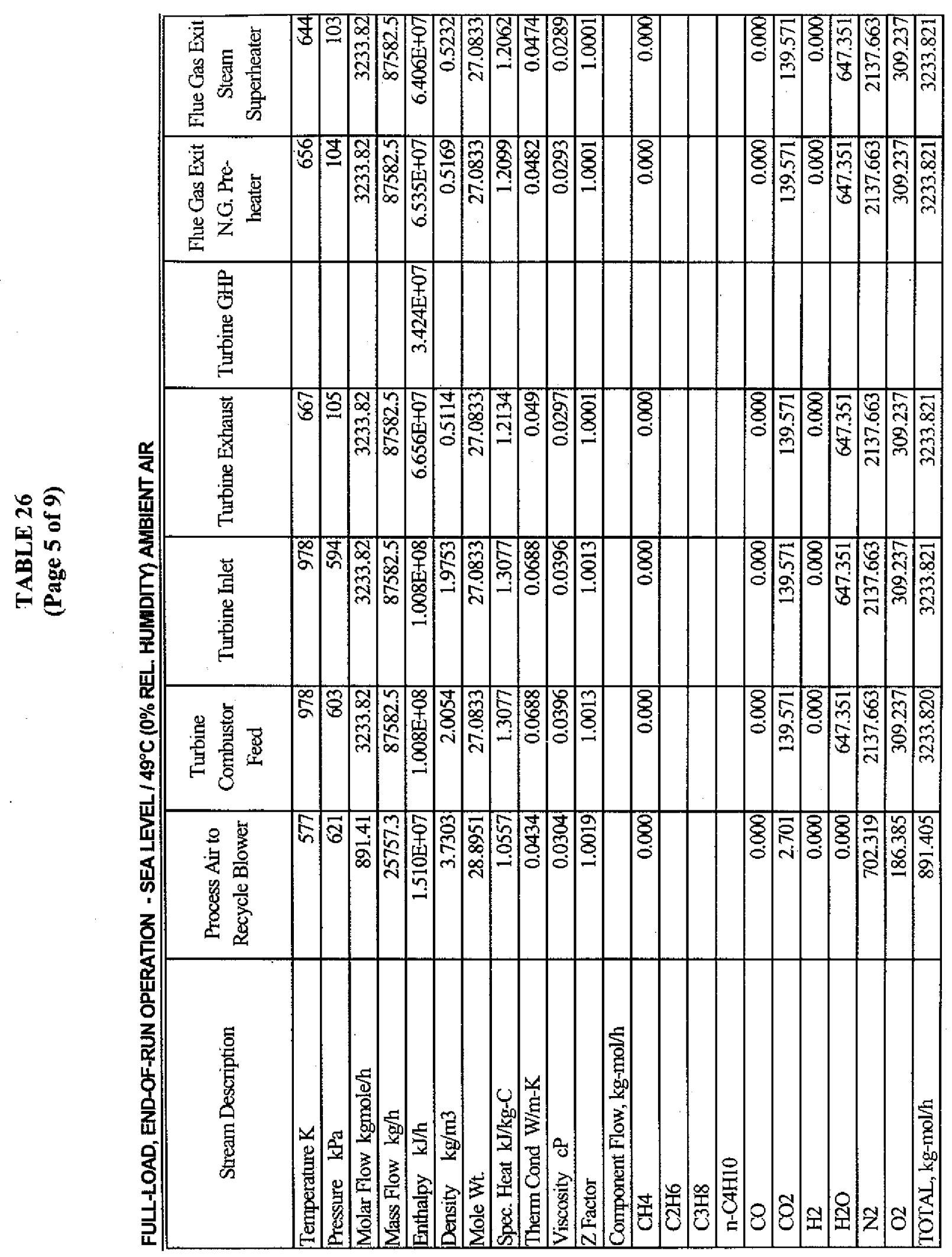

$\frac{a}{\exists}$ 


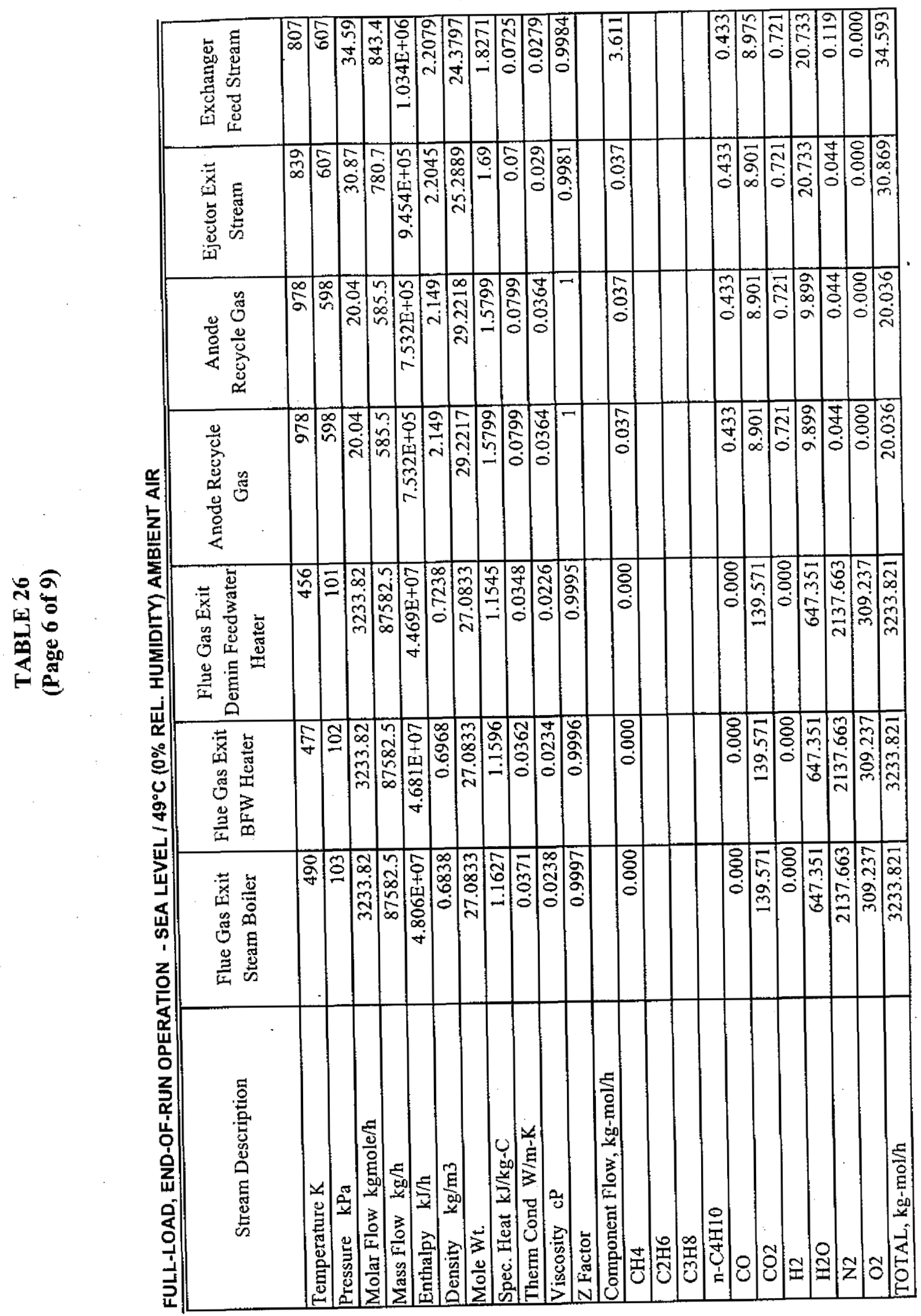




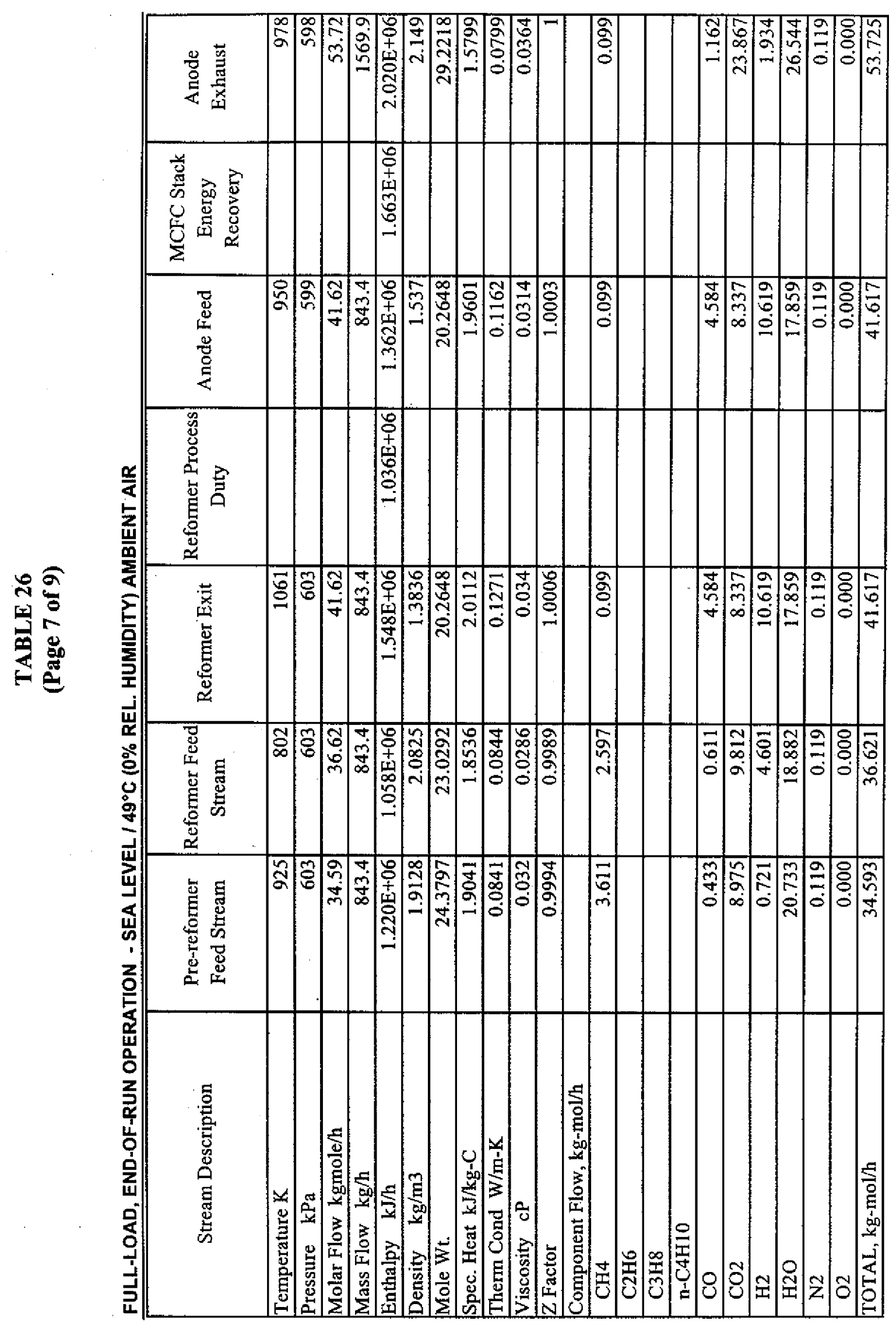




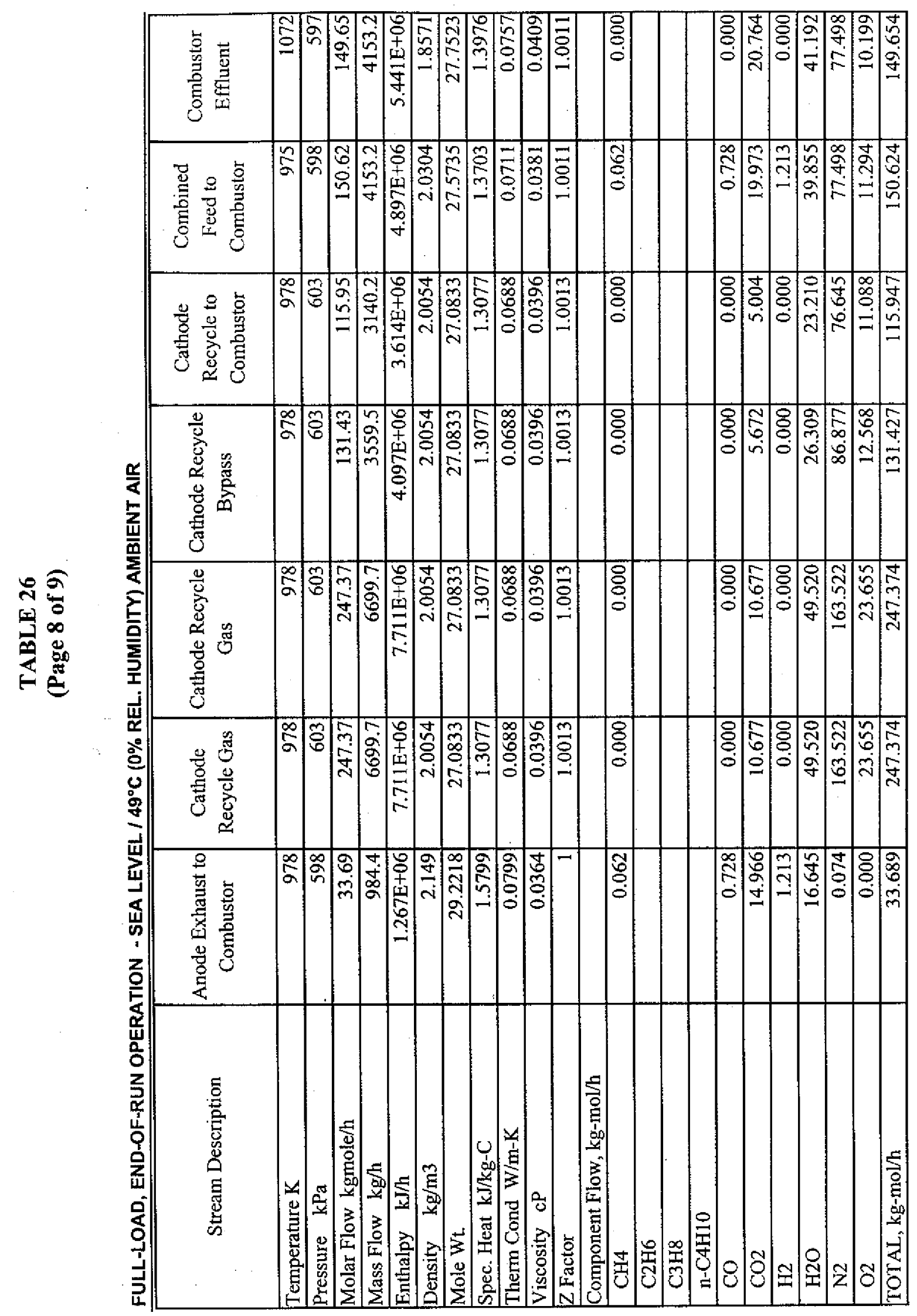




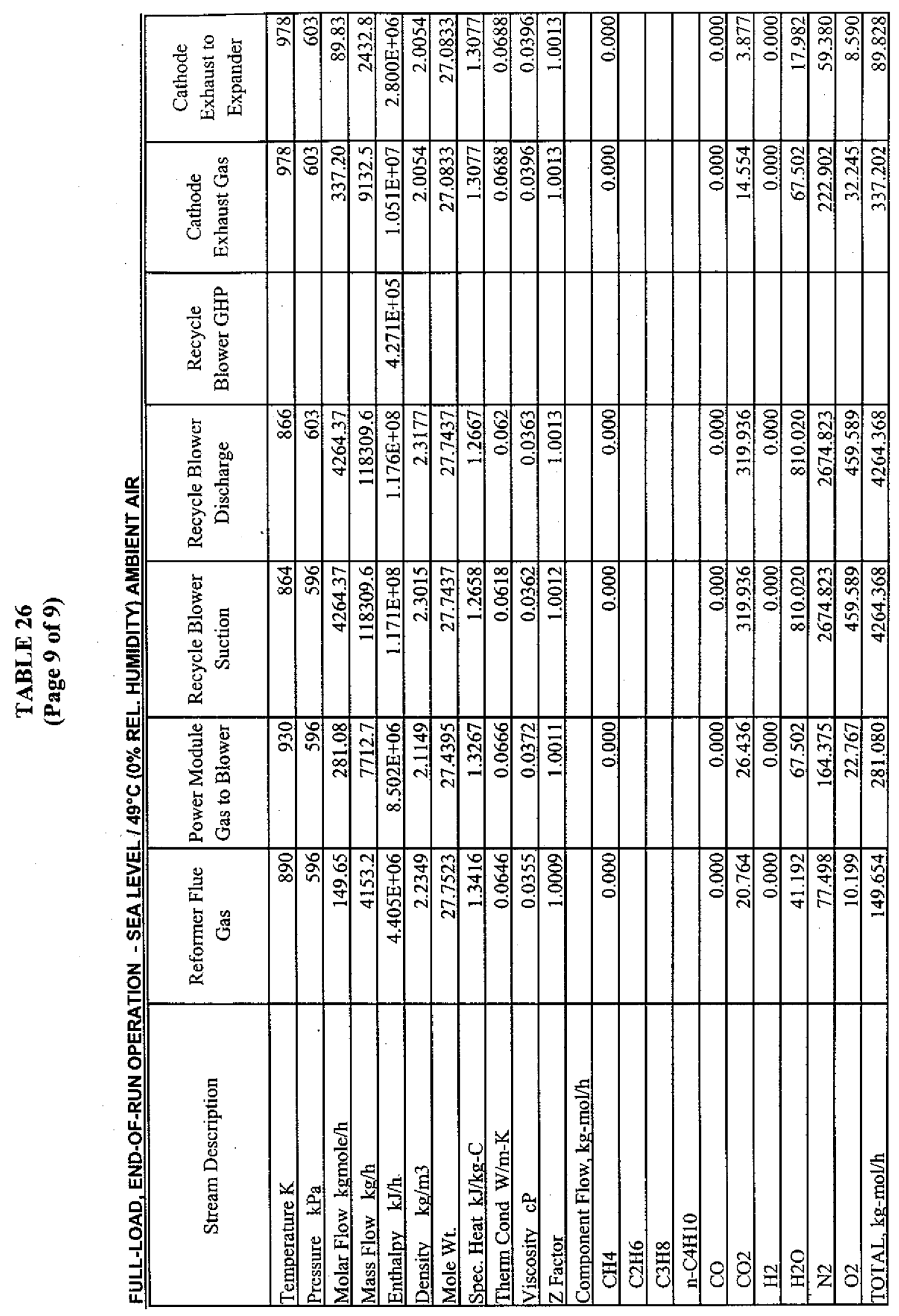

$\frac{\square}{m}$ 


\section{B.4. Control Concept}

\section{B.4.a Fuel Cell}

\section{Fuel Cell Stack Temperature Control}

The primary temperature control of the fuel cell stack is by adjustment of the balance of plant process controls based upon the outlet temperature of the stack's cathode effluent gas flow. These process control adjustments are the regulation of the amount of natural gas introduced to the plant's fuel cell system to maintain the reformer combustor outlet temperature; regulation of the flow of compressed air introduced upstream of the cathode inlet; and the total recycle gas flow rate through the cathode of the fuel cell stack.

Air from the turbine is mixed with the reformer combustor effluent and is supplied to the inlet of the cathode recycle blower. The cathode recycle blower outlet provides the required cooling gas flow to the cathode inlet of the stack. The total flow supplied to the cathode side of the stack is set to meet the excess air required based upon the natural gas flow rate and the cooling flow demanded for cooling as determined by the cathode effluent temperature.

The anode inlet temperature is controlled by varying the natural gas flow bypassed around the reformer feed/effluent heat exchanger. The anode inlet temperature is monitored to ascertain that the proper amount of anode recycle is used to maintain a safe margin above the critical Boudovard carbon formation temperature.

\section{Stack Clamping}

A stack clamping system is required to maintain the correct clamping force on the fuel cell stack. The clamping system consists of a set of springs initially set at the factory and periodically adjusted during plant outages.

\section{Reformer/Fuel Cell Containment Vessel Purge Gas Control}

Purge air is used to prevent accumulation of combustible gas mixtures in the reformer/fuel cell containment vessel. The purge air is designed to continuously sweep through the containment vessel to the reformer combustor. The vessel pressure is controlled to be lower than the process fuel streams for the reformer and fuel cell systems. The flow rate of the purge air is adjusted based upon vessel effluent temperature or $\mathrm{O}_{2}$ and $\mathrm{CO}_{2}$ concentrations.

\section{Fuel Cell Stack Output Current Control}

The inverter used in the plant design will control the current draw from the stack based upon operating stack voltage. The current draw control limits will be based upon the maximum and minimum design limits of the plant. This approach allows stack operation based upon the actual realized stack performance at the most efficient stack operating point. Compensation and adjustment of the plant controls for the slow decline in stack performance, or "decay rate", of the 
fuel cell stack are based upon the fuel gas flow controls following the operating current of the stack over time and providing an automatic unmanned response. In addition, the heat provided from the stack due to internal losses to the balance of plant is held constant with this control concept for improvements in thermal integration and minimizing the required turndown ratios and inherent inefficiencies of the various pieces of balance of plant equipment. 


\section{B.4.b Turbine Generator}

The information contained below is conceptual in nature and subject to change with further HEFPP design and development work. The Rolls- Royce Allison gas turbine generator will be controlled by a programmable logic control system. The gas turbine generator programmable logic control system (PLC) will be interconnected by Ethernet to the plant distributed control system (DCS) for monitoring purposes only. All safety related interlocks such as start/stop/trip and combustor management system will be hardwired between the PLC and the DCS to avoid the potential signal delays associated with digital networks.

\section{Operating Modes}

The gas turbine generator is capable of operating in either island mode or electric grid connected mode on the PLC system. The signal to change from one mode to another will come from the DCS via a hardwired signal based on the position of the plant-to-electric-grid circuit breaker.

The gas turbine generator controls will allow the turbine generator to operate in standalone mode where natural gas is in the combustor (normally in plant startup conditions) or in fuel cell support mode where the fuel cell exhaust is used to drive the gas turbine and no gas is used in the combustor (normal operation).

\section{Compressor Control}

Compressor discharge pressure and volumetric flow rate are controlled primarily by the speed of the compressor section when in the fuel cell support mode. Since the turbine, compressor and alternator are on the same shaft and the turbine section removes thermal energy from the fuel cell, the alternator load will be used as the primary control mechanism for speed control of the turbine generator. The alternator load will be controlled through the power conditioner. The signal to raise or lower the compressor flow or pressure will be sent to the PLC from the DCS. The PLC will convert this signal into a corresponding target load signal, which is sent onto the power conditioner to change the generator load. If due to process conditions, the compressor is close to the surge line and load cannot be changed to avoid the surge, a compressor emergency surge protection control valve will receive a signal to open from the PLC, which will relieve the air pressure to atmosphere. Compressor mass flow and pressure instrumentation signals are fed into the PLC to monitor the compressor surge potential.

A compressor bypass flow control valve is also provided, which connects the compressor and turbine sections. During all modes of operation, the compressor bypass flow control valve is under the supervision of the PLC control system which receives the same input signals from the compressor mass flow and pressure instrumentation mentioned above. In the standalone mode, the compressor bypass flow control valve will be fully open. In the fuel cell support mode, the compressor bypass flow control valve will be fully closed. In any mode, if the turbine generator PLC determines that the compressor is approaching surge with a pre-selected offset, then the compressor bypass flow control valve will modulate to avoid the surge so safe operation can be maintained. 


\section{Overspeed Protection}

The primary mode of controlling the turbine generator speed is with the generator load. The generator load will be controlled by the PLC through the turbine generator power conditioning system. Signals to raise or lower the speed will come from the plant DCS and go to the PLC. To prevent turbine generator overspeed from fuel cell depressurization, a waste gate valve will be provided to bypasses the turbine section. The waste gate valve will fully open on detection of an overspeed condition. This valve is an open/close type of control valve.

\section{Frequency and Voltage Control}

When connected to the electric utility grid, the electric utility controls the plant AC power frequency of the plant. However, the turbine generator power conditioner will have an acceptable operating range of 59.5 to $60.5 \mathrm{~Hz}$. When the frequency of the electric utility grid falls outside the operating range, the power conditioner will send a signal to the electric utility point of common coupling (typically a circuit breaker) to open and disconnect from the electric grid. Should utility disturbance cause the circuit breaker to open and then be restored to acceptable frequency limits quickly, the turbine generator power conditioner will wait for grid voltage and frequency to be within acceptable limits for 5 minutes prior to giving signal to close the breaker for reconnection to the grid. During the 5 minute wait period frequency and voltage will be adjusted to match the electric grid. When operating in island mode (i.e. disconnected from the utility), the turbine generator power conditioner will act as the master controller for frequency with the fuel cell inverters (as slaves) paralleling the turbine generator power conditioner frequency. The PLC will be preprogrammed to control the power conditioner for a $60 \mathrm{~Hz}$ frequency for islanded operation. Throughout the islanded operation period, the utility electric grid frequency will be monitored by the plant DCS and the PLC/power conditioner. When reconnection with the electric grid is desired, the operator will send a signal through the DCS to the PLC to synchronize back with the electric grid. The plant frequency will be adjusted by the turbine generator power conditioner to match the electric grid frequency for interconnection to the electric grid. When the frequencies are matched, the utility to plant circuit breaker will be closed.

The power conditioner will see the alternator input frequency vary up to $275 \mathrm{~Hz}$ with the variable speed gas turbine driver. The power conditioner will rectify the alternator input power to $\mathrm{DC}$ power and then invert the $\mathrm{DC}$ power back to usable $\mathrm{AC}$ power at the proper frequency and minimizing any harmonics.

When connected to the grid, the utility will determine the voltage the plant will see as the power conditioner would be considered a current source. The utility voltage will be matched with the power conditioner output voltage by the power conditioner controls and the available current would be delivered to the power plant auxiliaries with the excess going to the electric grid. If voltage falls outside the operating range of 3744 to 4576 Volts, the power conditioner will send a signal to the utility to plant circuit breaker to disconnect.

In the islanded operating mode, the power conditioner will maintain the plant voltage at a nominal 4160 Volts dependent on the auxiliary load of the plant. The acceptable operating output 
voltage range of the power conditioner will be 3744 to 4576 Volts. If the voltage falls outside the operating range, the power conditioner will trip the plant.

\section{Power Factor Control}

The power conditioner will have the ability to change the power factor within the operating range of 0.85 lag to lead when output is 10 percent or greater. The power conditioner will control the phase angle of the output current with respect to the line voltage. The power conditioner may have an optional power factor control capability which allows the operator, via the DCS and PLC, the capability to set a constant power factor or constant reactive power delivery: 


\section{B.4.c Overall Plant}

In terms of hierarchy, the control system's primary function is to support the operation of the stack: - delivery of fuel and oxidant streams and the removal of waste heat.

The HEFPP is a base-load facility. For base-load power demand from the grid, a Distributed Control System (DCS) based plant control system controls the load by maintaining the required average current density for each MCFC stack in the network and by controlling the speed and power output of the turbine generator. For a particular current draw, or MCFC fuel/oxidant conversion from each stack, a particular flow of natural gas is required to maintain the per-pass utilization, at the design anode recycle ratio. Therefore, the stack current draw automatically resets the flow of natural gas fuel to the power module. To avoid oxidation of the anode itself, there must always be sufficient supply of fuel at the three-phase interface when current is being drawn from the stack.

To maintain isothermal conditions in the MCFC stacks at different current draws, the quantity of cathode feed gas is varied in response to the temperature of the cathode exhaust gas. Cathode feed gas temperature is controlled (above its minimum value) by the injection of cooling air from the compressor into the recycle blower suction.

Steam flow to the fuel processor is set on flow control. The steam supply pressure is maintained by a trim steam condenser and a steam vent, in the event of unplanned shutdowns.

Anode recycle flow is set by the steam flow to the ejector.

The steam reformer outlet temperature is controlled by adjusting the flows of heating gas from the reformer combustor and cathode recycle; a bypass arrangement. The temperature of the heating gas is controlled by trim air injection to the combustor's mixed feed stream. Air is supplied from the compressor.

Air for stack cooling, for combustor temperature control, and for power module vessel purging are all set by demand signals from within the power module. If the total air flow drops below the compressor's minimum flow, then turbine control system can increase compressor throughput by several different mechanisms.

System operating pressure is normally maintained by flow regulation at the turbine inlet; through nozzle opening, or through a throttle valve. 
3.B.5. List of Major Equipment

\begin{tabular}{|c|c|c|c|c|c|}
\hline ITEM \# & MAJOR EQUIPMENT ITEM & $\begin{array}{c}\text { No. } \\
\text { UNITS }\end{array}$ & UNIT CAPACITY & $\begin{array}{l}\text { MATERIAL OF } \\
\text { CONSTRUCTION }\end{array}$ & DESIGN CHARACTERISTICS (if available) \\
\hline$C-200$ & Steam Drum & I & $\begin{array}{l}\text { Separation of } 6,124 \mathrm{~kg} / \mathrm{h} \text { of sal'd } \\
\text { steam from BFW. } \\
\text { Opesating conditions: } \\
896 \mathrm{kPa}, 449 \mathrm{~K}\end{array}$ & Carbon Steel & $\begin{array}{l}\text { Elevated - natural circulation } \\
\text { Design Pressure: } 1.069 \mathrm{kPa}, \\
\text { Design Temperature: } 456 \mathrm{~K}\end{array}$ \\
\hline $\mathrm{C}-20 \mathrm{~L}$ & Deaerator & 1 & $\begin{array}{l}5,933 \mathrm{~kg} / \mathrm{h} \text { of demin. water. } \\
\text { Operating conditions: } \\
119 \mathrm{kPa}, 378 \mathrm{X}\end{array}$ & Carben Steel & $\begin{array}{l}\text { Stean-stripped deatration to }<7 \mathrm{ppb} O 2 \\
\text { Design Pressurc: } 310 \mathrm{kPa} \& \text { Full Vaculth } \\
\text { Design Temperature: } 408 \mathrm{~K}\end{array}$ \\
\hline $\mathrm{C}-202$ & Zinc Oxide Desulfurizer & I & $\begin{array}{l}2,257 \mathrm{~kg} / \mathrm{h} \text { of naturad gas } \\
\text { Operating conditions: } \\
720 \mathrm{kPa}, 616 \mathrm{~K}\end{array}$ & Low-Alloy Steel & $\begin{array}{l}\text { Sulfur reduction from } 4 \mathrm{ppmv} \text { to }<0.1 \mathrm{ppmv} \\
1.50 \mathrm{mID} \times 2.4 \mathrm{~m} \mathrm{T/T} \\
\text { Design Pressure: } 900 \mathrm{kPa} \\
\text { Desiga Temperature: } 680 \mathrm{~K}\end{array}$ \\
\hline E.200A & Natural Gas Pre-heater & 1 & Duty $=1,212,480 \mathrm{~kJ} / \mathrm{h}$ & Low-Alloy Steel & Heat exchange coil in HRSG dust. \\
\hline $\mathrm{E}-2003$ & Stean Supethearer & 1 & Duty $=1,089,840 \mathrm{~kJ} / \mathrm{h}$ & Low-Alloy Sted & Heat exchange coil in HRSO duct \\
\hline E-200C & Steam Boiler & 1 & Duty $=13,489,022 \mathrm{~kJ} / \mathrm{h}$ & Carbon Sicel & Natural circulation boiler in HRSG ducI \\
\hline E-200D & Boiler Feefdwater lleater. & 1 & Duty $=1,058,980 \mathrm{~kJ} / \mathrm{h}$ & Carbon Sieel & Heat exchange coil in HRSG ouct \\
\hline E-200E & Demineralized Water Heater & 1 & Duty $=1,782,940 \mathrm{~kJ} / \mathrm{h}$ & Stainless Steel & Heat exchange coil in HRSG duact \\
\hline $\mathrm{K}-400$ & Natural Gas Compressor & 2 & $\begin{array}{l}3,004 \mathrm{Nm} 3 \mathrm{~h} \text { gas flow } \\
703,236 \mathrm{~kJ} / \mathrm{h} \text { GHP } \\
214 \mathrm{~kW} \text { Motor }\end{array}$ & & $\begin{array}{l}\text { L00\% units - I operating, I standby } \\
\text { Compressor } \mathrm{E}_{\alpha \mathrm{d}} 70 \% \\
\text { Suction conditions: } 200 \mathrm{kPa}, 288 \mathrm{~K} \\
\text { Pressure Ratio } 3.7\end{array}$ \\
\hline R-600 & Gas Turbine/Generator Package & 1 & $3,429 \mathrm{~kW}$ Generator Output & & 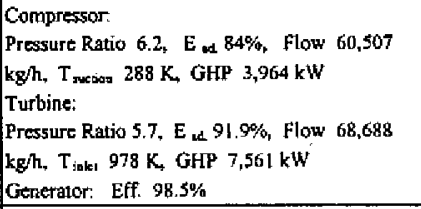 \\
\hline P-600 & Boiler Feedwater Pump & 2 & $\begin{array}{l}6.4 \mathrm{~m}^{3} / \mathrm{h}, 1,300 \mathrm{kPa} \text { differential } \\
\text { head, } 3.9 \mathrm{~kW} \text { Motor }\end{array}$ & $\begin{array}{l}\text { CS Casing. High- } \\
\text { Alioy Impeller }\end{array}$ & $\begin{array}{l}100 \% \text { units - ] operating, I ständby } \\
\text { Multi-stage centrifugal }\end{array}$ \\
\hline
\end{tabular}

\begin{tabular}{|c|c|c|c|c|c|}
\hline ITEM\# & MAJOR EQUIPMENT ITEM & $\begin{array}{l}\text { No, } \\
\text { UNTrS }\end{array}$ & UNIT CAPACITY & $\begin{array}{l}\text { MATERIAL OF } \\
\text { CONSTRUCTION }\end{array}$ & DESIGN CHARACTERISTICS (if avallable) \\
\hline $\mathrm{C}-500$ & Power Modufe Vesset & 9 & $\begin{array}{l}3.1 \mathrm{~m} \mathrm{ID} \times 14.0 \mathrm{~m} \mathrm{T/T} \\
\text { Operatipg conditions: } \\
603 \mathrm{kPa}, 550 \mathrm{~K}\end{array}$ & $\begin{array}{l}\text { Refractory-lined } \\
\text { Carbon Steel }\end{array}$ & 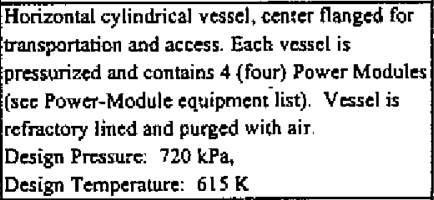 \\
\hline $\mathrm{K}-500$ & Recycle Gas Blower & 3 & $\begin{array}{l}85,949 \mathrm{Nm} 3 / \mathrm{h} \text { gas flow } \\
384,120 \mathrm{~kJ} / \mathrm{h} \text { GHP } \\
117 \mathrm{~kW} \text { Motor }\end{array}$ & High-Alloy Steel & $\begin{array}{l}\text { Axial Far/Blower. } \\
\text { Differential head } 6.2 \mathrm{kPa}, \mathrm{E}_{\mathrm{wd}} .75 \% \\
\text { Suction conditions: } 596 \mathrm{kPa}, 864 \mathrm{~K}\end{array}$ \\
\hline
\end{tabular}

\begin{tabular}{|c|c|c|c|c|c|}
\hline ITEM \# & MAJOR EQUIPMENT ITEM & $\begin{array}{l}\text { No. } \\
\text { UNITS }\end{array}$ & UNIT CAPACITY & \begin{tabular}{|l|} 
MATERIAL OF \\
CONSTRUCTION \\
\end{tabular} & DESIGN CHARACTERISTICS (if avalable) \\
\hline E-501 & Reformer Feed/Effluent Exchanger & 36 & Duty $=160,564 \mathrm{~kJ} / \mathrm{h}$ & High-Atloy Steel & $\begin{array}{l}\text { Operating differentiaj pressure: < } 10 \mathrm{kPa} \text { (hot } \\
\text { side to cold side, inside to outside) } \\
\text { Design Pressure: } 100 \mathrm{kPa} \\
\text { Design Temperature: } 1070 \mathrm{~K}\end{array}$ \\
\hline K-501 & Anode Recycle Gas Ejector & 36 & $\begin{array}{l}\text { Steam: } 164.6 \mathrm{~kg} / \mathrm{h} \\
(872 \mathrm{kPa}, 536 \mathrm{~K}) \\
\text { Ancoie recjcle: } 493.7 \mathrm{~kg} / \mathrm{h} \\
(604 \mathrm{kPa}, 978 \mathrm{~K}) \\
\text { Pressure ratio }=1.01 \\
\text { Weight ratio }=3.0 \\
\end{array}$ & High-Alloy Steel & $\begin{array}{l}\text { Operating differential pressure: } 280 \mathrm{kPa} \text { (motive } \\
\text { steam section) } \\
\text { Design Pressure: } 500 \mathrm{kPa} \text {, } \\
\text { Design Temperature: } 980 \mathrm{~K}\end{array}$ \\
\hline P-501 & Power Conversion System - Inventer & 9 & $\begin{array}{l}2,180 \text { amps, } 800-900 \mathrm{~V} \mathrm{DC} \\
1968 \mathrm{~kW} \text { input. }\end{array}$ & & $\begin{array}{l}4160 \text { VAC, } 3 \text { phase, } 60 \mathrm{~Hz} \text { output }-1918 \mathrm{~kW} \\
\text { Efficiency } 97.5 \%\end{array}$ \\
\hline R-501A & Pre-seformer & 36 & $\begin{array}{l}721 \mathrm{~kg} / \mathrm{h} \text { feed gas } \\
24 \% \mathrm{CH}, \text { conversion }\end{array}$ & Stainless Steel & $\begin{array}{l}\text { Adiabatic catalytic reactor - cylindrical packed } \\
\text { bed }\end{array}$ \\
\hline R.SOLB & Reformer & 36 & $\begin{array}{l}721 \mathrm{~kg} / \mathrm{h} \text { feed gas } \\
73.6 \% \mathrm{CH}, \text { conversion } \\
\text { Duty }=1,018,806 \mathrm{~kJ} / \mathrm{h}\end{array}$ & Stainless Steel & $\begin{array}{l}\text { Horizontaily-stacked, plate-type catalytic reactor } \\
\text { Design Temperature: }\end{array}$ \\
\hline $\mathrm{R}-501 \mathrm{C}$ & MCFC Stack & 36 & 492 kW DC output & & $\begin{array}{l}\text { Molten-carbonate Fuel Ceil } \\
758 \mathrm{mV}, 200 \mathrm{~mA} / \mathrm{cm}^{2} \\
300 \text { ptares, } 10,900 \mathrm{~cm}{ }^{2} / \mathrm{plate}\end{array}$ \\
\hline \multirow[t]{2}{*}{ R.50ID } & Reformer Comburtor & 36 & $\begin{array}{l}4,096 \mathrm{~kg} / \mathrm{t} \text { feed gas } \\
1,072 \mathrm{~K} \text { exit 1emperature }\end{array}$ & High-Alloy Steel & $\begin{array}{l}\text { Catalytic Combustor - combustion of residual } \\
\mathrm{H} 2, \mathrm{CO} \text {, and } \mathrm{CH} 4 \text { in anode exhaust gas } \\
\text { Design Temperalure: }\end{array}$ \\
\hline & Stepup Transformer & 1 & $\begin{array}{l}\text { 2SMVA OFA } \\
4160 \text { V input } \\
138 K V \text { output } \\
\end{array}$ & Carbon Steel & Depends on utility requirement? \\
\hline
\end{tabular}


3.C. ECONOMIC PROJECTIONS 


\section{C Economic Projections}

\section{C.1. Description of Estimate}

The three most common techniques used for plant cost estimates are: - curve estimates, factored estimates, and definitive estimates.

A curve estimate relies on a historical relationship between plant capacity and cost for a particular technology. There is no historical database available yet for commercial MCFC power plants. Therefore, a curve-estimated cost is not applicable.

A factored cost estimate relies on empirical cost data collected over time from actual projects. Cost relationships between different system costs (major equipment, bulk materials, direct labor, indirect costs, etc.) are characterized from analysis of the historical data. Factors are assigned to represent the relationship. Once a cost system, say the equipment costs, is well known, the remaining plant costs can be obtained by applying these factors to the known cost items.

Again a historical database, from which factors can be derived, is not available for commercial MCFC power plants.

A definitive estimate requires a significant amount of detailed engineering to be performed (15$25 \%$ ), so that material takeoffs of bulk material quantities can be used to develop accurate costs. A definitive estimate includes known site location, firm design basis, firm equipment quotations, knowledge of local construction labor markets, and a detailed construction plan.

Unfortunately, this study does not provide sufficient time or budget to develop a definitive estimate. In addition, as mentioned above, there is no historical database available to perform a curve or factored estimate. Therefore, in this case, capital costs were developed from vendor quotations and in-house equipment estimates, and installation/construction costs were developed using costs developed for the $450 \mathrm{~kW} \mathrm{MCFC} \mathrm{PDI}{ }^{3}$ unit and applying best engineering judgement.

MC-Power and Rolls-Royce Allison provided costs for the MCFC stacks and the gas turbine, respectively.

The plant construction plan is to maximize shop assembly of equipment, piping and instrumentation as packages or modules, so as to minimize construction time in the field. Module sizes are constrained by permissible shipping dimensions and weights.

Per the design basis, the capital cost estimate is based on mature technologies and integration techniques, not first-of-a-kind systems. Therefore, the assumption is that initial R\&D and engineering expenditures have already been recouped by equipment vendors, and that sales price is based on competition in a mature-technology market.

\footnotetext{
${ }^{3}$ Process Design Improvement program - MC-Power/DOE Contract DE-FC21-95MC30133
} 


\section{C.2. Sources of Cost Data}

Capital cost data for major equipment items were provided from vendor quotes. The fuel processor system costs were provided by IHI. The MCFC stack costs were provided by M-C Power. The gas-turbine generator costs were provided by Rolls-Royce Allison. The inverter costs were provided by Trace Technologies. The recycle blower costs were provided by Robinson Industries, Inc. The HRSG unit costs were provided by the G.C. Broach Company. Other costs were estimated from previous recent projects (with similar equipment) and the 1998 Richardson Process Plant Construction Estimating Standards. 


\section{C.3. Estimate of Capital and Operating Costs}

\section{Capital Costs}

The capital cost estimate is based on the costs for new equipment, such as the fuel cell stacks and the plate reformers, being projected to the cost for he final stages of its evolutionary development, from both a technical standpoint and from a production/assembly standpoint. In addition; it is assumed that the HEFPP has been demonstrated to be commercially competitive (economically and environmentally) to the extent that a significant number of $20 \mathrm{MW}$ units are installed each year.

Equipment vendors provided capital costs for equipment in response to preliminary equipment specification inquiries. The major equipment cost list appears in Table 12. Equipment quotes for the gas turbine generator, HRSG unit and solid-state inverters, etc. were included as received, but modified to include a $10 \%$ cost reduction for volume production, on the assumption that twenty, $20 \mathrm{MW}$ HEFPP plants would be installed domestically, annually. Equipment costs for technologies continuing to undergo evolutionary development, such as the M-C Power MCFC and IHI Fuel Processor, were assumed to follow the standard cost decline curve from "high cost" for initial production, decaying to a "low-cost" plateau for future mass production. MCFC stack and fuel processor mass-production capital costs are projected to be $300 \$ / \mathrm{kW}$ and $145 \$ / \mathrm{kW}$, respectively.

Sales tax on equipment purchases and transportation costs for equipment from the module assembly yard to site are assumed to be $6 \%$ and $5 \%$ of the equipment capital costs, respectively.

Bulk materials (piping, electrical, instrumentation, insulation, etc.) and labor (for equipment and bulk materials installation), subcontracts, and field indirect costs are accounted for under "Installation Costs". Installation costs for the HEFPP were estimated from detailed module fabrication/assembly costs developed for a single $450 \mathrm{~kW}$ module, as part of the PDI program and on typical larger conventional power plant installation costs.

Since it is intended to compare the costs and COE for the HEFPP to those for conventional, commercially-proven technologies, such as combined-cycle gas turbine power generation plants, a process equipment contingency has been applied to those equipment in the HEFPP which are in the development cycle, and whose costs were projected to mature-equipment status - it being quite possible that unforeseen factors will increase the actual mature-equipment costs.

In addition, $15 \%$ of the cost for the process plant and general plant facilities has been applied to the total capital requirement for the HEFPP (and the conventional power generation plants) as a project contingency, to address the likelihood of other project-related cost overruns.

The sum of the major equipment installed costs is the Process Plant Cost (PPC).

General plant facilities accounts for miscellaneous materials, equipment and services needed to support commercial operation of the plant, e.g. fire protection systems, in-plant roads, boundary 
fences, lighting, etc. The cost of these items is estimated to be $5 \%$ of PPC for the HEFPP and the gas turbine combined cycle option.

Home office engineering fees and service costs are estimated to be $7.5 \%$ of PPC with the high degree of plant modularization in both the HEFPP and the combined cycle plants.

Startup costs are assumed to consist of one month of operating labor, one month of maintenance materials, one month of consumables, one week of natural gas fuel, and one half percent of PPC for both types of plants.

Spare parts were assumed to be $1 / 2$ percent of the process plant cost for both HEFPP and combined cycle plants.

Working capital is assumed to consist of three months of operating labor and two months of consumables (excluding natural gas) with a twenty-five percent contingency. Three months of maintenance materials are also included for both plants.

The total capital requirements for the HEFPP are shown in Table 13.

\section{Operating Cost}

Operating costs for the HEFPP are based on a $92 \%$ annual capacity factor and fifty weeks operation per year.

The capacity factor is an estimate, based on similar plant histories, of the percentage of nameplate capacity that a plant will actually achieve during operation. This figure is often less than $100 \%$, due to the plant experiencing unanticipated reductions in power output, and/or unplanned shutdowns.

Two weeks per year is typical of the time period required to do annual plant maintenance.

For the present analysis, the cost of natural gas is fixed at $\$ 3.00 \mathrm{MMBtu}(\mathrm{HHV})$.

The HEFPP plant organization chart is shown in Table 11. Operators will work in 12 hour shifts. O\&M supervisor and water treatment specialist will fill in on vacation/sick leave of operators. The operations and maintenance would be similar to those expected for a combined cycle power plant of similar size on a single power plant site. The combined cycle organization was based on September, 1994 Power Magazine article "Operating and Maintaining IPP Cogen Facilities (pages 13-32).

Maintenance material costs are assumed to be $1 \frac{1}{2} \%$ of $\mathrm{PPC}$ and are primarily consumables. This is a historically based value, and is typical for plants requiring light service demands.

Insurance and local taxes are assumed to be $2 \%$ of PPC. In less populated areas, local property taxes are between $1-2 \%$ of the direct-capital investment. Annual insurance rates typically amount to $1 \%$ of the direct-capital investment. 
Catalysts and chemicals cost include the cost of boiler water treatment chemicals and reforming catalyst replacement. Since the reforming catalyst operates under mild conditions for steam reforming catalysts, its operating life is anticipated to be approximately ten years.

The plant annual operating costs for the HEFPP are shown in Table 14.

\section{COE Analysis}

The cost of electricity (COE) is determined by NPV analysis. The COE is adjusted until the sum of the present-value cash flows, at a $15 \%$ discount rate, over the life of the plant is equal to zero.

The following basis (in addition to items mentioned above) was used for the COE analysis:

- Plant design lifetime

- Capital charge rate

- Inflation allowance

- Additional capital expenditure

- Depreciation

- State \& Federal Taxes
$25 \mathrm{yrs}$

$15 \%$

none - constant dollars

MCFC stack replacement every 5 yrs. Stack salvage value is assumed to be $33 \%$ of the stack equipment cost Double Declining Balance for 10 yrs, straight line remaining life

$43 \%$

Plant revenues are based on power exports for SOR and EOR assuming straight-line decline in stack performance.

The total project capital requirement is assumed to be expended over a two-year period, with one-third of the expenditure occurring in the first year. The first year has permitting and engineering, while the second year has startup and initial operation.

Project cash flows as part of the economic evaluation are shown in Table 15. 


\section{TABLE 27}

HEFPP

Plant Organization Chart

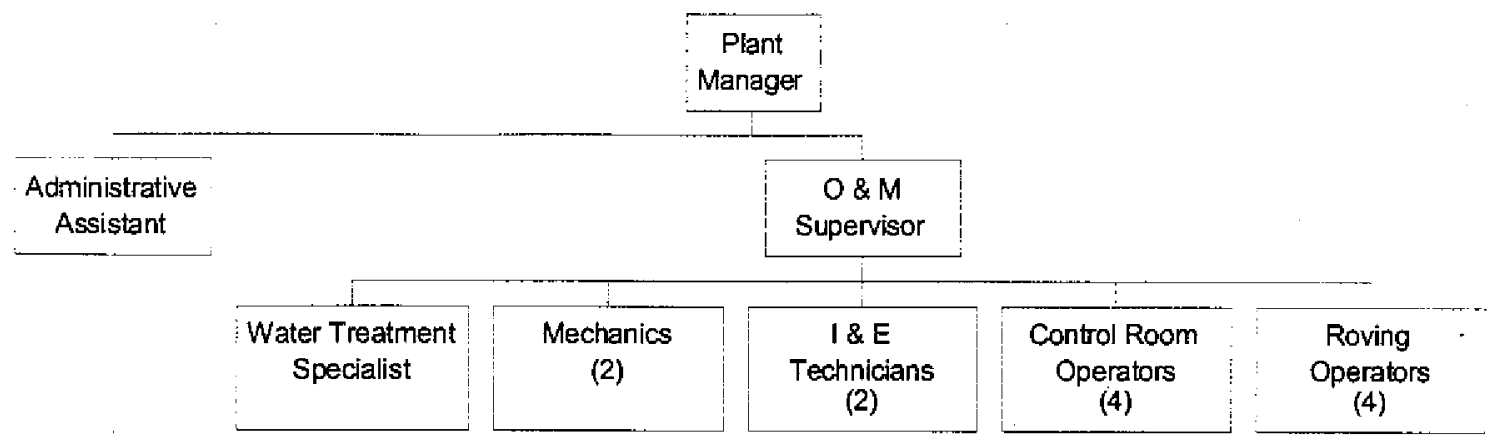

\section{Salaries (1998 Basis)}

Position

Plant Manager

O \& M Supervisor

Administrative Assistant

Water Treatment Specialist

Mechanics

I/E Technicians

Control Room Operator

Roving Operator

TOTAL
Quantity

1

1

1

1

2

2

4

4

16
Unit Annual Salary (\$)

80,000

65,000

25,000

30,000

30,000

40,000

40,000

35,000
Total Annual Salary (\$) 80,000

65,000

25,000

30,000

60,000

80,000

160,000

140,000

640,000 


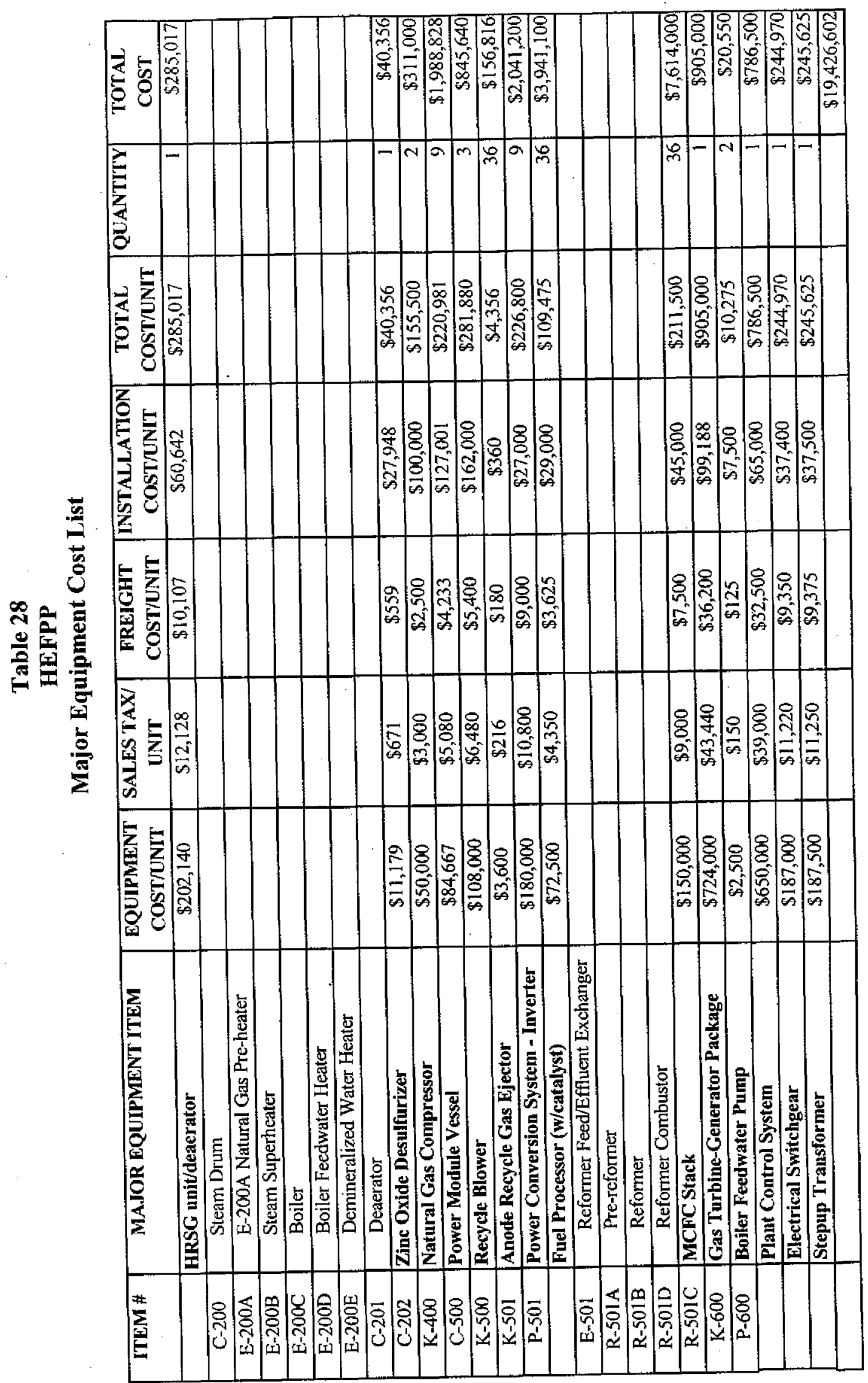

ฐ 


\section{Table 29}

\section{Electric Power Generation Cost}

AREA No PLANT SECTION DESCRIPTION

$$
\begin{array}{lc}
\text { PROCESS } & \text { COST, K\$ w/o } \\
\text { CONT., } \% & \text { CONT. }
\end{array}
$$

\begin{tabular}{|c|c|c|c|}
\hline & HRSG Unit/Deaerator & & 285 \\
\hline & Zinc Oxide Desulfurizer & & 40 \\
\hline & Natural Gas Compressor & & 311 \\
\hline & Power Module Vessel & 5 & 1,989 \\
\hline & Recycle Blower & 10 & 846 \\
\hline & Anode Recycle Gas Ejector & & 157 \\
\hline & Inverter & 10 & 2,041 \\
\hline & Fuel Processor & 10 & 3,941 \\
\hline & MCFC Stack & 10 & 7,614 \\
\hline & Gas Turbine/Generator Package & & 905 \\
\hline & BFW Pump & & 21 \\
\hline & Plant Control System & & 787 \\
\hline & Electrical Switchgear & & 245 \\
\hline & Stepup Transformer & & 246 \\
\hline & Subtotal, Process Plant Cost & & 19,427 \\
\hline General Plant $\mathrm{F}$ & Facilities & & 971 \\
\hline Engineering $\mathrm{Fe}$ & & & 1,457 \\
\hline Process Contin & hgency (Using conntingencies listed above) & & 1,544 \\
\hline Project Conting & gency, $15 \%$ Proc. Plt. \& Gen. Plt. Fac. & & 3,060 \\
\hline & Total Plant Cost & & 26,458 \\
\hline Prepaid Royalt & & & \\
\hline Initial Catalyst & $t$ and Chemical Inventory & & 15 \\
\hline Startup Costs & & & 334 \\
\hline Spare Parts & & & 97 \\
\hline Working Capit & & & 301 \\
\hline Land, & Acres & & 25 \\
\hline & Total Capital Requirement (TCR) & & 27,230 \\
\hline & $3-\mathrm{C}-8$ & $\mathbf{s} / \mathbf{k W}$ & 1,362 \\
\hline
\end{tabular}


Table 30

Annual Operating Costs

\section{COST ITEM}

Natural Gas

Consumable Materials

Demineralized Water
Catalysts \& Chemicals
Fuel Cell Stack Replacement

Disposal Costs (If any)

Plant Labor

Operating Labor (incl. benef.)
QUANTITY

$2609.3 \quad \mathrm{MMBtu} / \mathrm{D}$

37.67

Unit'D

UnitD

Unit/D

Unit/D
See Plant Organization Chart

$\$ \quad 640$

$\$ 291$

$\$ \quad 389$

$\$ 3,983.88$

Total Operating Costs
UNIT \$ PRICE

$\$ 3.00 \quad / \mathrm{MMBtu}$

$\$ 3.00$

/Unit

Unit

/Unit

/Unit

/Unit
COST, KS

$\$ 2,527.46$

$\$ \quad 36.49$

$\$ 100.00$

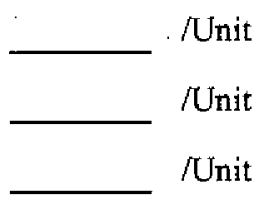

Maintenance Costs

Insurance \& Local Taxes

Royalties

Other Operating Costs

By-Product Credits

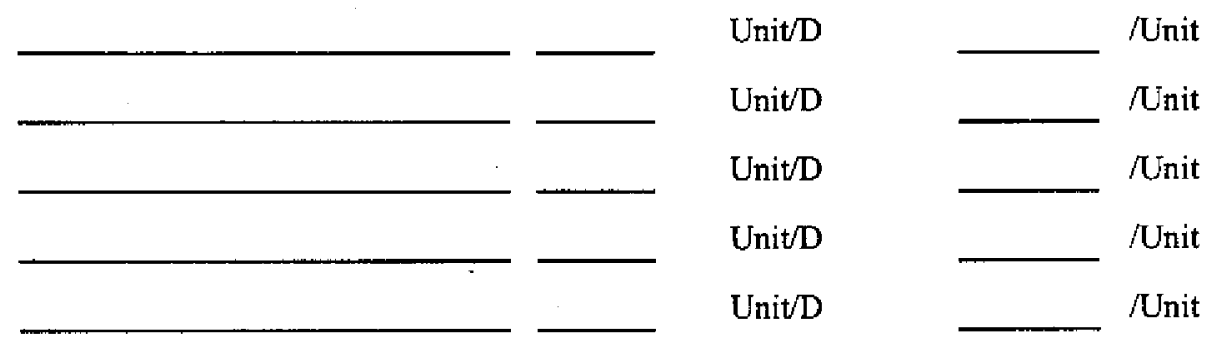

Total By-Product Credits

Net Operating Costs

S $3,983.88$ 


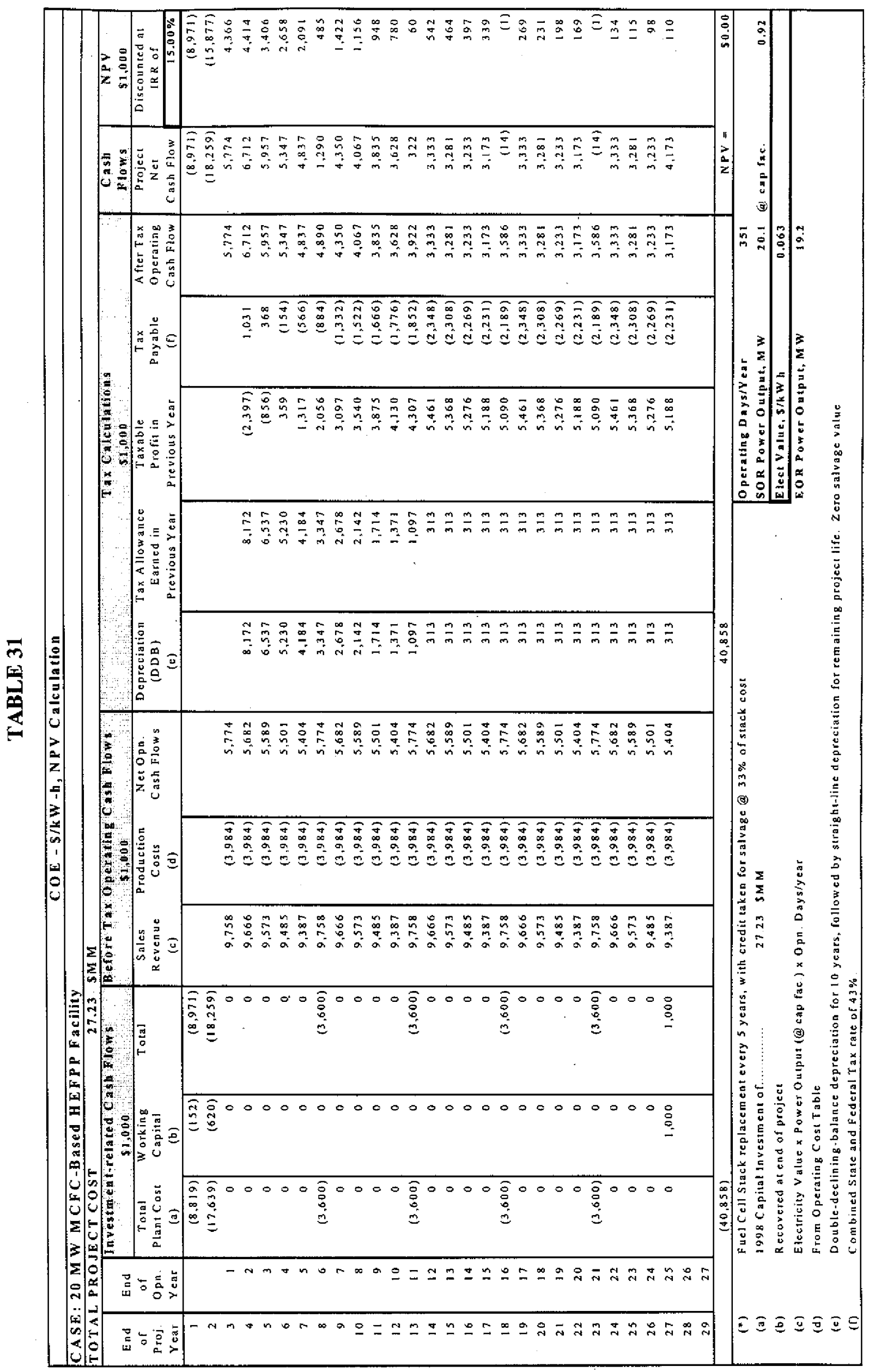

$\frac{9}{6}$ 


\section{C.4, Economic Analysis Results}

The COE for a mature technology $20 \mathrm{MW}$ MCFC-based power plant (for the above design basis and assumptions) is 6.3 cents $/ \mathrm{kW}$-hr. The total project capital requirement for the turnkey facility is $\$ 1362 / \mathrm{kW}$.

In performing the economic analysis for the MCFC-based HEFPP, no cash-flow credits were assigned for the reduced emissions of air pollutants and greenhouse gases characteristics of this type of facility. 


\section{C.5. Comparison of Fuel Cell Power Plant with Competing Technology}

This section compares the MCFC-based HEFPP power plant to similar sized, conventional, fossil-fuel power generation systems. The power generation system selected includes a gas turbine based combined-cycle gas turbine producing $22 \mathrm{MW}$ (16 MW GT, $6 \mathrm{MW}$ steam turbine) gross and $20.2 \mathrm{MW}$ net. Each system is assumed to operate as a base-load unit.

The power plant performance, costs, and COE for a 15\% capital charge rate, for each of these units are compared below.

\section{Power Plant Efficiency}

This performance criteria refers to the efficiency at which each of these power generation systems converts chemical energy in the fuel to net electric power, i.e. the quantity of power available for export to the grid once auxiliary loads have been subtracted.

Combined Cycle Gas Turbine performance figures were obtained from 1998 Gas Turbine World Handbook.

The Table below summarizes the efficiency for each plant.

\section{Plant Efficiency}

\begin{tabular}{rcc}
\hline & CC-GT & HEFPP \\
\hline Efficiency (LHV),\% & 43.3 & 70.1 \\
$\mathrm{~kJ} / \mathrm{kW}-\mathrm{h}$ & 8,314 & 5,134 \\
$\mathrm{kcal} / \mathrm{kW}-\mathrm{h}$ & 1,986 & 1,227 \\
Btu/kW-h & 7,882 & 4,868 \\
& & \\
Nat. Gas, Std.* $\mathrm{M}^{3} / \mathrm{kW}-\mathrm{h}$ & 0.242 & 0.149 \\
\hline
\end{tabular}

${ }^{*} 0^{\circ} \mathrm{C}, 101.3 \mathrm{kPa}$

Clearly, the MCFC-based HEFPP is significantly more efficient at converting chemical energy in fossil-fuel reserves to electric power.

Note: No attempt has been made to increase plant efficiency by including additional heat recovery to low-grade, closed-loop heating cycles, or refrigeration cycles.

\section{Plant Emissions}

Known pollutants associated with fossil-fuel power plants include sulfur oxides $\left(\mathrm{SO}_{\mathrm{x}}\right)$, nitrogen oxides $\left(\mathrm{NO}_{\mathrm{x}}\right)$, carbon monoxide, unburned hydrocarbons, and particulate matter.

NO모

To meet the prevailing emission requirements, gas turbine combined cycle plants must include either low $\mathrm{NO}_{\mathrm{x}}$ burners and/or post-combustion $\mathrm{NO}_{\mathrm{x}}$ reduction technology. Dry, low-NO burners typically achieve $\mathrm{NO}_{x}$ emissions in the range of ppmv. ABB was contacted and the GT- 
35 used in the study presently has a $\mathrm{NO}_{x}$ value of $45 \mathrm{ppm}$. The $25 \mathrm{ppm}$ value will not be available until 2001. The study however has assumed that the $25 \mathrm{ppm} \mathrm{NO}_{\mathrm{x}}$ machine is available for purposes of the study. This is roughly equivalent to 2,500 metric tonnes of $\mathrm{NO}_{\mathrm{x}}$ emissions over the 25-year life of the $22 \mathrm{MW} \mathrm{CC}$-GT plant. Further reductions in $\mathrm{NO}_{\mathrm{x}}$ emissions can be achieved by including best available control technology (BACT) such as a selective catalytic reduction unit (SCR), or catalytic control technology like $\mathrm{SCONO}_{\mathrm{x}}^{\mathrm{TM}}$, which has recently pushed the lowest achievable emissions rate for $\mathrm{NO}_{\mathrm{x}}$ to $2-3 \mathrm{ppmv}$. Emission of 3 ppmv $\mathrm{NO}_{\mathrm{x}}$ over the plant life is equivalent to emitting 320 metric tonnes of $\mathrm{NO}_{\mathrm{x}}$. Typical performance for SCRs is in the region of 9 ppmv $\mathrm{NO}_{x}$. By using the SCR technology, unreacted ammonia release into the atmosphere requires monitoring in the exhaust stack. Other pollutants such as $\mathrm{NO}_{\mathrm{x}}, \mathrm{CO}$, and unburned hydrocarbons must also be monitored by a continuous emissions monitoring system. This system requires a significant amount of maintenance and utilizes a significant amount of calibration gases for proper operation.

$\mathrm{NO}_{\mathrm{x}}$ production in the HEFPP is expected to be extremely low. South Coast Air Quality Management District (SCAQMD)(located in the Los Angeles area) tests for Phosphoric Acid Fuel Cell (PAFC) atmospheric emissions, measured $\mathrm{NO}_{\mathrm{x}}$ emissions as $<1$ ppmv. MCFCs are expected to achieve even lower $\mathrm{NO}_{\mathrm{x}}$ emission levels, since less combustion is needed to provide the heat for the fuel processing step. In addition, since all of the gas from the fuel processor's catalytic combustor passes through the MCFC cathode compartment, which is an excellent " $\mathrm{NO}_{\mathrm{x}}$ scrubber" , the emission of $\mathrm{NO}_{\mathrm{x}}$ from the stack should be negligible. $\mathrm{NO}_{\mathrm{x}}$ measurements taken by IHI on their MCFC stack were undetectable on equipment with a 1 ppmv lower detectable limit.

At 1 ppmv $\mathrm{NO}_{\mathrm{x}}$ emission, the quantity of $\mathrm{NO}_{\mathrm{x}}$ emitted over the 25-year life of the HEFPP would be 23 metric tonnes.

It is important to emphasize that combustion turbine based power plants, where the turbine combustor continuously fires fuel to sustain the cycle, cannot yet achieve the $\mathrm{NO}_{\mathrm{x}}$ emission performance of a MCFC-based power plant.

The Table below illustrates the estimated $\mathrm{NO}_{\mathrm{x}}$ emissions from each plant.

NO Emissions

\begin{tabular}{|c|c|c|}
\hline & $\mathrm{CC}-\mathrm{GT}$ & $\overline{\text { HEFPP }}$ \\
\hline $\mathrm{NO}_{\mathrm{x}}$ Emission (low NO $\mathrm{N}_{\mathrm{x}}$ bnr. + SCR) & $3 \mathrm{ppmv}$ & $<1 \mathrm{ppm}$ \\
\hline $\mathrm{NO}_{\mathrm{x}}$ emitted over life of plant, $\mathrm{MT}$ & 316 & $<23$ \\
\hline
\end{tabular}

$\underline{\mathbf{S O}_{\mathrm{x}}}$

The amount of $\mathrm{SO}_{x}$ generated depends on the quantity of fuel combusted and its sulfur content. Since the MCFC-based HEFPP 1) desulfurizes its fuel feedstock, 2) has a higher natural-gasconversion efficiency, 3) will capture desulfurization trace sulfur ( $<0.1 \mathrm{ppmv})$ in the prereforming/reforming section, and 4) does not fire the gas turbine combustor during normal

\footnotetext{
${ }^{4}$ A.J. Appelby, Characteristics of Fuel Cell Systems.
} 
operation, the amount of sulfur emitted from the plant can be considered negligible, or insignificant.

The Table below illustrates the estimated $\mathrm{SO}_{\mathrm{x}}$ emissions from each plant.

$\mathrm{SO}_{\mathbf{x}}$ Emissions

CC-GT HEFPP

\begin{tabular}{lll}
$\mathrm{SO}_{\mathrm{x}}$ emitted over life of plant, MT & 12.2 & $<0.2$ \\
\hline
\end{tabular}

\section{$\underline{\mathrm{CO}_{2}}$}

There is increasing support being given to the viewpoint that the continued emission of so-called greenhouse gases is causing changes to the global climate. Human-based activities leading to the emission of carbon dioxide, methane, chlor-fluorocarbons, and other gases are believed to be the main contributors to the climate change. ${ }^{5}$ At the Kyoto conference, Annex 1 countries agreed to an average reduction of $5.2 \%$ in greenhouse gas emissions by the period $2008-2012$.

By virtue of its superior fuel conversion efficiency, the MCFC-based HEFPP has one of the lowest $\mathrm{CO}_{2}$ emissions rating of any commercial, or near-commercial, fossil-fuelled power plants.

The Table below illustrates the estimated $\mathrm{CO}_{2}$ emissions from each plant.

$\mathrm{CO}_{2}$ Emissions

\begin{tabular}{lrr}
\hline & CC-GT & HEFFP \\
\hline $\mathrm{CO}_{2}$ emitted over life of plant, MT & $2.1 \times 10^{6}$ & $1.1 \times 10^{6}$ \\
\hline
\end{tabular}

As summarized in the three tables above, the MCFC-based HEFPP emits significantly less air pollutants and greenhouse gases than the competing fossil-fuel power generation systems.

\section{Power Plant Economic Analysis}

\section{Cost of Electricity}

The cost of producing electric power for each system is summarized below. The basis for comparison is:-natural gas price $\$ 3.00 / \mathrm{MMBtu}$ (HHV), capital charge rate $15 \%$, capacity factor $92 \%$, and plant life 25 -years.

The COE comparison is summarized below, while detailed capital and operating costs and the NPV analyses for the gas turbine combined cycle facilities are presented in Tables 32, 33, and 34.

The costs for the gas turbine combined cycle were obtained from recent power plant publications. Costs for SCR NOx control systems, plant control systems, and continuous

\footnotetext{
${ }^{5} \mathrm{~K}$. Thambimuthu and P. Freuund IEA Greenhouse Gas R\&D Programme.
} 
emissions monitoring systems were added to the gas turbine simple cycle and combined cycle projects. Project line-item costs below the PPC (engineering fees, project contingency, working capital, spare parts, maintenance, local taxes and insurance, etc.) were applied at the same rates as used for the HEFPP capital and operating cost estimates. No process equipment contingencies were applied to the gas turbine or steam turbine cycles - although a $10 \%$ contingency was applied to the estimated cost for the SCR. Based on discussions with $\mathrm{ABB}$, the entire plant would have a major overhaul covering the gas turbine generator, steam turbine generator, HRSG, cooling tower, condenser and other balance of plant equipment every five years. ABB recommended that the five year overhaul costs should be based on $\$ 2.00 / \mathrm{MWh}$ of operation. This major overhaul would last four weeks and would impact the sales revenues for the overhaul years. It should be noted that the gas turbine will have to come off line for ten hours for water washing the compressor section every two months. Power plant output also degrades approximately one half percent per year between plant major overhauls due to gas turbine and steam turbine performance degradation. Catalyst and chemical costs will be significantly higher for the combined cycle plant due to plant lube oils, cooling tower water treatment chemicals, CEM calibration gases, gas turbine washing fluids and SCR ammonia.

COE Comparison

\begin{tabular}{|c|c|c|}
\hline & CC-GT & HEFPP** \\
\hline Total Plant Investment, \$MM & 23.2 & 27.2 \\
\hline$\$ / \mathrm{kW}$ & 1161 & 1362 \\
\hline $\begin{array}{l}\text { Annual Operating Costs, } \$ M M \\
\text { (Based on } \$ 3.00 / \mathrm{MMBtu} \text { gas) }\end{array}$ & 6.13 & 3.98 \\
\hline $\mathrm{COE}^{*}$ for $\$ 1.50 / \mathrm{MMBtu}$ gas, $\phi / \mathrm{kW}-\mathrm{h}$ & 5.6 & 5.4 \\
\hline $\mathrm{COE}^{*}$, for $\$ 3.00 / \mathrm{MMBtu}$ gas, $\phi / \mathrm{kW}-\mathrm{h}$ & 7.1 & 6.3 \\
\hline $\mathrm{COE}^{*}$, for $\$ 5.00 / \mathrm{MMBtu}$ gas, $\phi \mathrm{kW}-\mathrm{h}$ & 9.1 & 7.4 \\
\hline
\end{tabular}

* -after depreciation and State and Federal taxes.

** -no financial credits have been taken for the environmental benefits of the MCFC-based HEFPP. 
TABLE 32

Combined Cycle Gas Turbine

Power Plant Capital Cost

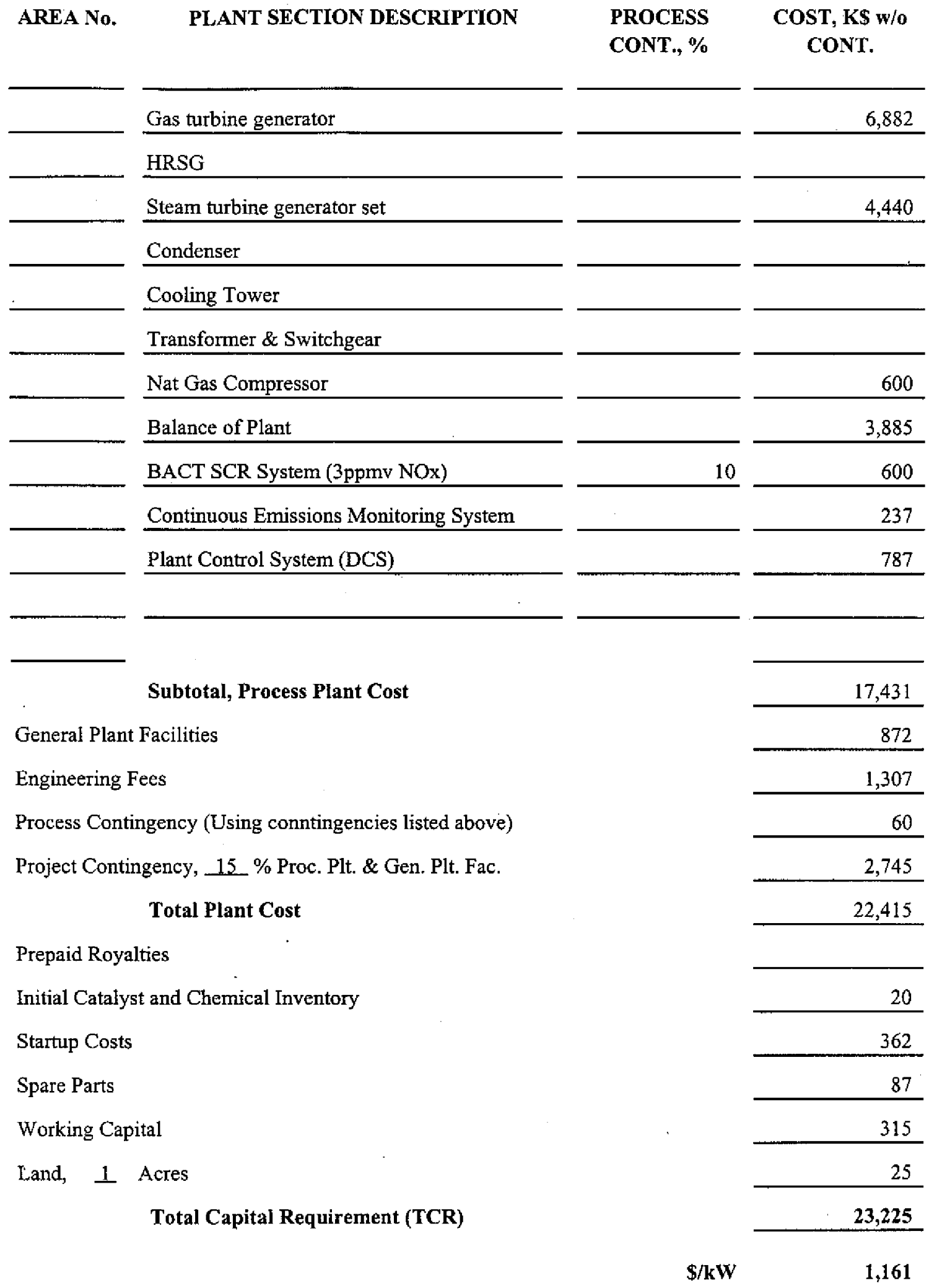


TABLE 33

Combined Cycle Gas Turbine

Annual Operating Costs

COST ITEM

Natural Gas Fuel Type

Consumable Materials

Demineralized Water

Catalysts \& Chemicals

Turbine Blade Replacement

Disposal Costs (If any)

Plant Labor

Operating Labor (incl. benef.) Supervision \& Clerical

Maintenance Costs

Insurance \& Local Taxes

Royalties

Other Operating Costs

Total Operating Costs

QUANTITY

MMBtu/D
UNIT \$ PRICE ANNUAL

COST, K\$

$\$ 3.00$

/MMBtu

$\$$

4,639

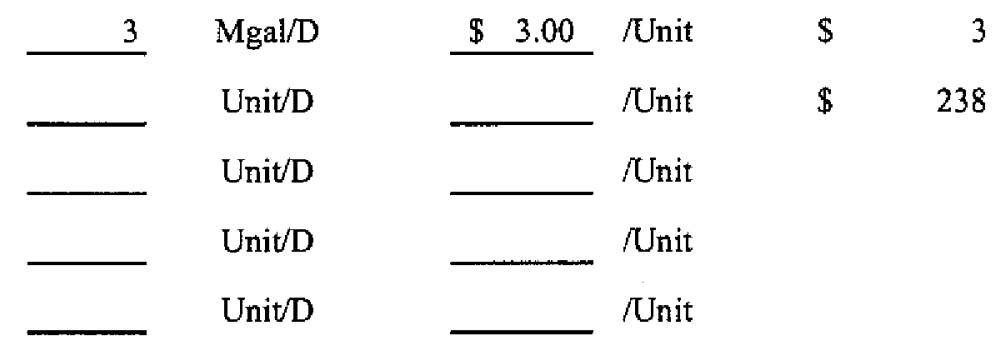

Operating Staff Number and Costs Similar to HEFPP

$\$ 640$

$\$ 261$

$\$ \quad 349$

$\$ \quad 6,129$

By-Product Credits

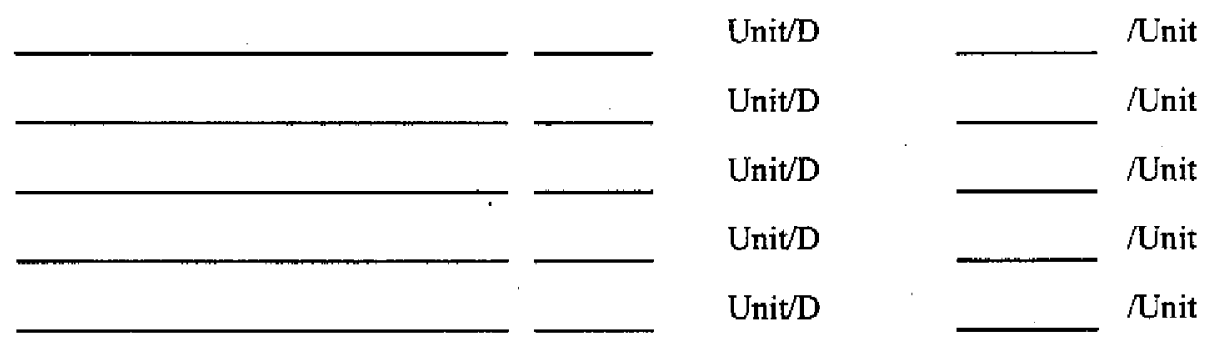

Total By-Product Credits

Net Operating Costs

\$ $\quad 6,129$ 


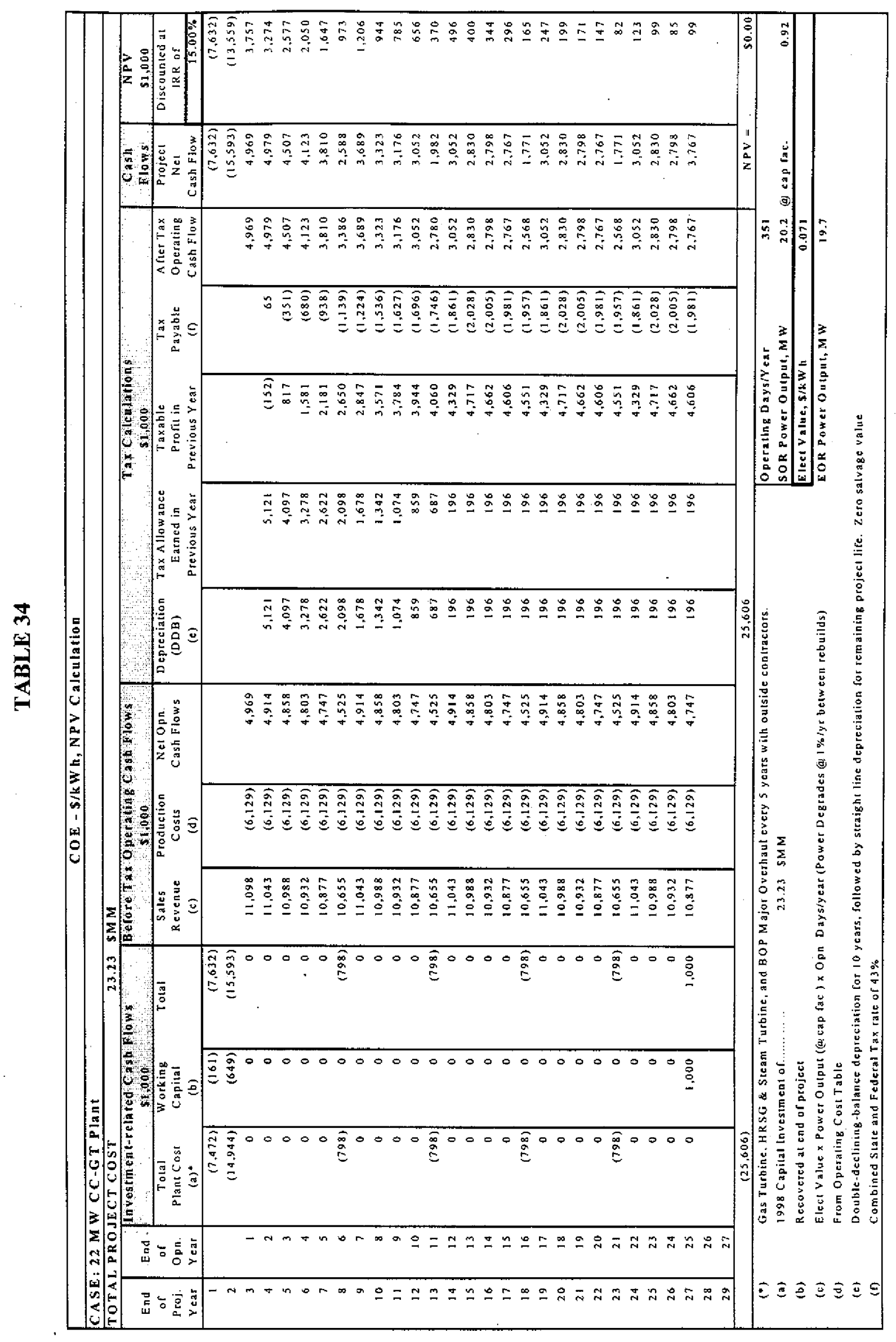

$\frac{\infty}{1}$ 


\section{CONCLUSION}




\section{CONCLUSION}

This study has confirmed that Pressurized Molten Carbonate Fuel Cell technology can be combined with gas turbine generator technology to produce a power plant with $70 \%$ low heating value efficiency when utilizing natural gas as a fuel. The study also confirmed that the HEFPP concept produced significantly lower 6.3 cents $/ \mathrm{kWh}$ cost of electricity when compared to a similar sized gas turbine combined cycle plant with a $7.1 \mathrm{cents} / \mathrm{kWh}$ cost of electricity based on a natural gas fuel cost of $\$ 3.00 / \mathrm{MMBtu}$. The HEFPP cost of electricity sensitivity to fuel cost was investigated with fuels ranging from $\$ 1.50$ to $\$ 5.00$ per MMBtu. In all cases the HEFPP concept was considerably cheaper in cost of electricity than a gas turbine combined cycle plant of similar size.

This study has assumed that investments in the HEFPP components will be made to drive the component costs down and to eliminate the technical issues. Specific components requiring further investment and development time include fuel cell stacks, gas turbine generator, recycle blower, power.module vessels, inverter, reformer, and plant control philosophy.

Most of the development items on the molten carbonate fuel cell are already being addressed under M-C Power's Process Design Improvement program funded by DOE.

With the HEFPP concept, the fuel cell will have design and development issues related to operation at $610 \mathrm{kPa}$. The gas compositions and flow rate will affect pressure drop and cell performance. The higher pressure may result in higher output per stack because the internal manifolds will shrink and the active area increase. Bench, small area, and full area stack performance testing will be required to confirm predicted current densities and voltages with actual gas compositions at the $610 \mathrm{kPa}$ pressure. Endurance testing of fuel cell stacks will also be required to determine if pressure has an effect on stack components. Series connections for four cells will also have to be designed and tested.

Many of the turbine generator components are of new design or must be scaled up or down to meet the specific application. These components will require engineering, fabrication development, and prototype testing prior to use in the power plant. Specific examples include the active magnetic bearings, direct drive alternator, turbine generator controls, and the power conditioner.

The recycle blower temperature problems are being worked through at the Miramar plant, but the shaft sealing solutions at a pressure of $606 \mathrm{kPa}$ must be developed and tested. The limited number of manufacturers with experience at this operating pressure also presents a problem.

The power module vessel will require some design work to conquer the design constraints imposed both internally and externally. In this case, Bechtel National, a vessel fabricator, and the module fabricator will have to work closely to develop the design. Input will be required from M-C Power and IHI for the fuel cell and reformer installation/operation/maintenance issues, respectively. 
The inverter design and development issues appear much more straightforward than the other components mentioned above. The most important inverter design challenges include the efficiency improvement, technology selection, product repackaging, and performance testing issues. Most of the issues can be resolved by a contractual relationship with an inverter manufacturer. Once the product is developed and tested successfully, the inverter manufacturer may have a significant competitive advantage in technology and product introduction over rivals who have not developed or tested products.

The reformer design will require some development work to accommodate the higher operating pressure of $610 \mathrm{kPa}$. At higher pressures, the specific volume of the gases is smaller which will reduce the pipe diameter and plate spacing. The higher pressure will however require thicker pipe materials to be used. Some development work and testing will also be required to meet the catalyst life goal of 80,000 hours or ten years.

The overall plant control concept also will require refinement. Integration of the turbine generator and multiple fuel cell inverters will require design work. Strategies for response to electrical system transients such as loss of electric grid, ground faults in a single phase or neutral must be developed. Modeling work will be required to determine HEFPP capabilities for load following, load shedding, and plant turndown.

The plant control system will also have to integrate the individual component control systems for the gas turbine generator and inverter with the other equipment in the plant.

Finally, the technical challenges mentioned above are not insurmountable and can be overcome with time and targeted funding. Clearly, much of the technology exists today and has been proven on a smaller scale by M-C Power at Miramar and in the future will be proven by M-C Power's $450 \mathrm{~kW}$ class molten carbonate fuel cell hybrid power plant using a micro gas turbine generator. The HEFPP concept is feasible and predicted performance levels can be met. This study has presented the plans and approaches required to solve the performance, life and cost issues by 2010 or sooner. The proposed HEFPP concept will produce a low cost of energy and environmentally friendly plant with significantly lower emissions than the gas turbine generator combined cycle plants of today. 